Supporting Information

\title{
Mapping and Exploiting the Promiscuity of OxyB toward Biocatalytic Production of Vancomycin Aglycone Variants
}

Clarissa C. Fornerist, ${ }^{t,}$ Andy K. L. Nguy ${ }^{t, \&}$, Mohammad R. Seyedsayamdost ${ }^{t, \neq}, *$

Departments of Chemistry ${ }^{\dagger}$ and Molecular Biology ${ }^{\ddagger}$, Princeton University, Princeton, NJ 08544

\footnotetext{
${ }^{\&}$ These authors contributed equally

*Email: mrseyed@princeton.edu
} 


\section{Materials and strains.}

Amycolatopsis orientalis DSM40040 was obtained from the DSMZ. LB broth, Terrific Broth and LB agar were purchased from Becton Dickinson. All antibiotics, IPTG, PMSF, lysozyme, $\beta$ ME, Sephadex G-25, COMU, NEt 3 , DIPEA, TIS, DBU, TFA, $N$-methylmorpholine, hydrazine monohydrate, $\mathrm{NaNO}_{2}$, coenzyme A trilithium salt, glucose-6-phosphate dehydrogenase, glucose-6-phosphate, and other components necessary for biochemical assays were obtained from Sigma-Aldrich. Nickel affinity resin and DNase I were purchased from Clontech. Restriction enzymes, T4 DNA ligase, proofreading Q5 DNA polymerase, and the corresponding buffers were purchased from New England Biolabs. PCR reactions were routinely carried out in Failsafe buffer G (Epicentre). Commercially available Fmoc- and side chain-protected amino acids, 2-chlorotrityl chloride resin and other components for solid-phase peptide synthesis were purchased from Novabiochem/EMD Millipore, Sigma-Aldrich and ChemImpex.

Reactions were monitored by thin layer chromatography (TLC) carried out on $250 \mu \mathrm{m}$ Merck silica gel plates (60 F254) containing a fluorescent indicator (254 nm). Visualization of the developed TLC plate was performed by irradiation with UV light. Standard NMR spectra were acquired at the Princeton University Department of Chemistry Core Facilities. ${ }^{1} \mathrm{H}$ spectra were recorded in the TCI cryoprobe of a Bruker Avance III $500 \mathrm{MHz}$ spectrometer. Data for ${ }^{1} \mathrm{H}$ spectra are reported as follows: chemical shift $(\delta \mathrm{ppm})$, multiplicity $(\mathrm{s}=$ singlet, $\mathrm{d}=$ doublet, $\mathrm{t}=$ triplet, $\mathrm{q}$ $=$ quartet, $\mathrm{m}=$ multiplet, $\mathrm{b}=$ broad $)$, integration, coupling constant $(\mathrm{Hz})$ and assignment. ${ }^{13} \mathrm{C} \mathrm{NMR}$ spectra were also recorded in a Bruker Avance III $500 \mathrm{MHz}(126 \mathrm{MHz})$ spectrometer. Reported below are ${ }^{13} \mathrm{C}$ chemical shifts.

For structural elucidation of enzymatic reaction products, 1D/2D NMR spectra were acquired at the Princeton University Department of Chemistry NMR Facilities on an A8 Avance III HD 800-MHz NMR spectrometer (Bruker) with a triple resonance cryoprobe. The NMR samples were prepared in $\left(\mathrm{CD}_{3}\right)_{2} \mathrm{SO}$.

Expression and purification of OxyB, OxyA, OxyC, PCP7-X, Fd, FdR, Sfp R4-4. OxyB, OxyA, OxyC and PCP7-X from Amycolatopsis orientalis DSM 40040 were expressed and purified as previously described. ${ }^{1,2}$ Spinach ferredoxin $(\mathrm{Fd})$, E. coli ferredoxin reductase $(\mathrm{FdR})$, and Spf R4-4 from B. subtilis (codon-optimized, K28E/T44E/C77Y triple mutant of phosphopantetheinyl transferase) were expressed and purified as previously described., ${ }^{1,3}$ 


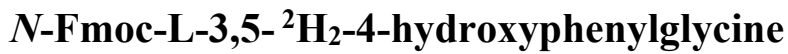<smiles>[2H]c1cc(C(NC(C)=O)C(=O)O)cc([2H])c1O</smiles>

A 50-mL Schlenk flask equipped with a stir bar and rubber septum was charged with L-4hydroxyphenylglycine $(600 \mathrm{mg}, 3.60 \mathrm{mmol})$, potassium tetrachloroplatinate(II) (372 $\mathrm{mg}, 0.90$ mmol, 0.25 equiv.) and $\mathrm{DCl}-\mathrm{D}_{2} \mathrm{O}(1 \mathrm{~N}, 15 \mathrm{~mL})$. The reaction mixture was evacuated and refilled with $\mathrm{N}_{2}$ five times to remove oxygen and stirred under reflux for $24 \mathrm{~h}$. After cooling to room temperature, the reaction mixture was concentrated, dissolved in $\mathrm{MeOH}(45 \mathrm{~mL})$ and filtered through a Buchner funnel to remove the catalyst. The filtrate was concentrated, and the hydrochloride amino acid was obtained as a colorless powder (600 mg, $3.60 \mathrm{mmol}$, quantitative yield). ${ }^{1} \mathrm{H}$ NMR (500 MHz, $\left.\left(\mathrm{CD}_{3}\right)_{2} \mathrm{SO}\right): \delta 8.73(\mathrm{~d}, J=5.2 \mathrm{~Hz}, 2 \mathrm{H}), 7.28(\mathrm{~s}, 2 \mathrm{H}), 4.93$ (t, $J=5.2$ $\mathrm{Hz}, 1 \mathrm{H}) . \mathrm{N}$-Fmoc protection of $\mathrm{L}-3,5-{ }^{2} \mathrm{H}_{2}-4$-hydroxyphenylglycine was carried out using the same procedure as previously described. (2) A colorless powder was obtained (1.2 g, $3.24 \mathrm{mmol}, 90 \%$ yield). ${ }^{1} \mathrm{H}$ NMR (500 MHz, $\left.\left(\mathrm{CD}_{3}\right)_{2} \mathrm{SO}\right) \delta 12.69(\mathrm{~s}, 1 \mathrm{H}), 9.47(\mathrm{~s}, 1 \mathrm{H}), 8.06$ (d, J=7.7 Hz, 1H), 7.89 $(\mathrm{d}, J=7.5 \mathrm{~Hz}, 2 \mathrm{H}), 7.75(\mathrm{~d}, J=7.5 \mathrm{~Hz}, 2 \mathrm{H}), 7.41$ (t, $J=7.4 \mathrm{~Hz}, 2 \mathrm{H}), 7.31$ (q, $J=7.9 \mathrm{~Hz}, 2 \mathrm{H})$, $7.21(\mathrm{~s}, 2 \mathrm{H}), 5.01(\mathrm{~d}, J=7.8 \mathrm{~Hz}, 1 \mathrm{H}), 4.24(\mathrm{~m}, 4 \mathrm{H})$.

\section{N-Fmoc-L-3,5-2 ${ }^{2}{ }_{2}$-homotyrosine}

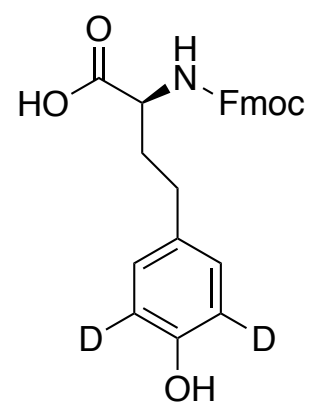

L-3,5- ${ }^{2} \mathrm{H}_{2}$-homotyrosine was prepared from L-homotyrosine by the same procedure outlined for the synthesis of L-3,5- ${ }^{2} \mathrm{H}_{2}-4$-hydroxyphenylglycine and isolated as a colorless powder. ${ }^{1} \mathrm{H}$ NMR $\left(500 \mathrm{MHz},\left(\mathrm{CD}_{3}\right)_{2} \mathrm{SO}\right) \delta 8.62(\mathrm{~d}, 5.5 \mathrm{~Hz}, 2 \mathrm{H}), 7.07(\mathrm{~s}, 2 \mathrm{H}), 3.94-3.86(\mathrm{~m}, 1 \mathrm{H}), 3.22(\mathrm{~s}$, $3 \mathrm{H}), 2.71(\mathrm{~m}, 1 \mathrm{H}), 2.08(\mathrm{~m}, 1 \mathrm{H})$ (other $\beta$-protons are obscured by solvent peaks). $N$-Fmoc protection was carried out without intermediate purification and following previously described 
procedure. ${ }^{2}$ A colorless powder was obtained (1.05 g, $2.5 \mathrm{mmol}, 69 \%$ yield over two steps). ${ }^{1} \mathrm{H}$ NMR (500 MHz, $\left.\left(\mathrm{CD}_{3}\right)_{2} \mathrm{SO}\right) \delta 12.56(\mathrm{~s}, 1 \mathrm{H}), 9.15(\mathrm{~s}, 1 \mathrm{H}), 7.91(\mathrm{~d}, J=7.6 \mathrm{~Hz}, 2 \mathrm{H}), 7.78-7.71$ (m, 2H), 7.43 (t, $J=7.5 \mathrm{~Hz}, 2 \mathrm{H}), 7.34$ (td, $J=7.4,3.2 \mathrm{~Hz}, 2 \mathrm{H}), 6.97$ (s, 2H), $4.36-4.23$ (m, 4H), $3.87(\mathrm{~m}, 1 \mathrm{H}), 2.56(\mathrm{~m}, 1 \mathrm{H}), 1.88(\mathrm{~m}, 2 \mathrm{H}) .{ }^{13} \mathrm{C} \mathrm{NMR}\left(126 \mathrm{MHz},\left(\mathrm{CD}_{3}\right)_{2} \mathrm{SO}\right) \delta 174.52,156.67$, $155.85,144.35,144.28,141.22,131.42,129.60,128.12$, 127.55, 125.77, 125.74, 120.60, 66.02, $60.24,47.15,33.35,31.18$.

\section{$\mathrm{N}$-Boc-4-CD $-\mathrm{L}-$ phenylalanine methyl ester}

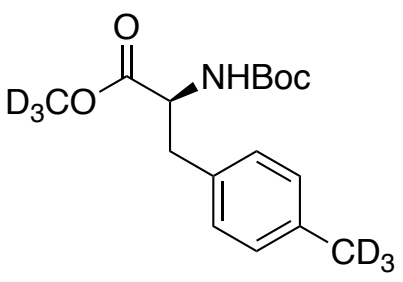

A 100-mL round bottom flask equipped with a stir bar, reflux condenser, rubber septum and $\mathrm{N}_{2}$ inlet was charged with $N$-Boc-4-BPin-L-phenylalanine (1 g, $\left.2.56 \mathrm{mmol}\right)$, potassium carbonate (1.77 g, $12.8 \mathrm{mmol}, 5.0$ equivalents), iodomethane-d3 (2.2 g, $15.3 \mathrm{mmol}, 6.0$ equivalents), 1,4-dioxane $(44.8 \mathrm{~mL})$ and water $(6.4 \mathrm{~mL})$. The resulting mixture was degassed and $\mathrm{Pd}(\mathrm{dppf})_{2} \mathrm{Cl}_{2}(93 \mathrm{mg}, 0.128 \mathrm{mmol}, 5 \mathrm{~mol} \%$ ) was added. After stirring under reflux overnight, the reaction mixture was cooled to room temperature and diluted with $7.7 \mathrm{~mL}$ of methanol. 1,4dioxane was removed by rotatory evaporation and the resulting solution was extracted into EtOAc $\left(3 \times 20 \mathrm{~mL}\right.$ ). The organic layers were combined, dried over $\mathrm{Na}_{2} \mathrm{SO}_{4}$, filtered and concentrated to yield a brown oil. The desired product was purified by preparative HPLC in a Phenomenex Luna $\mathrm{C} 18(5 \mu, 250 \times 21.2 \mathrm{~mm})$ equilibrated with $15 \% \mathrm{MeCN}$; product was eluted with a gradient of $60-100 \% \mathrm{MeCN}$ over $15 \mathrm{~min}$. A colorless oil was isolated (243 $\mathrm{mg}, 0.81 \mathrm{mmol}, 32 \%$ yield). ${ }^{1}$ NMR (500 MHz, methanol- $\left.d_{4}\right) \delta 7.14-7.04(\mathrm{~m}, 4 \mathrm{H}), 4.31(\mathrm{~m}, 1 \mathrm{H}), 3.04(\mathrm{dd}, J=13.8,5.7 \mathrm{~Hz}$, $1 \mathrm{H}), 2.85(\mathrm{dd}, J=13.9,8.8 \mathrm{~Hz}, 1 \mathrm{H}), 1.38(\mathrm{~s}, 9 \mathrm{H}) .{ }^{13} \mathrm{C}$ NMR $\left(126 \mathrm{MHz}\right.$, methanol- $\left.d_{4}\right) \delta 174.30$, $157.8,137.3,135.2,130.1,130.080 .6,56.6,38.3,28.6$. 


\section{4-CD $-L-p h e n y l a l a n i n e$}

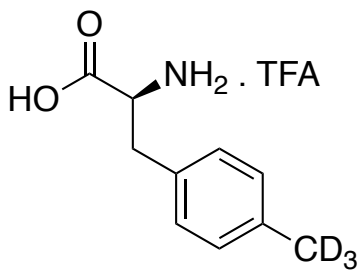

$\mathrm{N}$-Boc-4-CD 3 -L-phenylalanine methyl ester $(250 \mathrm{mg}, 0.83 \mathrm{mmol})$ was dissolved in a 1:1 water/THF mixture $(8 \mathrm{~mL})$ and cooled in an ice/water bath. $\mathrm{LiOH}(105 \mathrm{mg}, 2.5 \mathrm{mmol}, 3.0$ equivalents) was added to the solution and the reaction mixture was stirred for 5 hours. Subsequently, the mixture's $\mathrm{pH}$ was adjusted to 2 with $1 \mathrm{~N} \mathrm{HCl}$ and THF was removed by rotatory evaporation. The resulting solution was extracted with EtOAc $(3 \times 10 \mathrm{~mL})$ and the combined organic layers were dried over $\mathrm{Na}_{2} \mathrm{SO}_{4}$, filtered and concentrated. The resulting colorless solid was dissolved in DCM (5.4 mL), cooled in an ice/water bath, charged with TFA (5.4 mL) and stirred for 3 hours. DCM and TFA were removed by rotatory evaporation and a clear oil was obtained (208 mg, $0.74 \mathrm{mmol}, 91 \%$ yield). ${ }^{1} \mathrm{H}$ NMR (500 MHz, Methanol- $\left.d_{4}\right) \delta 7.18(\mathrm{~m}, 4 \mathrm{H}), 4.21$ (dd, $J=$ 7.9, $5.3 \mathrm{~Hz}, 1 \mathrm{H}), 3.27(\mathrm{dd}, J=14.5,5.3 \mathrm{~Hz}, 1 \mathrm{H}), 3.10(\mathrm{dd}, J=14.6,7.9 \mathrm{~Hz}, 1 \mathrm{H}) .{ }^{13} \mathrm{C}$ NMR $(126$ $\mathrm{MHz}$, methanol- $\left.d_{4}\right) \delta 171.3138 .7,132.4,130.8,130.3,55.2,37.0,27.7$.

\section{$N$-Fmoc-4-CD3-L-phenylalanine}

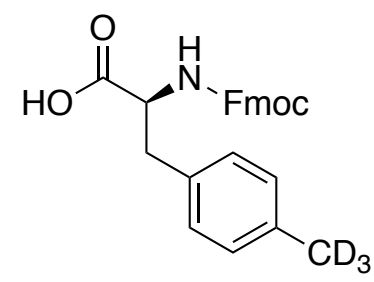

$\mathrm{N}$-Fmoc protection of 4-CD 3 -L-phenylalanine was performed as outlined previously. A colorless powder was isolated (286 mg, $0.71 \mathrm{mmol}, 86 \%$ yield). ${ }^{1} \mathrm{H}$ NMR (500 MHz, Methanol$\left.d_{4}\right) \delta 7.79(\mathrm{~d}, J=7.5 \mathrm{~Hz}, 2 \mathrm{H}), 7.59(\mathrm{t}, J=7.0 \mathrm{~Hz}, 2 \mathrm{H}), 7.41-7.35(\mathrm{~m}, 2 \mathrm{H}), 7.29$ (ddd, $J=9.1,7.5$, $1.2 \mathrm{~Hz}, 2 \mathrm{H}), 7.12(\mathrm{~d}, J=8.1 \mathrm{~Hz}, 2 \mathrm{H}), 7.07$ (d, $J=8.1 \mathrm{~Hz}, 2 \mathrm{H}), 4.40$ (dd, $J=9.6,4.8 \mathrm{~Hz}, 1 \mathrm{H}), 4.30$ $(\mathrm{dd}, J=10.5,7.0 \mathrm{~Hz}, 1 \mathrm{H}), 4.20(\mathrm{dd}, J=10.3,7.2 \mathrm{~Hz}, 1 \mathrm{H}), 4.15$ (t, $J=7.1 \mathrm{~Hz}, 1 \mathrm{H}), 3.17$ (dd, $J=$ 14.0, $4.8 \mathrm{~Hz}, 1 \mathrm{H}), 2.89(\mathrm{dd}, J=13.9,9.6 \mathrm{~Hz}, 1 \mathrm{H}) .{ }^{13} \mathrm{C} \mathrm{NMR}\left(126 \mathrm{MHz}\right.$, methanol- $\left.d_{4}\right) \delta 173.82$, $156.98,143.82$, 141.14, 134.13, 128.79, 128.66, 127.34, 126.73, 124.96, 124.84, 119.48, 119.45, $66.60,55.46,36.76,24.88$. 


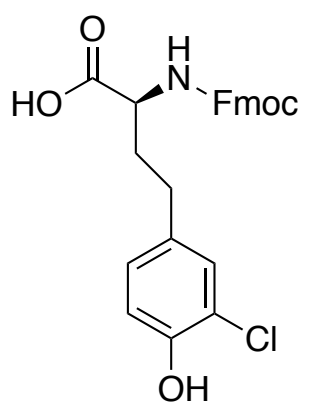

\section{N-Fmoc-3-Cl-L-homotyrosine}

A $25-\mathrm{mL}$ round bottom flask was charged with homotyrosine (200 mg, $0.72 \mathrm{mmol}), \mathrm{AcOH}$ $(1 \mathrm{~mL})$ and $\mathrm{SO}_{2} \mathrm{Cl}_{2}$ (106 mg, $0.79 \mathrm{mmmol}, 1.10$ equivalents). The resulting slurry was stirred at room temperature for 3 hours, filtered, washed with AcOH and purified via preparative HPLC. Multiple injections on a Phenomenex Luna C18 (5 $\mu, 250 \times 21.2 \mathrm{~mm})$ equilibrated with 5\% MeCN were performed and the product was eluted with a gradient of 5-42\% MeCN over 20 min. A colorless solid was isolated (107 mg, $0.39 \mathrm{mmol}, 54 \%$ yield) ${ }^{1} \mathrm{H}$ NMR (500 MHz, $\left.\left(\mathrm{CD}_{3}\right)_{2} \mathrm{SO}\right) \delta$ $10.02(\mathrm{~s}, 1 \mathrm{H}), 7.56(\mathrm{~s}, 2 \mathrm{H}), 7.31(\mathrm{~s}, 1 \mathrm{H}), 7.01(\mathrm{~d}, J=8.1 \mathrm{~Hz}, 1 \mathrm{H}), 6.87(\mathrm{~d}, J=8.2 \mathrm{~Hz}, 1 \mathrm{H}), 3.07$ (s, 1H), $1.93(\mathrm{~d}, J=12.7 \mathrm{~Hz}, 1 \mathrm{H}), 1.77$ (s, 1H). $N$-Fmoc protection of 3-Cl-L-homotyrosine was performed without intermediate purification and as outlined previously. A colorless powder was isolated (106 mg, $0.23 \mathrm{mmol}, 60 \%$ yield). ${ }^{1} \mathrm{H} \mathrm{NMR}\left(500 \mathrm{MHz},\left(\mathrm{CD}_{3}\right)_{2} \mathrm{SO}\right) \delta 12.63(\mathrm{~s}, 1 \mathrm{H}), 10.02$ (s, 1H), $7.93-7.88(\mathrm{~m}, 2 \mathrm{H}), 7.75(\mathrm{dd}, J=7.7,2.4 \mathrm{~Hz}, 2 \mathrm{H}), 7.68(\mathrm{~d}, J=7.5 \mathrm{~Hz}, 1 \mathrm{H}), 7.43(\mathrm{t}, J=$ $7.5 \mathrm{~Hz}, 2 \mathrm{H}), 7.37-7.31(\mathrm{~m}, 2 \mathrm{H}), 7.31(\mathrm{~d}, J=2.1 \mathrm{~Hz}, 1 \mathrm{H}), 6.98(\mathrm{dd}, J=8.3,2.1 \mathrm{~Hz}, 1 \mathrm{H}), 6.86(\mathrm{~d}$, $J=8.2 \mathrm{~Hz}, 1 \mathrm{H}), 4.71(\mathrm{~d}, J=6.1 \mathrm{~Hz}, 1 \mathrm{H}), 4.36-4.22(\mathrm{~m}, 3 \mathrm{H}), 2.66-2.63(\mathrm{~m}, 1 \mathrm{H}), 2.39-2.35$ $(\mathrm{m}, 1 \mathrm{H})$.

Synthesis and purification of 7 mer substrates by Fmoc SPPS. The synthesis of $7 \mathrm{mer}$ hydrazine substrates followed the method described previously. ${ }^{1,2}$ Pure peptides were verified by HPLC-MS and average yields of synthesis were $80-85 \%$.

Synthesis and purification of coenzyme A adducts of 7 mer peptides. The preparation of coenzyme A adducts of 7mer hydrazine substrates followed the procedure outlined previously. ${ }^{1,2}$ The purified peptides were verified by HPLC-MS, aliquoted and lyophilized. Yields for generation of heptapeptides varied between $80-95 \%$.

Synthesis and purification of 7 mer peptides and coenzyme $A$ adducts of 43,46 and substrate for product 45 using Dawson resin SPPS. Synthesis of oxidation-prone peptides was 
adapted from previously described procedure. ${ }^{4}$ Dawson resin $(130 \mathrm{mg})$ was added to an EconoPac (Bio-Rad) column, swelled in DMF for 30 minutes and deprotected with a cocktail of $1 \%$ DBU in DMF ( $3 \times 2 \mathrm{~mL}$ ). Amino acids were coupled as previously described. ${ }^{1}$ Resin activation was carried out by adding a solution of $p$-nitrochloroformate ( $66 \mathrm{mg}, 5.0$ equivalents) in DCM (6.6 $\mathrm{mL}$ ), gently agitating with $\mathrm{N}_{2}$ bubbling at room temperature for 40 minutes and finally washing the resin with DCM $(3 \times 2 \mathrm{~mL})$ and DMF $(3 \times 2 \mathrm{~mL})$. Subsequently, a solution of DIPEA (58 uL, 5.0 equivalents) in DMF (3.9 mL) was added to the resin, which was allowed to agitate at room temperature for 15 minutes. After thorough washing with DMF $(3 \times 2 \mathrm{~mL})$ and DCM $(3 \times 2 \mathrm{~mL})$, the resin was dried under vacuum and transferred to a $25-\mathrm{mL}$ pear-shaped flask equipped with a stir bar, rubber septum and $\mathrm{N}_{2}$ inlet. DMF $(3.3 \mathrm{~mL})$ was added to the resin, which was allowed to swell with stirring for 20 minutes. For peptide cleavage, the resin suspension was degassed by bubbling $\mathrm{N}_{2}$ for 20 minutes and charged with a degassed solution of 4-mercaptophenylacetic acid (4-MPAA, $110 \mathrm{mg}, 10$ equivalents) in DMF $(0.65 \mathrm{~mL})$. Tributylphosphine (262 uL, $0.96 \mathrm{mmol}$, 24 equivalents) was added to the resin suspension via syringe and the cleavage reaction was allowed to proceed at room temperature for $24 \mathrm{~h}$, under inert gas. The resin residue was then filtered, and the filtrate was concentrated by rotatory evaporation. To remove side-chain protecting groups, a cocktail of TFA:TIS: $\mathrm{H}_{2} \mathrm{O}(95: 2.5: 2.5,6 \mathrm{~mL})$ was added to the 4-MPAA-peptide adduct, stirred for 90 minutes at room temperature and subsequently removed under a stream of $\mathrm{N}_{2}$. The resulting peptide was precipitated by adding cold $\mathrm{Et}_{2} \mathrm{O}$, which was then decanted. The crude 4-MPAA-peptide adduct was verified by HPLC-MS. A portion of the crude material (2.65 $\mathrm{mg}$, corresponding to approximately $2.25 \mu \mathrm{mol}$ of peptide, as quantified by UV-Vis spectroscopy), was dissolved in $50 \mathrm{mM}$ phosphate buffer $\mathrm{pH} 8.3(0.9 \mathrm{~mL})$ and $\mathrm{MeCN}(0.45 \mathrm{~mL})$. A final concentration of $20 \mathrm{mM}$ TCEP was added to the thioester exchange reaction from a $500 \mathrm{mM}$ stock solution at $\mathrm{pH}$ 7.0. Finally, the exchange reaction was charged with coenzyme A ( $7 \mathrm{mg}, 9$ umol, 4.0 equivalents) and adjusted to $\mathrm{pH} 8.3$. The reaction was allowed to stir at room temperature for 2 hours and the peptide-coenzyme A adducts were purified via repeated injections onto an analytical Phenomenex Luna C18 column $(5 \mu \mathrm{m}, 250 \times 4.6 \mathrm{~mm})$ that had been equilibrated with $10 \% \mathrm{MeCN}$ in $\mathrm{H}_{2} \mathrm{O}(+0.1 \%$ FA). The peptide-CoA adducts were eluted with a gradient of $10-$ $55 \% \mathrm{MeCN}$ in $\mathrm{H}_{2} \mathrm{O}(+0.1 \% \mathrm{FA})$ over 17 minutes. The purified material was verified by HPLCMS, aliquoted, and lyophilized. Yields for this synthetic procedure were on average $2 \%$. 
Enzymatic reactions with OxyB. A typical analytical-scale reaction with OxyB was carried out on a $100 \mu \mathrm{L}$ scale. Loading buffer (50 mM HEPES, $20 \mathrm{mM} \mathrm{KCl}, 10 \mathrm{mM} \mathrm{MgCl}$, $\mathrm{pH}$ 7.0) was added to an Eppendorf tube containing $20 \mathrm{nmol}$ of lyophilized peptide-CoA adduct, to a final peptide concentration of $400 \mu \mathrm{M}$. Subsequently, final concentrations of $400 \mu \mathrm{M} \mathrm{PCP}-\mathrm{X}$ and $80 \mu \mathrm{M}$ of Sfp R4-4 were added to the reaction mixture, which was placed in a $30^{\circ} \mathrm{C}$ incubator for one hour. In standard reactions, final concentrations of the following reagents were added to the reaction mixture, in this order: $4 \mathrm{mM}$ glucose-6-phosphate, $0.04 \mathrm{U} / \mu \mathrm{L}$ glucose-6-phosphate dehydrogenase, $20 \mu \mathrm{M}$ spinach ferredoxin, $8 \mu \mathrm{M} \mathrm{E}$. coli ferredoxin reductase, $20 \mu \mathrm{M}$ OxyB. The oxidative crosslinking reaction was initiated by the addition of $2 \mathrm{mM} \mathrm{NADPH}$. We tested several re-reducing systems with substrates $\mathbf{6}, \mathbf{1 5}, \mathbf{2 5}$, and $\mathbf{3 2}$, and found that the spinach ferredoxin/E. coli ferredoxin reductase yielded the highest conversion rates; this pair was previously also shown to be most effective in $\mathrm{OxyB}_{\mathrm{van}}$ crosslinking reactions. ${ }^{5,6}$ Alternative reduction systems, such as the ferredoxin/ferredoxin reductase pair from Rhodopseudomonas palustris, led to identical product outcomes, though at lower rates, when compared to spinach ferredoxin/E. coli ferredoxin reductase. ${ }^{3}$ Typical assays were carried out at room temperature for 3 hours in the dark, at which point the reactions were complete; we previously showed that product formation plateaus by 50 min even with poor substrates. ${ }^{1}$ In order to remove the peptide from the carrier domain, 20,000 equivalents of propylamine were added and the reaction mixture incubated for 15 minutes. Proteins were precipitated by adding $15 \mu \mathrm{L}$ of formic acid and $50 \mu \mathrm{L}$ of $\mathrm{MeCN}(+0.1 \%$ FA). Denatured proteins were pelleted, and the supernatant was analyzed by HR-HPLC-MS and HR-MS/MS.

\section{Enzymatic reaction of $4(\mathrm{AA2}=\mathrm{L}-\mathrm{Hpg}$; AA4 $=\mathrm{D}-\mathrm{Hpg})$ with OxyB and purification}

of product 5. This reaction was carried out on a $10.6 \mathrm{~mL}$ scale. Loading buffer (50 mM HEPES, $20 \mathrm{mM} \mathrm{KCl}, 10 \mathrm{mM} \mathrm{MgCl}$, $\mathrm{pH} 7.0$ ) was added to $2.14 \mu \mathrm{mol}$ of lyophilized 7mer-CoA adduct, to a final peptide concentration of $400 \mu \mathrm{M}$. PCP-X and Sfp R4-4 were added to final concentrations of $400 \mu \mathrm{M}$ and $80 \mu \mathrm{M}$, respectively, and loading reaction was placed in an incubator at $30^{\circ} \mathrm{C}$. Final concentrations of the following components were then added to the reaction, in this order: 4mM G6P, $0.04 \mathrm{U} / \mu \mathrm{L}$ G6P-DH, $20 \mu \mathrm{M}$ spinach ferredoxin, $8 \mu \mathrm{M}$ ferredoxin reductase, $7.5 \mu \mathrm{M}$ OxyB and $4 \mathrm{mM}$ NADPH. The reaction proceeded for $3 \mathrm{~h}$, at room temperature, shielded from light. The peptide was cleaved from PCP-X through the addition of 20,000 equivalents of propyl amine and the reaction was incubated for $15 \mathrm{~min}$. Proteins were then precipitated by adding formic 
acid $(15 \% \mathrm{v} / \mathrm{v})$ and $\mathrm{MeCN}(50 \% \mathrm{v} / \mathrm{v})$. Purification of the resulting product was carried out through repeated injections onto a Phenomenex Luna C18 column $(5 \mu \mathrm{m}, 250 \mathrm{~mm} \times 10 \mathrm{~mm})$, initially equilibrated with 5\% MeCN. $5(0.4 \mathrm{mg})$ was eluted with a gradient of 5-44\% over $20 \mathrm{~min}$ and dried in vacuo.

\section{Enzymatic reaction of $6(\mathrm{AA2}=\mathrm{L}-\mathrm{Tyr}$; AA4 $=$ D-Tyr $)$ with OxyB and purification of} product 7. This reaction was carried out on a $5.0 \mathrm{~mL}$ scale. Loading buffer (50 mM HEPES, 20 $\mathrm{mM} \mathrm{KCl}, 10 \mathrm{mM} \mathrm{MgCl}$, $\mathrm{pH}$ 7.0) was added to $1.00 \mu \mathrm{mol}$ of lyophilized 7mer-CoA adduct, to a final peptide concentration of $400 \mu \mathrm{M}$. PCP-X and Sfp R4-4 were added to final concentrations of $400 \mu \mathrm{M}$ and $80 \mu \mathrm{M}$, respectively, and loading reaction was placed in an incubator at $30^{\circ} \mathrm{C}$. Final concentrations of the following components were then added to the reaction, in this order: $4 \mathrm{mM}$ G6P, $0.04 \mathrm{U} / \mu \mathrm{L}$ G6P-DH, $20 \mu \mathrm{M}$ spinach ferredoxin, $8 \mu \mathrm{M}$ ferredoxin reductase, $20 \mu \mathrm{M}$ OxyB and $4 \mathrm{mM} \mathrm{NADPH}$. The reaction proceeded for $3 \mathrm{~h}$, at room temperature, shielded from light. The peptide was cleaved from PCP-X through the addition of 20,000 equivalents of propyl amine and the reaction was incubated for $15 \mathrm{~min}$. Proteins were then precipitated by adding formic acid (15\% $\mathrm{v} / \mathrm{v})$ and $\mathrm{MeCN}(50 \% \mathrm{v} / \mathrm{v})$. Purification of the resulting product was carried out through repeated injections onto a Supelco Discovery RP Amide C16 column $(5 \mu \mathrm{m}, 250 \mathrm{~mm}$ x $10 \mathrm{~mm})$, initially equilibrated with $10 \% \mathrm{MeCN} .7(0.3 \mathrm{mg})$ was eluted with a gradient of $10-44 \%$ over $30 \mathrm{~min}$ and dried in vacuo.

\section{Enzymatic reaction of $15(\mathrm{AA2}=\mathrm{L}-\mathrm{Tyr}$; AA4 $=\mathrm{L}-\mathrm{Hpg})$ with OxyB and purification}

of product 16. This reaction was carried out on a $26.3 \mathrm{~mL}$ scale. Loading buffer (50 mM HEPES, $20 \mathrm{mM} \mathrm{KCl}, 10 \mathrm{mM} \mathrm{MgCl}$, $\mathrm{pH}$ 7.0) was added to $5.26 \mu \mathrm{mol}$ of lyophilized 7mer-CoA adduct, to a final peptide concentration of $400 \mu \mathrm{M}$. PCP-X and Sfp R4-4 were added to final concentrations of $400 \mu \mathrm{M}$ and $80 \mu \mathrm{M}$, respectively, and loading reaction was placed in an incubator at $30^{\circ} \mathrm{C}$. Final concentrations of the following components were then added to the reaction, in this order: 4mM G6P, $0.04 \mathrm{U} / \mu \mathrm{L}$ G6P-DH, $20 \mu \mathrm{M}$ spinach ferredoxin, $8 \mu \mathrm{M}$ ferredoxin reductase, $8 \mu \mathrm{M}$ OxyB and $4 \mathrm{mM}$ NADPH. The reaction proceeded for $3 \mathrm{~h}$, at room temperature, shielded from light. The peptide was cleaved from PCP-X through the addition of 20,000 equivalents of propyl amine and the reaction was incubated for $15 \mathrm{~min}$. Proteins were then precipitated by adding formic $\operatorname{acid}(15 \% \mathrm{v} / \mathrm{v})$ and $\mathrm{MeCN}(50 \% \mathrm{v} / \mathrm{v})$. Purification of the resulting product was carried out through 
repeated injections onto a Phenomenex Luna C18 column $(5 \mu \mathrm{m}, 250 \mathrm{~mm} \times 10 \mathrm{~mm})$, initially equilibrated with $5 \% \mathrm{MeCN} .16(0.3 \mathrm{mg})$ was eluted with a gradient of $5-44 \%$ over $20 \mathrm{~min}$ and dried in vacuo.

\section{Enzymatic reaction of $25(\mathrm{AA2}=\mathrm{L}-\mathrm{Tyr}$; AA4 $=\mathrm{D}-\mathrm{PhGly})$ with $\mathrm{OxyB}$ and purification}

of product 26. This reaction was carried out on a $14.5 \mathrm{~mL}$ scale. Loading buffer (50 mM HEPES, $20 \mathrm{mM} \mathrm{KCl}, 10 \mathrm{mM} \mathrm{MgCl}$, $\mathrm{pH} \mathrm{7.0)}$ was added to $2.9 \mu \mathrm{mol}$ of lyophilized 7mer-CoA adduct, to a final peptide concentration of $400 \mu \mathrm{M}$. PCP-X and Sfp R4-4 were added to final concentrations of $400 \mu \mathrm{M}$ and $80 \mu \mathrm{M}$, respectively, and loading reaction was placed in an incubator at $30^{\circ} \mathrm{C}$. Final concentrations of the following components were then added to the reaction, in this order: 4mM G6P, $0.04 \mathrm{U} / \mu \mathrm{L}$ G6P-DH, $20 \mu \mathrm{M}$ spinach ferredoxin, $8 \mu \mathrm{M}$ ferredoxin reductase, $30 \mu \mathrm{M}$ OxyB and $4 \mathrm{mM}$ NADPH. The reaction proceeded for $3 \mathrm{~h}$, at room temperature, shielded from light. The peptide was cleaved from PCP-X through the addition of 20,000 equivalents of propyl amine and the reaction was incubated for $15 \mathrm{~min}$. Proteins were then precipitated by adding formic $\operatorname{acid}(15 \% \mathrm{v} / \mathrm{v})$ and $\mathrm{MeCN}(50 \% \mathrm{v} / \mathrm{v})$. Purification of the resulting product was carried out through repeated injections onto a Phenomenex Luna C18 column $(5 \mu \mathrm{m}, 250 \mathrm{~mm} \times 10 \mathrm{~mm})$, initially equilibrated with $5 \% \mathrm{MeCN}$. 26 (0.9 mg) was eluted with a gradient of 5-49\% over $20 \mathrm{~min}$ and dried in vacuo.

Large-scale enzymatic reaction of 32 (AA2 $=$ L-Phe; AA4 $=$ D-PhGly) with OxyB and purification of product 33. This reaction was carried out on a $24 \mathrm{~mL}$ scale. Loading buffer (50 mM HEPES, $20 \mathrm{mM} \mathrm{KCl}, 10 \mathrm{mM} \mathrm{MgCl}$, $\mathrm{pH} \mathrm{7.0)} \mathrm{was} \mathrm{added} \mathrm{to} 4.8 \mu \mathrm{mol}$ of lyophilized 7merCoA adduct, to a final peptide concentration of $400 \mu \mathrm{M}$. PCP-X and Sfp R4-4 were added to final concentrations of $200 \mu \mathrm{M}$ and $80 \mu \mathrm{M}$, respectively, and loading reaction was placed in an incubator at $30{ }^{\circ} \mathrm{C}$. Final concentrations of the following components were then added to the reaction, in this order: 4mM G6P, $0.04 \mathrm{U} / \mu \mathrm{L}$ G6P-DH, $20 \mu \mathrm{M}$ spinach ferredoxin, $8 \mu \mathrm{M}$ ferredoxin reductase, $60 \mu \mathrm{M}$ OxyB and $4 \mathrm{mM}$ NADPH. The reaction proceeded for $3 \mathrm{~h}$, at room temperature, shielded from light. The peptide was cleaved from PCP-X through the addition of 20,000 equivalents of propyl amine and the reaction was incubated for $15 \mathrm{~min}$. Proteins were then precipitated by adding formic acid $(15 \% \mathrm{v} / \mathrm{v})$ and $\mathrm{MeCN}(50 \% \mathrm{v} / \mathrm{v})$. Purification of the resulting 
product was carried out through repeated injections onto a Phenomenex Luna C18 column $(5 \mu \mathrm{m}$, $250 \mathrm{~mm} \times 10 \mathrm{~mm})$, initially equilibrated with $10 \% \mathrm{MeCN} .33(0.3 \mathrm{mg})$ was eluted with a gradient of $10-55 \%$ over $20 \mathrm{~min}$ and dried in vacuo.

Fluorescence Assays for products 44, 47. A typical enzymatic reaction with OxyB was carried out as previously described above. Purification of OxyB product was achieved by repeated injections onto an analytical Phenomenex Luna C18 column $(5 \mu \mathrm{m}, 250 \times 4.6 \mathrm{~mm})$ that had been equilibrated with $10 \% \mathrm{MeCN}$ in $\mathrm{H}_{2} \mathrm{O}(+0.1 \% \mathrm{FA})$. The OxyB product was eluted with a gradient of $10-55 \% \mathrm{MeCN}$ in $\mathrm{H}_{2} \mathrm{O}(+0.1 \%$ FA) over 20 minutes. The purified material was verified by HPLC-MS, aliquoted and lyophilized. After lyophilization, 20 to $50 \mu \mathrm{L}$ of DMSO was added to the purified OxyB product and subsequently transferred to a 96-well plate in the Synergy H1 Microplate Reader. Fluorescence experiments were performed at $\lambda_{\text {excite }}=288 \mathrm{~nm}$ and $\lambda_{\text {excite }}=310$ $\mathrm{nm}$, which correspond to the $\lambda_{\max }$ of diphenylamine and 2-aminobiphenyl, respectively.

Antibiotic Activity Assays. E. coli K12 (wt, Kolter lab collection), Enterococcus faecalis OG1RF (ATCC), Staphylococcus aureus Newman (wt, Muir lab collection), Vibrio cholerae (wt, Bassler lab collection), and Saccharomyces cerevisiae ZSR3385 (wt, Kolter lab collection) were used for antibiotic assays. E. coli and E. faecalis were cultured in LB broth at $37^{\circ} \mathrm{C}$. S. aureus was cultured in Brain-Heart Infusion (BHI) medium at $37^{\circ} \mathrm{C}$, and $V$. cholera was grown in marine broth at $37^{\circ} \mathrm{C}$. S. cerevisiae was cultured at $30^{\circ} \mathrm{C}$ in YPM medium $(0.5 \%$ yeast extract, $0.3 \%$ peptone, $2.5 \%$ mannitol). Bioactivity assays were carried out in accordance to the 2003 guidelines of the Clinical and Laboratory Standards Institute (CLSI) using the microtiter method. Microbial seed cultures were initiated by inoculating $5 \mathrm{~mL}$ of the specified medium for each strain and by incubating overnight at the indicated temperatures and shaking at $200 \mathrm{rpm}$. Each culture was then diluted with Mueller-Hinton broth to an initial OD600 nm of 0.02 in $80 \mu \mathrm{L}$ volume per well in a 96-well plate. The wells contained varying concentrations of the compounds tested: 0, 0.02, 0.04, $0.1,0.2,0.4,1,3,8,20,40 \mu \mathrm{M}$ final concentration, in DMSO. Assays were set-up in duplicates, with appropriate controls. The plates were then incubated at the temperatures listed above without shaking and OD600 nm was determined after 2 h, 4 h, $6 \mathrm{~h}$ and 8 h. Both replicates gave nearidentical $\mathrm{IC}_{50} \mathrm{~s}$. The reported error is based on systematic error from determination of the concentration of the monocyclic peptides, which we estimate at $15 \%$. 
Enzymatic reactions with OxyB, OxyA, OxyC. Analytical-scale reactions with OxyB, OxyA and OxyC were carried out as previously described. ${ }^{2}$ 

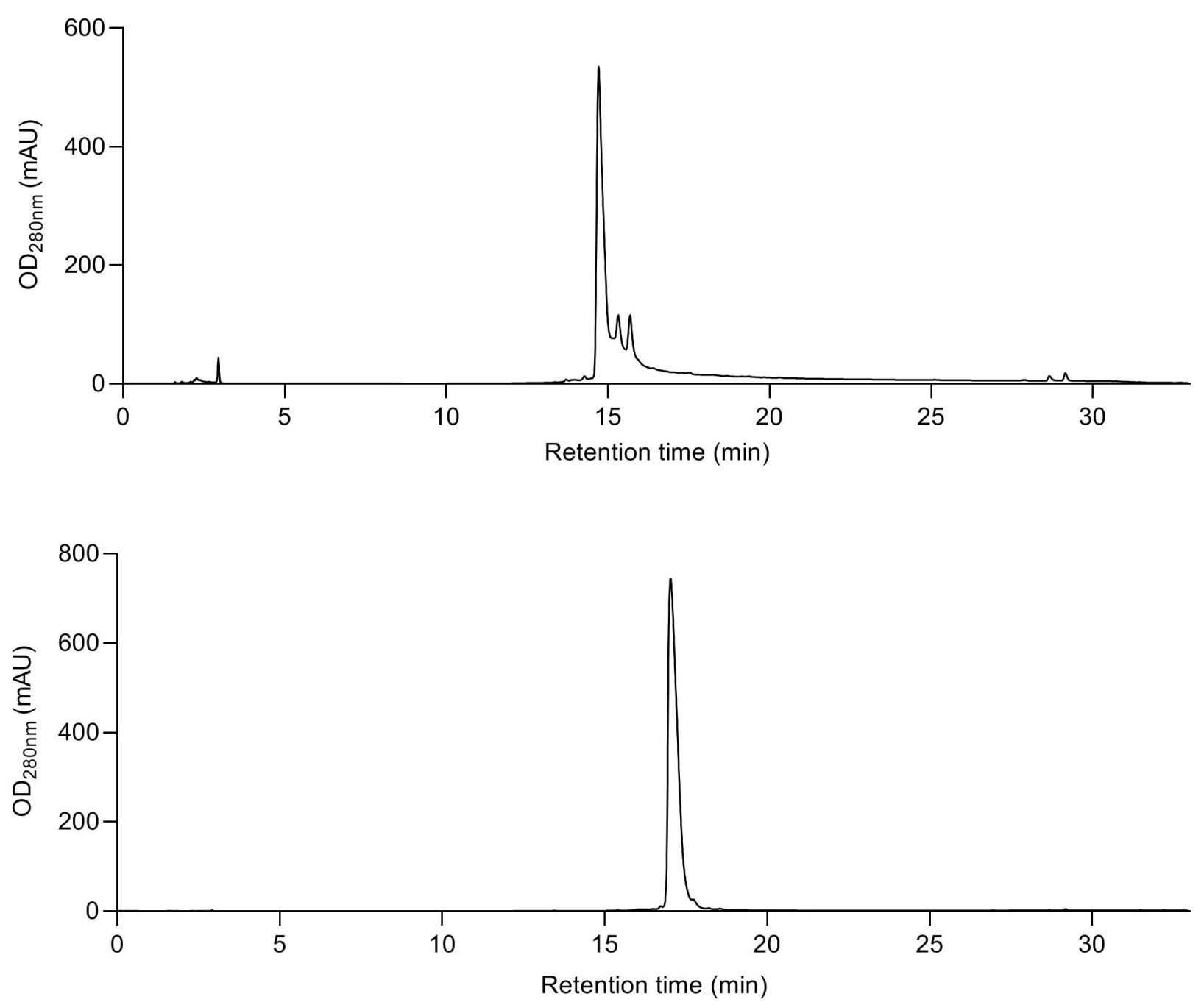

Figure S1. HPLC-MS analysis of pure $\mathbf{4}$ as a 7 mer hydrazide (top) and as a CoA thioester adduct (bottom). 

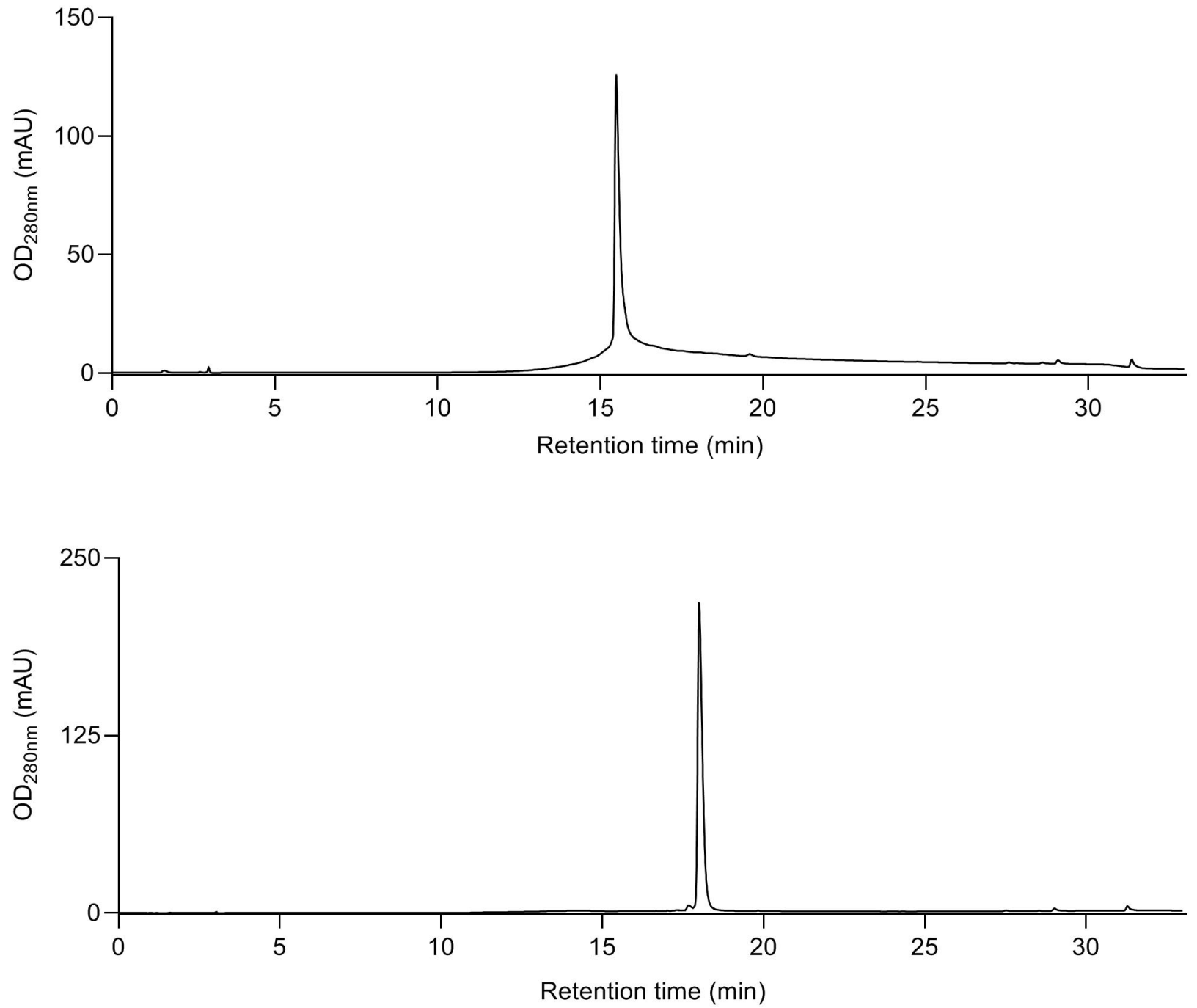

Figure S2. HPLC-MS analysis of pure $\mathbf{6}$ as a 7 mer hydrazide (top) and as a CoA thioester adduct (bottom). 

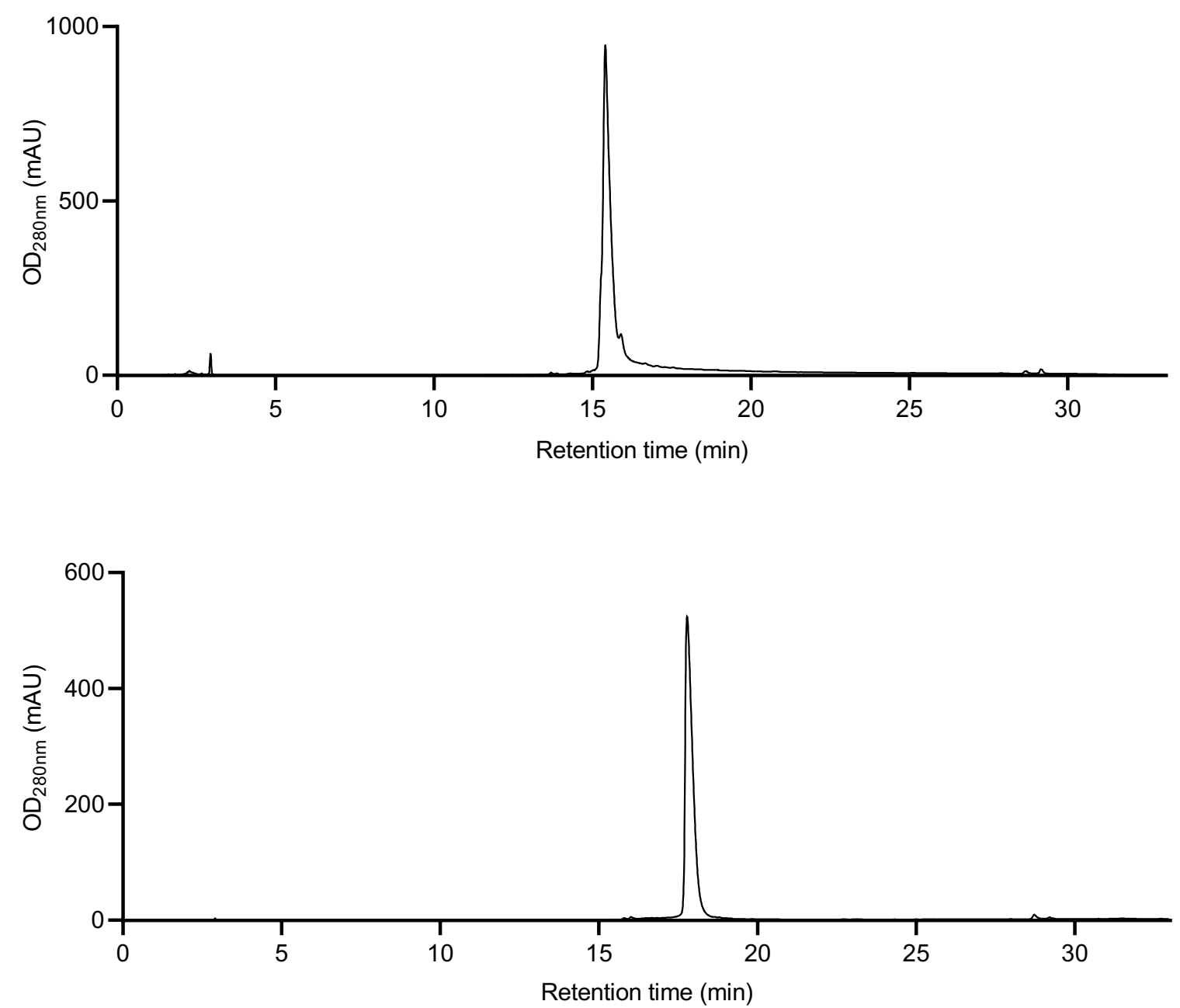

Figure S3. HPLC-MS analysis of pure 8 as a 7 mer hydrazide (top) and as a CoA thioester adduct (bottom). 

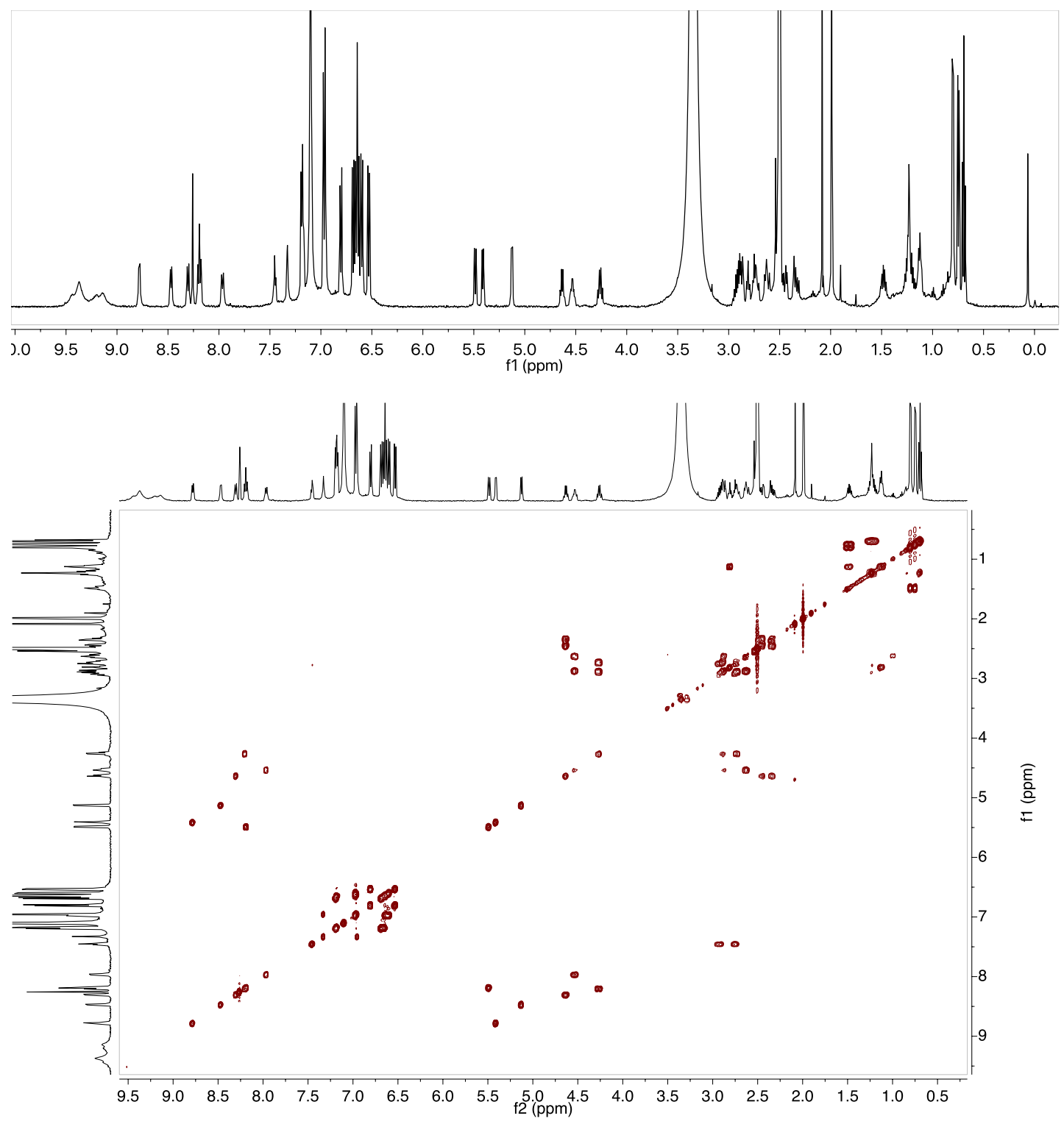

Figure S4. $800 \mathrm{MHz}{ }^{1} \mathrm{H}$ NMR of 4 in $\left(\mathrm{CD}_{3}\right)_{2} \mathrm{SO}$ (top). $800 \mathrm{MHz} \mathrm{COSY}$ spectra of 4 in $\left(\mathrm{CD}_{3}\right)_{2} \mathrm{SO}$ (bottom). 

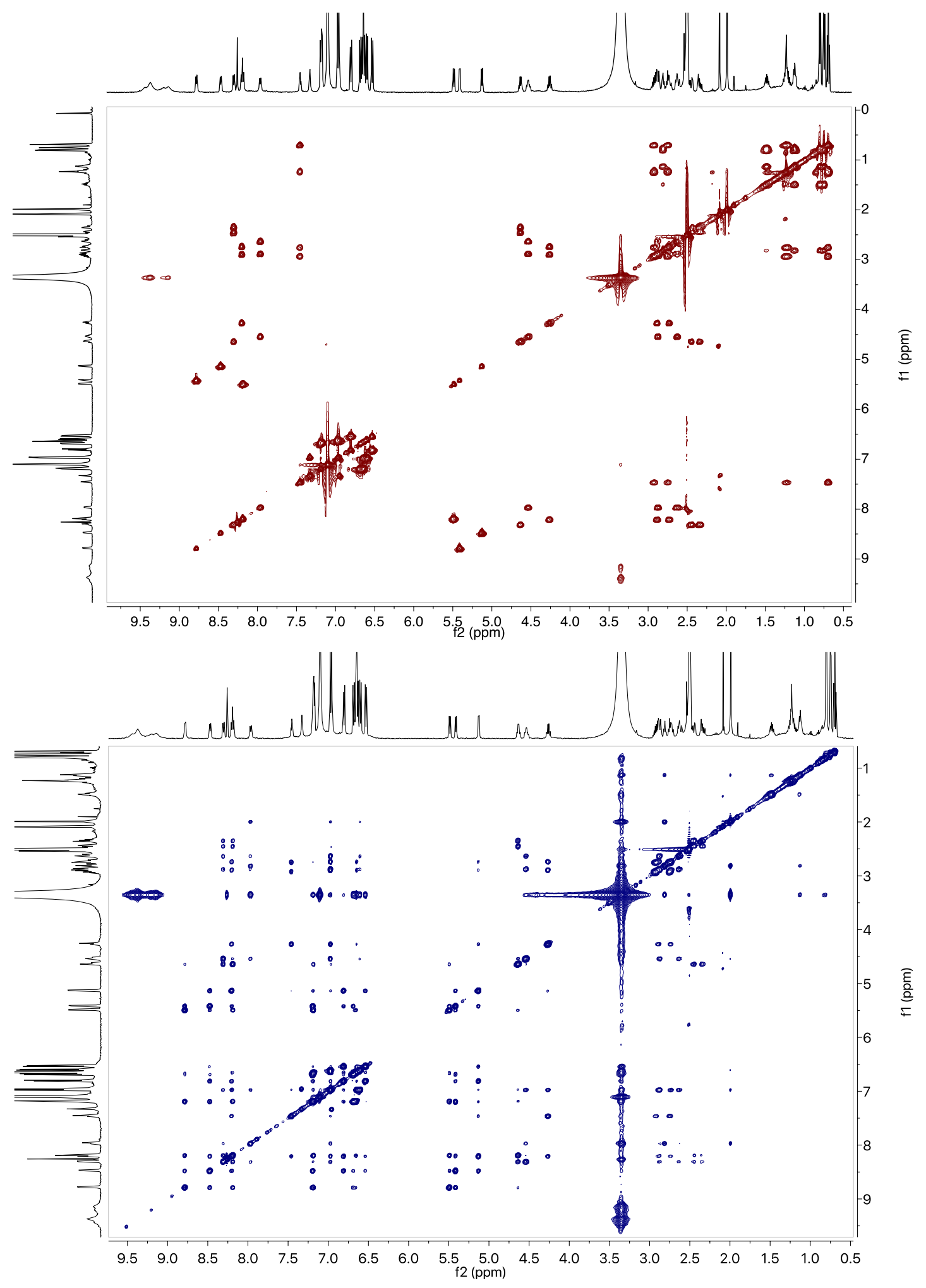

Figure S5. $800 \mathrm{MHz}$ TOCSY spectra of 4 in $\left(\mathrm{CD}_{3}\right)_{2} \mathrm{SO}$ (top). $800 \mathrm{MHz}$ NOESY spectra of 4 in $\left(\mathrm{CD}_{3}\right)_{2} \mathrm{SO}$ (bottom). 


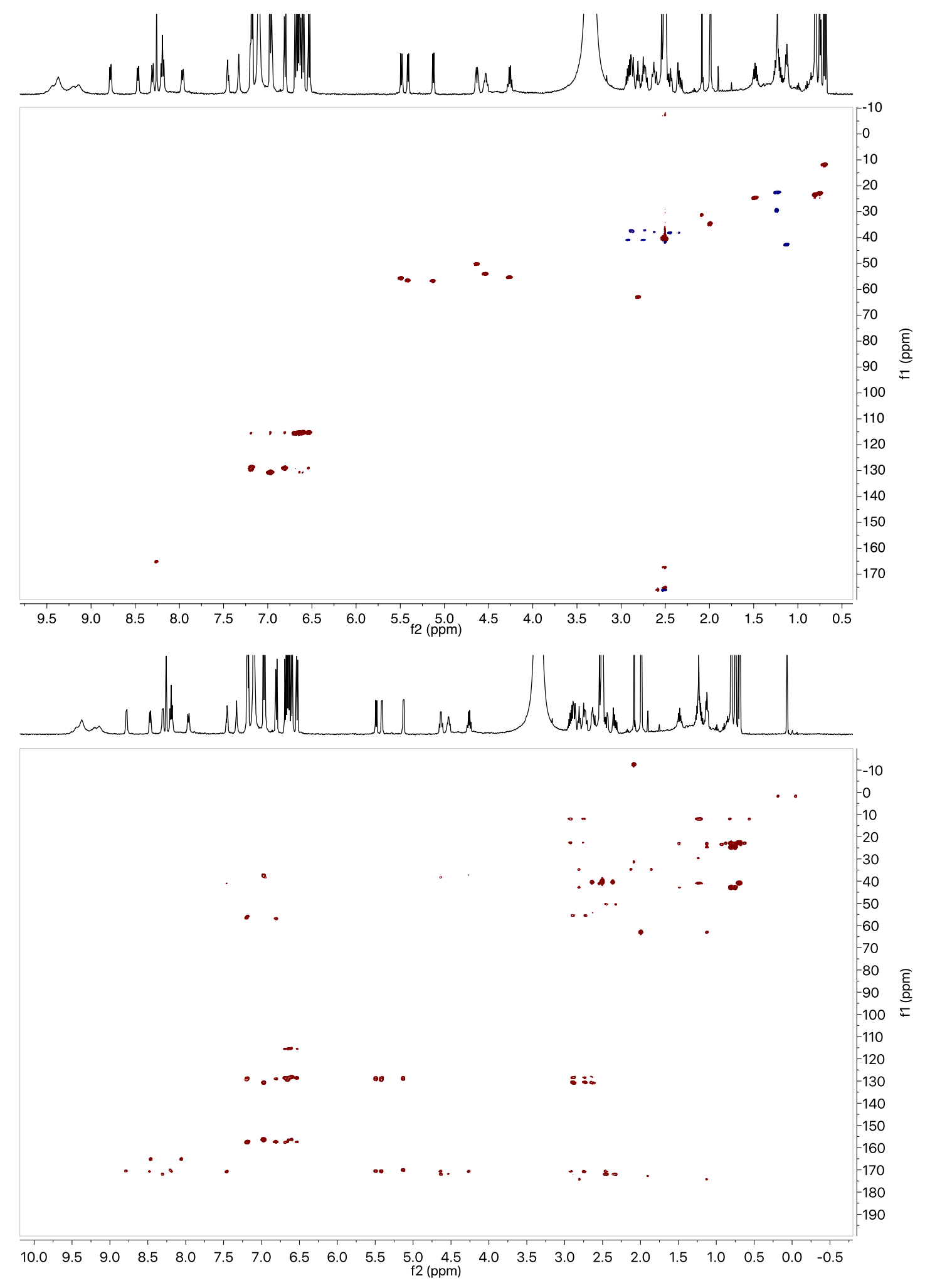

Figure S6. $800 \mathrm{MHz}$ HSQC spectra of 4 in $\left(\mathrm{CD}_{3}\right)_{2} \mathrm{SO}$ (top). $800 \mathrm{MHz} \mathrm{HMBC}$ spectra of 4 in $\left(\mathrm{CD}_{3}\right)_{2} \mathrm{SO}$ (bottom). 

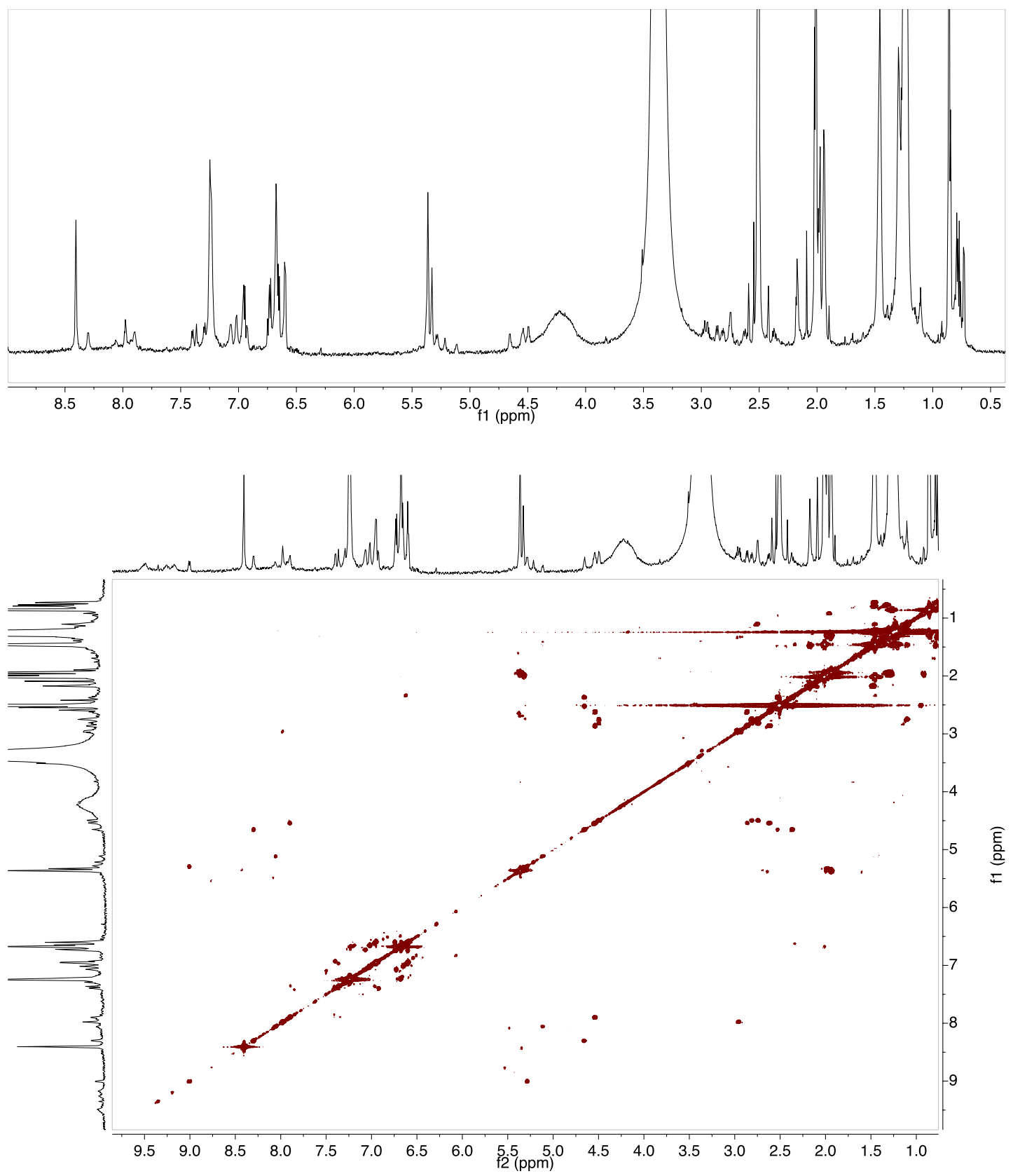

Figure $\mathbf{S 7} .800 \mathrm{MHz}{ }^{1} \mathrm{H}$ NMR of 5 in $\left(\mathrm{CD}_{3}\right)_{2} \mathrm{SO}$ (top). $800 \mathrm{MHz} \mathrm{COSY}$ spectra of $\mathbf{5}$ in $\left(\mathrm{CD}_{3}\right)_{2} \mathrm{SO}$ (bottom). 


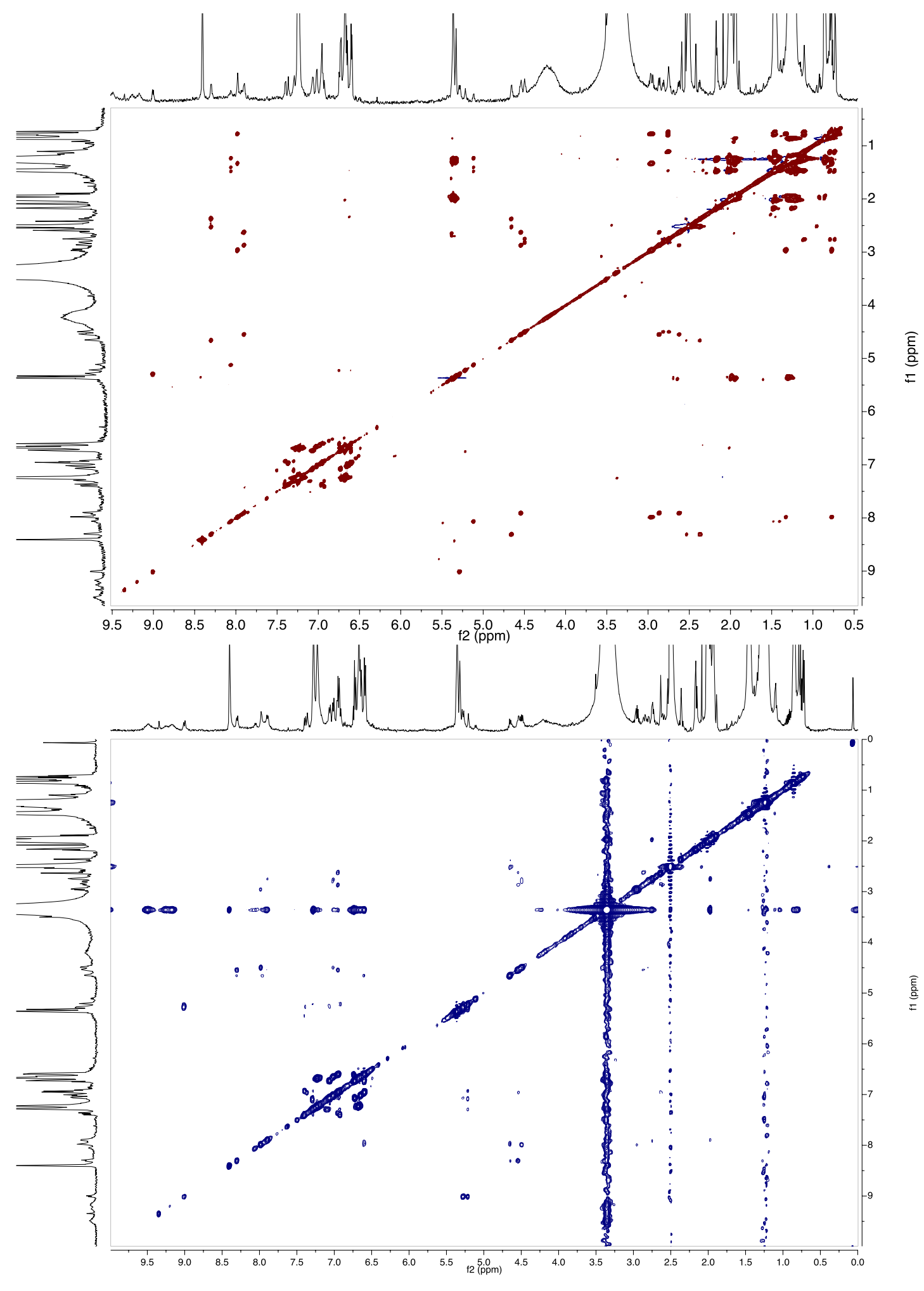

Figure S8. $800 \mathrm{MHz}$ TOCSY spectra of 5 in $\left(\mathrm{CD}_{3}\right)_{2} \mathrm{SO}$ (top). $800 \mathrm{MHz}$ NOESY spectra of 5 in $\left(\mathrm{CD}_{3}\right)_{2} \mathrm{SO}$ (bottom). 


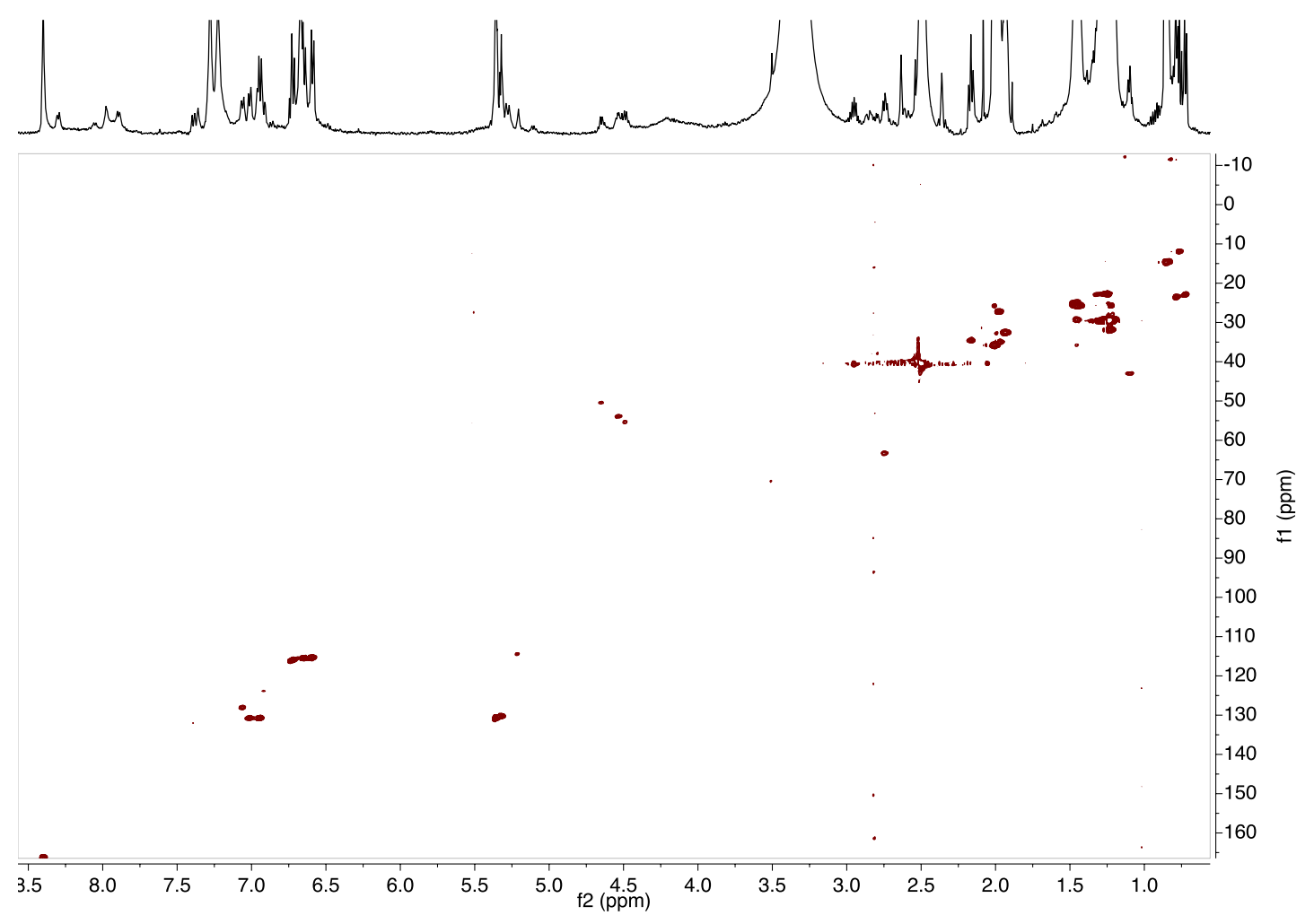

Figure S9. $800 \mathrm{MHz} H S Q C$ spectra of 5 in $\left(\mathrm{CD}_{3}\right)_{2} \mathrm{SO}$ (top). 

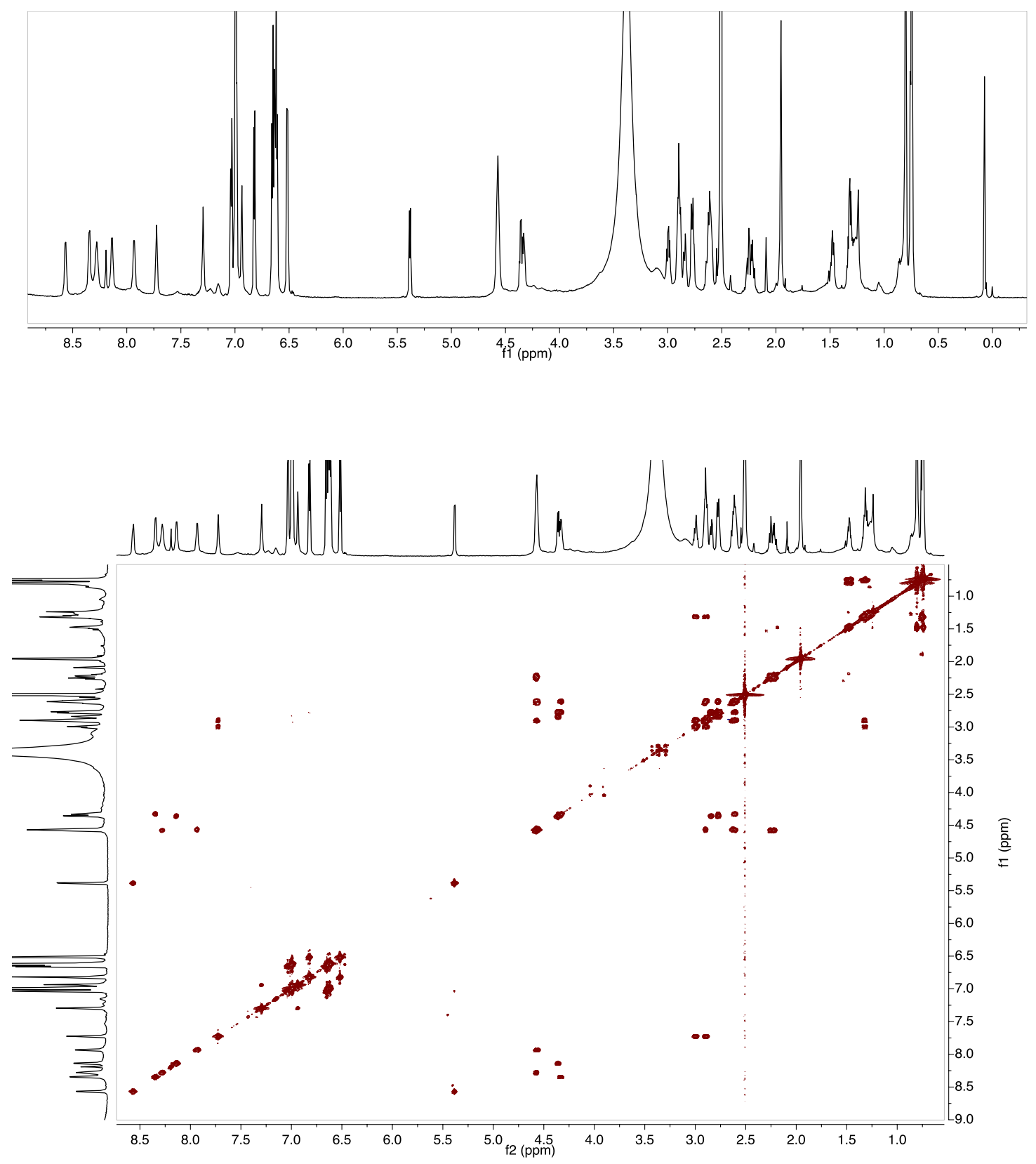

Figure S10. $800 \mathrm{MHz}{ }^{1} \mathrm{H}$ NMR of 6 in $\left(\mathrm{CD}_{3}\right)_{2} \mathrm{SO}$ (top). $800 \mathrm{MHz} \mathrm{COSY}$ spectra of 6 in $\left(\mathrm{CD}_{3}\right)_{2} \mathrm{SO}$ (bottom). 

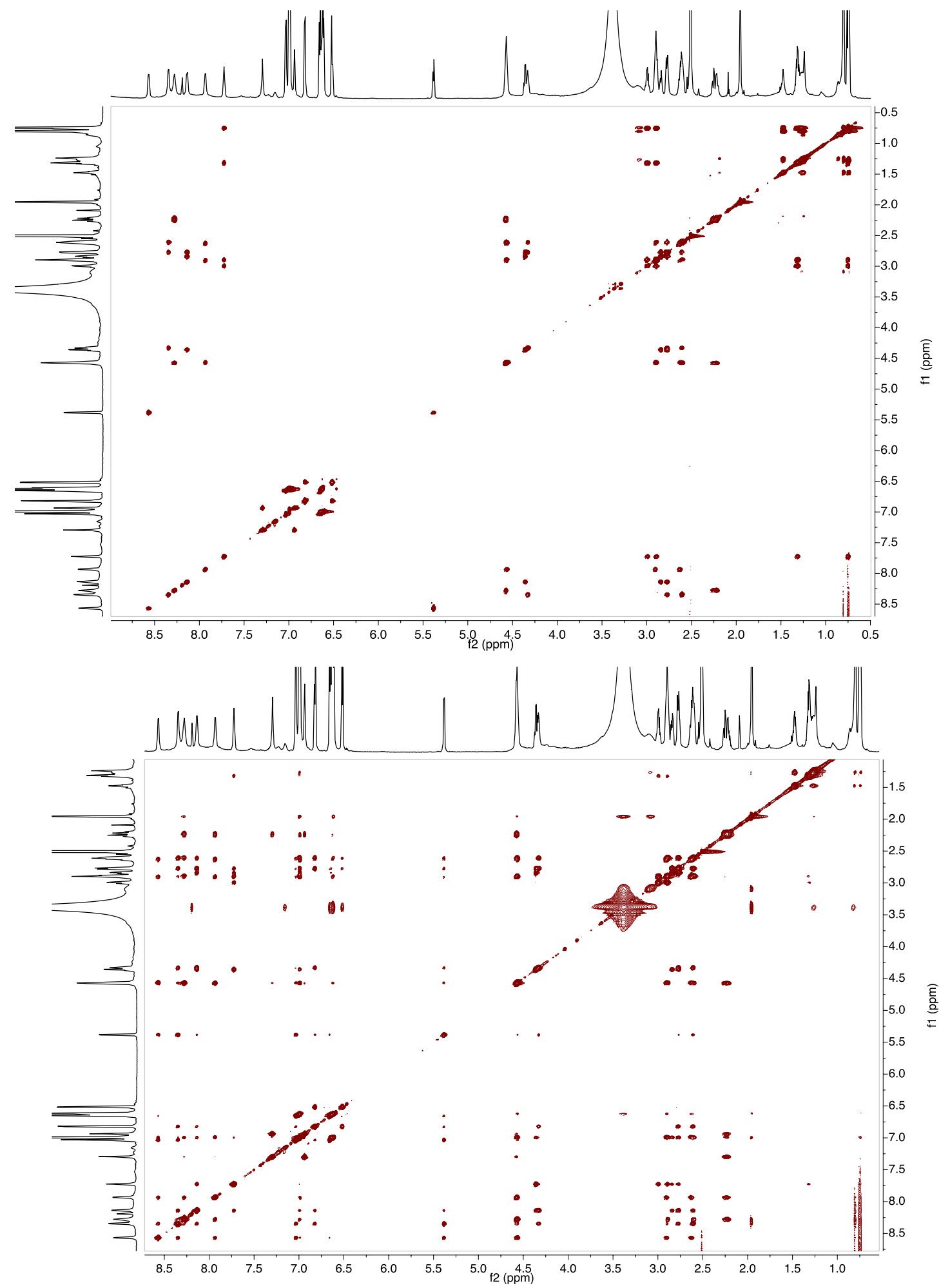

Figure S11. $800 \mathrm{MHz}$ TOCSY spectra of 6 in $\left(\mathrm{CD}_{3}\right)_{2} \mathrm{SO}$ (top). $800 \mathrm{MHz}$ NOESY spectra of 6 in $\left(\mathrm{CD}_{3}\right)_{2} \mathrm{SO}$ (bottom). 

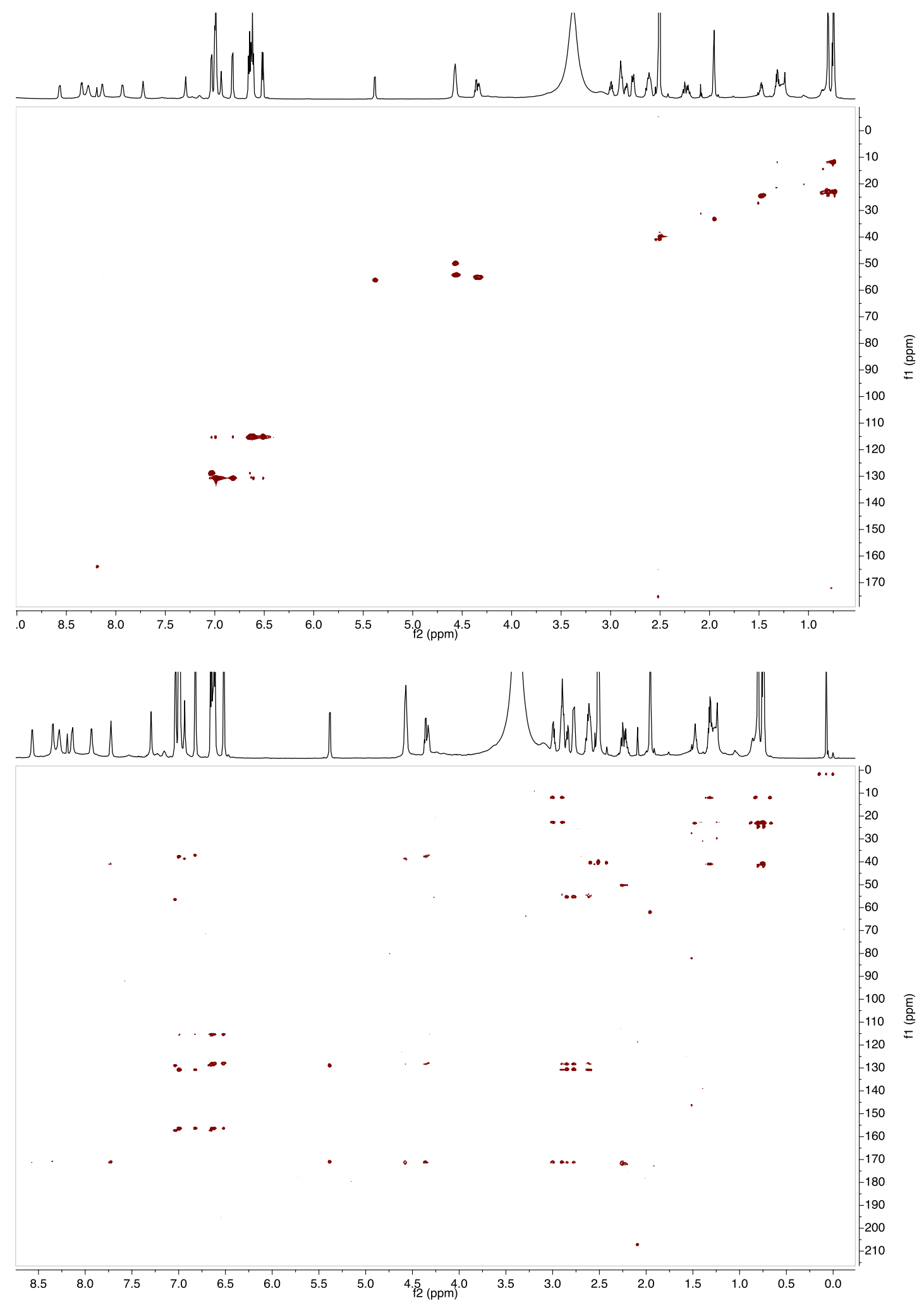

Figure S12. $800 \mathrm{MHz}$ HSQC spectra of 6 in $\left(\mathrm{CD}_{3}\right)_{2} \mathrm{SO}$ (top). $800 \mathrm{MHz} \mathrm{HMBC}$ spectra of $\mathbf{6}$ in $\left(\mathrm{CD}_{3}\right)_{2} \mathrm{SO}$ (bottom). 

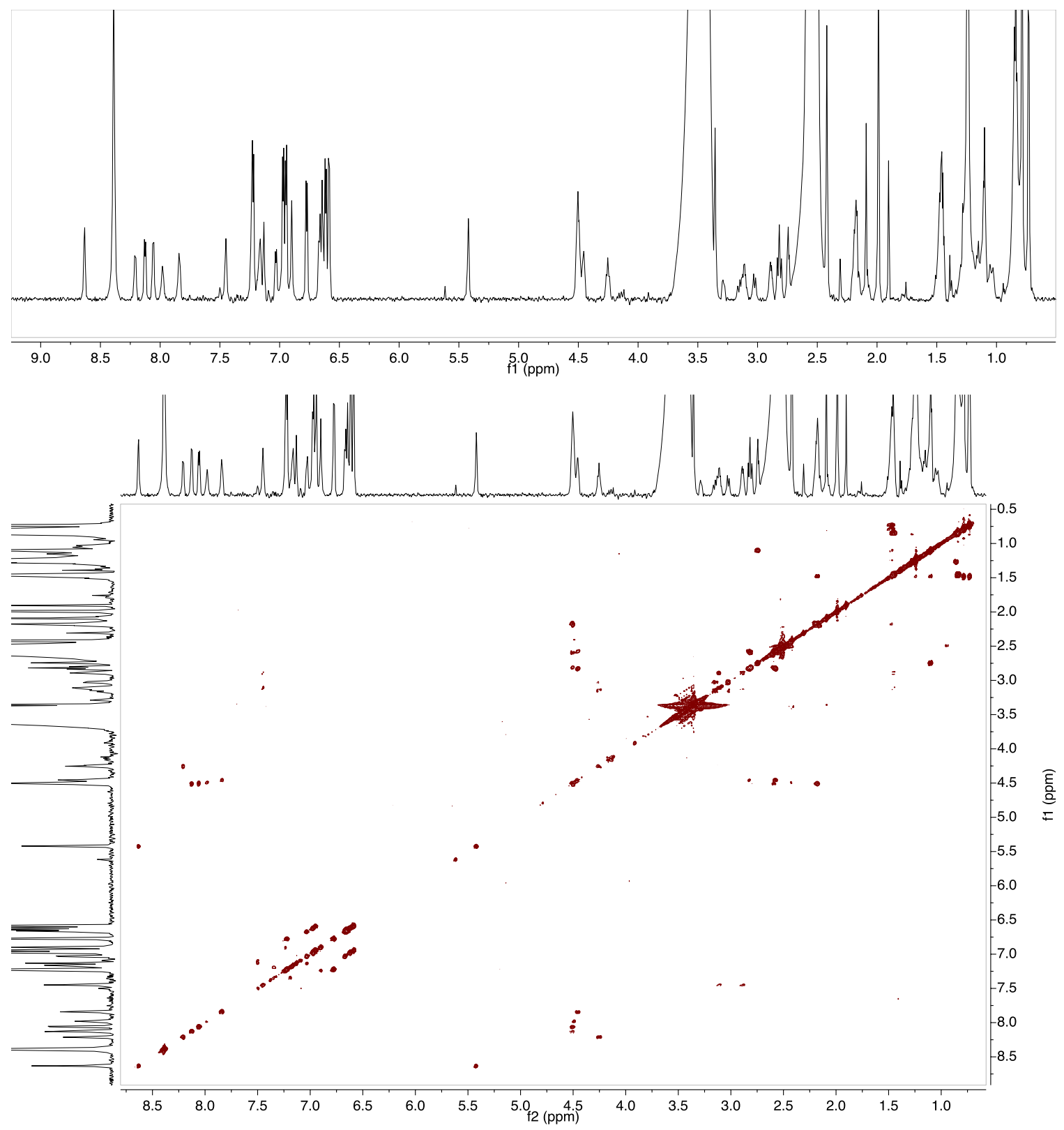

Figure S13. $800 \mathrm{MHz}{ }^{1} \mathrm{H}$ NMR of 7 in $\left(\mathrm{CD}_{3}\right)_{2} \mathrm{SO}$ (top). $800 \mathrm{MHz} \mathrm{COSY}$ spectra of 7 in $\left(\mathrm{CD}_{3}\right)_{2} \mathrm{SO}$ (bottom). 

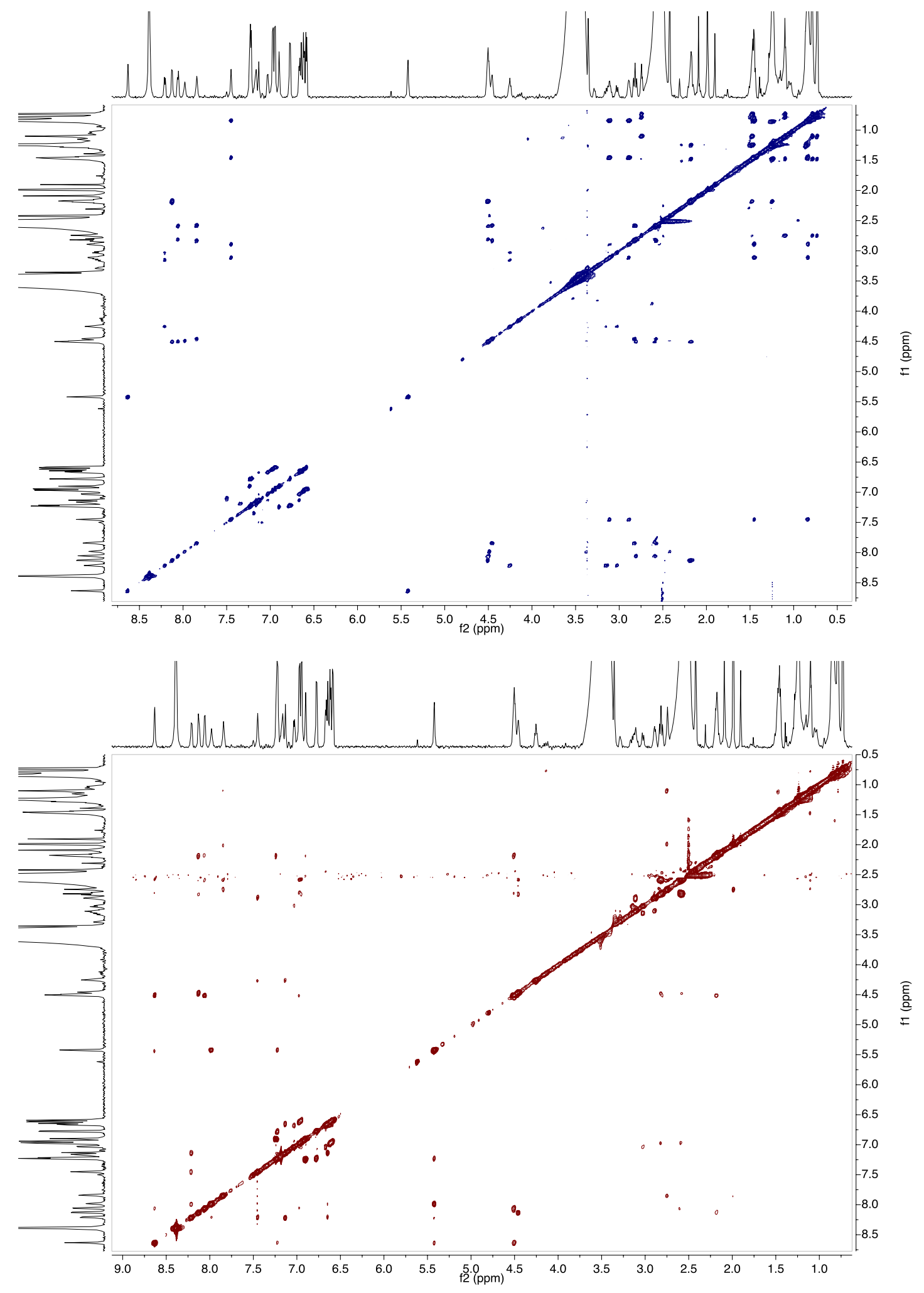

Figure S14. $800 \mathrm{MHz}$ TOCSY spectra of 7 in $\left(\mathrm{CD}_{3}\right)_{2} \mathrm{SO}$ (top). $800 \mathrm{MHz}$ NOESY spectra of 7 in $\left(\mathrm{CD}_{3}\right)_{2} \mathrm{SO}$ (bottom). 


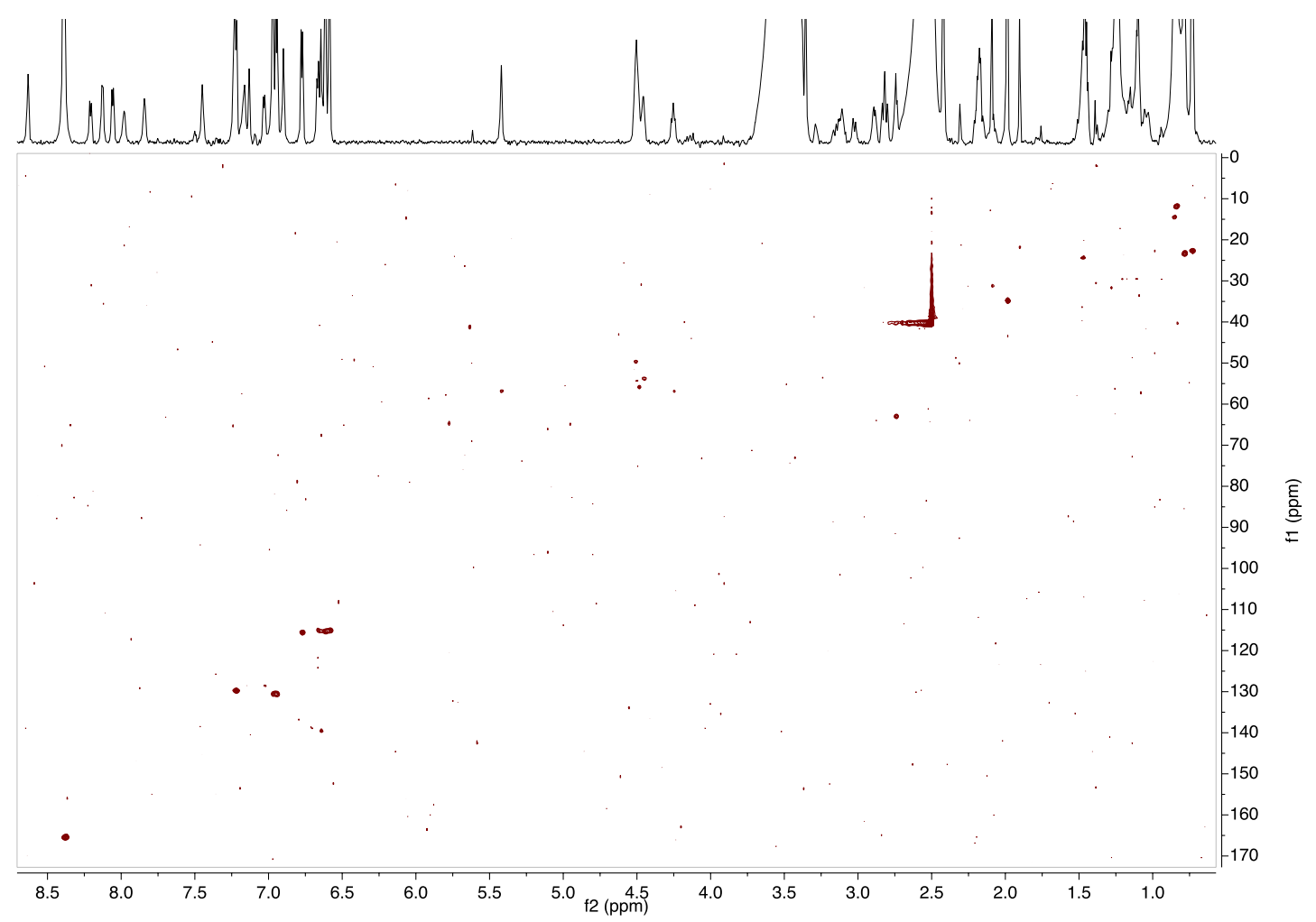

Figure S15. $800 \mathrm{MHz} \mathrm{HSQC}$ spectra of 7 in $\left(\mathrm{CD}_{3}\right)_{2} \mathrm{SO}$ (top). 


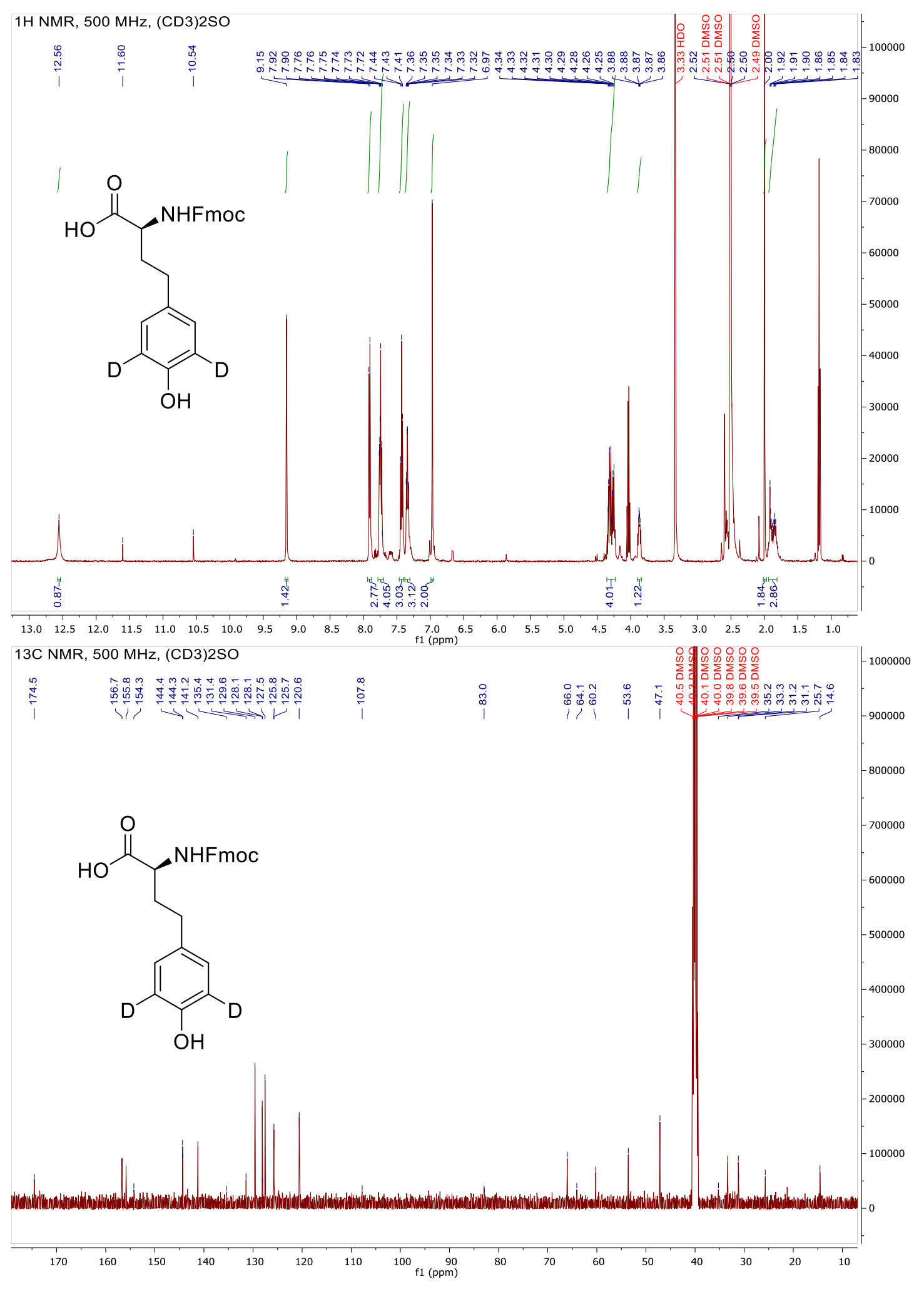

Figure S16. ${ }^{1} \mathrm{H}$ NMR spectrum (top) and ${ }^{13} \mathrm{C}$ NMR spectrum (bottom) of $N$-Fmoc-L-3,5- ${ }^{2} \mathrm{H}_{2}$ homotyrosine. 

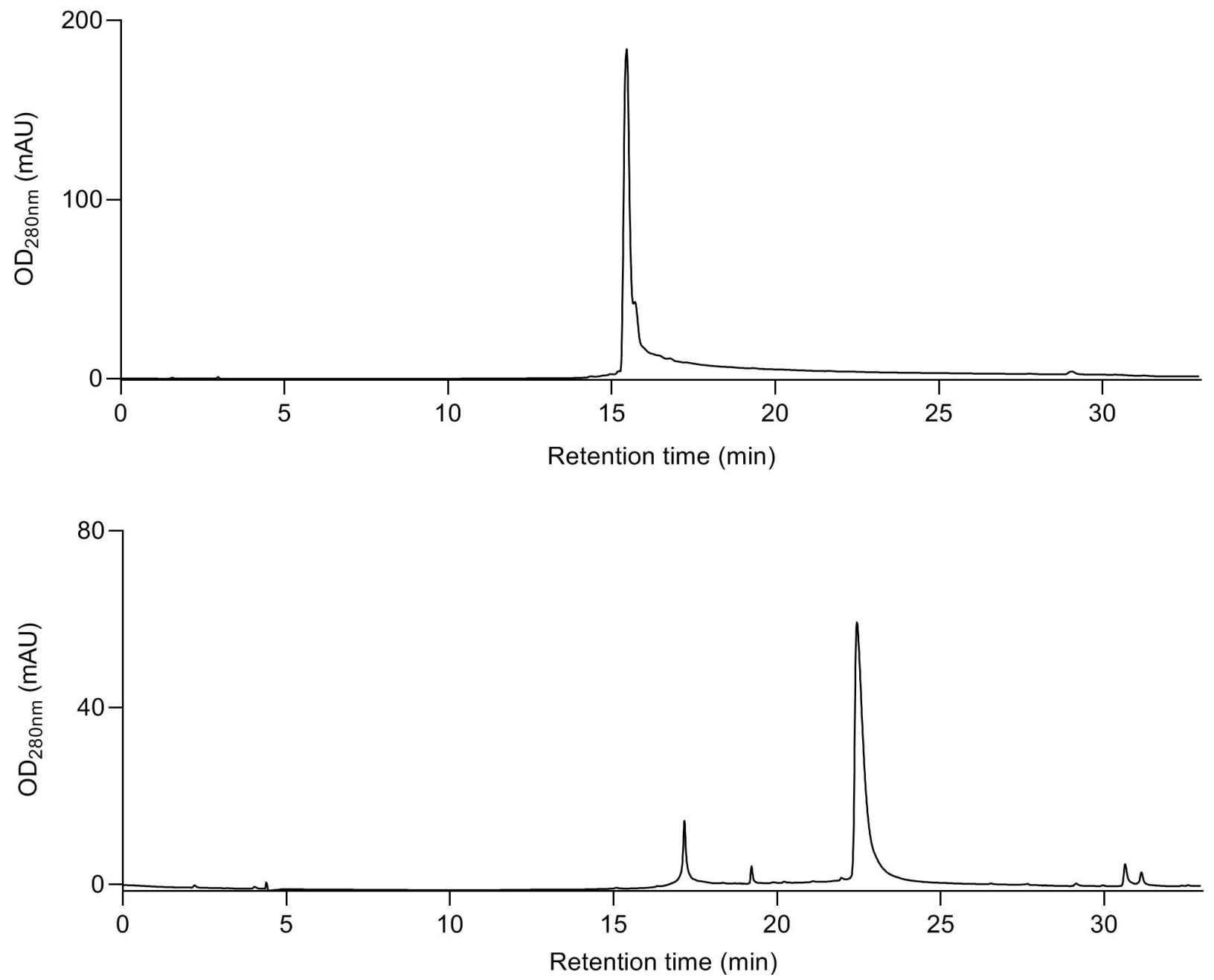

Figure S17. HPLC-MS analysis of pure ortho- ${ }^{2} \mathrm{H}_{2}$-homotyrosine as AA2 and D-Hpg as AA4 (precursor to $\mathbf{1 1}, \mathbf{1 2}$ ) as a 7 mer hydrazide (top) and as a CoA thioester adduct (bottom). 

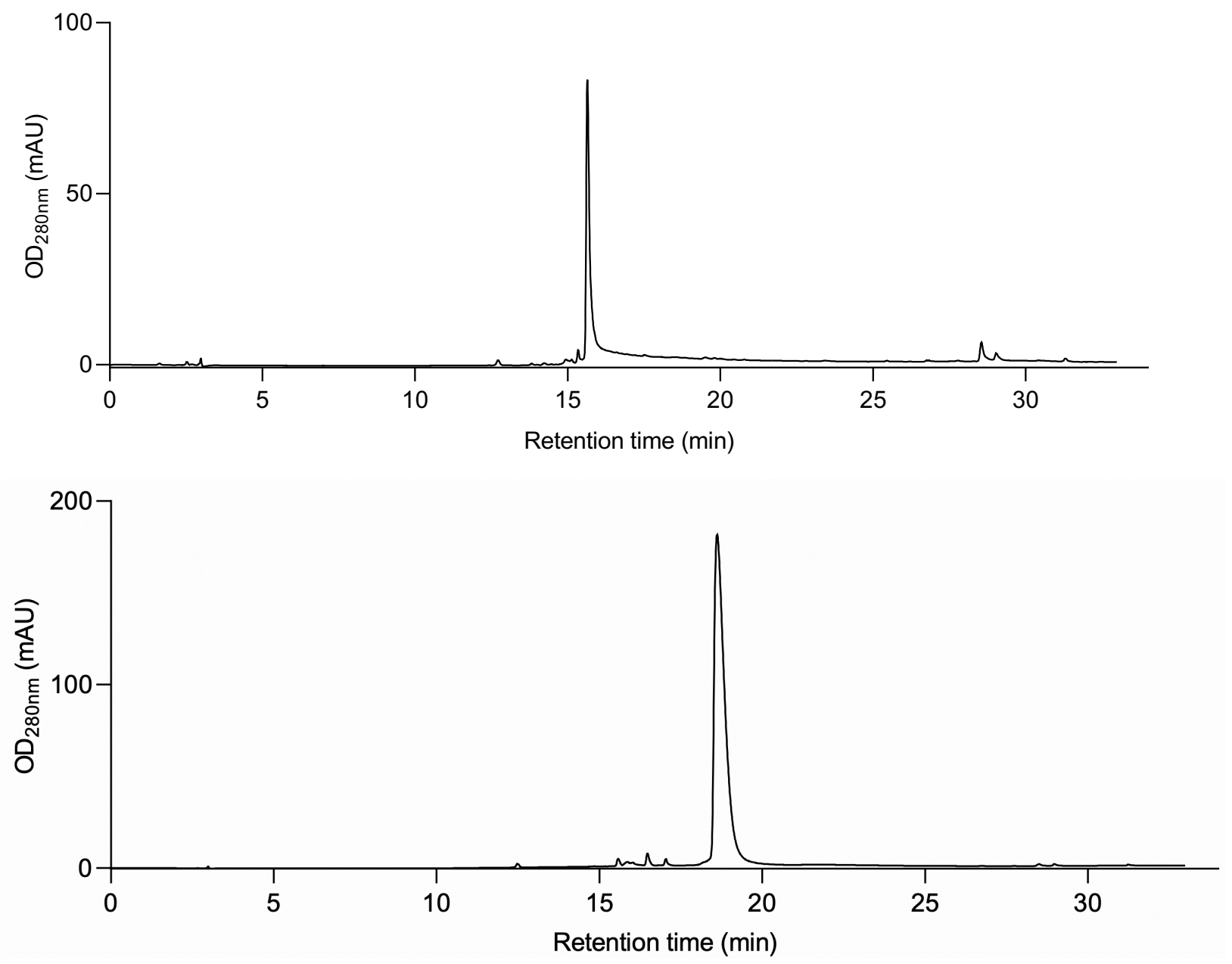

Figure S18. HPLC-MS analysis of pure peptide containing L-homotyrosine as AA2 and ortho${ }^{2} \mathrm{H}_{2}$-D-Hpg as AA4 (precursor to $\mathbf{1 3}, \mathbf{1 4}$ ) as a 7 mer hydrazide (top) and as a CoA thioester adduct (bottom). 

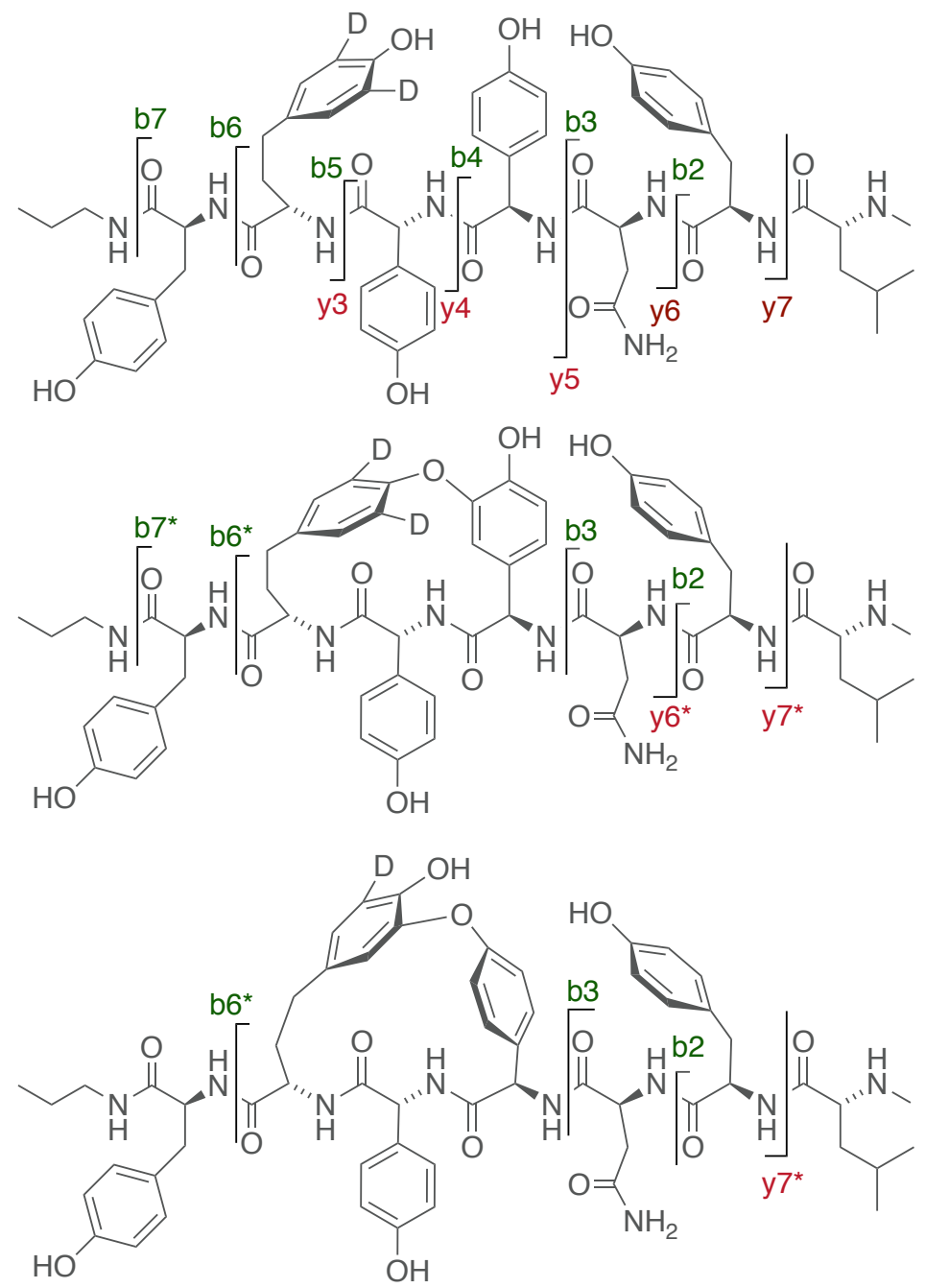

Figure S19. HR-MS/MS for peptide substrate containing ortho $-{ }^{2} \mathrm{H}_{2}-\mathrm{L}$-homotyrosine as AA2 and D-Hpg as AA4 and its products $(\mathbf{1 1}, \mathbf{1 2})$ upon reaction with OxyB. 

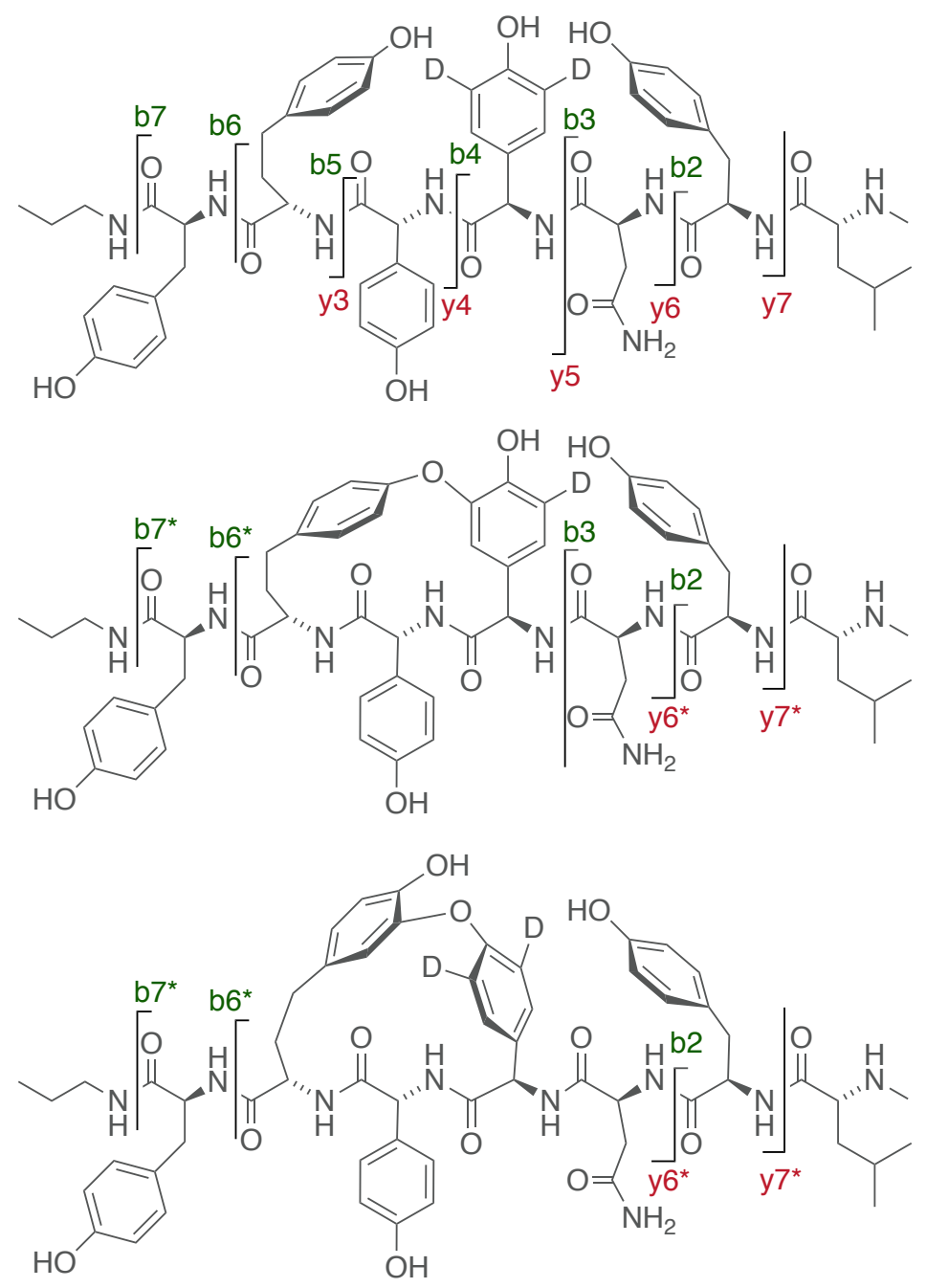

Figure S20. HR-MS/MS for peptide substrate containing L-homotyrosine as AA2 and ortho- ${ }^{2} \mathrm{H}_{2}$ D-Hpg as AA4 and its products $(\mathbf{1 3}, \mathbf{1 4})$ upon reaction with OxyB. 
A

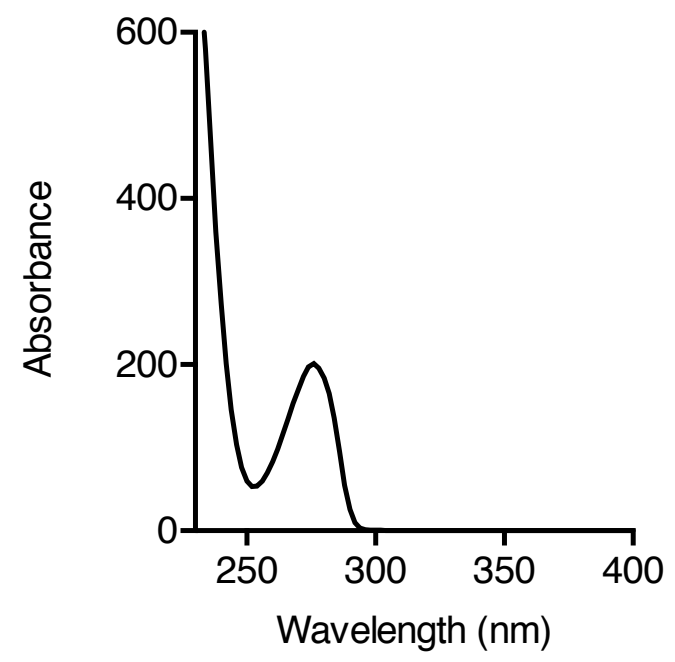

C

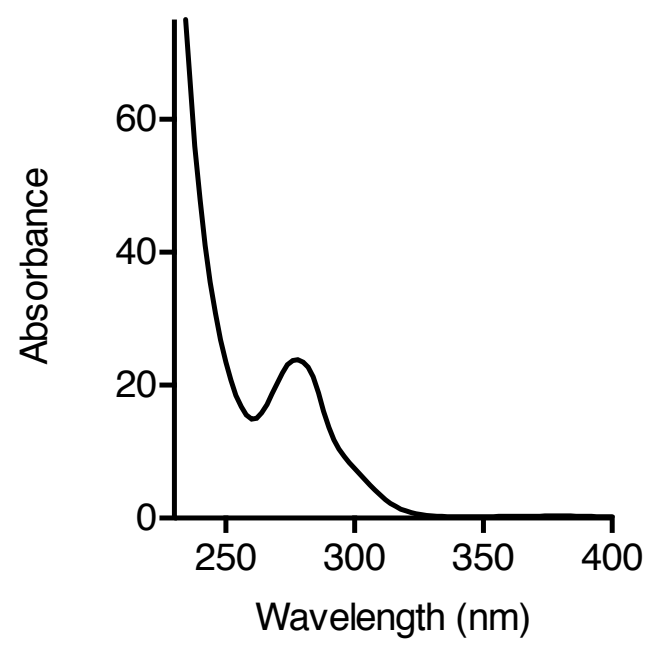

B

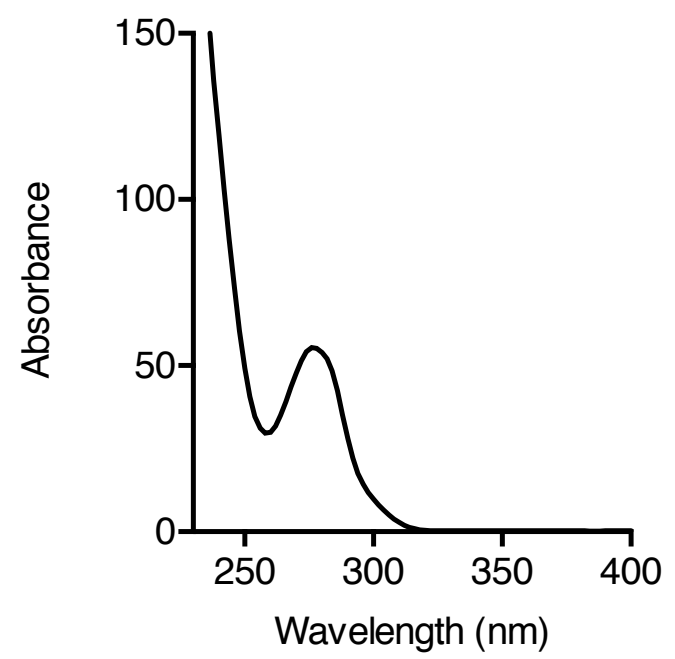

Figure S21. UV-Vis spectra for A) substrate 8; B) product 11; C) product 12. 

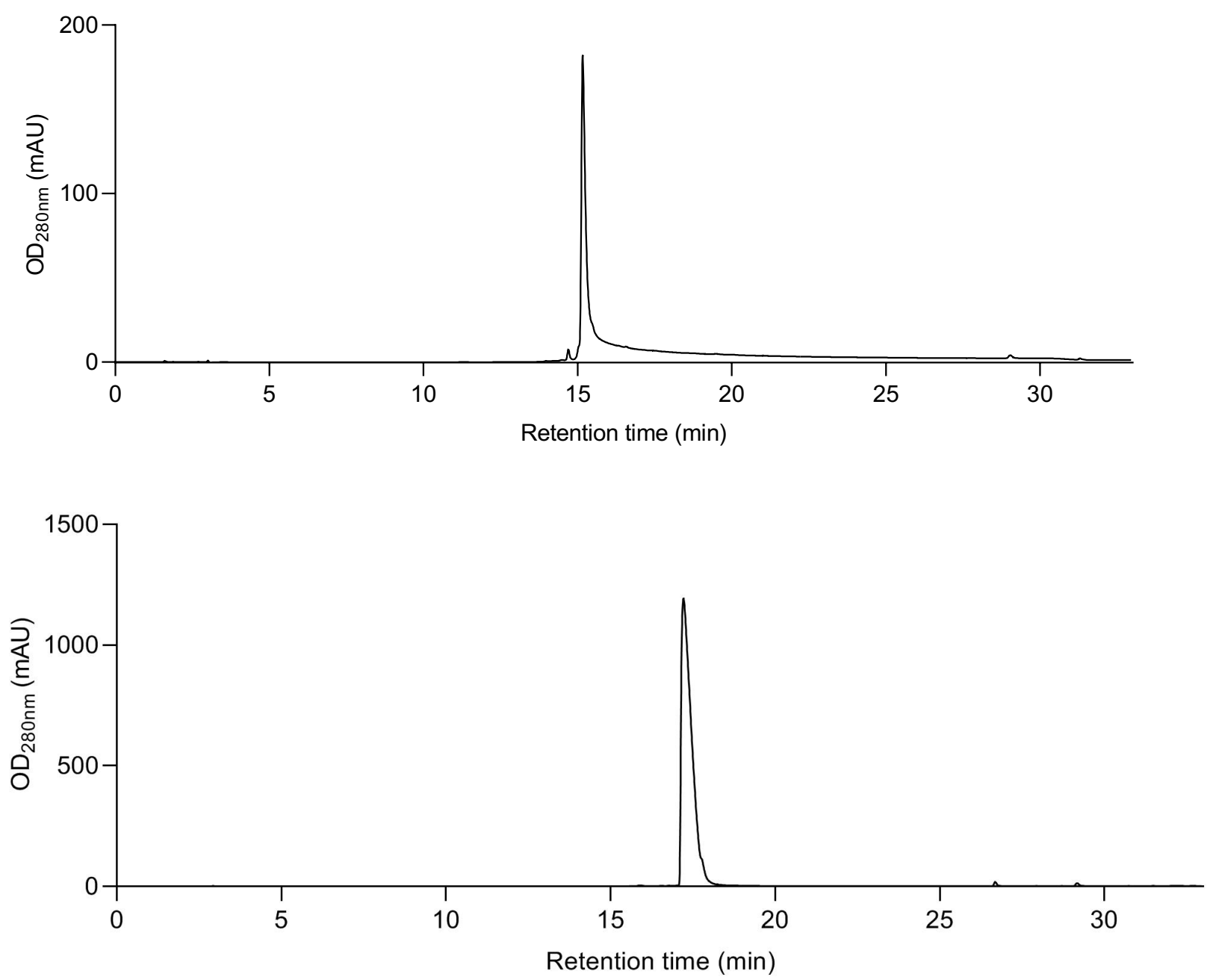

Figure S22. HPLC-MS analysis of pure $\mathbf{1 5}$ as a 7 mer hydrazide (top) and as a CoA thioester adduct (bottom). 

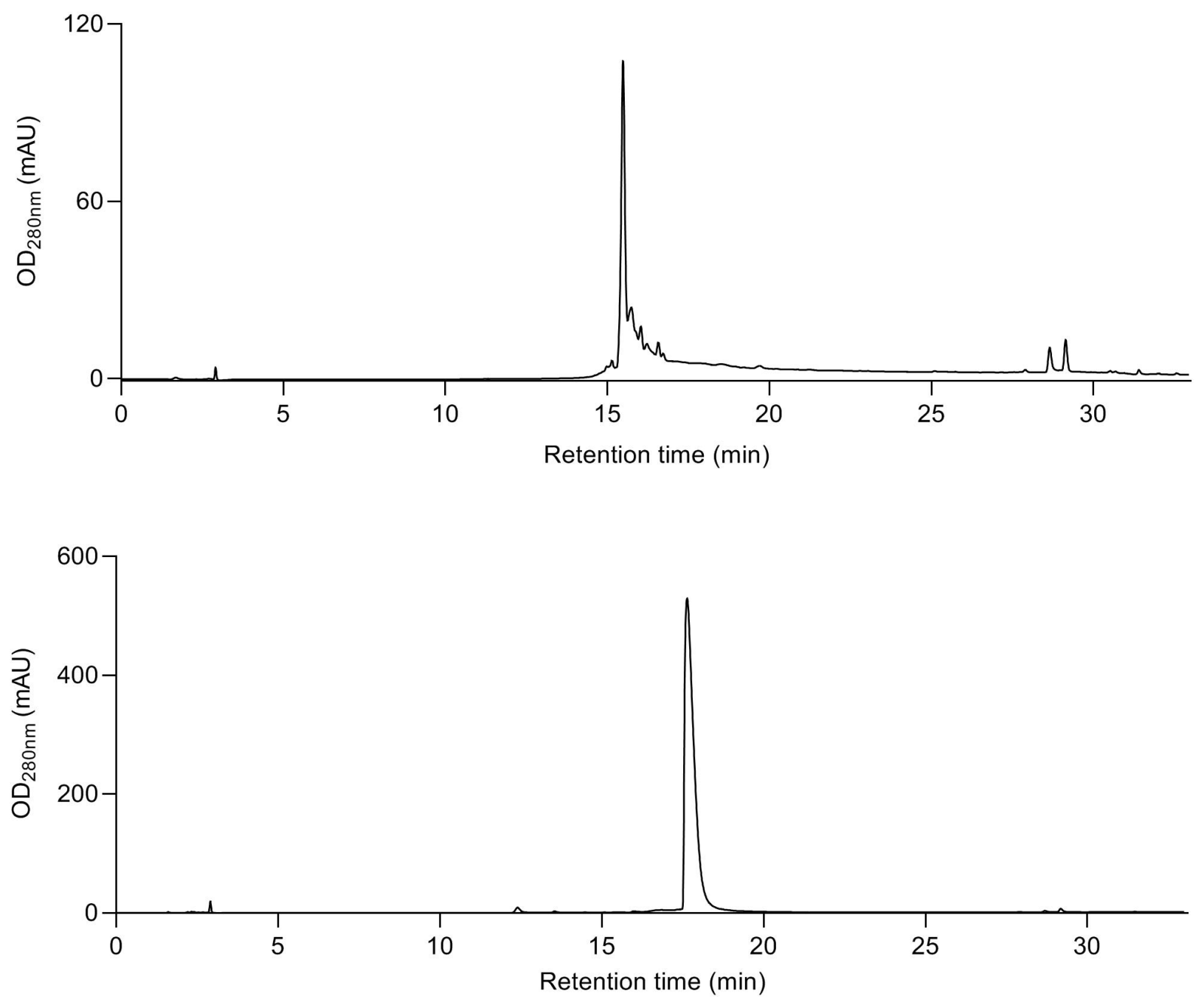

Figure S23. HPLC-MS analysis of pure $\mathbf{1 7}$ as a $\mathbf{7 m e r}$ hydrazide (top) and as a CoA thioester adduct (bottom). 

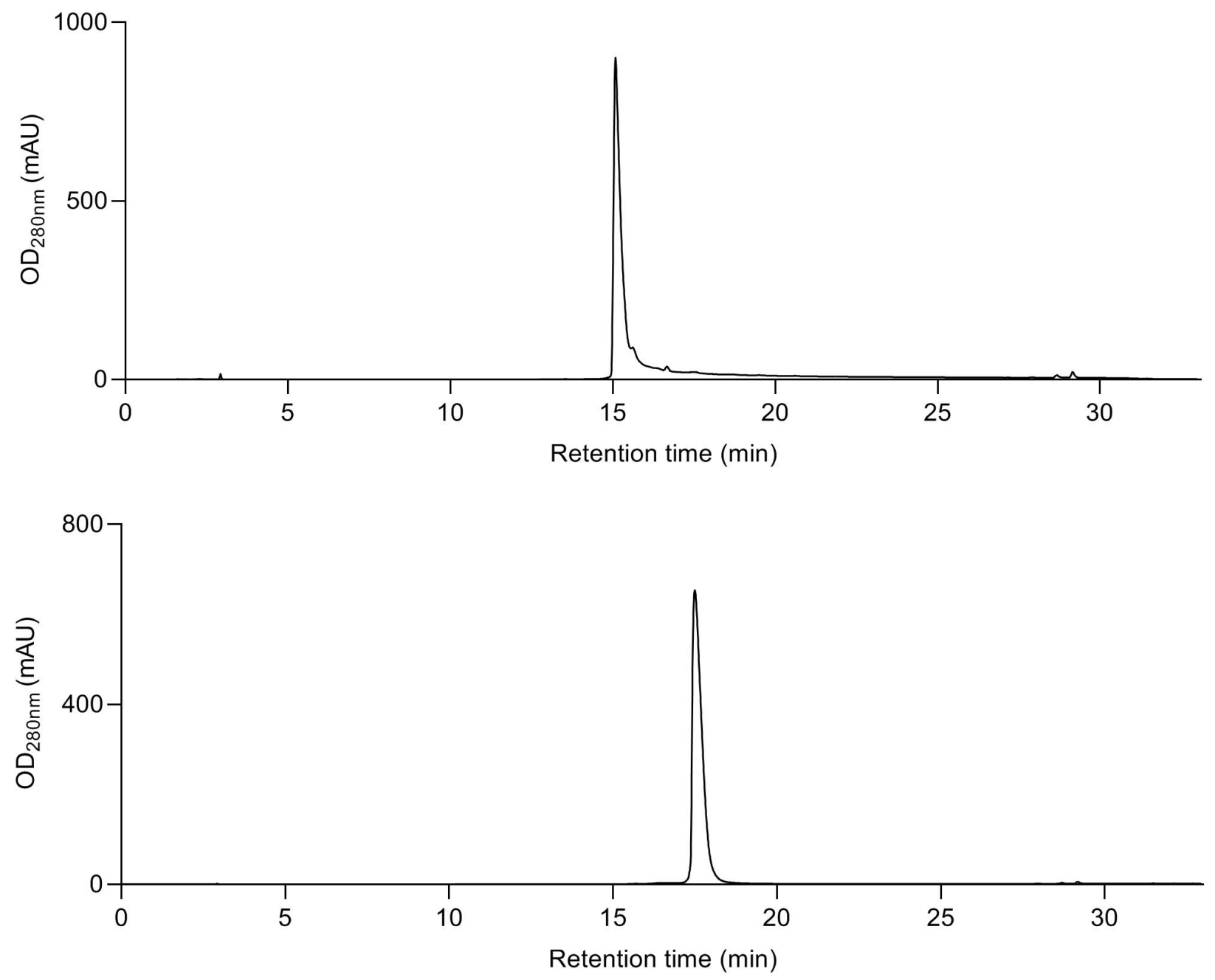

Figure S24. HPLC-MS analysis of pure $\mathbf{2 0}$ as a 7 mer hydrazide (top) and as a CoA thioester adduct (bottom). 

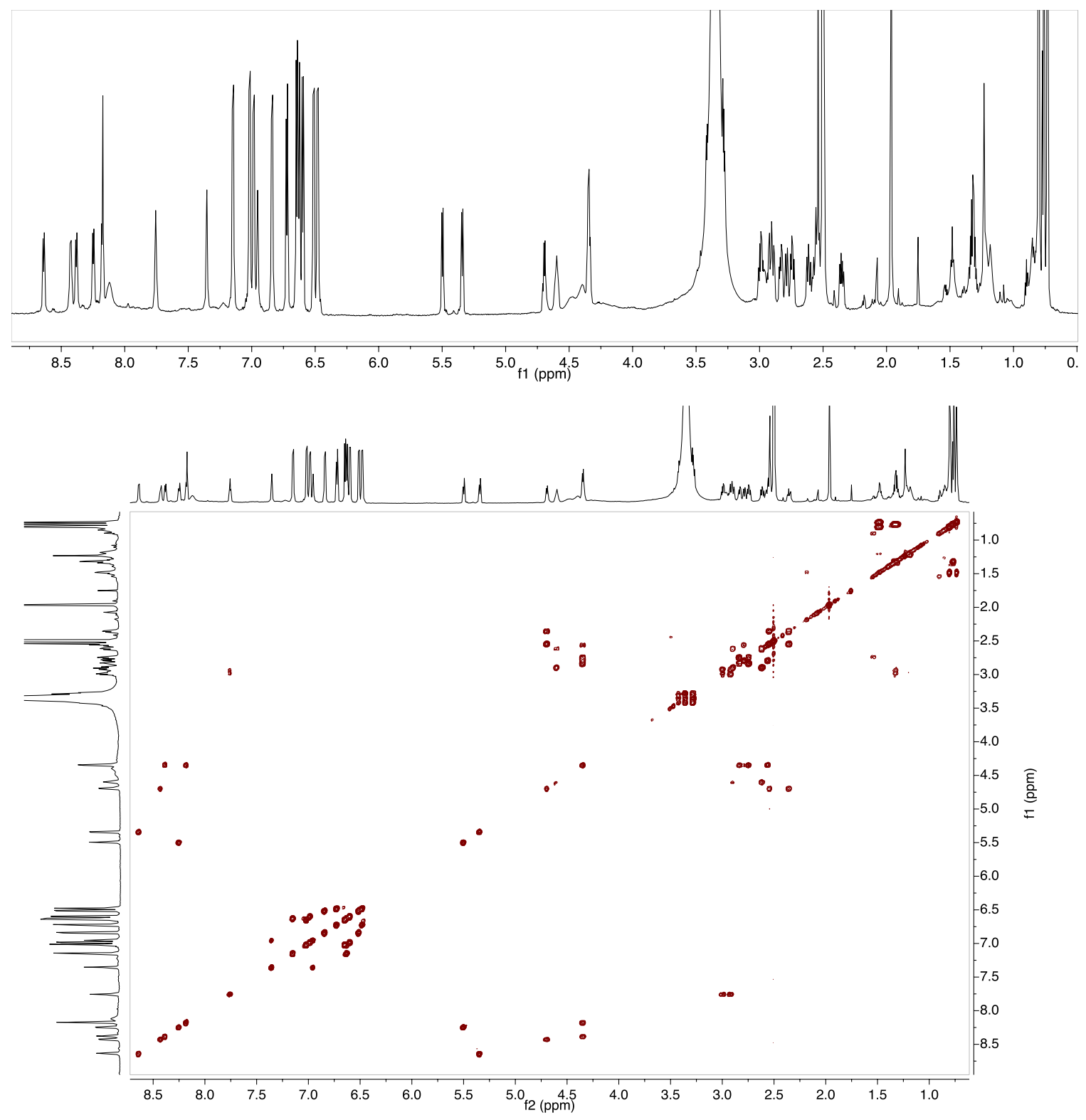

Figure S25. $800 \mathrm{MHz}{ }^{1} \mathrm{H}$ NMR of 15 in $\left(\mathrm{CD}_{3}\right)_{2} \mathrm{SO}$ (top). $800 \mathrm{MHz} \mathrm{COSY}$ spectra of 15 in $\left(\mathrm{CD}_{3}\right)_{2} \mathrm{SO}$ (bottom). 

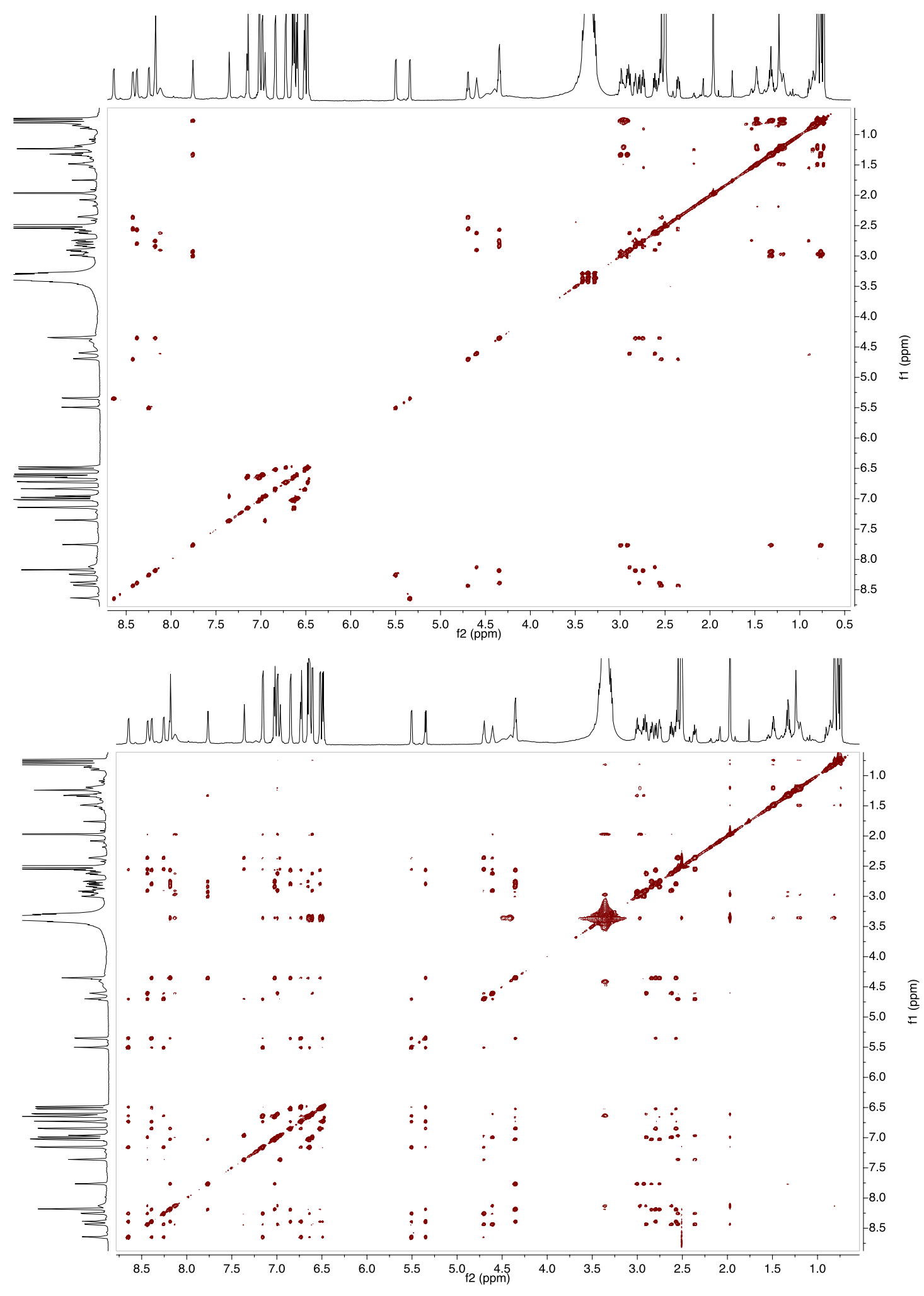

Figure S26. $800 \mathrm{MHz}$ TOCSY spectra of 15 in (CD $)_{2} \mathrm{SO}$ (top). $800 \mathrm{MHz}$ NOESY spectra of 15 in $\left(\mathrm{CD}_{3}\right)_{2} \mathrm{SO}$ (bottom). 

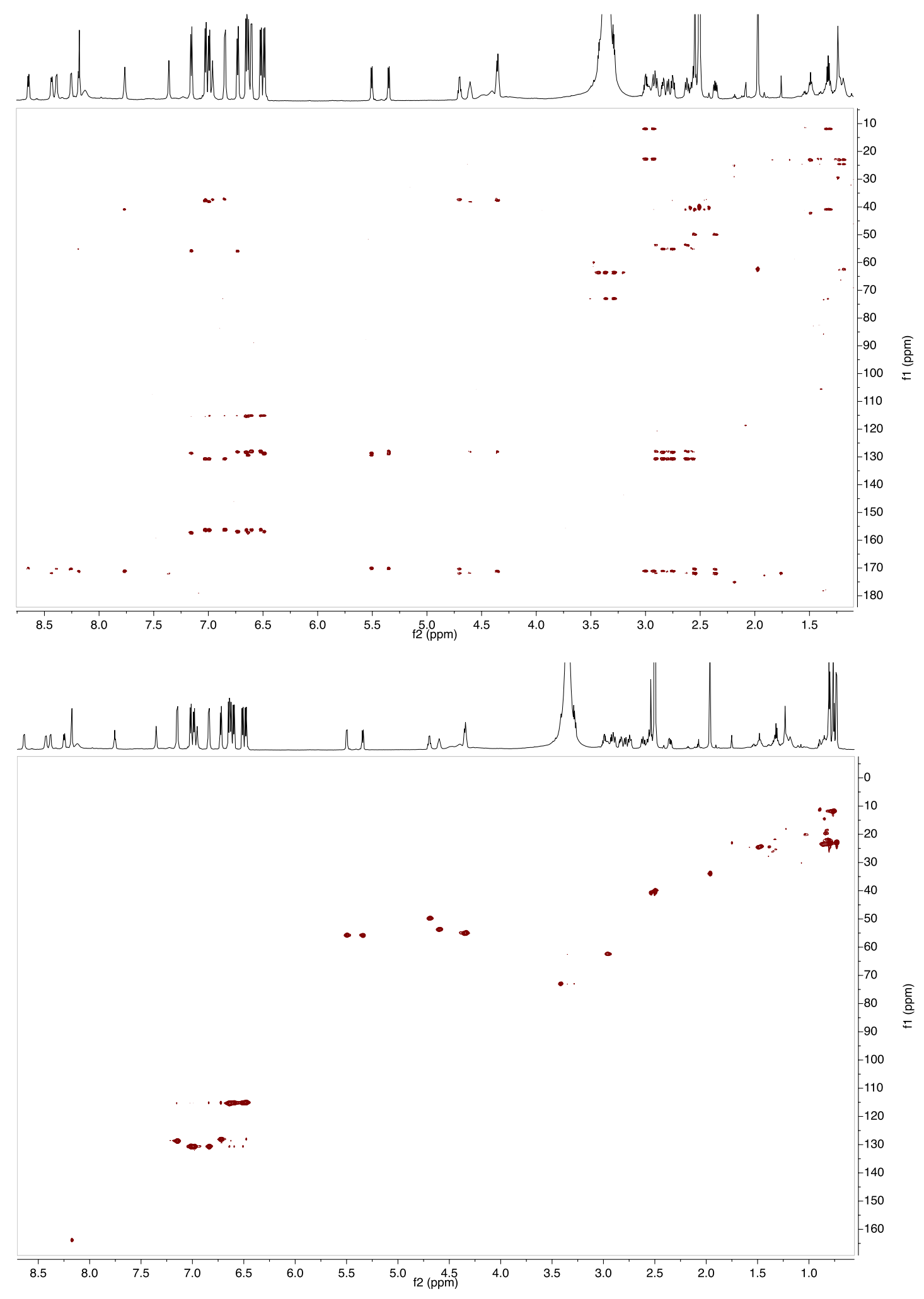

Figure S27. $800 \mathrm{MHz}$ HSQC spectra of 15 in $\left(\mathrm{CD}_{3}\right)_{2} \mathrm{SO}$ (top). $800 \mathrm{MHz} \mathrm{HMBC}$ spectra of 15 in $\left(\mathrm{CD}_{3}\right)_{2} \mathrm{SO}$ (bottom). 

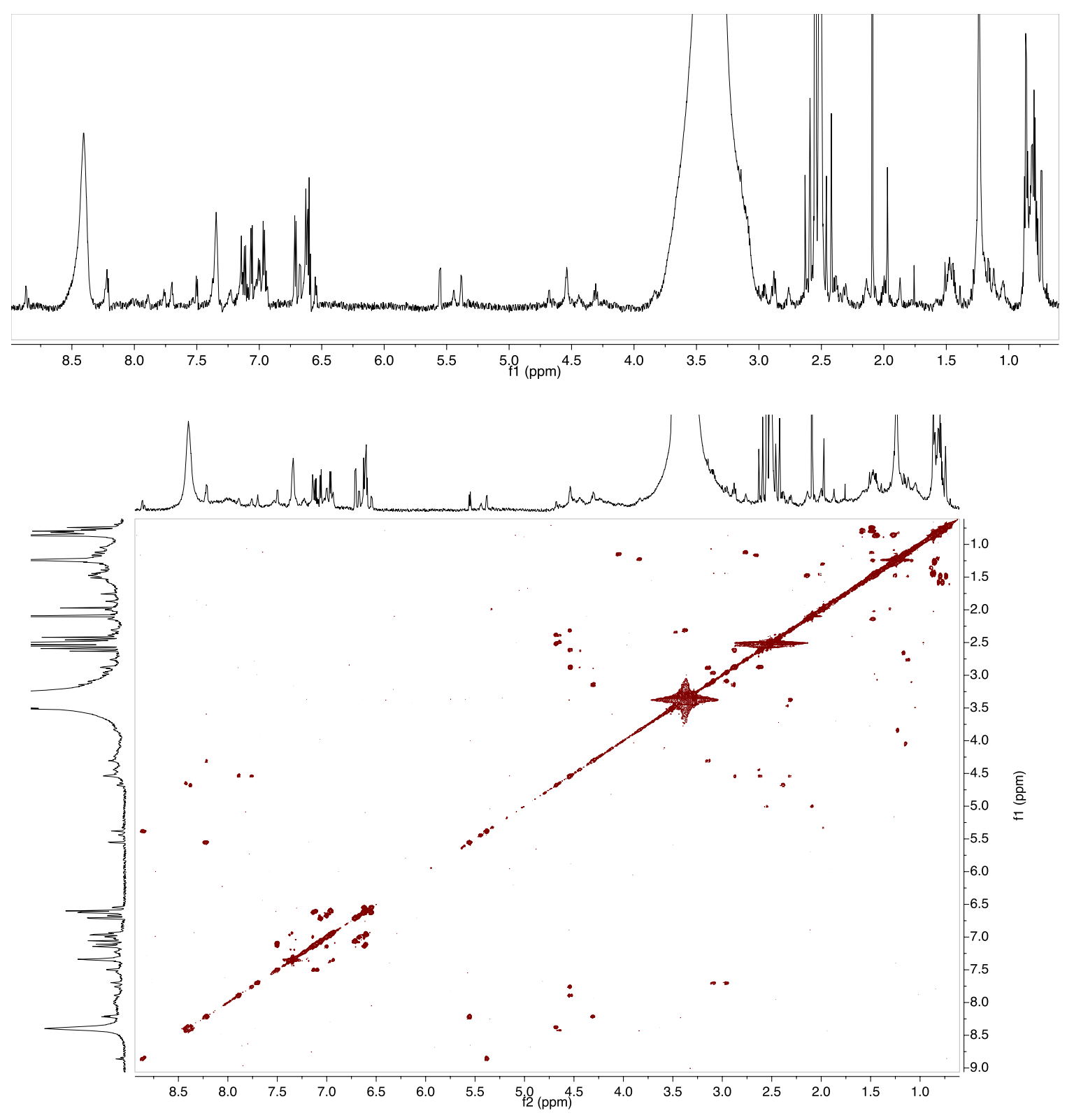

Figure S28. $800 \mathrm{MHz}{ }^{1} \mathrm{H}$ NMR of 16 in $\left(\mathrm{CD}_{3}\right)_{2} \mathrm{SO}$ (top). $800 \mathrm{MHz}$ COSY spectra of 16 in $\left(\mathrm{CD}_{3}\right)_{2} \mathrm{SO}$ (bottom). 

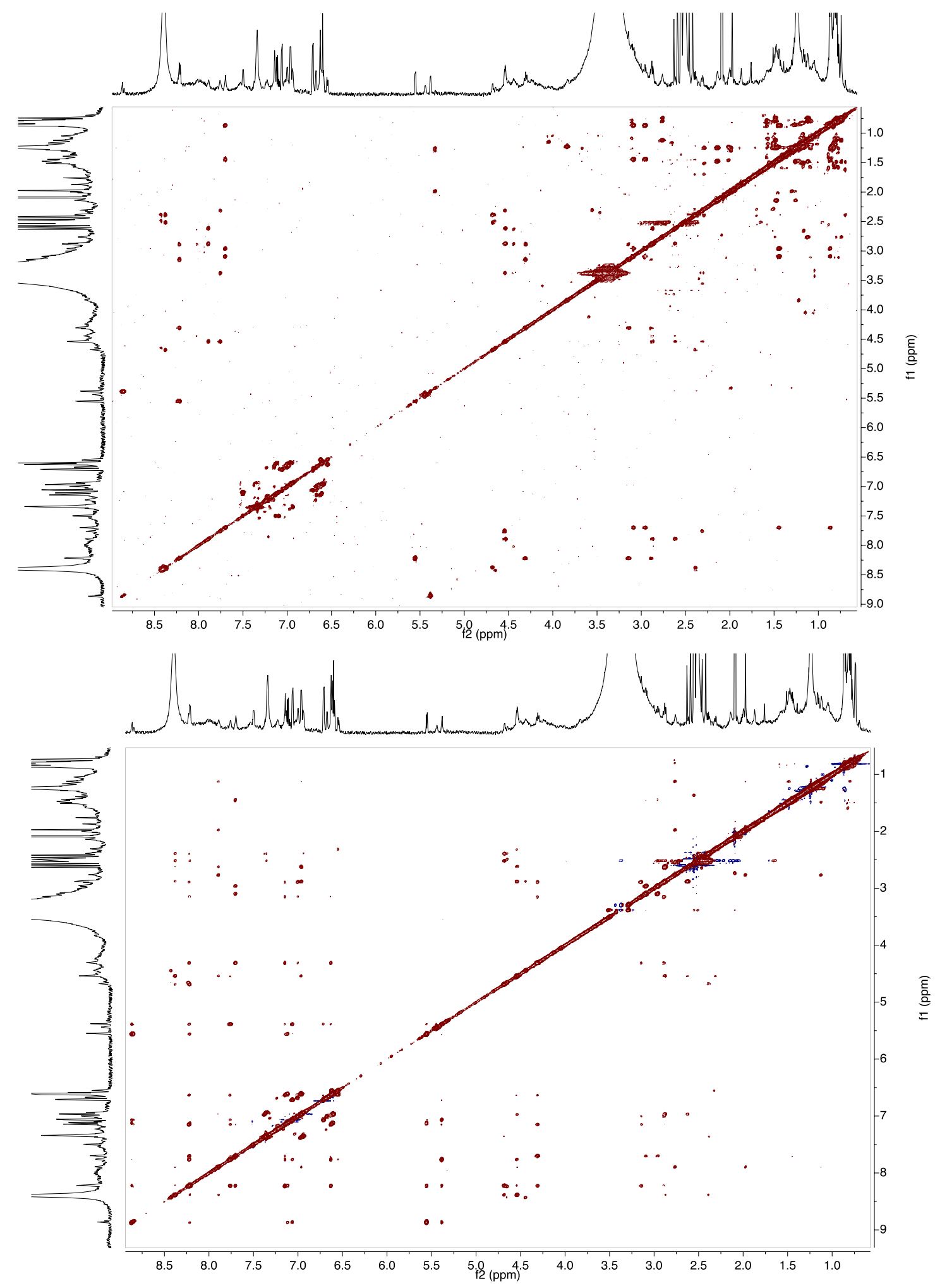

Figure S29. $800 \mathrm{MHz}$ TOCSY spectra of $\mathbf{1 6}$ in $\left(\mathrm{CD}_{3}\right)_{2} \mathrm{SO}$ (top). $800 \mathrm{MHz}$ NOESY spectra of $\mathbf{1 6}$ in $\left(\mathrm{CD}_{3}\right)_{2} \mathrm{SO}$ (bottom). 


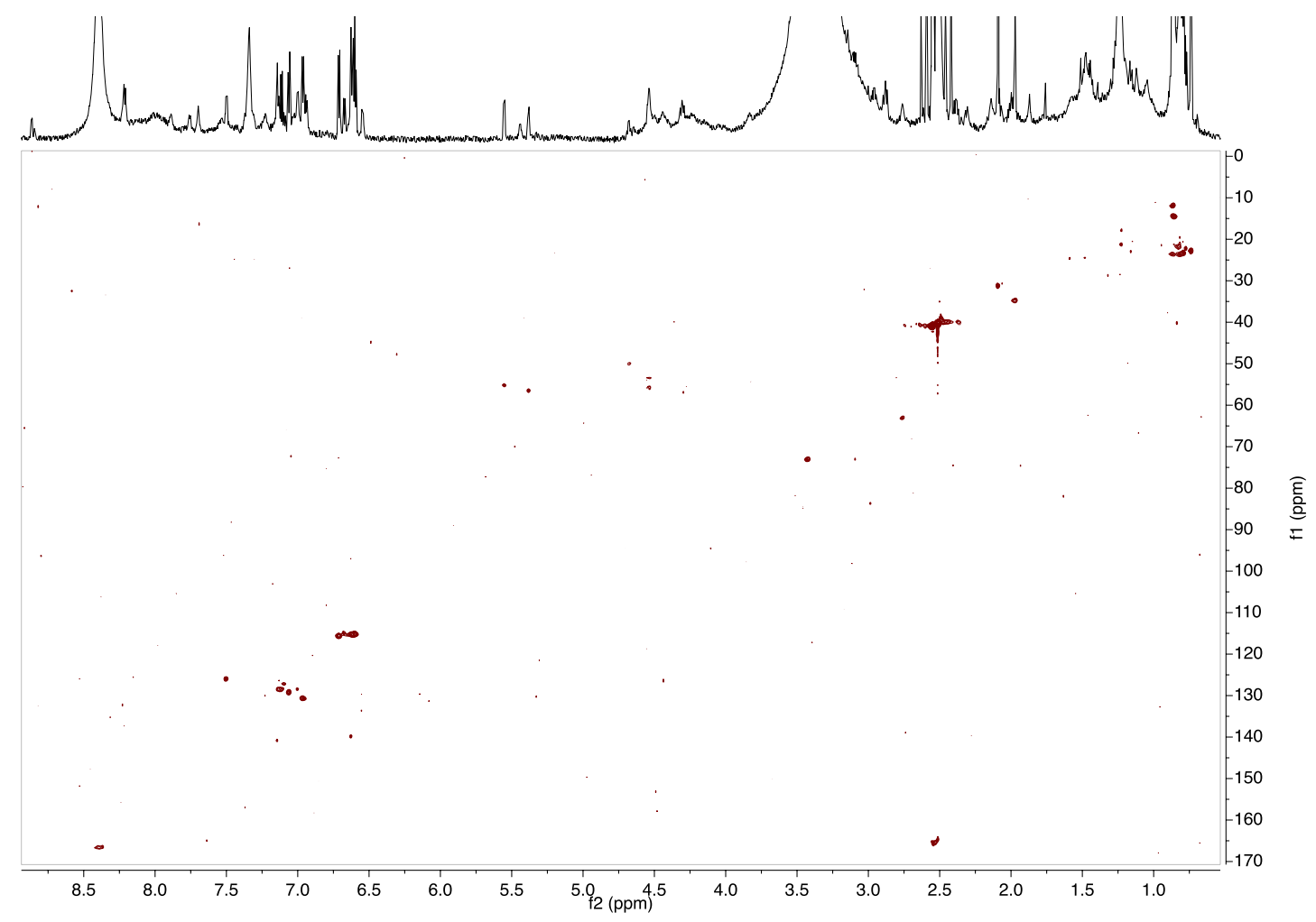

Figure S30. $800 \mathrm{MHz}$ HSQC spectra of 16 in $\left(\mathrm{CD}_{3}\right)_{2} \mathrm{SO}$ (top). 
A

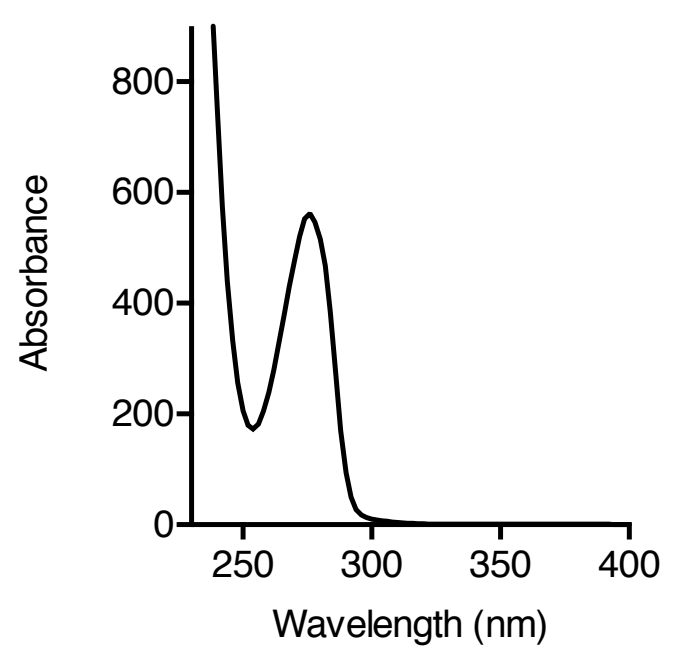

B

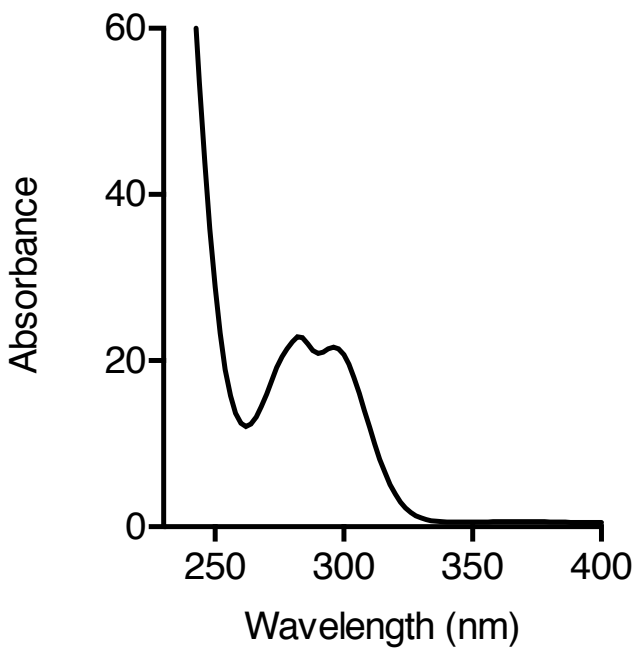

Figure S31. UV-Vis spectra for A) substrate 15; B) product 16. 

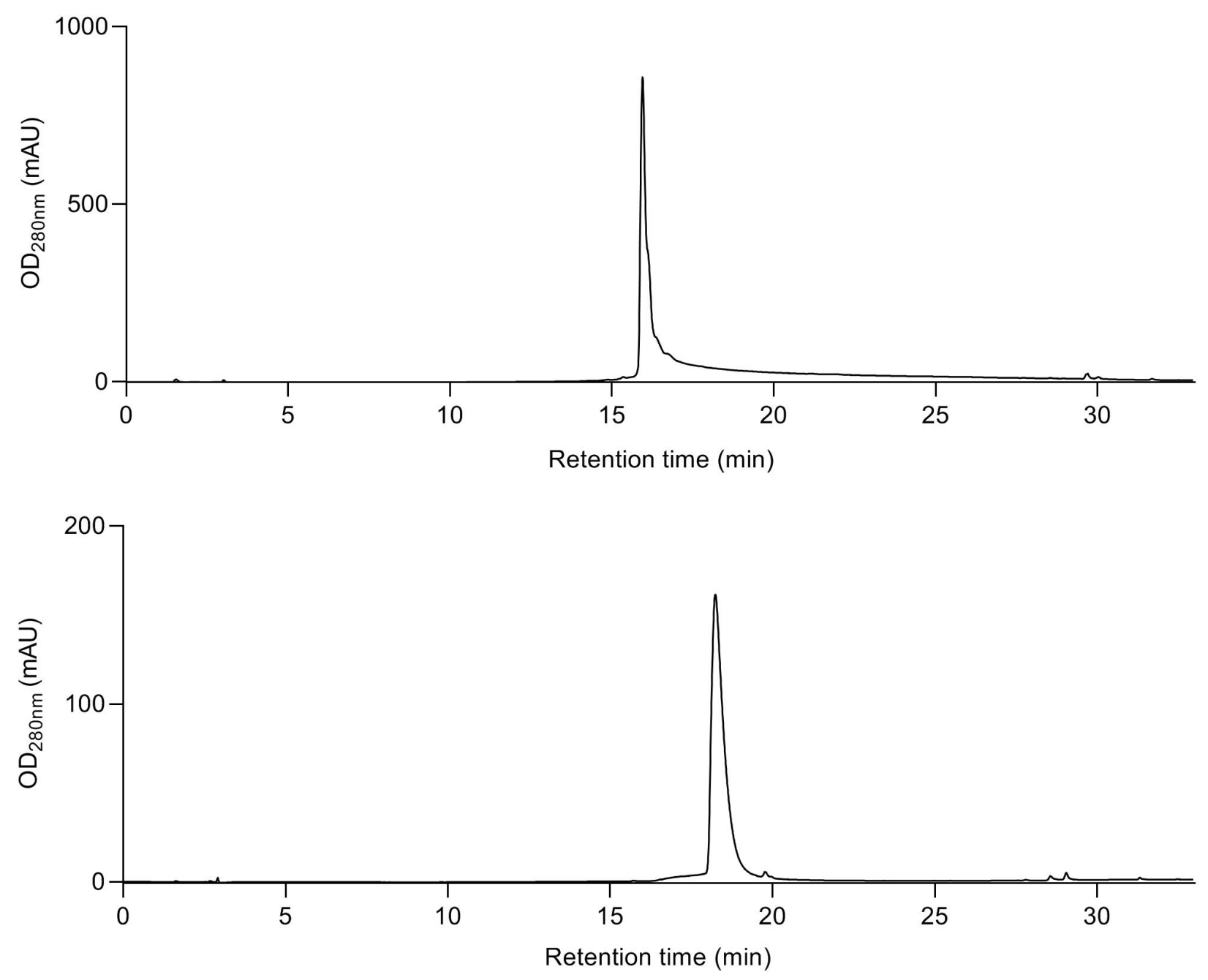

Figure S32. HPLC-MS analysis of pure peptide containing D-tyrosine as AA2 and ortho- ${ }^{2} \mathrm{H}_{2}-\mathrm{D}-$ Hpg as AA4 (precursor to 19) as a 7mer hydrazide (top) and as a CoA thioester adduct (bottom). 


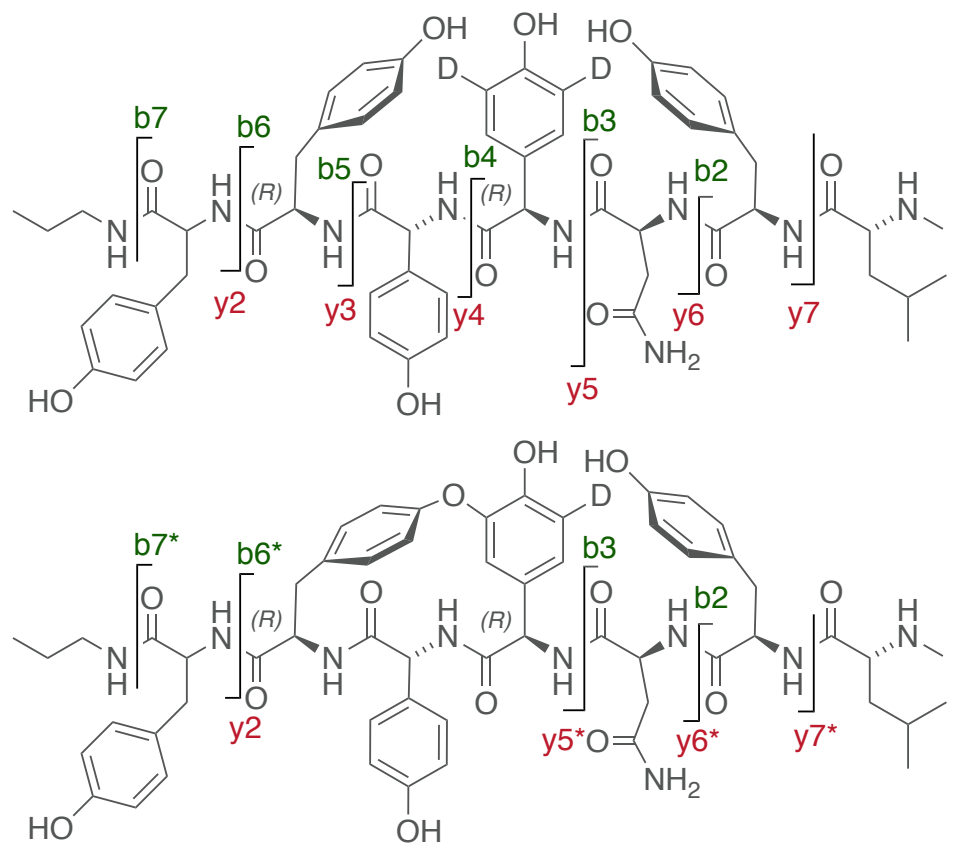

Figure S33. HR-MS/MS for peptide substrate containing D-tyrosine as AA2 and ortho- ${ }^{2} \mathrm{H}_{2}-\mathrm{D}-$ Hpg as AA4 and its product (19) upon reaction with OxyB. 


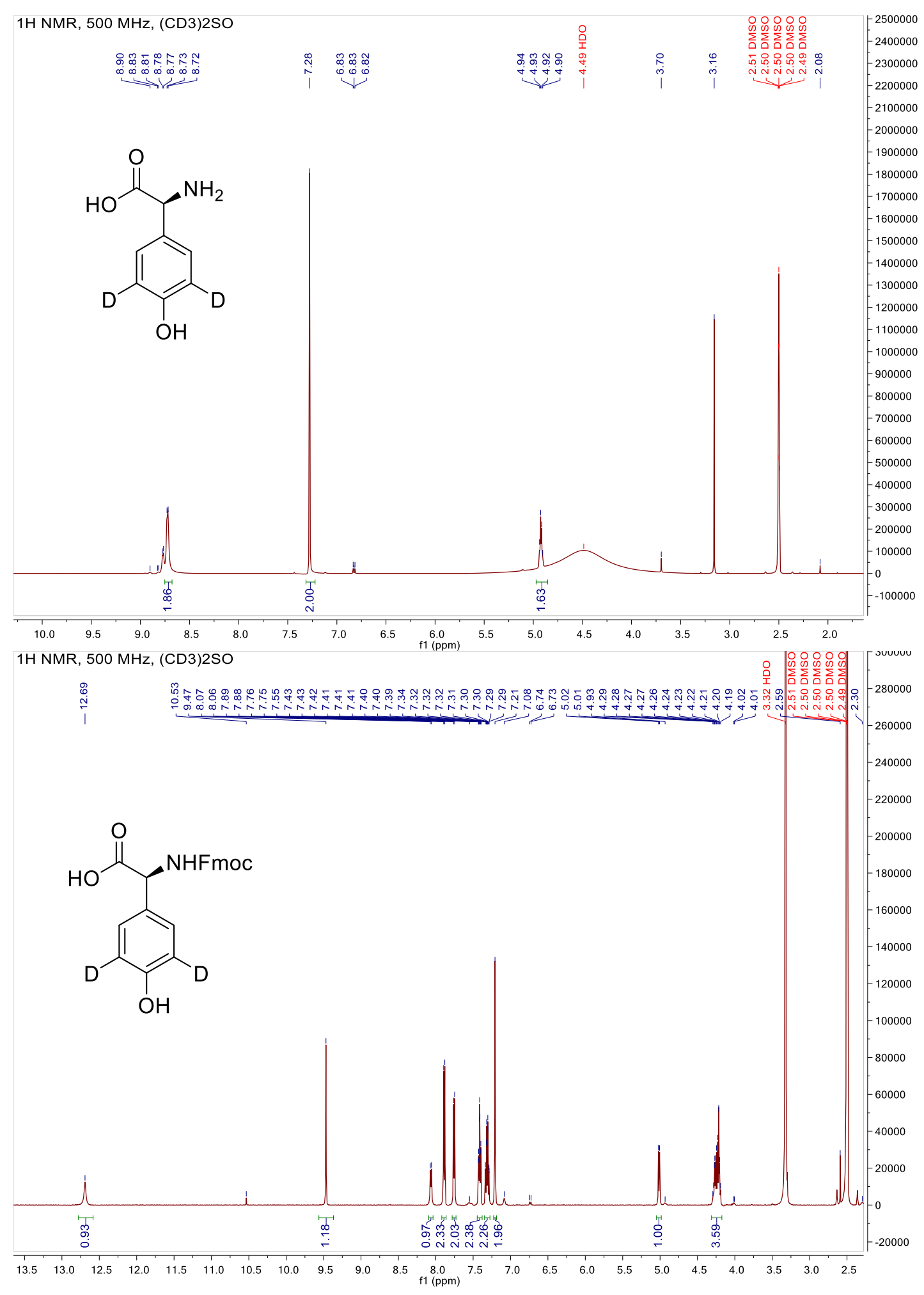

Figure S34. ${ }^{1} \mathrm{H}$ NMR spectrum of L-3,5- ${ }^{2} \mathrm{H}_{2}-4$-hydroxyphenylglycine (top) and $N$-Fmoc- L-3,5${ }^{2} \mathrm{H}_{2}$-4-hydroxyphenylglycine (bottom). 

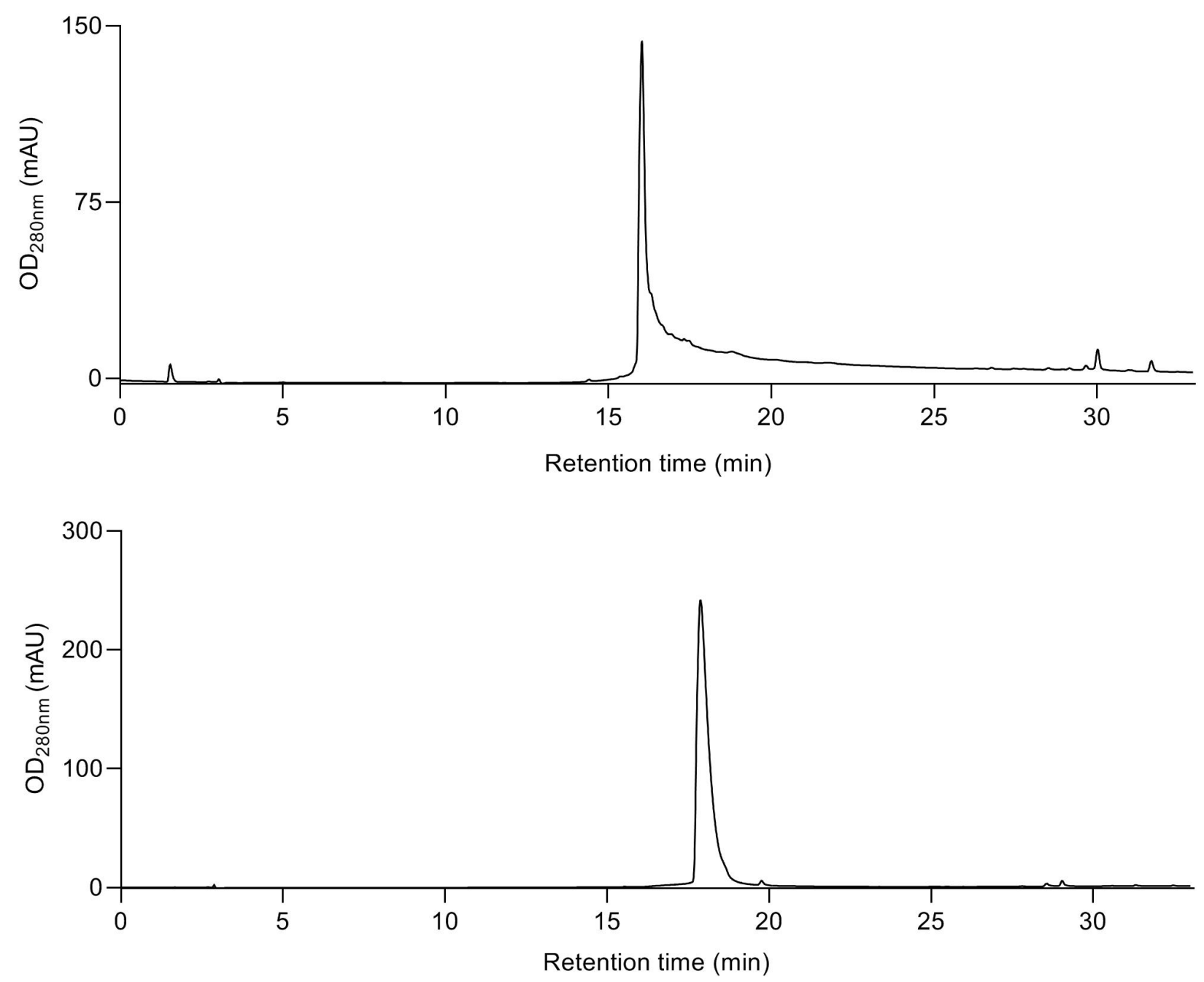

Figure S35. HPLC-MS analysis of pure peptide containing D-Tyr2 as AA2 and ortho- ${ }^{2} \mathrm{H}_{2}-\mathrm{L}-\mathrm{Hpg} 4$ (precursor to $\mathbf{2 3}, \mathbf{2 4}$ ) as a 7 mer hydrazide (top) and as a CoA thioester adduct (bottom). 

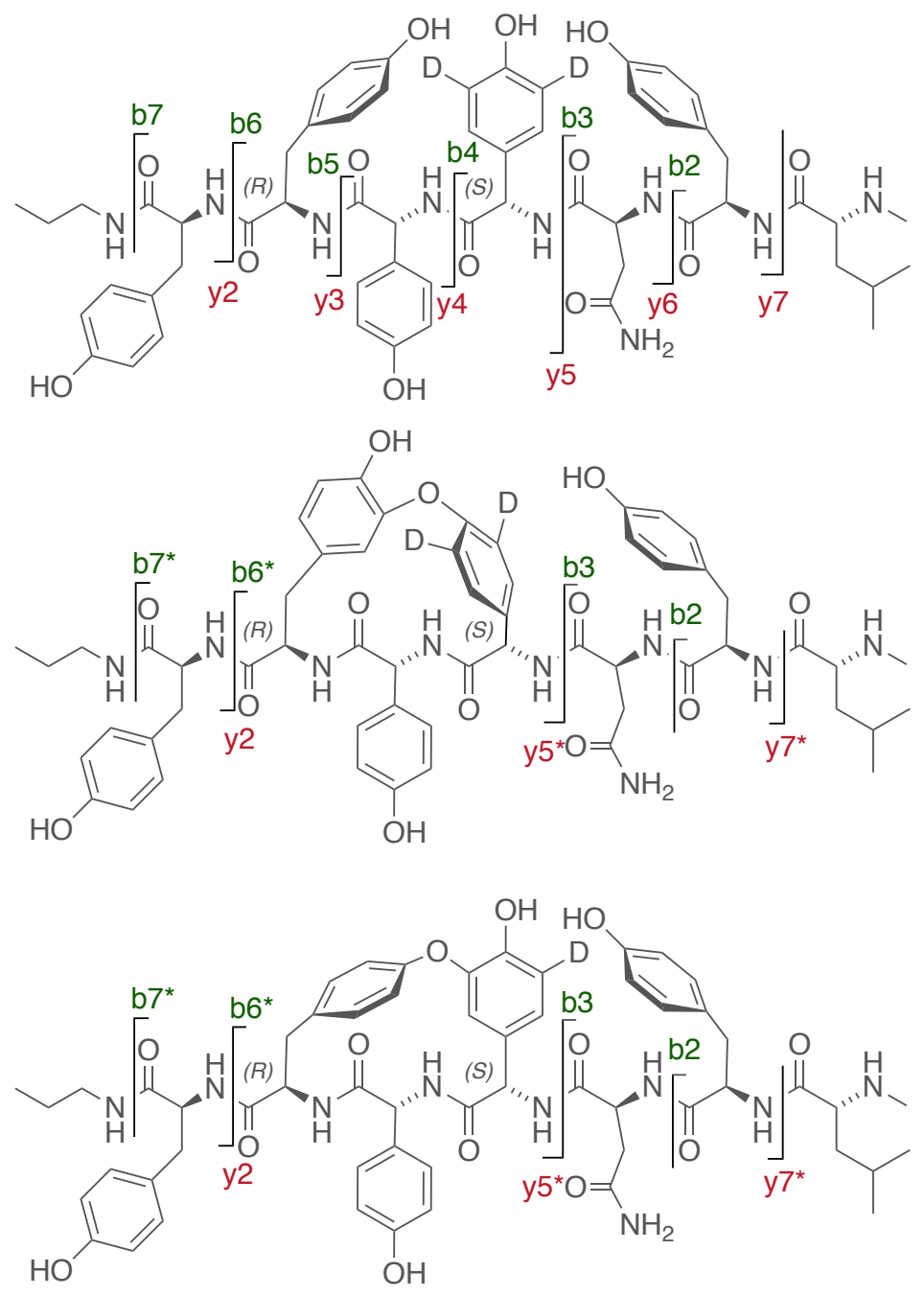

Figure S36. HR-MS/MS data for starting material containing D-Tyr as AA2 and $3,5-{ }^{2} \mathrm{H}_{2}-\mathrm{L}-\mathrm{Hpg}$ as AA4 and products $\mathbf{2 3 ,} \mathbf{2 4}$. 
A

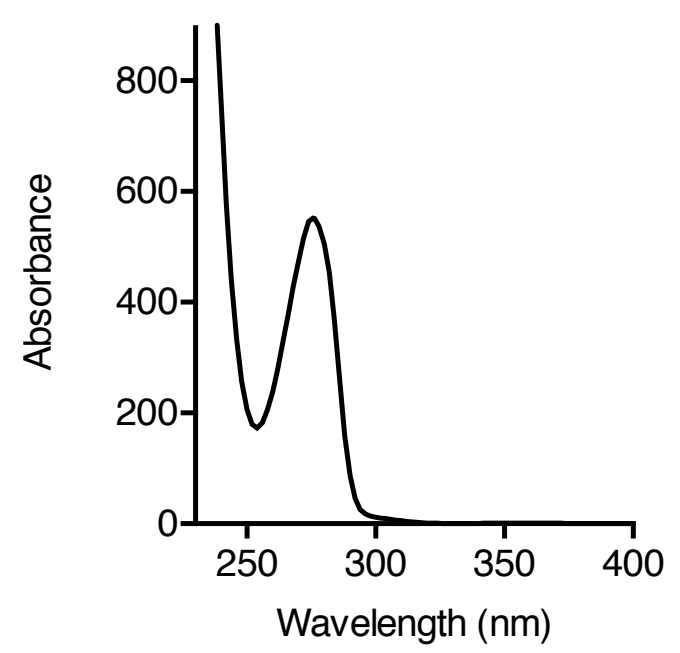

B

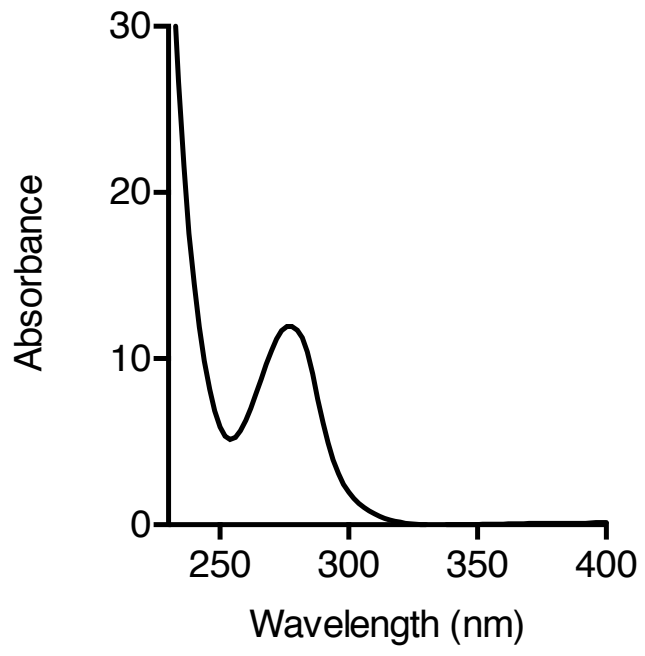

Figure S37. UV-Vis spectrum of A) substrate 20; B) products 21, 22. 

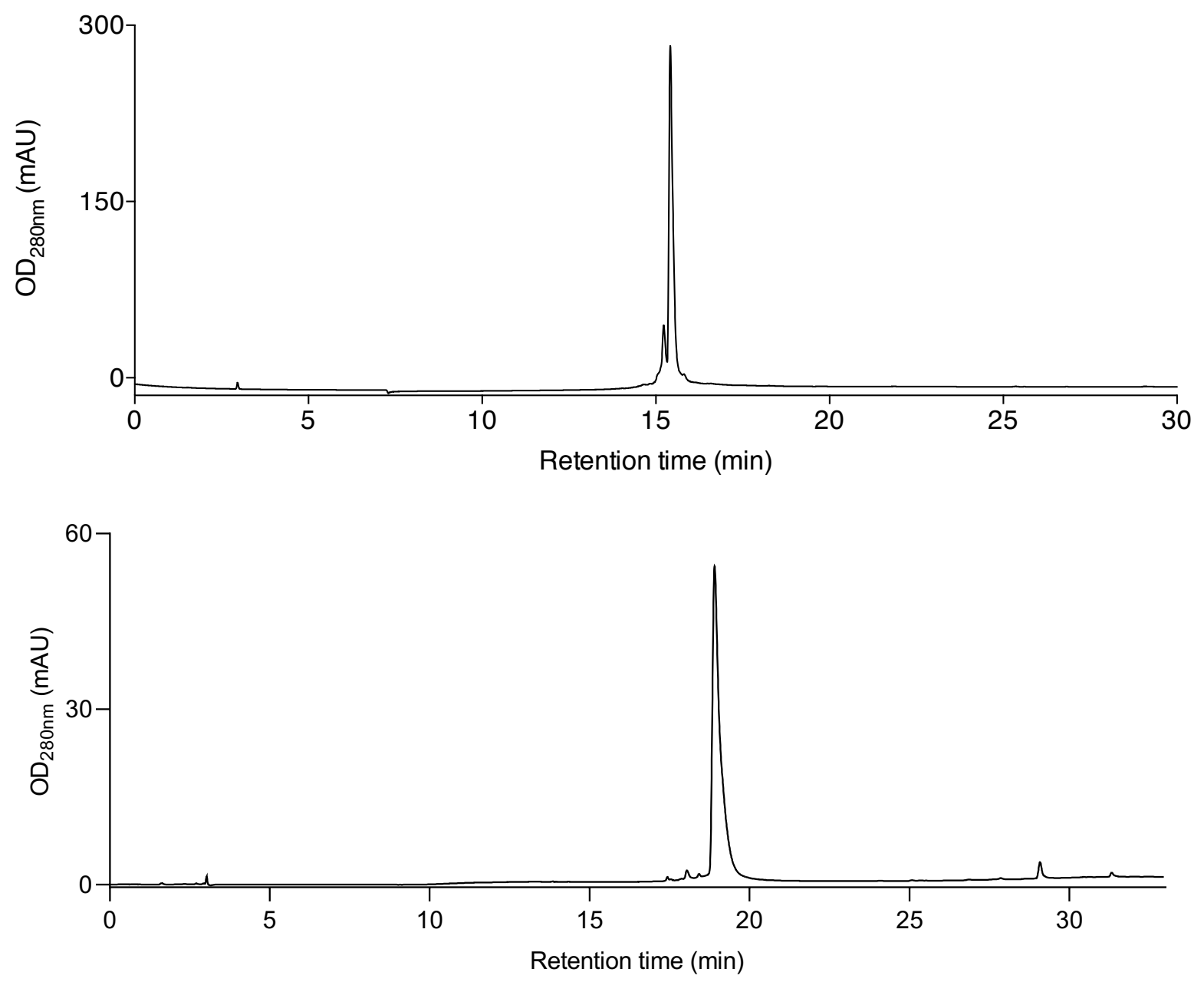

Figure S38. HPLC-MS analysis of pure 25 as a 7 mer hydrazide (top) and as a CoA thioester adduct (bottom). 

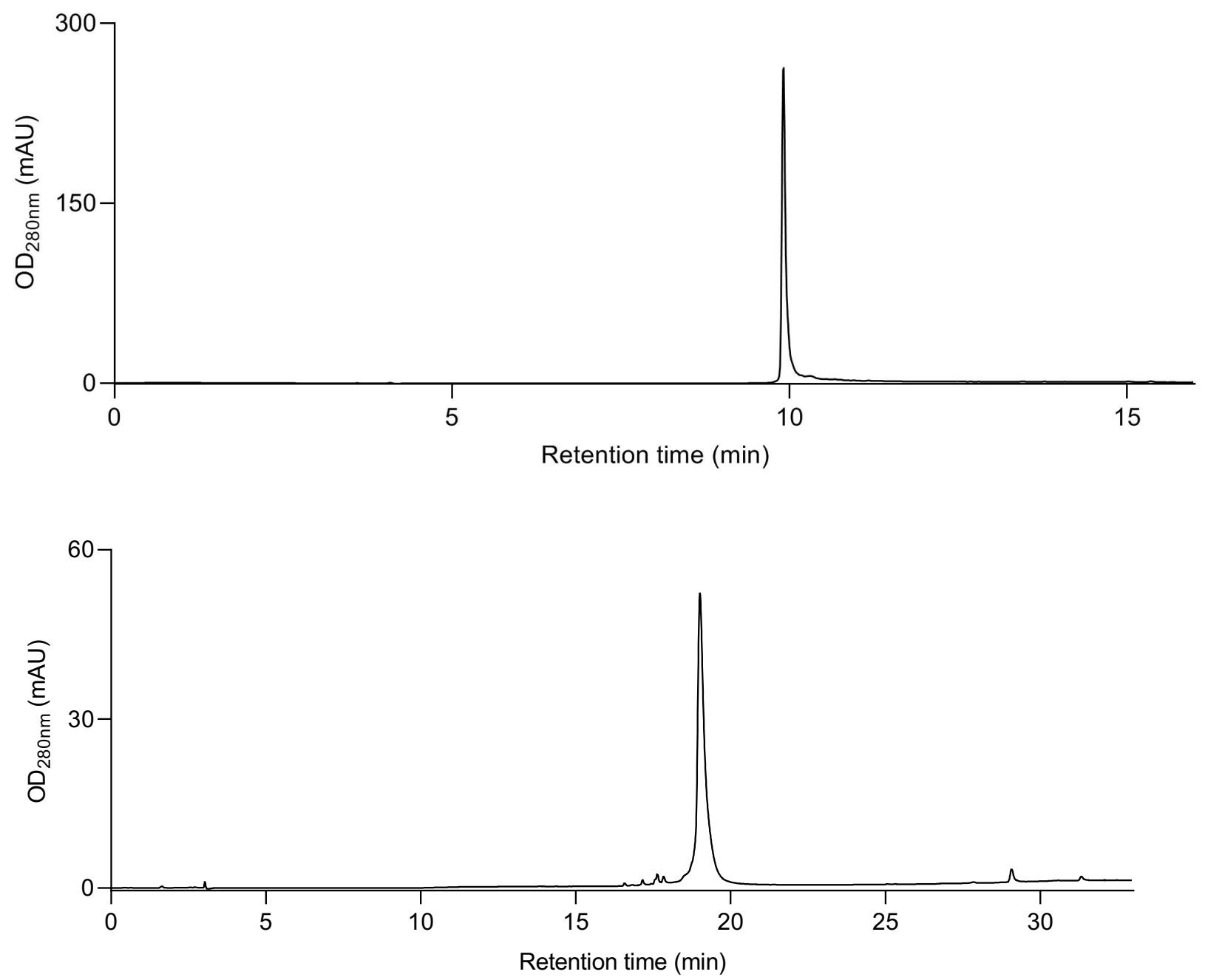

Figure S39. HPLC-MS analysis of pure $\mathbf{2 7}$ as a 7 mer hydrazide (top) and as a CoA thioester adduct (bottom). 

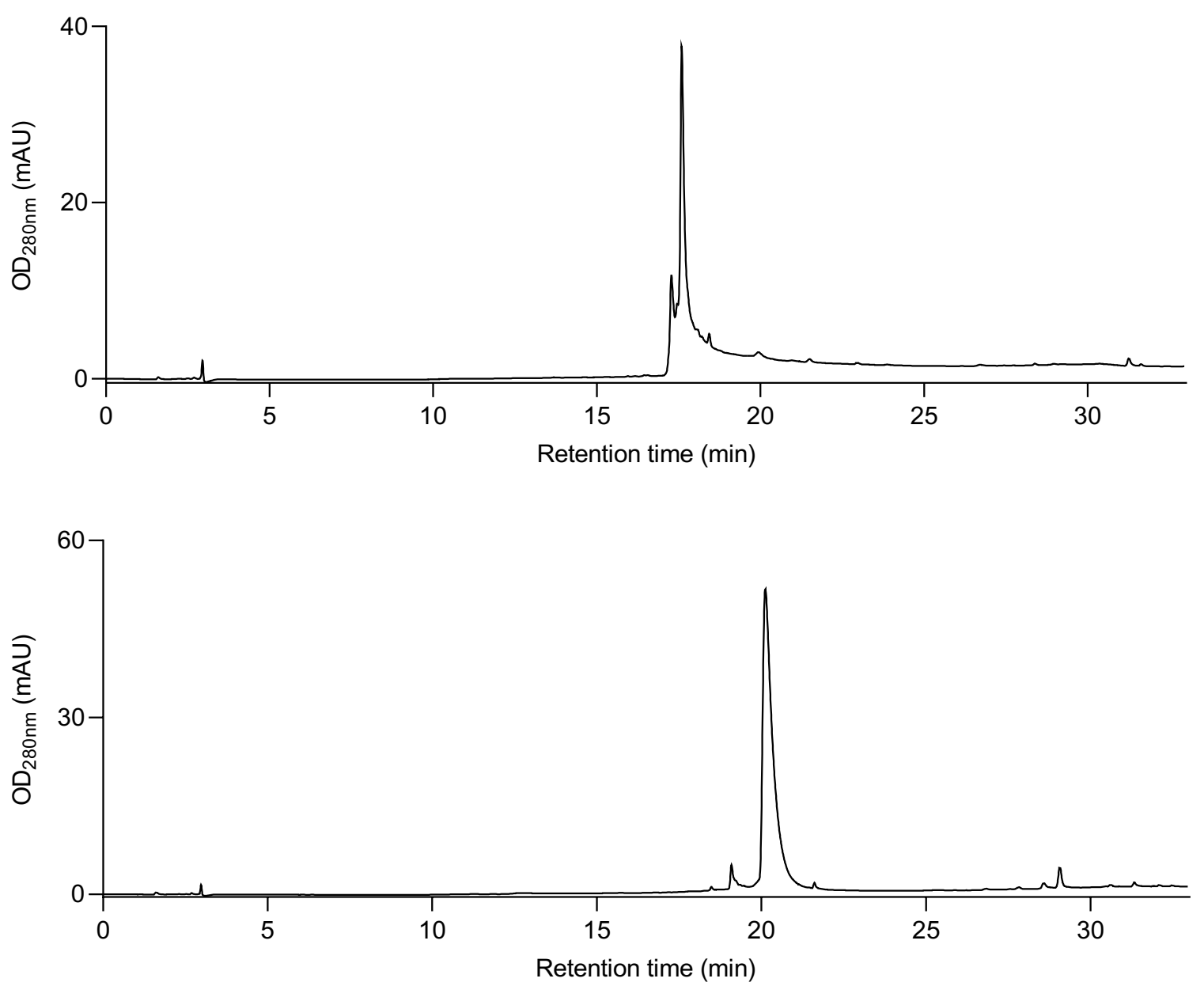

Figure S40. HPLC-MS analysis of pure $\mathbf{3 2}$ as a 7 mer hydrazide (top) and as a CoA thioester adduct (bottom). 

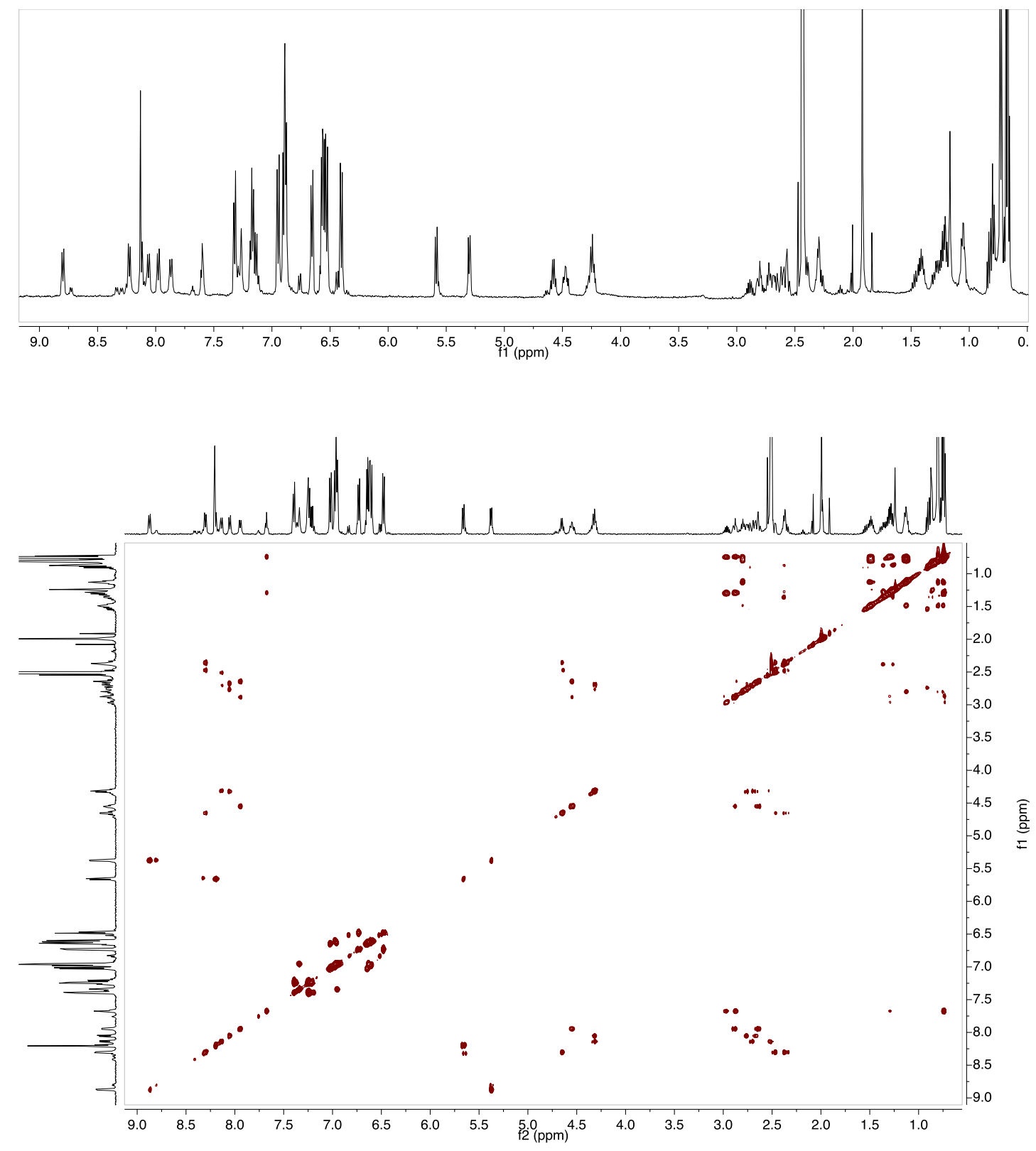

Figure S41. $800 \mathrm{MHz}{ }^{1} \mathrm{H}$ NMR of 25 in $\left(\mathrm{CD}_{3}\right)_{2} \mathrm{SO}$ (top). $800 \mathrm{MHz}$ COSY spectra of 25 in $\left(\mathrm{CD}_{3}\right)_{2} \mathrm{SO}$ (bottom). 

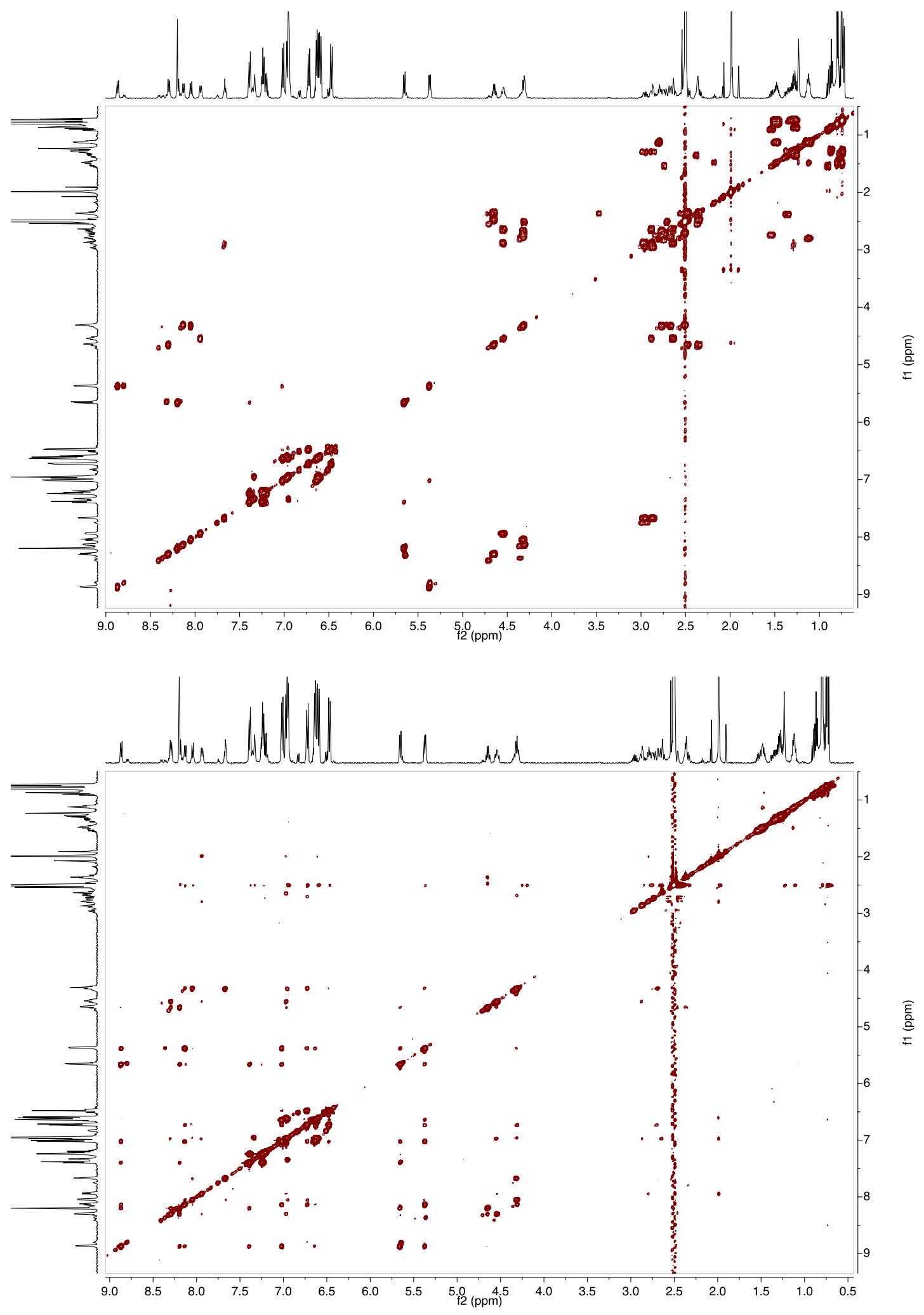

Figure S42. $800 \mathrm{MHz}$ TOCSY spectra of 25 in $\left(\mathrm{CD}_{3}\right)_{2} \mathrm{SO}$ (top). $800 \mathrm{MHz}$ NOESY spectra of 25 in $\left(\mathrm{CD}_{3}\right)_{2} \mathrm{SO}$ (bottom). 

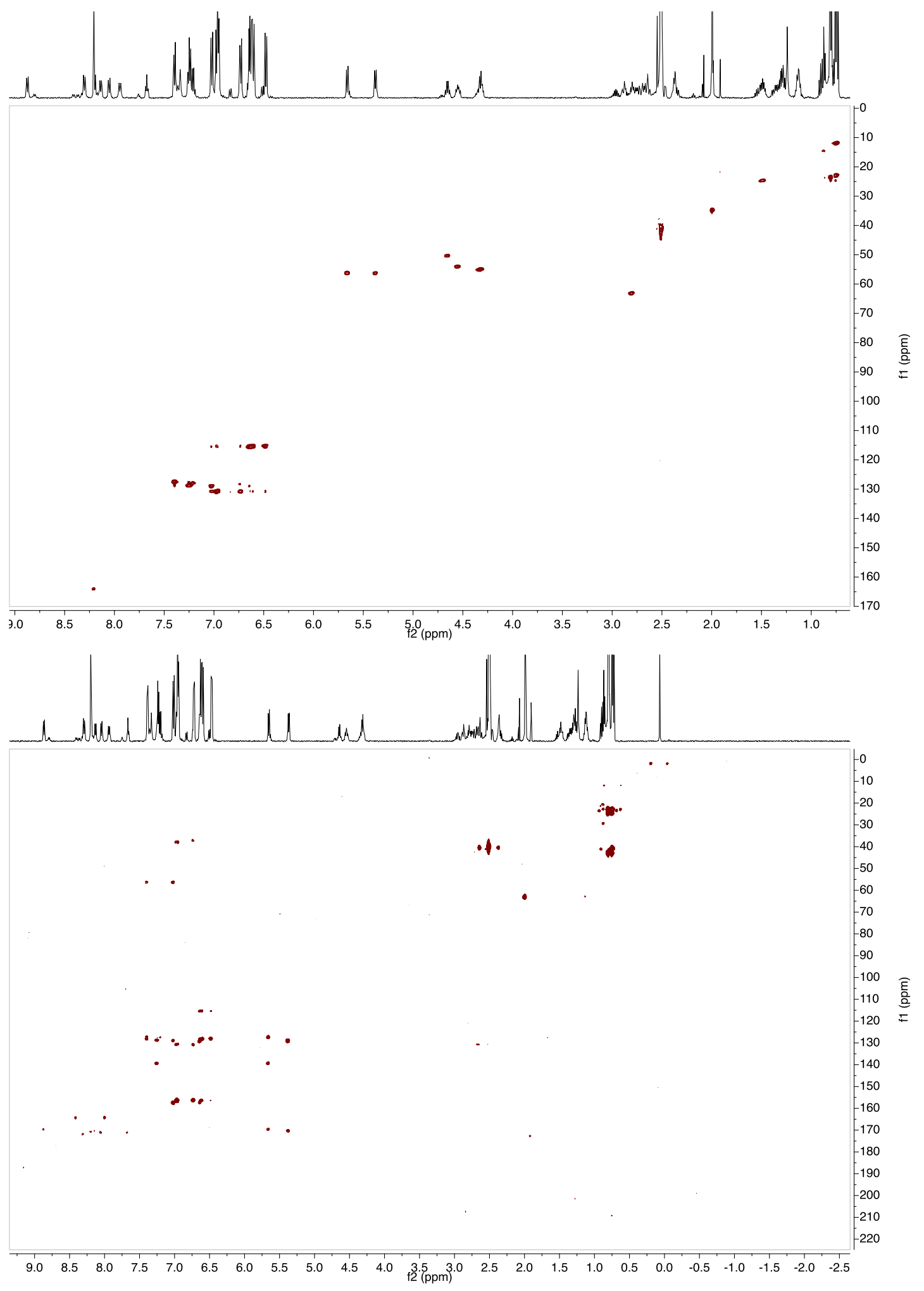

Figure S43. $800 \mathrm{MHz}$ HSQC spectra of 25 in $\left(\mathrm{CD}_{3}\right)_{2} \mathrm{SO}$ (top). $800 \mathrm{MHz} \mathrm{HMBC}$ spectra of 25 in $\left(\mathrm{CD}_{3}\right)_{2} \mathrm{SO}$ (bottom). 

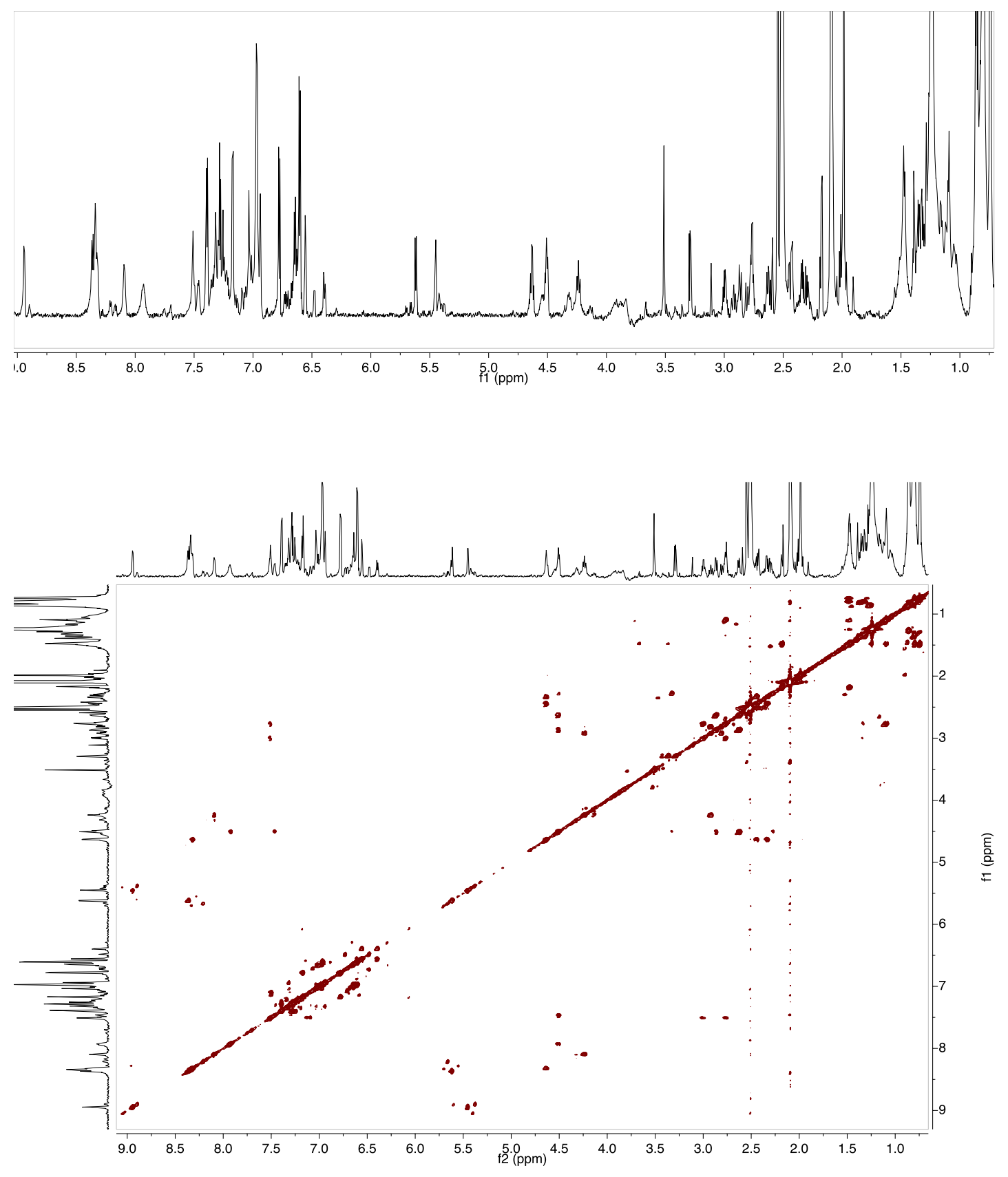

Figure S44. $800 \mathrm{MHz}{ }^{1} \mathrm{H}$ NMR of 26 in $\left(\mathrm{CD}_{3}\right)_{2} \mathrm{SO}$ (top). $800 \mathrm{MHz}$ COSY spectra of 26 in $\left(\mathrm{CD}_{3}\right)_{2} \mathrm{SO}$ (bottom). 

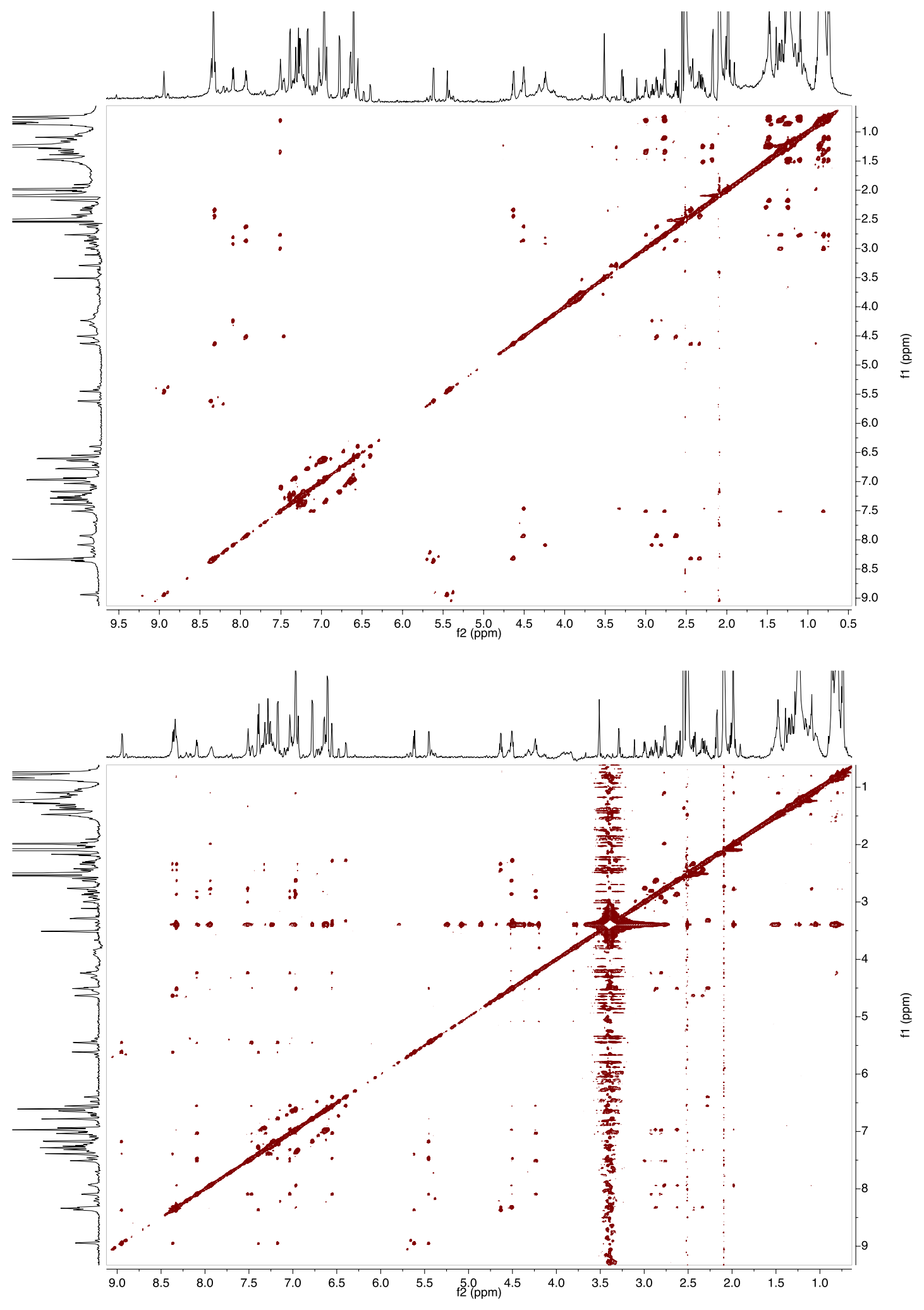

Figure S45. $800 \mathrm{MHz}$ TOCSY of 26 in $\left(\mathrm{CD}_{3}\right)_{2} \mathrm{SO}$ (top). $800 \mathrm{MHz}$ NOESY spectra of 26 in $\left(\mathrm{CD}_{3}\right)_{2} \mathrm{SO}$ (bottom). 


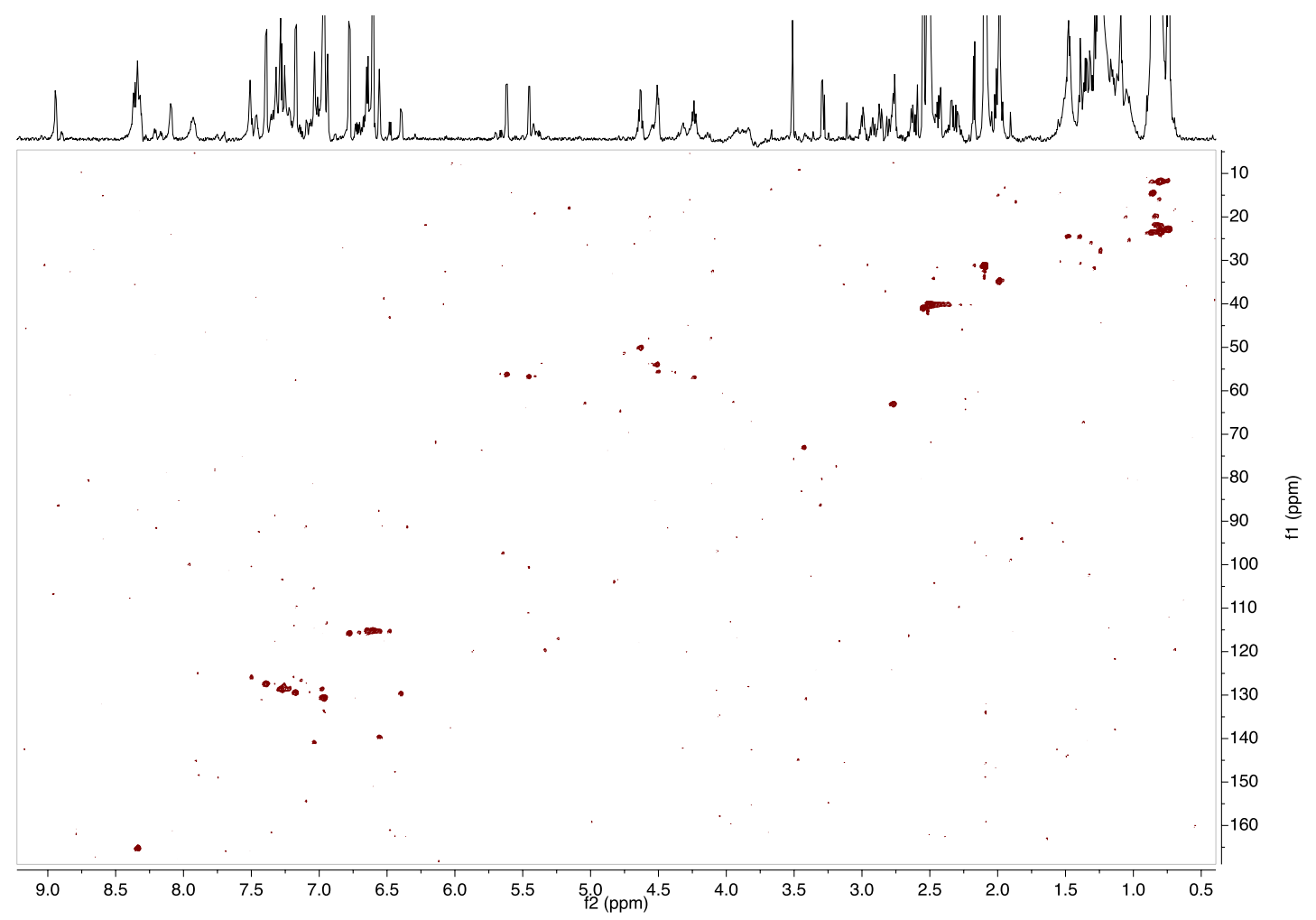

Figure S46. $800 \mathrm{MHz} \mathrm{HSQC}$ of 26 in $\left(\mathrm{CD}_{3}\right)_{2} \mathrm{SO}$ (top). 
A

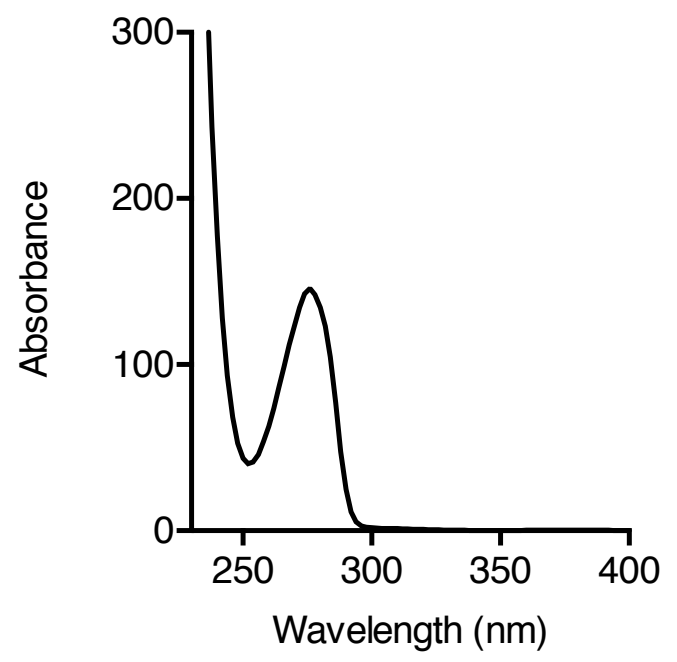

B

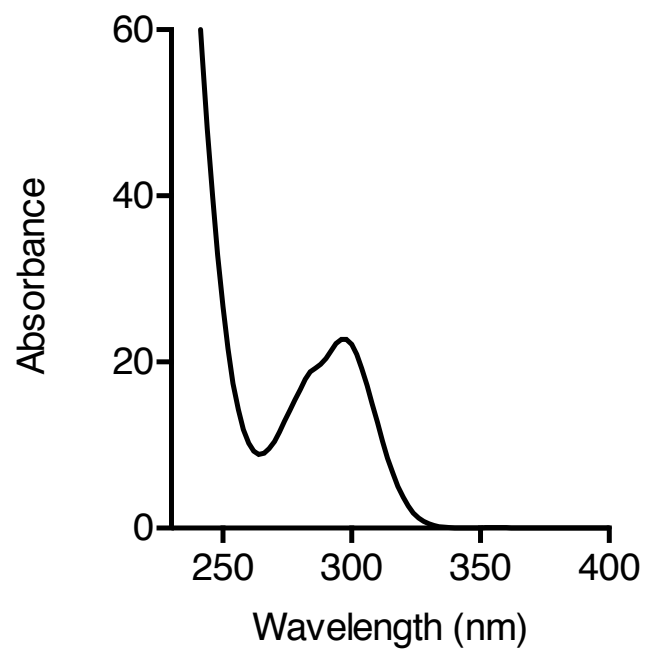

Figure S47. UV-Vis spectra of A) substrate 25; B) product 26. 

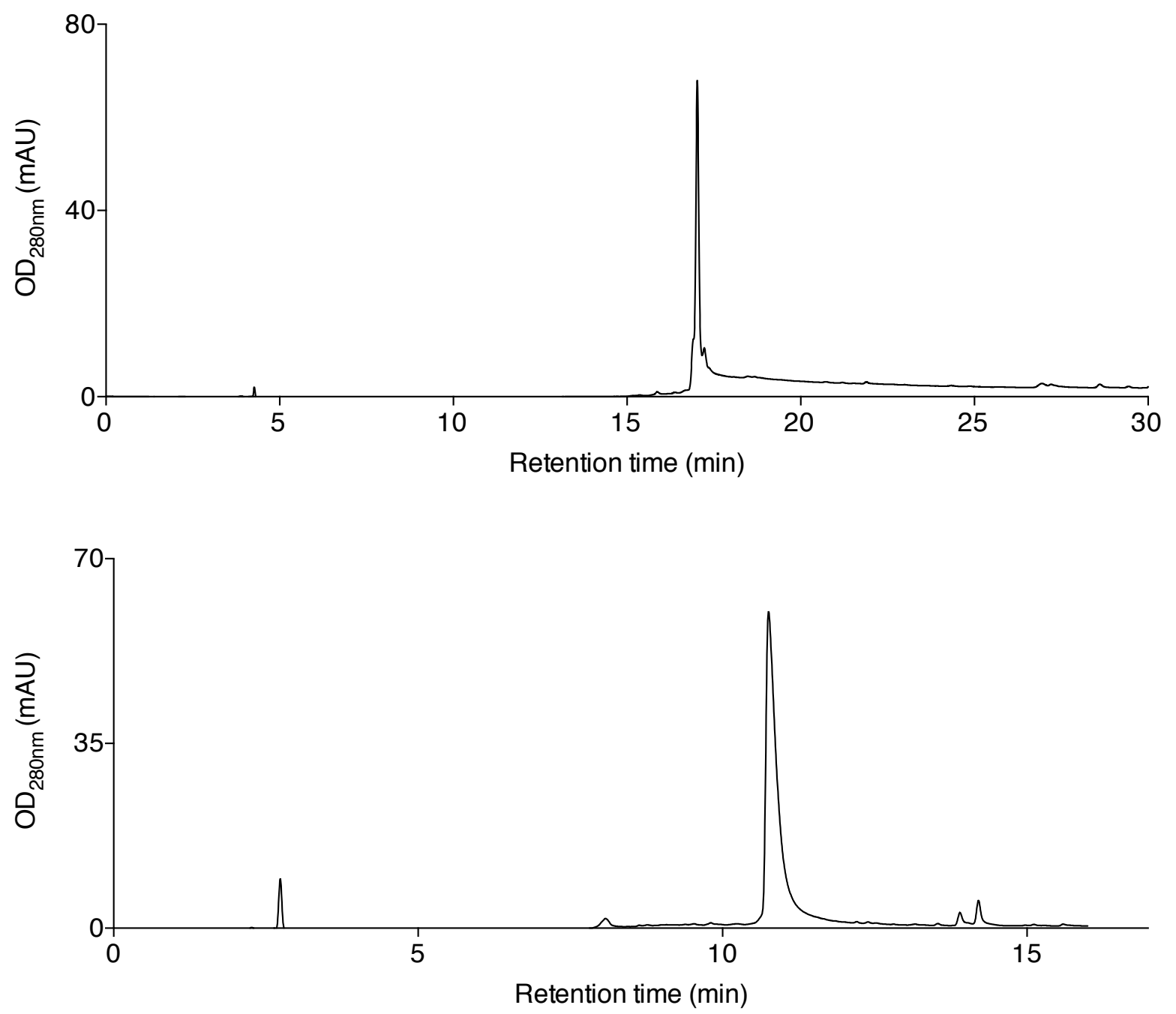

Figure S48. HPLC-MS analysis of pure peptide containing ortho- ${ }^{2} \mathrm{H}_{2}-\mathrm{L}-\mathrm{Tyr} 1, \mathrm{~L}-\mathrm{Phe} 2$, D-Hpg3, D-Hpg4 as a 7 mer hydrazide (top) and as a CoA thioester adduct (bottom). 

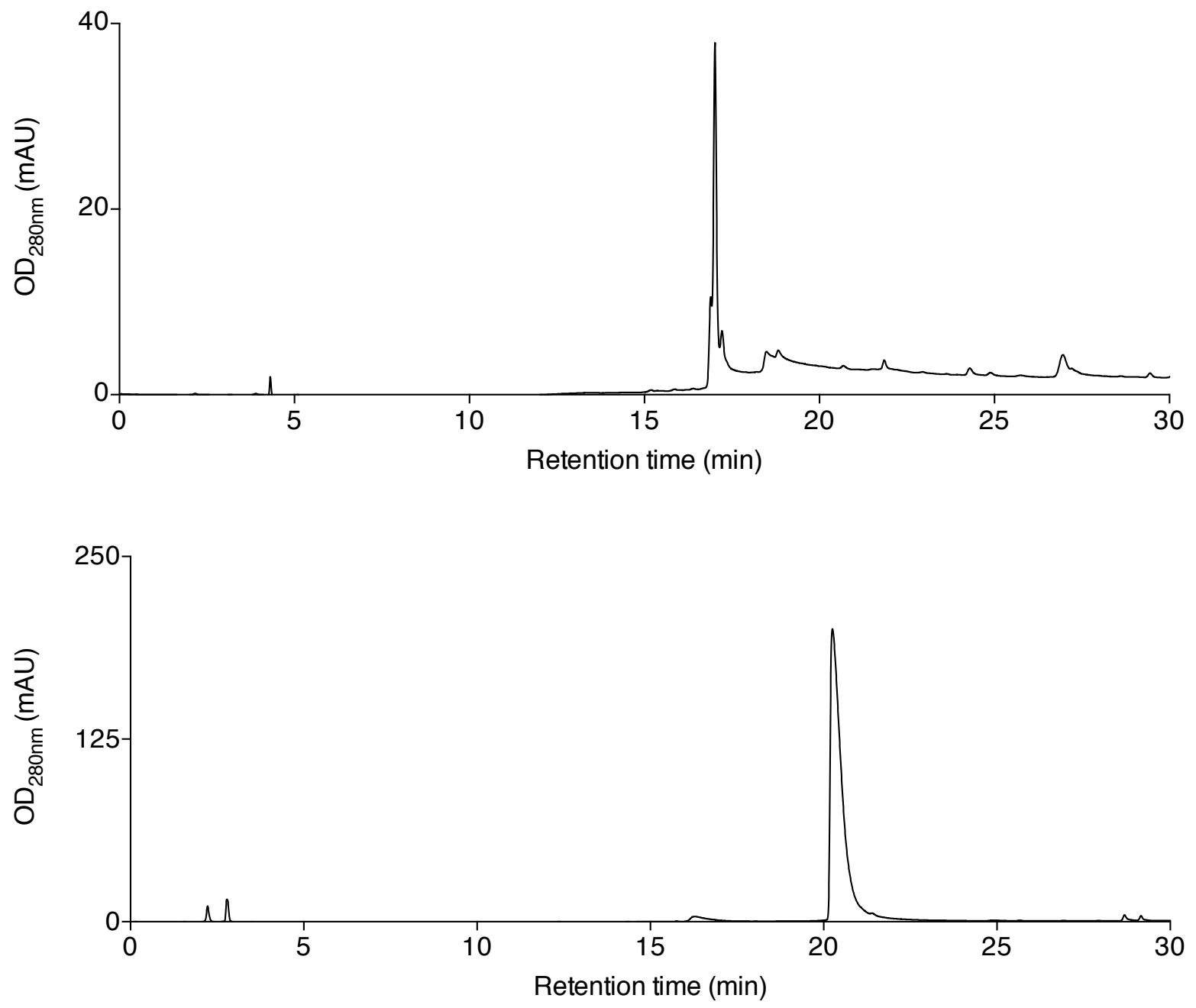

Figure S49. HPLC-MS analysis of pure peptide containing L-Tyr1, ring- ${ }^{2} \mathrm{H}_{5}-\mathrm{L}-\mathrm{Phe} 2$, D-Hpg3, D-Hpg4 as a 7mer hydrazide (top) and as a CoA thioester adduct (bottom). 

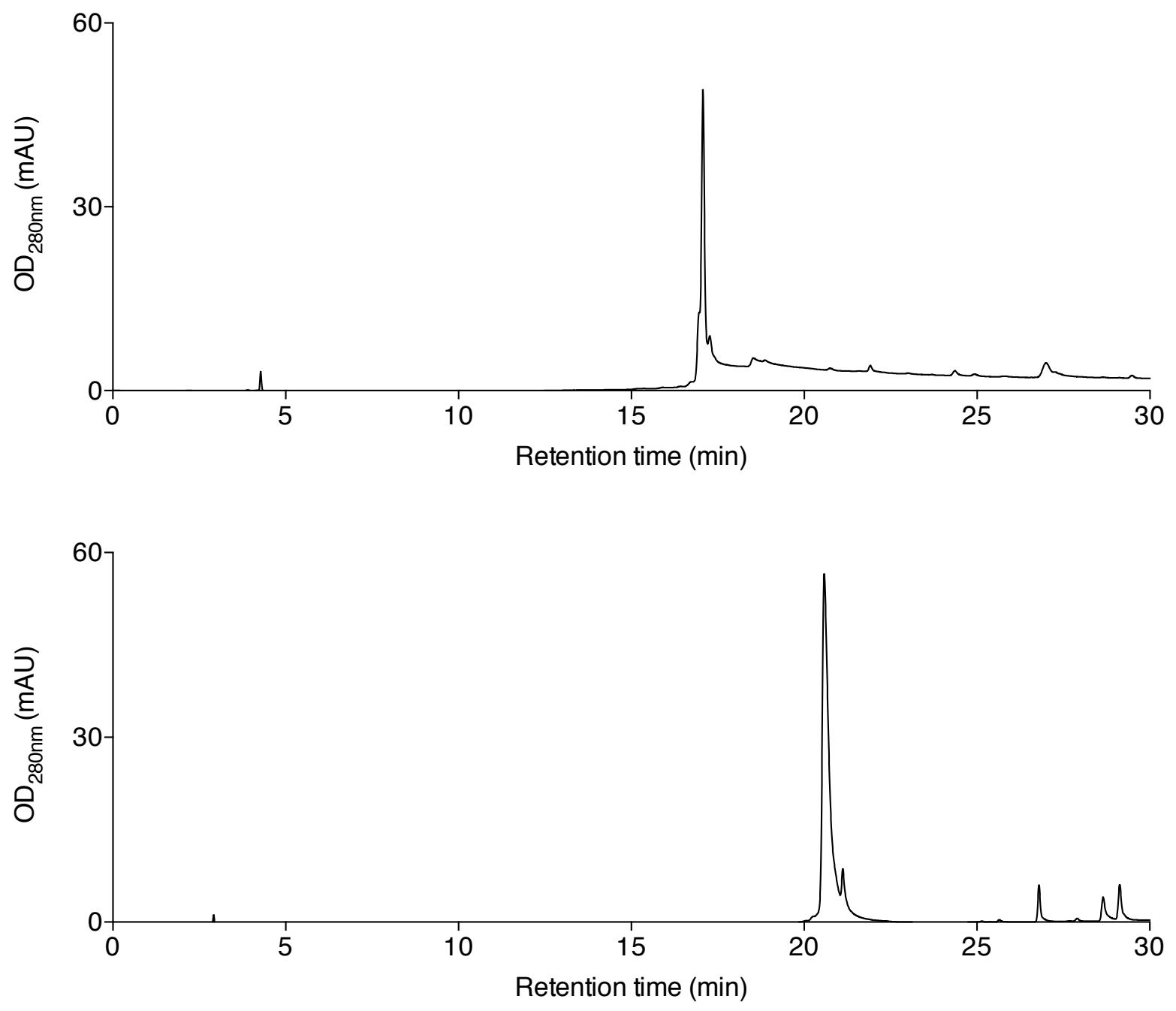

Figure S50. HPLC-MS analysis of pure peptide containing L-Tyr1, L-Phe2, ortho- ${ }^{2} \mathrm{H}_{2}-\mathrm{D}-\mathrm{Hpg} 3$, D-Hpg4 as a 7mer hydrazide (top) and as a CoA thioester adduct (bottom). 

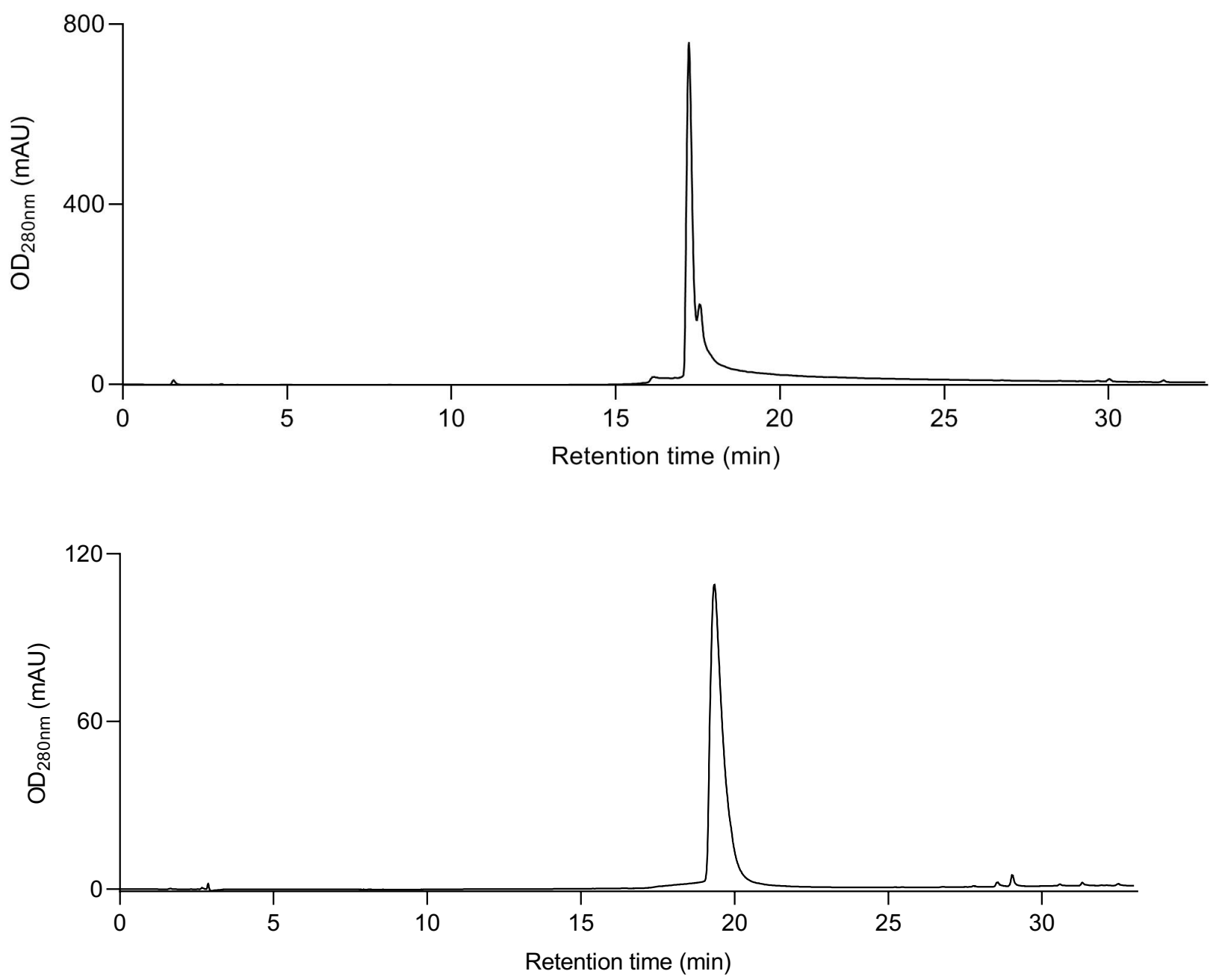

Figure S51. HPLC-MS analysis of pure peptide containing L-Tyr1, L-Phe2, D-Hpg3, ortho- ${ }^{2} \mathrm{H}_{2}-$ D-Hpg4 as a 7mer hydrazide (top) and as a CoA thioester adduct (bottom). 

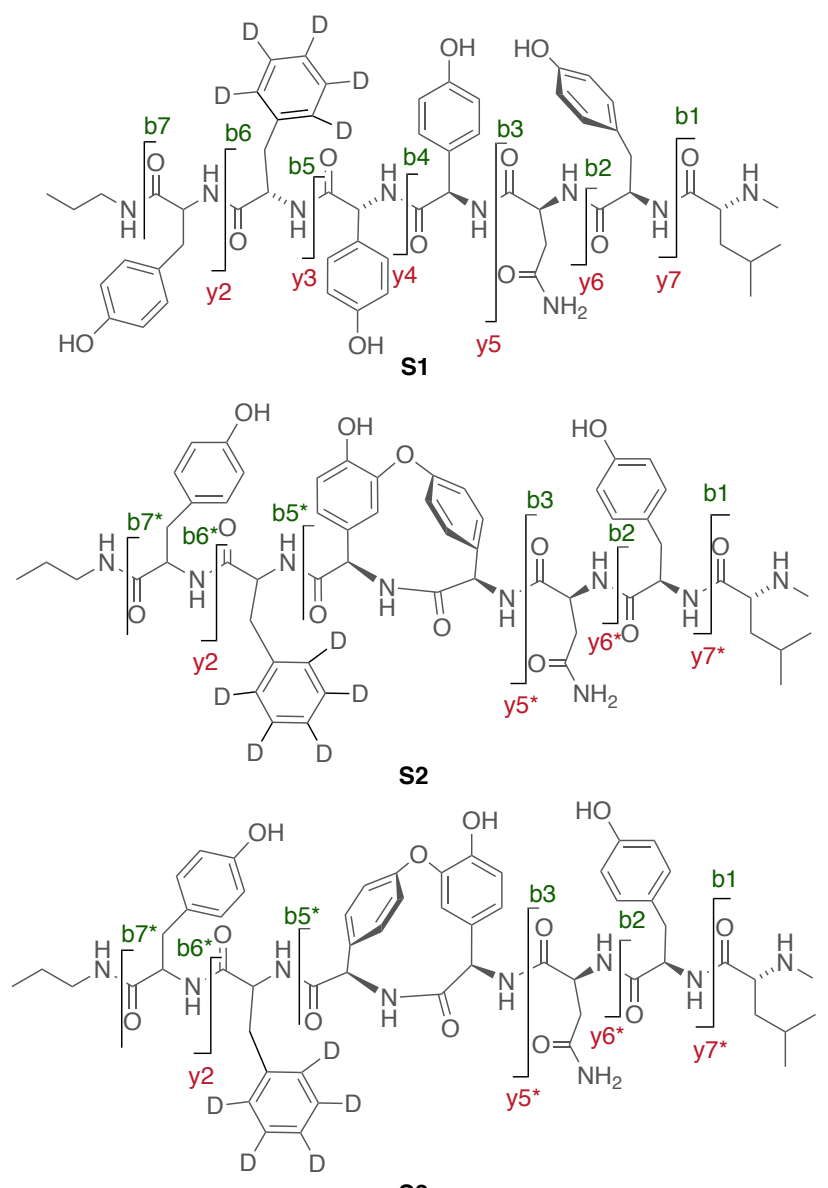

S3
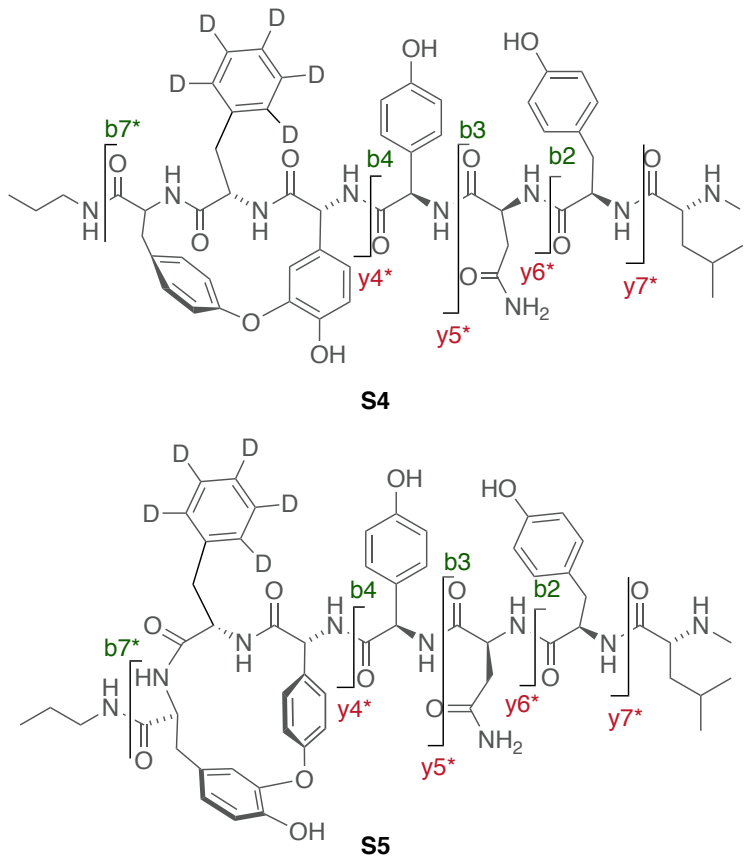

Figure S52. HR-MS/MS for substrate S1, with isotopically labelled AA2 $\left({ }^{2} \mathrm{H}_{5}-\mathrm{L}-\mathrm{Phe}\right)$, and products obtained upon reaction with OxyB (-2 Da products: S2, S3, S4, S5). 

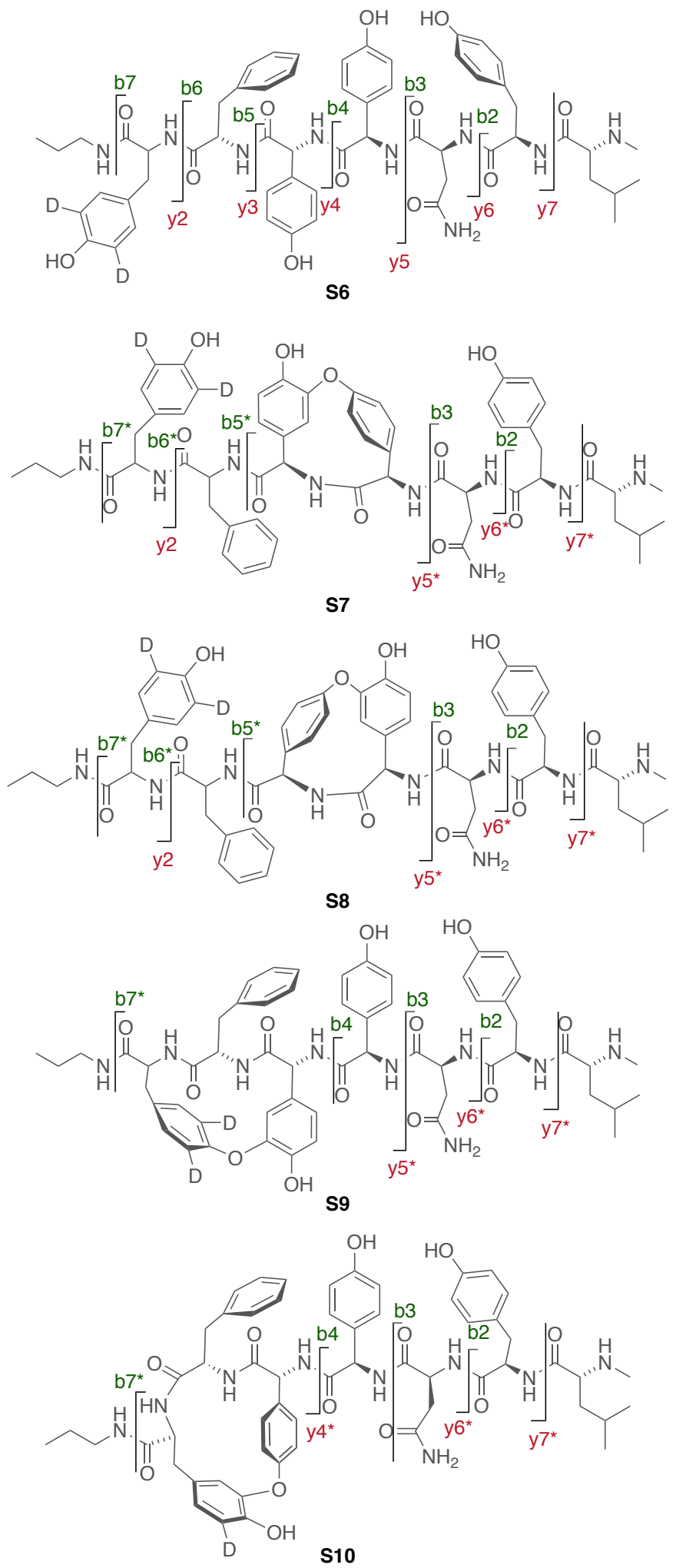

Figure S53. HR-MS/MS for substrate S6, with isotopically labelled AA1 $\left(3,5-{ }^{2} \mathrm{H}_{2}-\mathrm{L}-\mathrm{Tyr}\right)$, and products obtained upon reaction with OxyB (-2 Da products, S7, S8, S9; -3Da product, S10). 

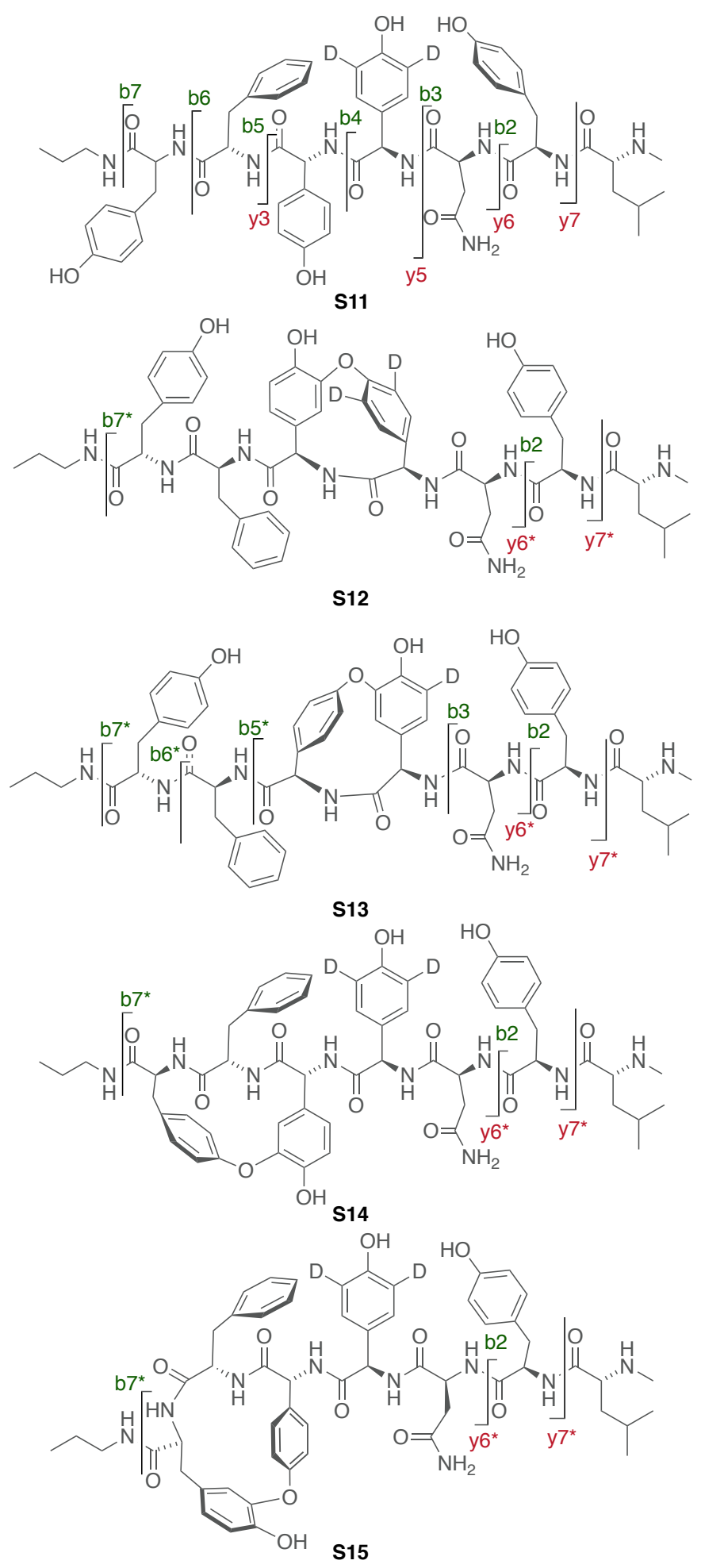

Figure S54. HR-MS/MS for substrate S11, with isotopically labelled AA4 (3,5- $\left.{ }^{2} \mathrm{H}_{2}-\mathrm{D}-\mathrm{Hpg} 4\right)$, and products obtained upon reaction with OxyB (-2 Da products, S12, S14, S15; -3Da product, S13). 

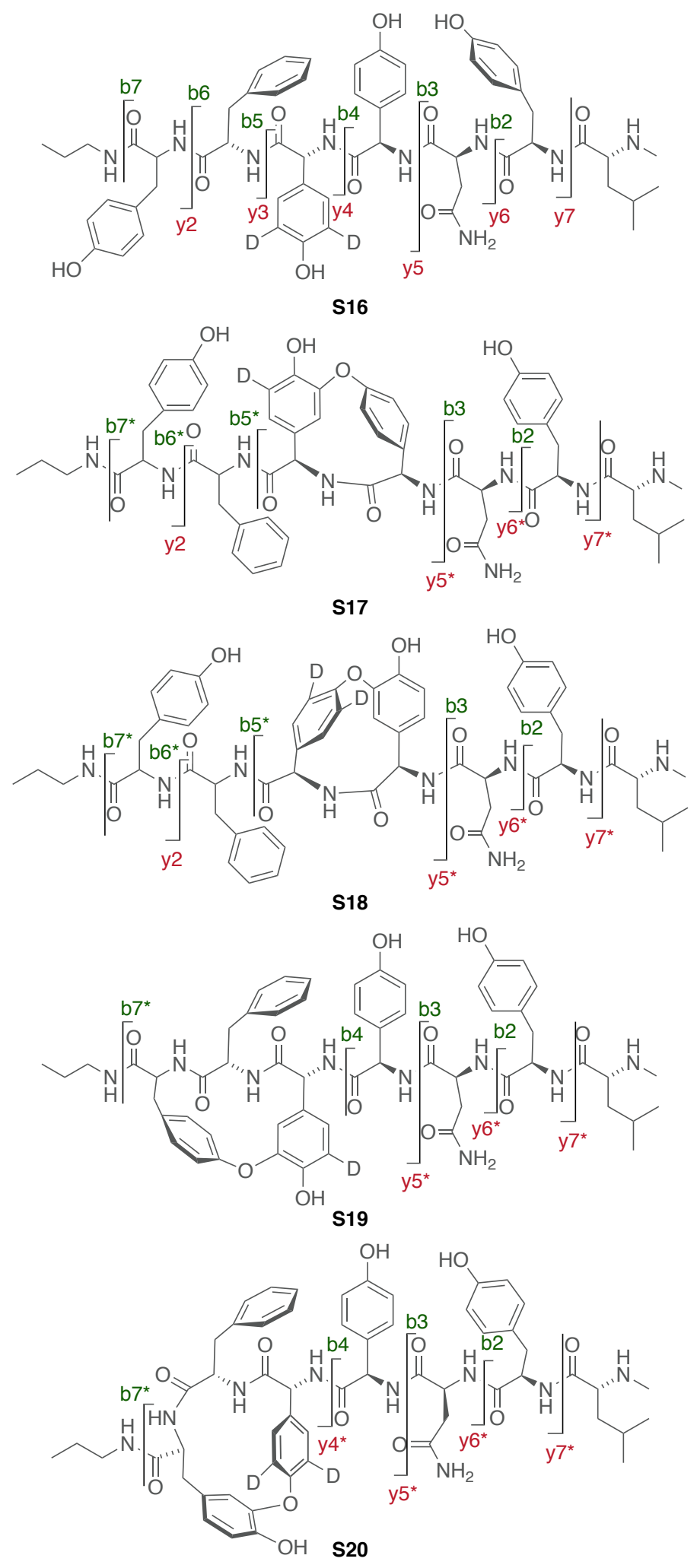

Figure S55. HR-MS/MS for substrate S16, with isotopically labelled AA3 (3,5- $\left.{ }^{2} \mathrm{H}_{2}-\mathrm{D}-\mathrm{Hpg}\right)$, and products obtained upon reaction with OxyB (-2 Da products, S18, S20; -3Da product, S17, S19). 

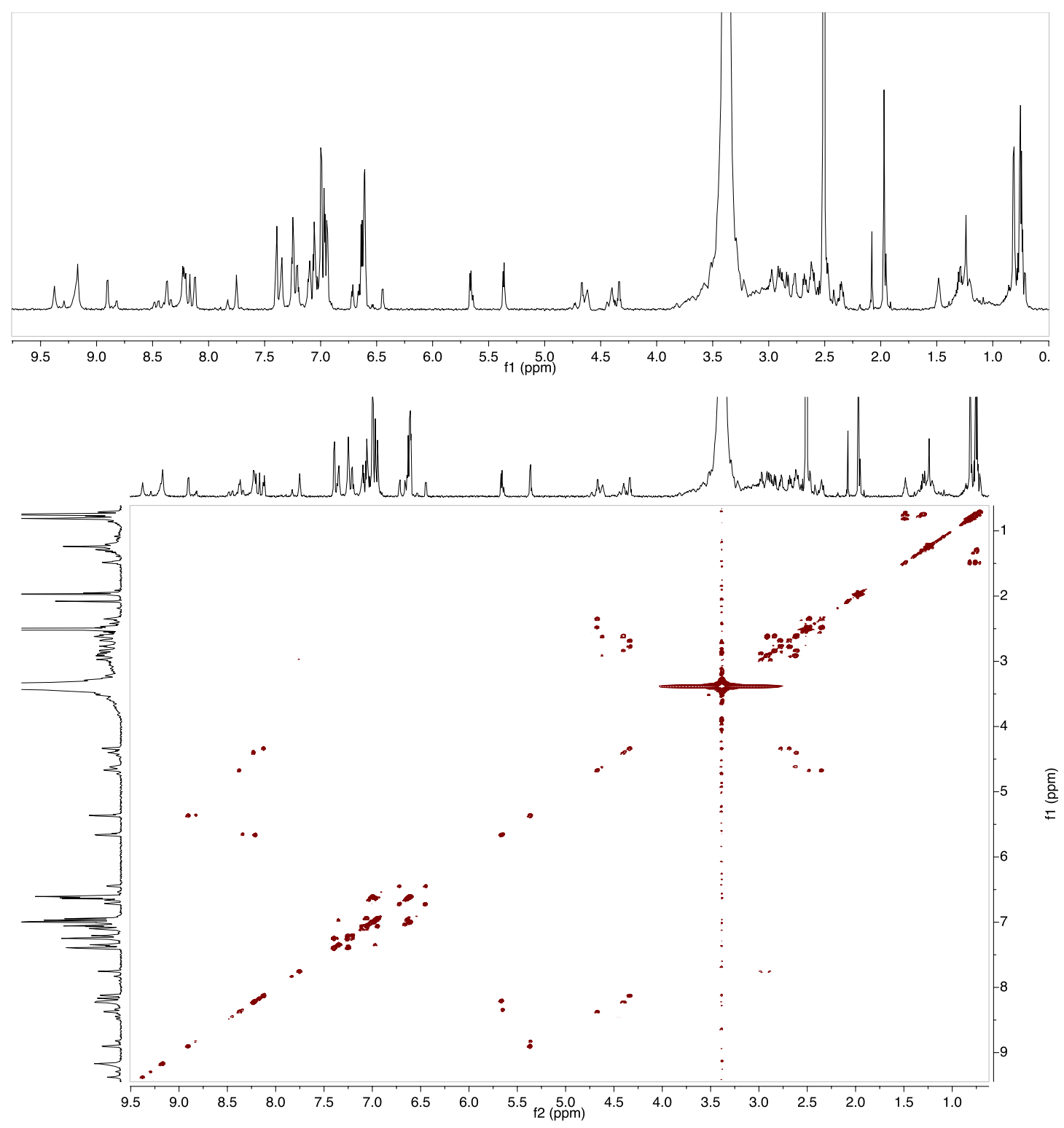

Figure S56. $800 \mathrm{MHz}{ }^{1} \mathrm{H}$ NMR of 32 in $\left(\mathrm{CD}_{3}\right)_{2} \mathrm{SO}$ (top). $800 \mathrm{MHz}$ COSY spectra of 32 in $\left(\mathrm{CD}_{3}\right)_{2} \mathrm{SO}$ (bottom). 


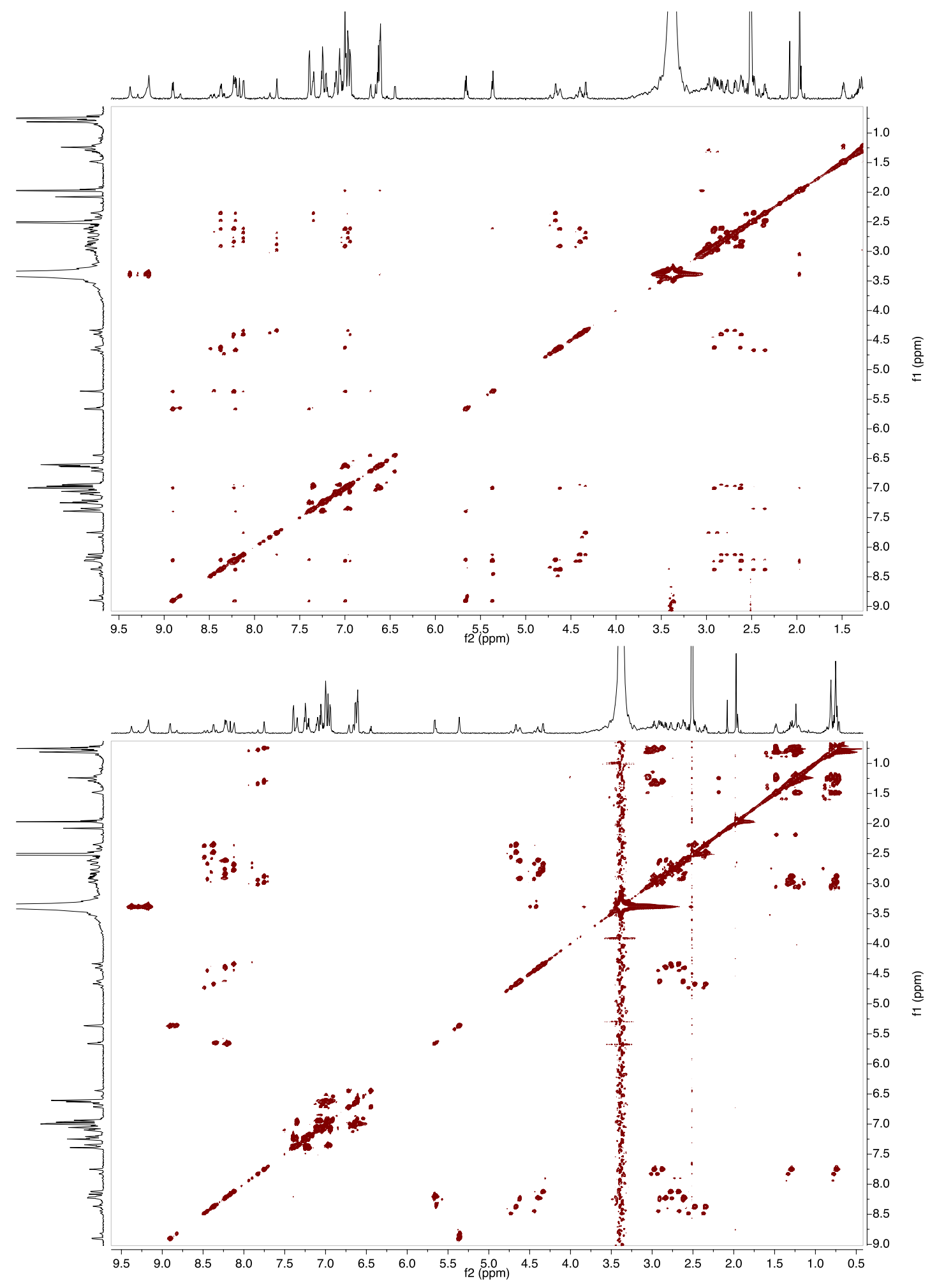

Figure S57. $800 \mathrm{MHz}$ TOCSY spectra of 32 in $\left(\mathrm{CD}_{3}\right)_{2} \mathrm{SO}$ (top). $800 \mathrm{MHz}$ NOESY spectra of $\mathbf{3 2}$ in $\left(\mathrm{CD}_{3}\right)_{2} \mathrm{SO}$ (bottom). 

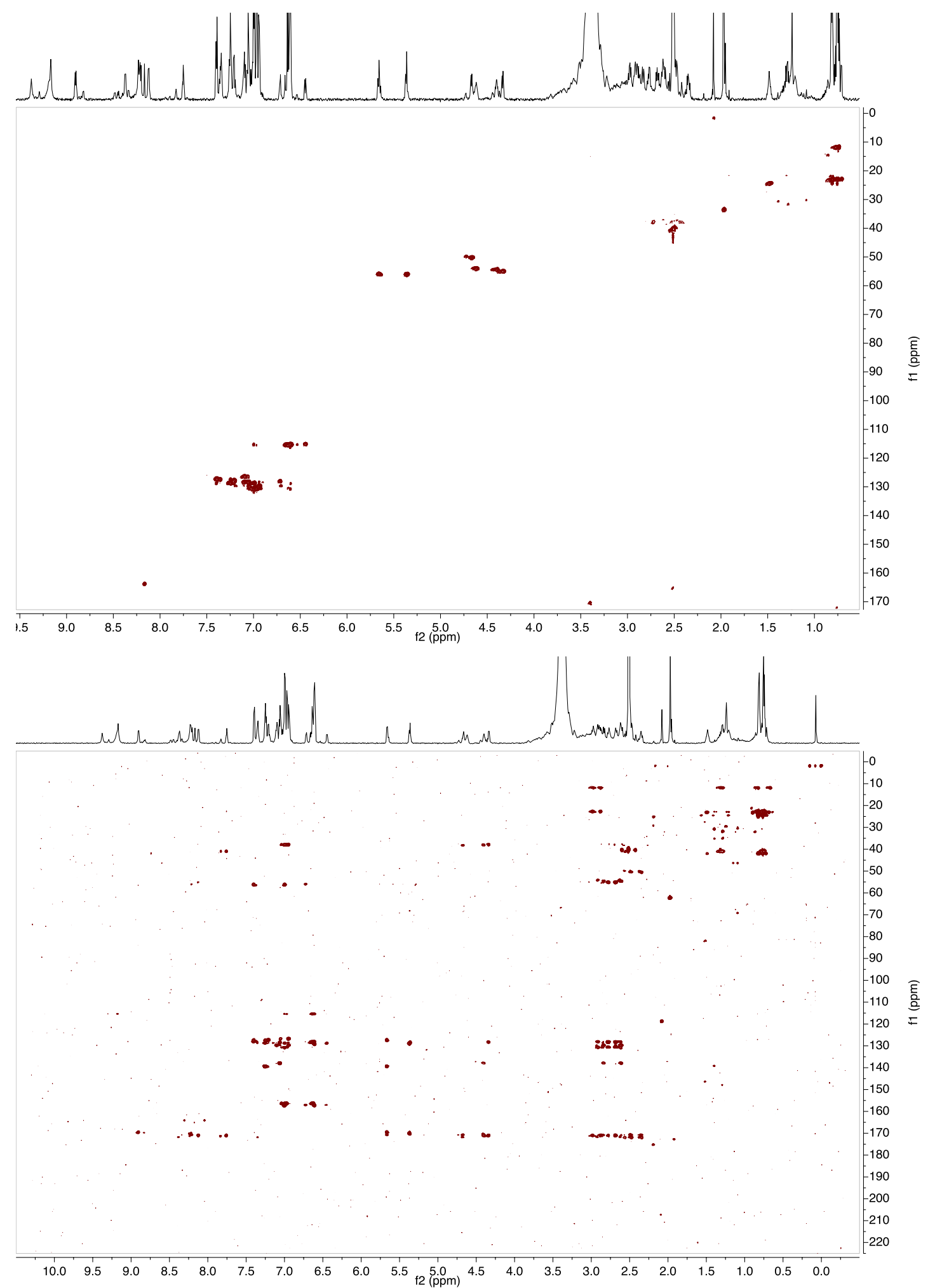

Figure S58. $800 \mathrm{MHz}$ HSQC spectra of $\mathbf{3 2}$ in $\left(\mathrm{CD}_{3}\right)_{2} \mathrm{SO}$ (top). $800 \mathrm{MHz} \mathrm{HMBC}$ spectra of $\mathbf{3 2}$ in $\left(\mathrm{CD}_{3}\right)_{2} \mathrm{SO}$ (bottom). 

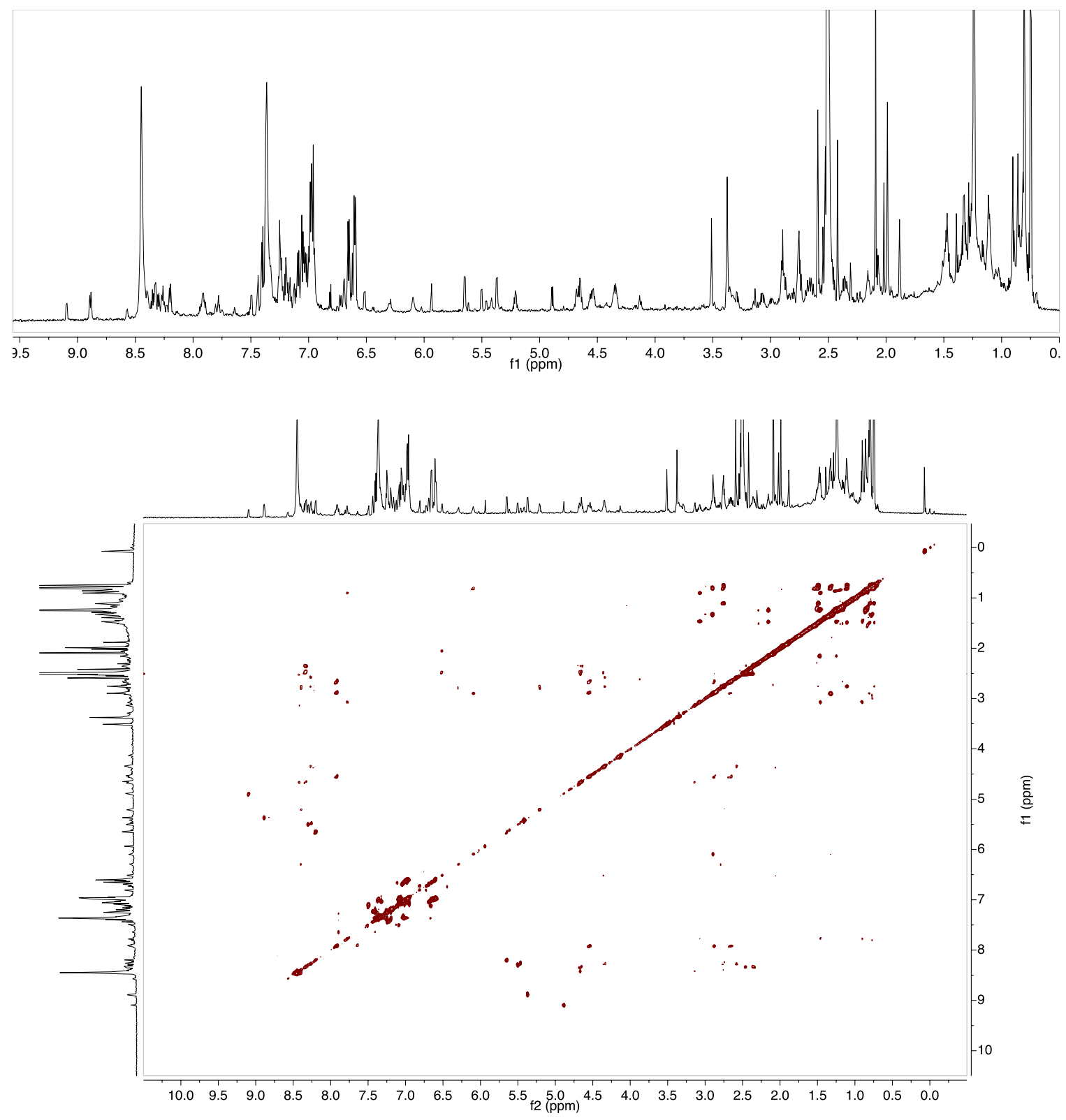

Figure S59. $800 \mathrm{MHz}{ }^{1} \mathrm{H}$ NMR of 33 in $\left(\mathrm{CD}_{3}\right)_{2} \mathrm{SO}$ (top). $800 \mathrm{MHz}$ COSY spectra of 33 in $\left(\mathrm{CD}_{3}\right)_{2} \mathrm{SO}$ (bottom). 

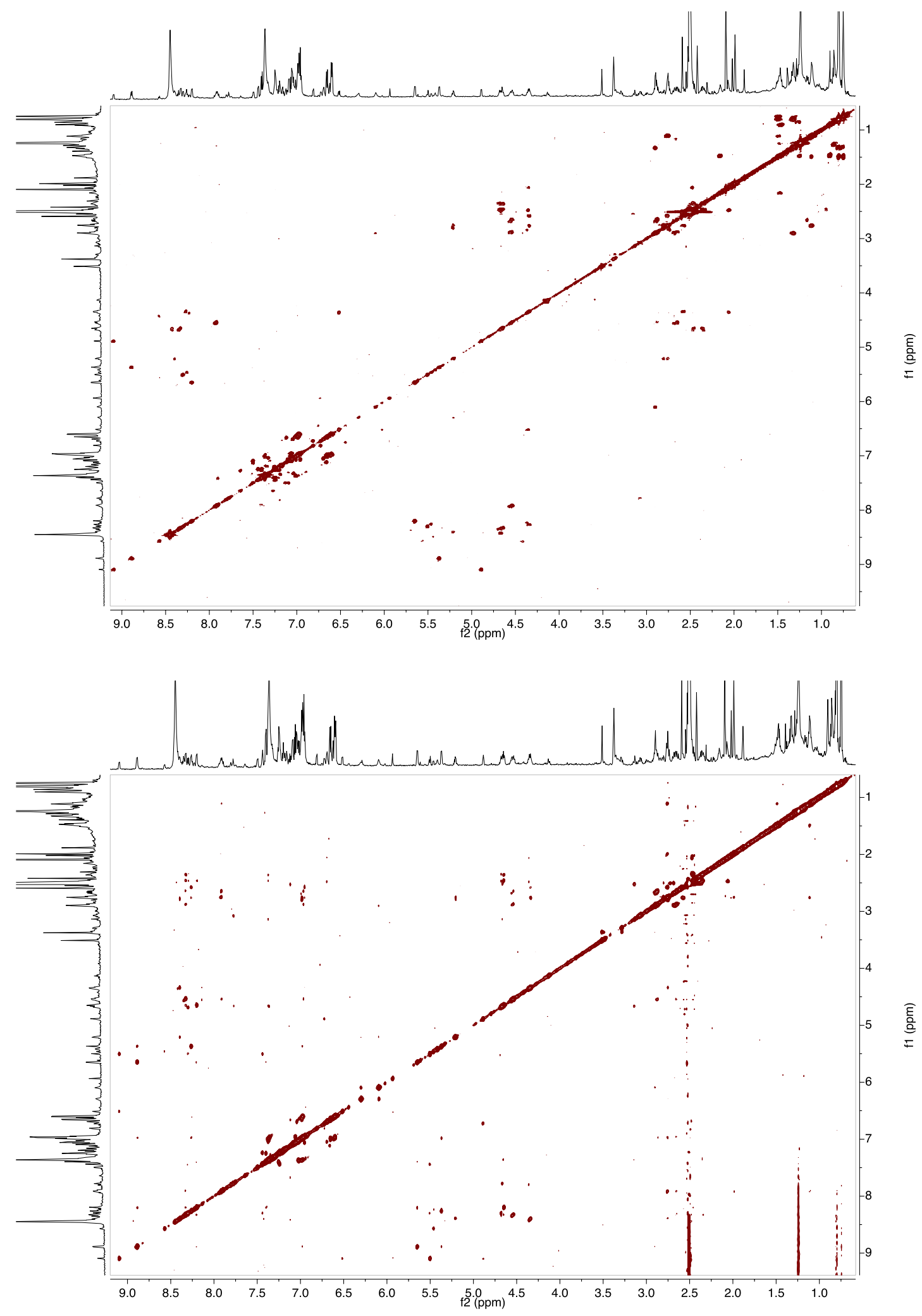

Figure S60. $800 \mathrm{MHz}$ TOCSY spectra of $\mathbf{3 3}$ in $\left(\mathrm{CD}_{3}\right)_{2} \mathrm{SO}$ (top). $800 \mathrm{MHz}$ NOESY spectra of $\mathbf{3 3}$ in $\left(\mathrm{CD}_{3}\right)_{2} \mathrm{SO}$ (bottom). 


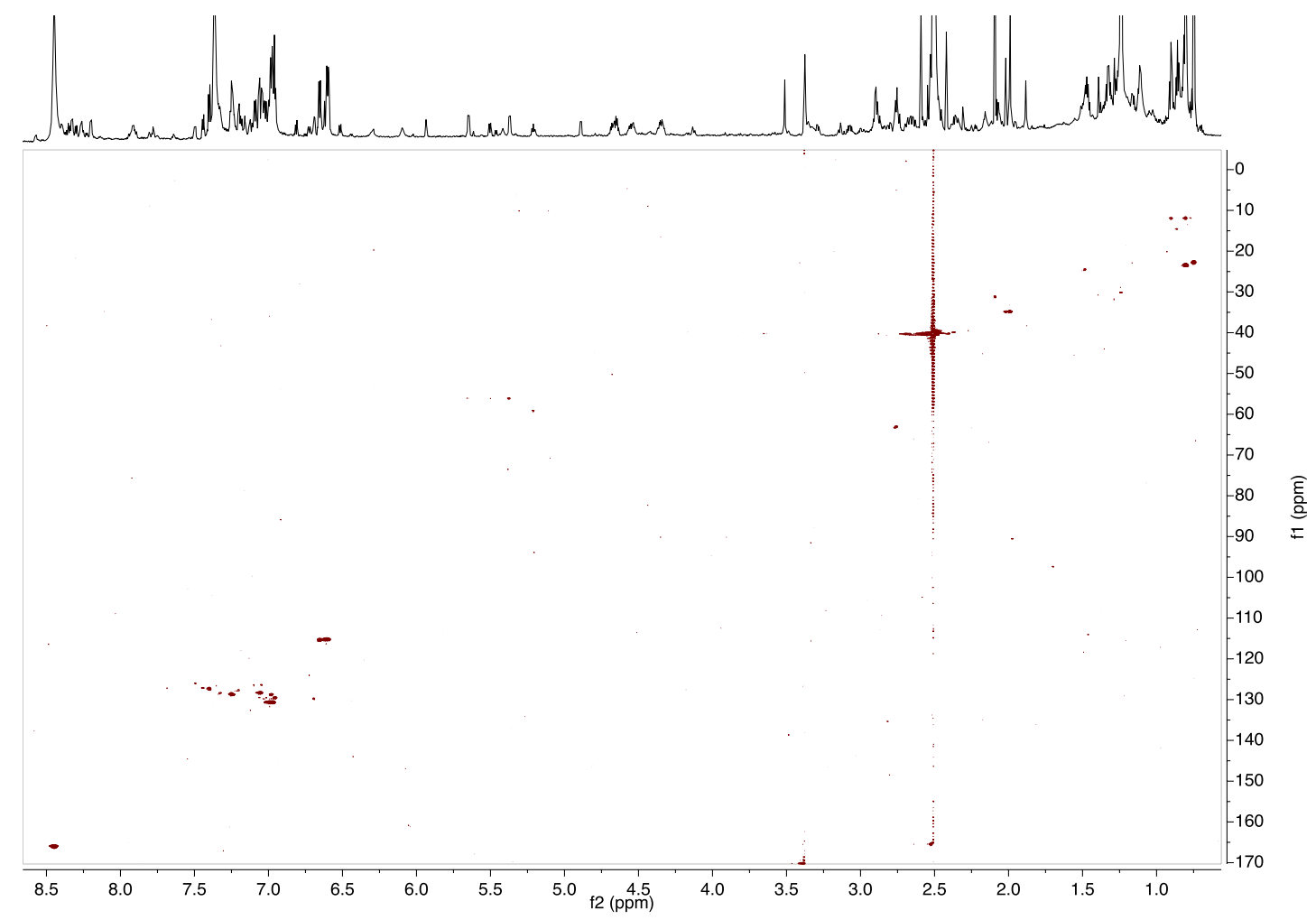

Figure S61. $800 \mathrm{MHz} \mathrm{HSQC}$ spectra of 33 in $\left(\mathrm{CD}_{3}\right)_{2} \mathrm{SO}$. 

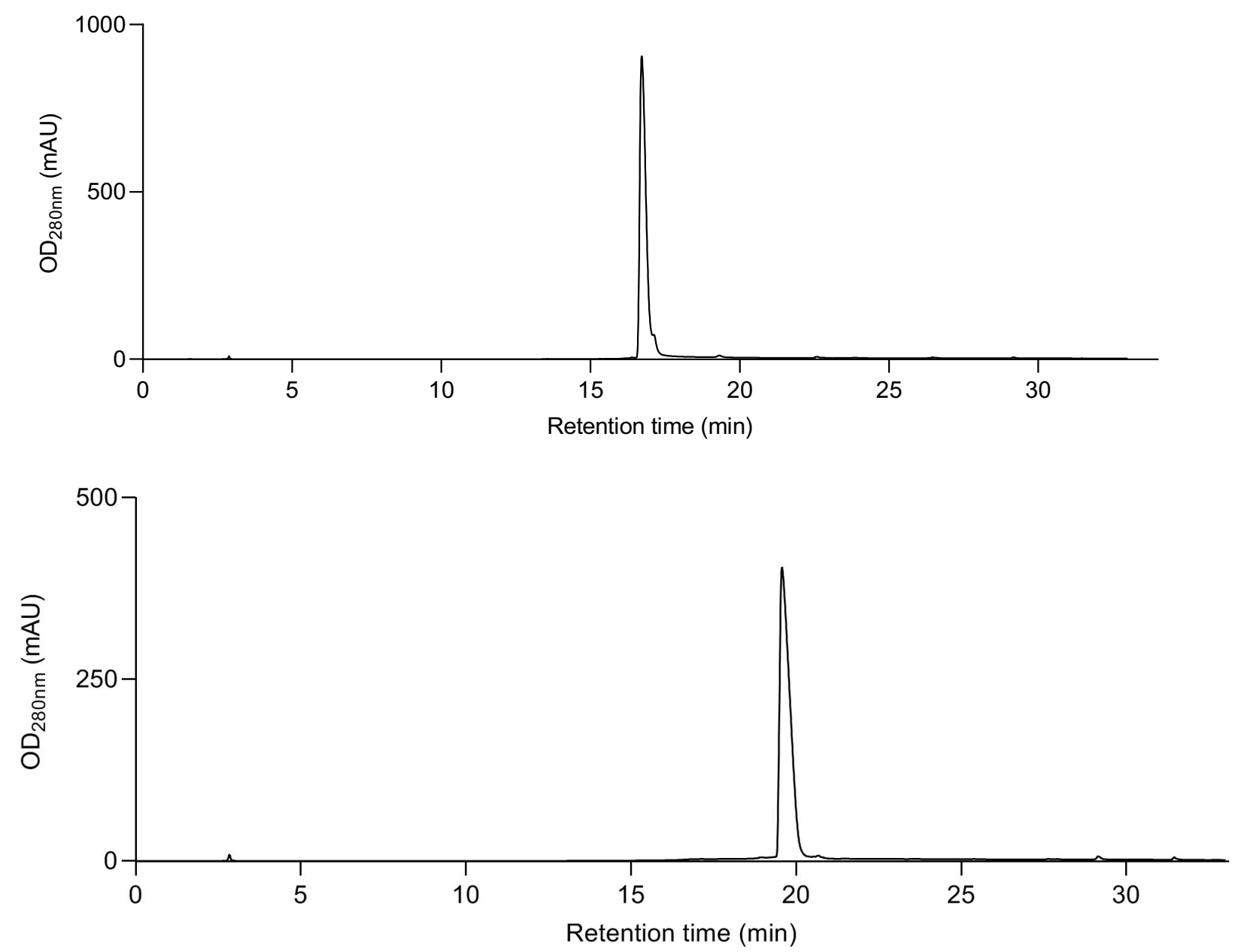

Figure S62. HPLC-MS analysis of pure 34 as a 7mer hydrazide (top) and as a CoA thioester adduct (bottom). 

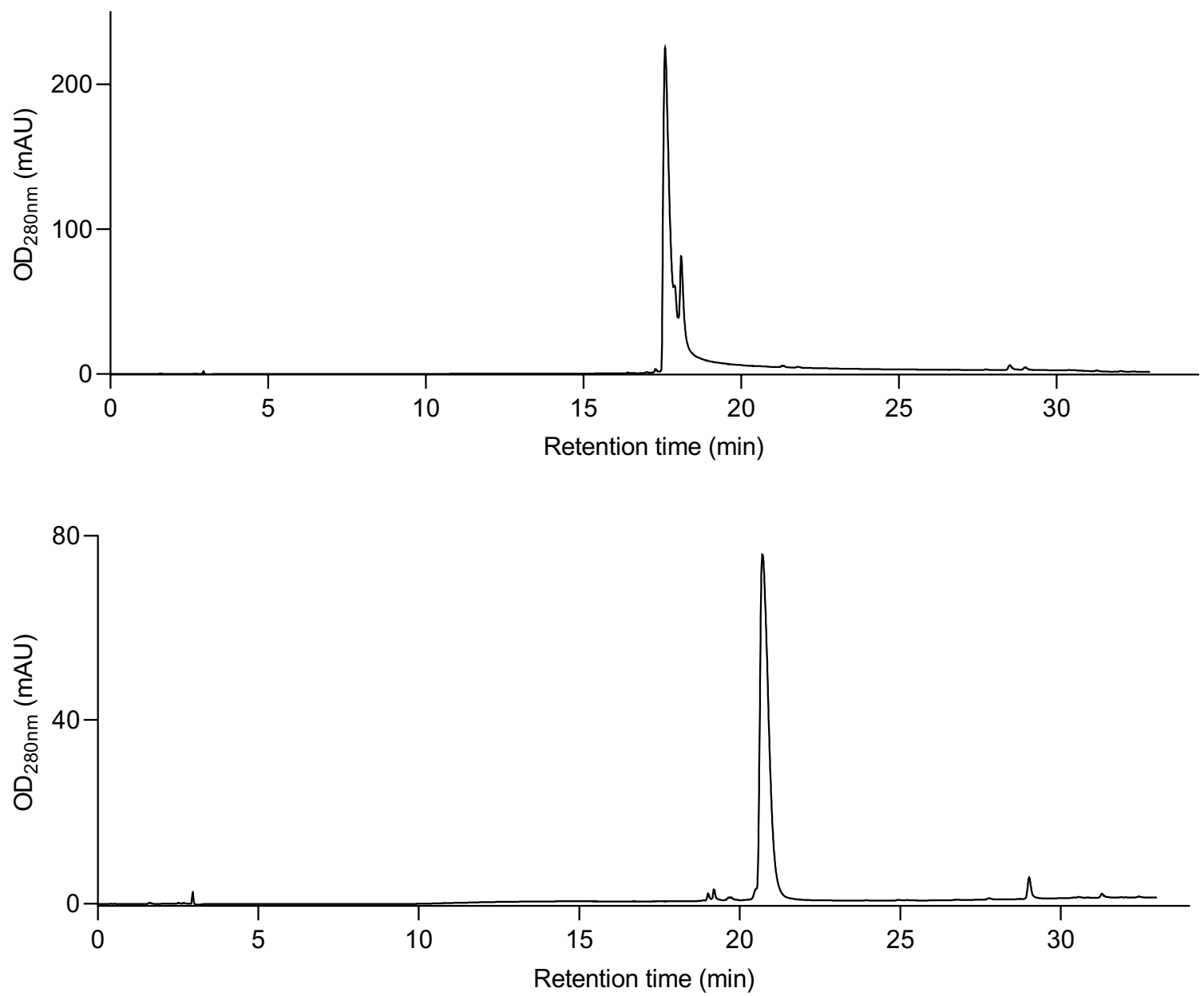

Figure S63. HPLC-MS analysis of pure 39 as a 7mer hydrazide (top) and as a CoA thioester adduct (bottom). 

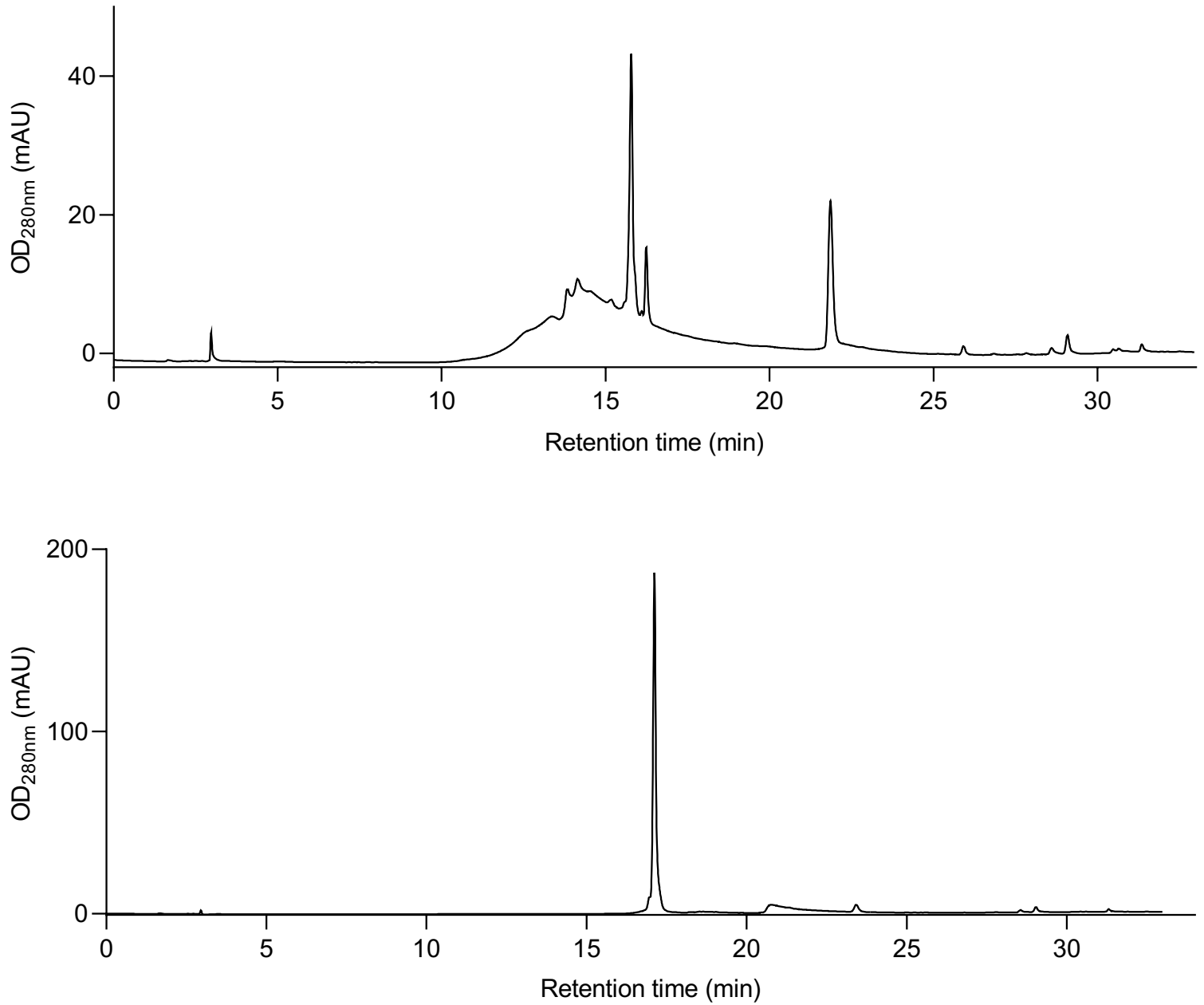

Figure S64. HPLC-MS analysis of pure $\mathbf{4 3}$ as a 7 mer CoA thioester adduct (top). HPLC-MS analysis of pure 46 as CoA thioester adduct (bottom). 

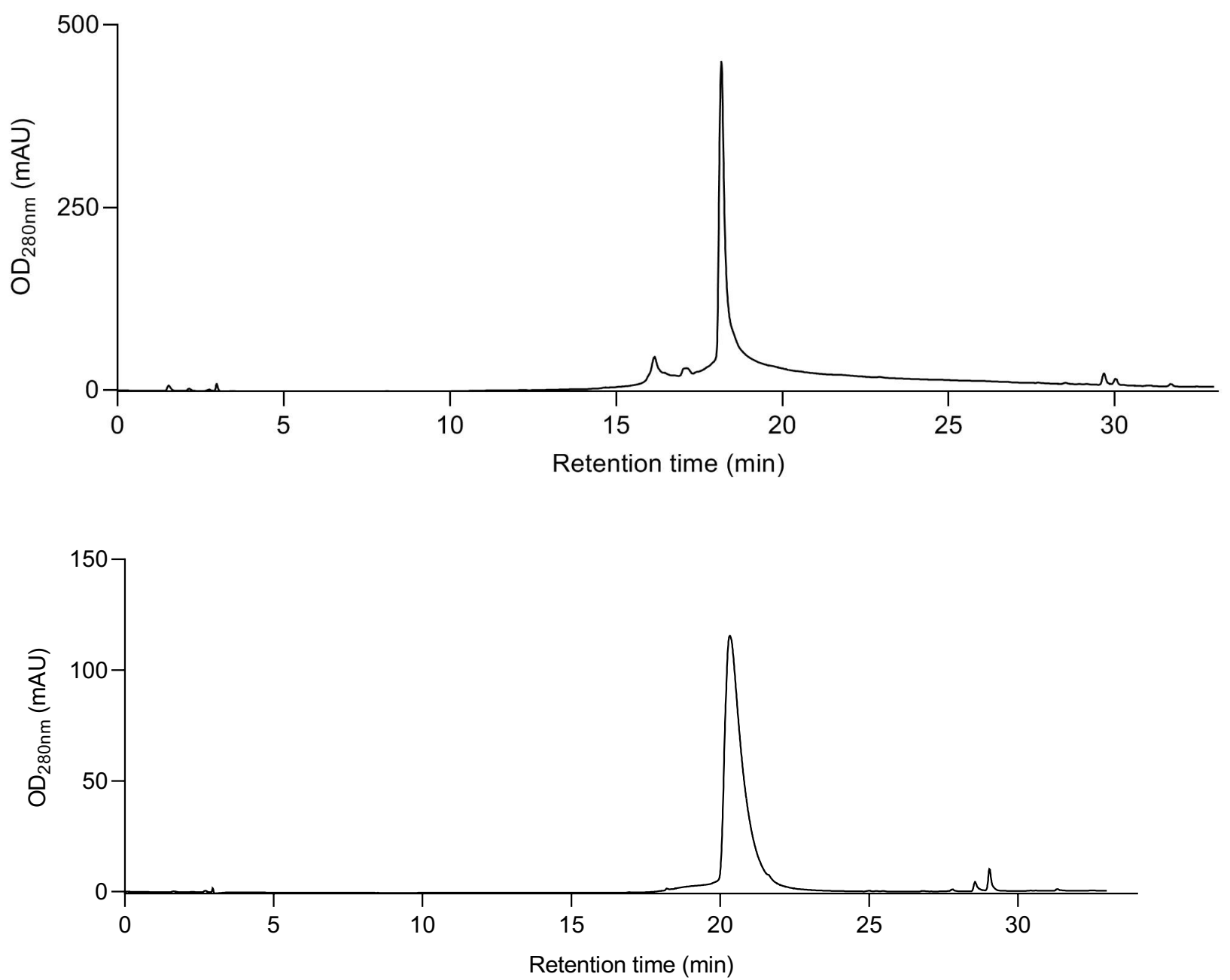

Figure S65. HPLC-MS analysis of pure peptide containing 4-Me-L-Phe2 and 3,5- ${ }^{2} \mathrm{H}_{2}-\mathrm{D}-\mathrm{Hpg} 4$ (precursor to 36) as a 7 mer hydrazide (top) and as a CoA thioester adduct (bottom). 

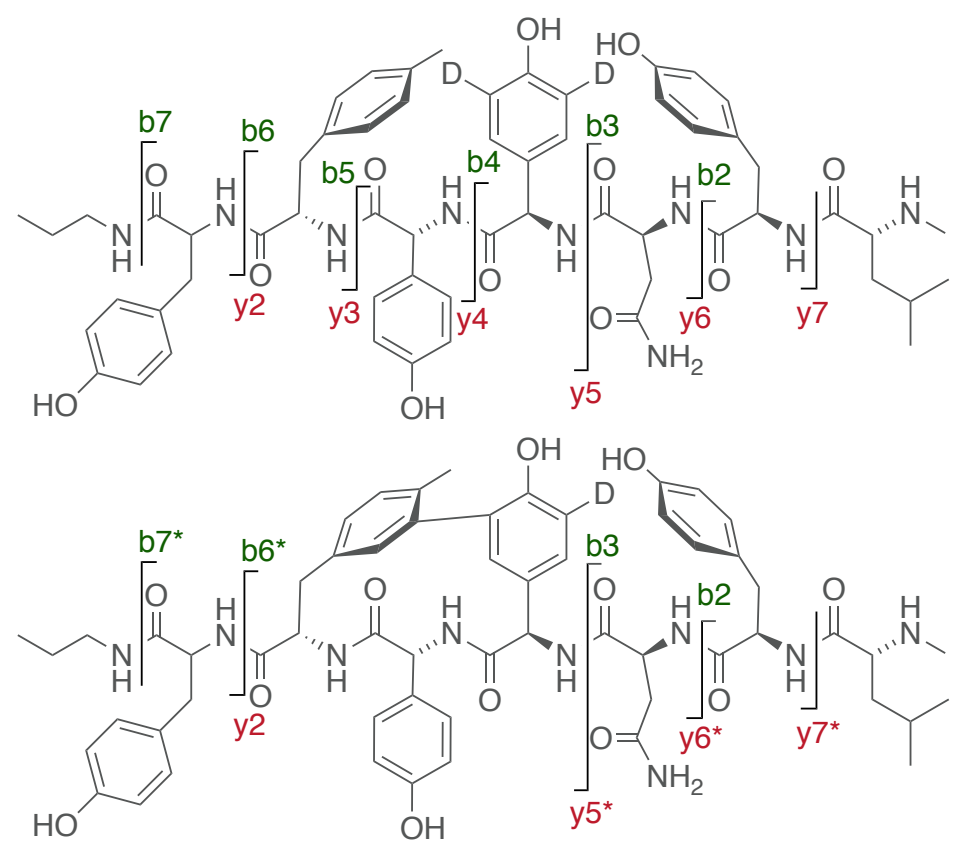

Figure S66. HR-MS/MS fragmentation for starting material with 4-Me-L-Phe as AA2 and ortho${ }^{2} \mathrm{H}_{2}$-D-Hpg as AA4 and -3 Da product upon reaction with OxyB (36). 


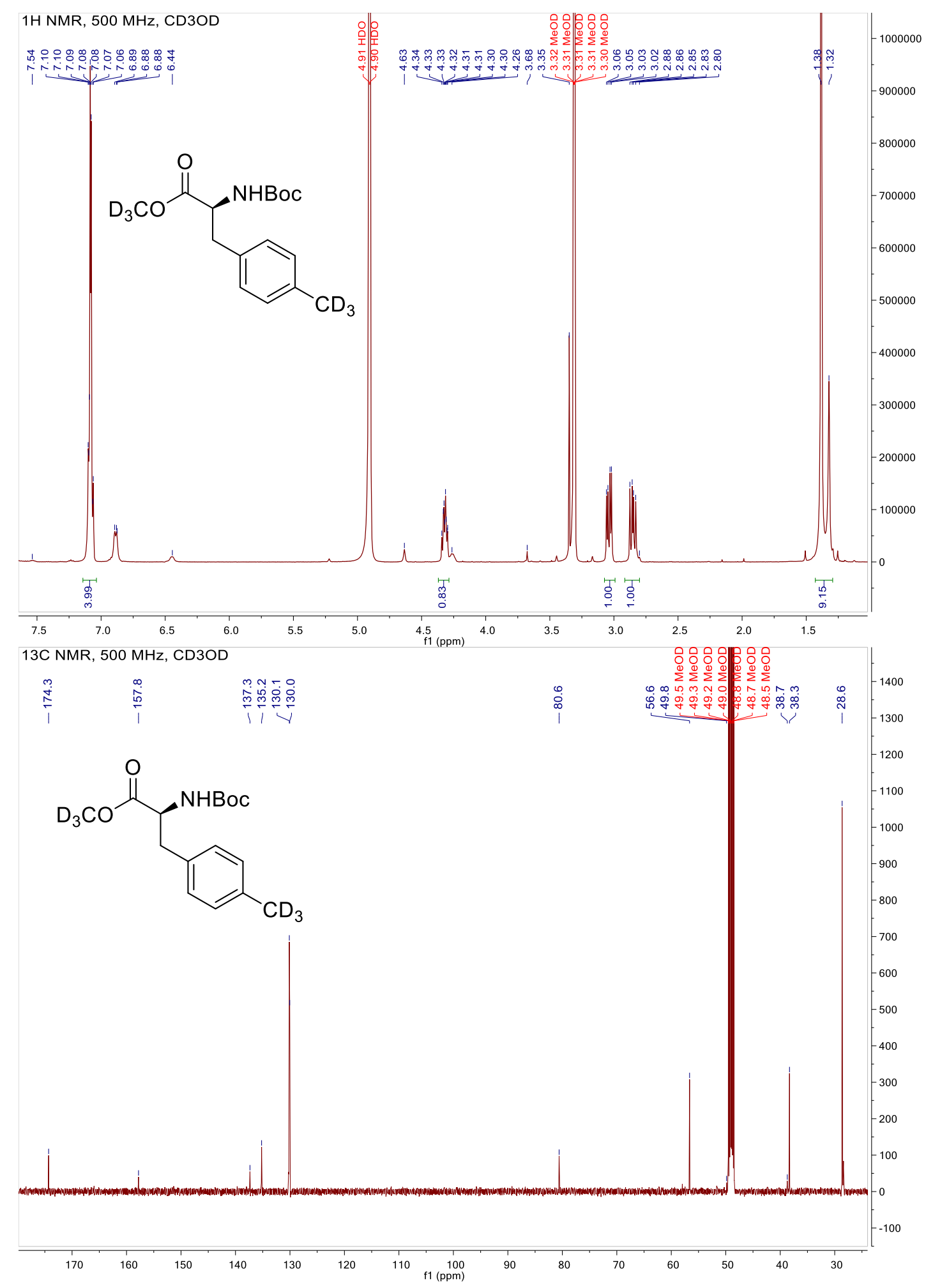

Figure S67. ${ }^{1} \mathrm{H}$ NMR spectrum (top) and ${ }^{13} \mathrm{C}$ NMR spectrum (bottom) of $N$-Boc-4-CD $3-\mathrm{L}-$ phenylalanine methyl ester. 


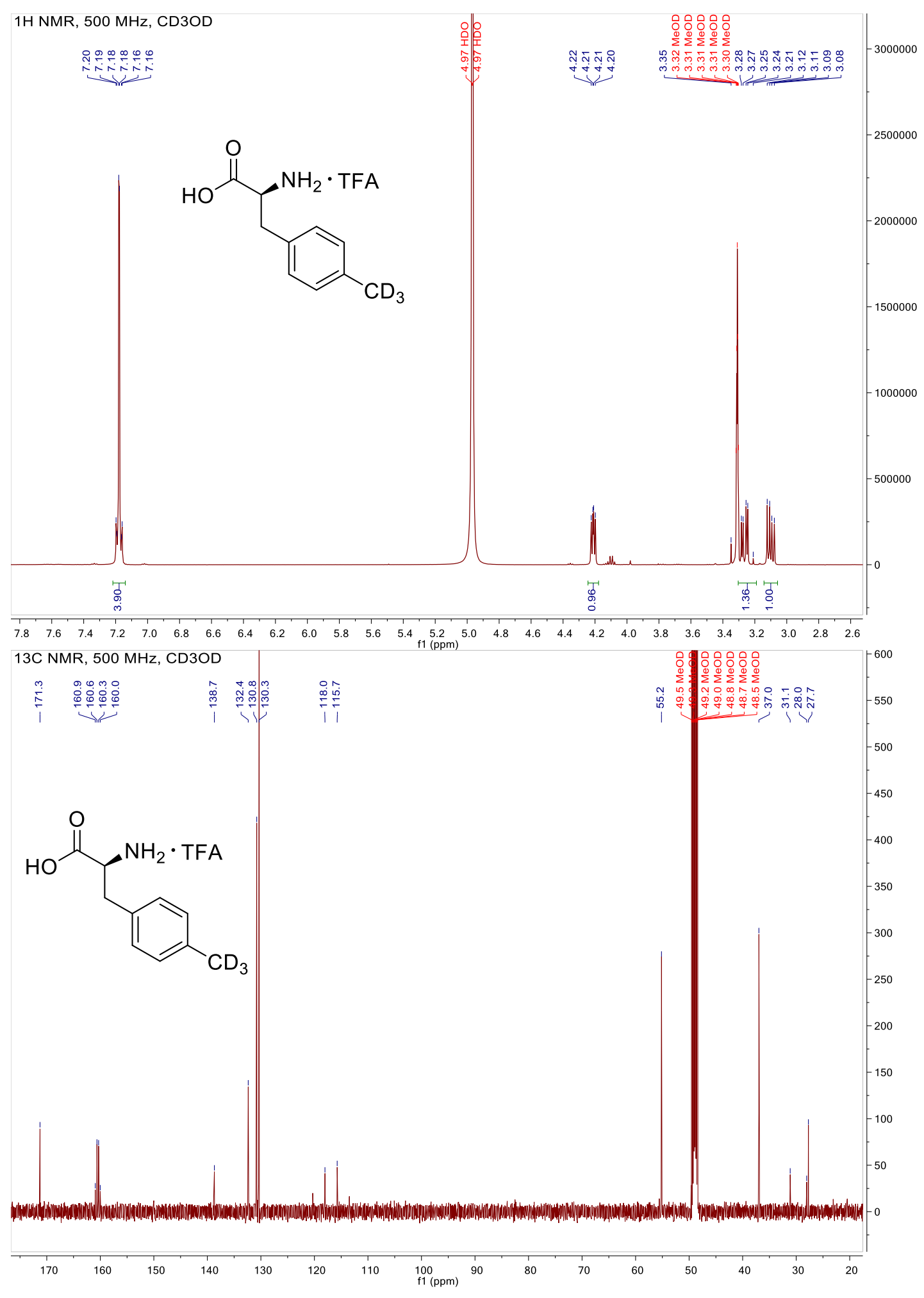

Figure S68. ${ }^{1} \mathrm{H}$ NMR spectrum (top) and ${ }^{13} \mathrm{C}$ NMR spectrum (bottom) of 4-CD $-\mathrm{L}-$ phenylalanine. 


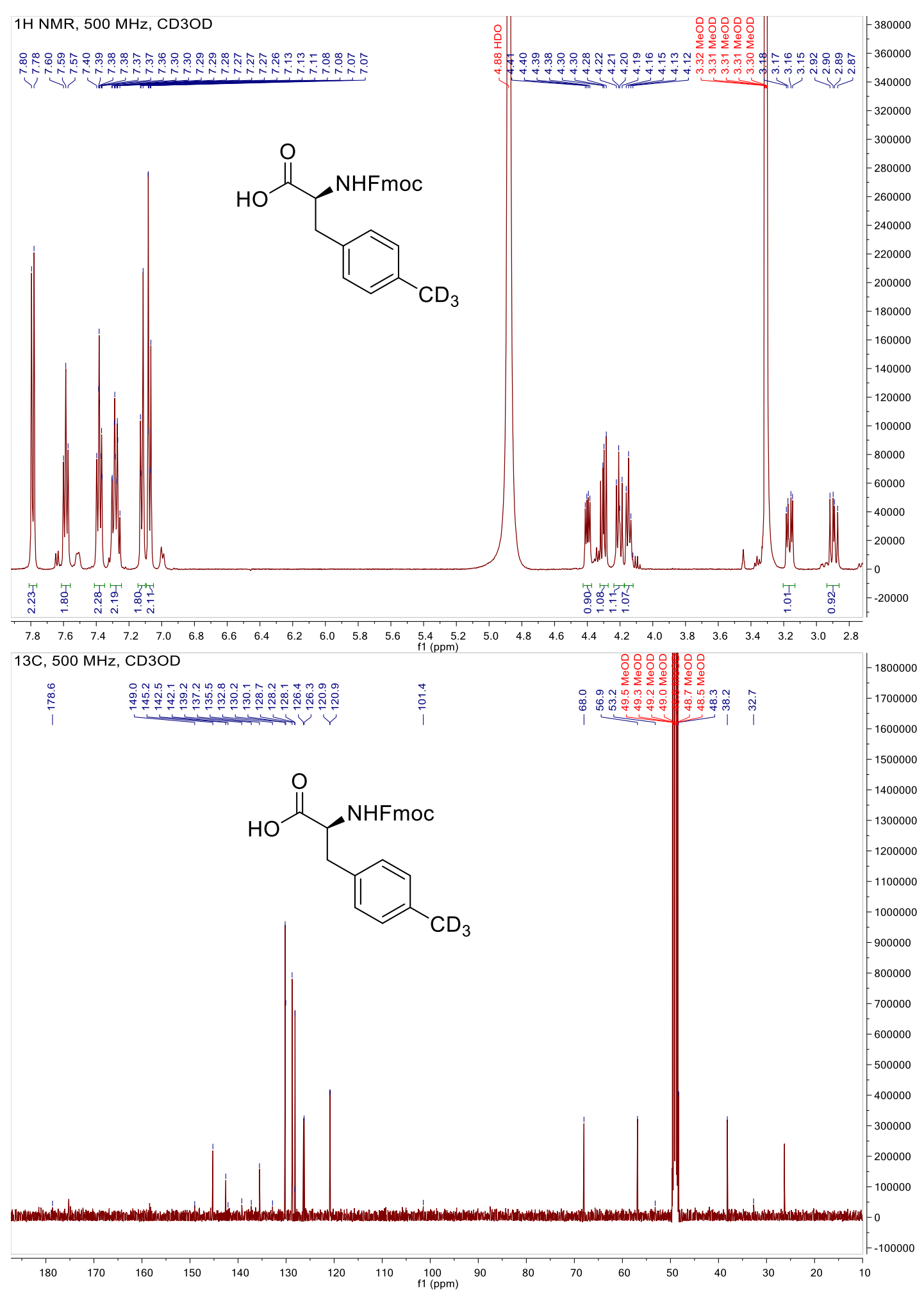

Figure S69. ${ }^{1} \mathrm{H}$ NMR spectrum (top) and ${ }^{13} \mathrm{C}$ NMR spectrum (bottom) of $N$-Fmoc-4-CD 3 -Lphenylalanine. 

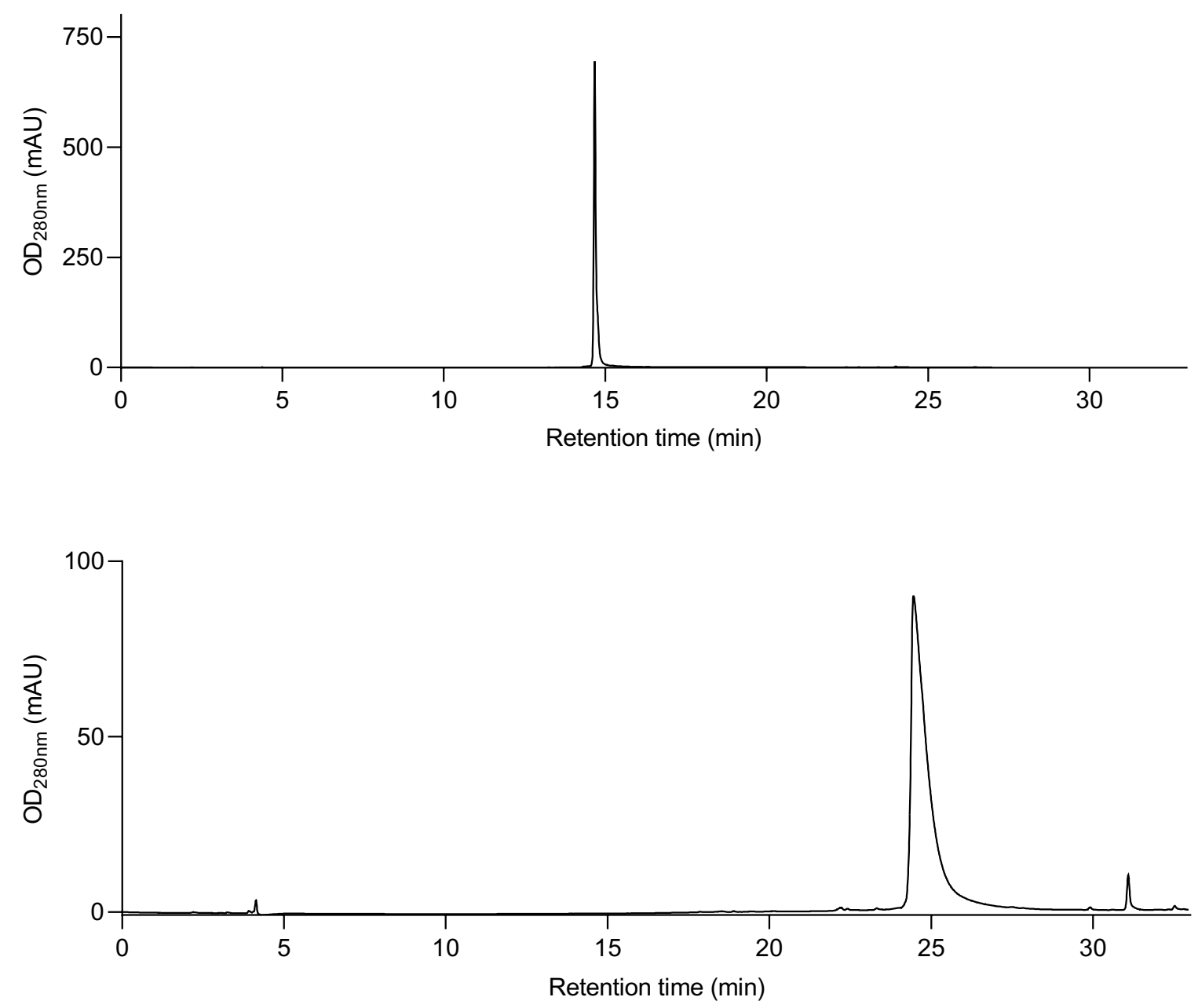

Figure S70. HPLC-MS analysis of pure peptide containing 4-C ${ }^{2} \mathrm{H}_{3}-\mathrm{L}-\mathrm{Phe} 2$ and D-Hpg4 (precursor to 37) as a 7 mer hydrazide (top) and as a CoA thioester adduct (bottom). 

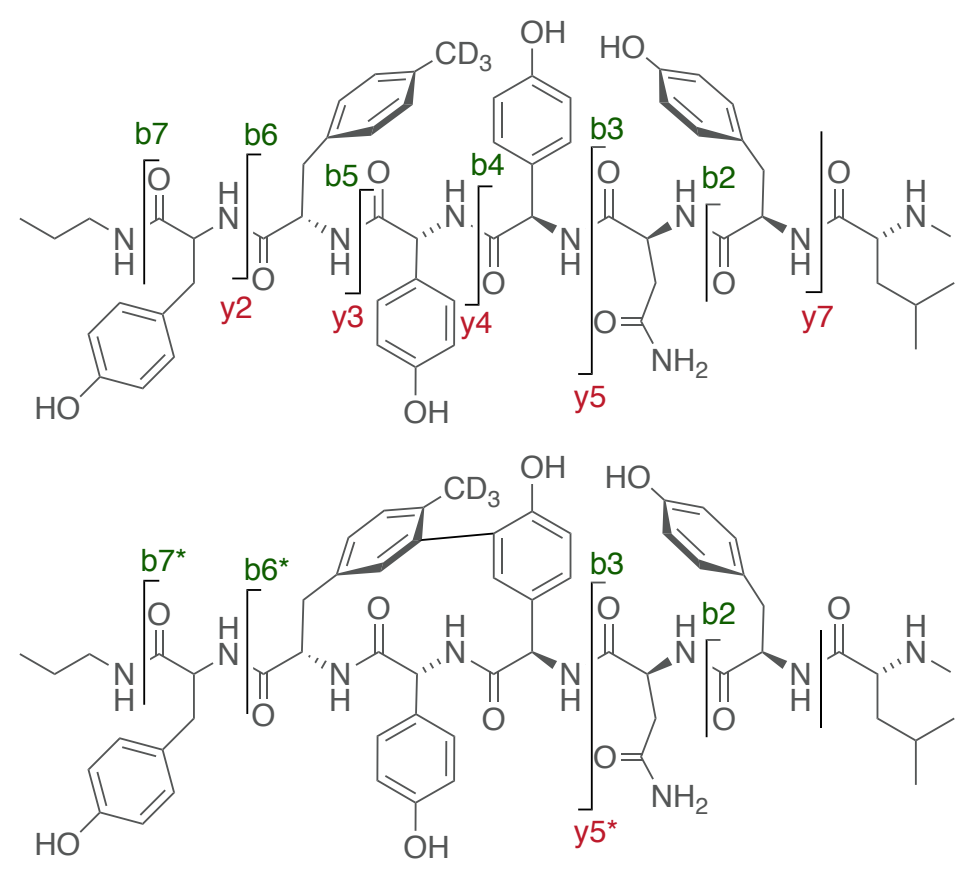

Figure S71. HR-MS/MS for starting material with 4-CD3-L-Phe as AA2 and D-Hpg as AA4 and -2 Da product upon reaction with OxyB (37). 

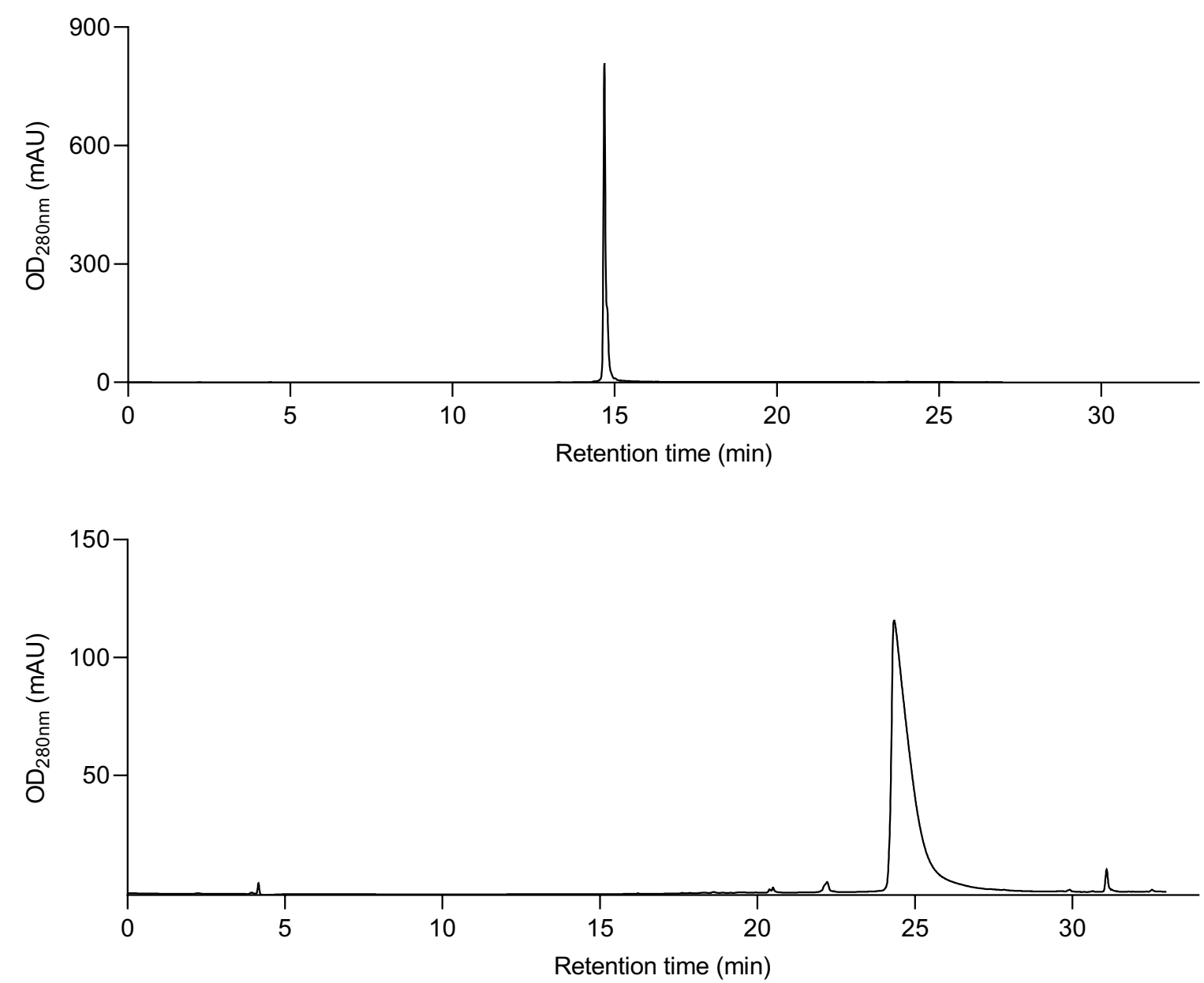

Figure S72. HPLC-MS analysis of pure peptide containing $4-\mathrm{C}^{2} \mathrm{H}_{3}-\mathrm{L}-\mathrm{Phe} 2$ and ortho- ${ }^{2} \mathrm{H}_{2}-\mathrm{D}-$ Hpg4 (precursor to 38) as a 7mer hydrazide (top) and as a CoA thioester adduct (bottom). 


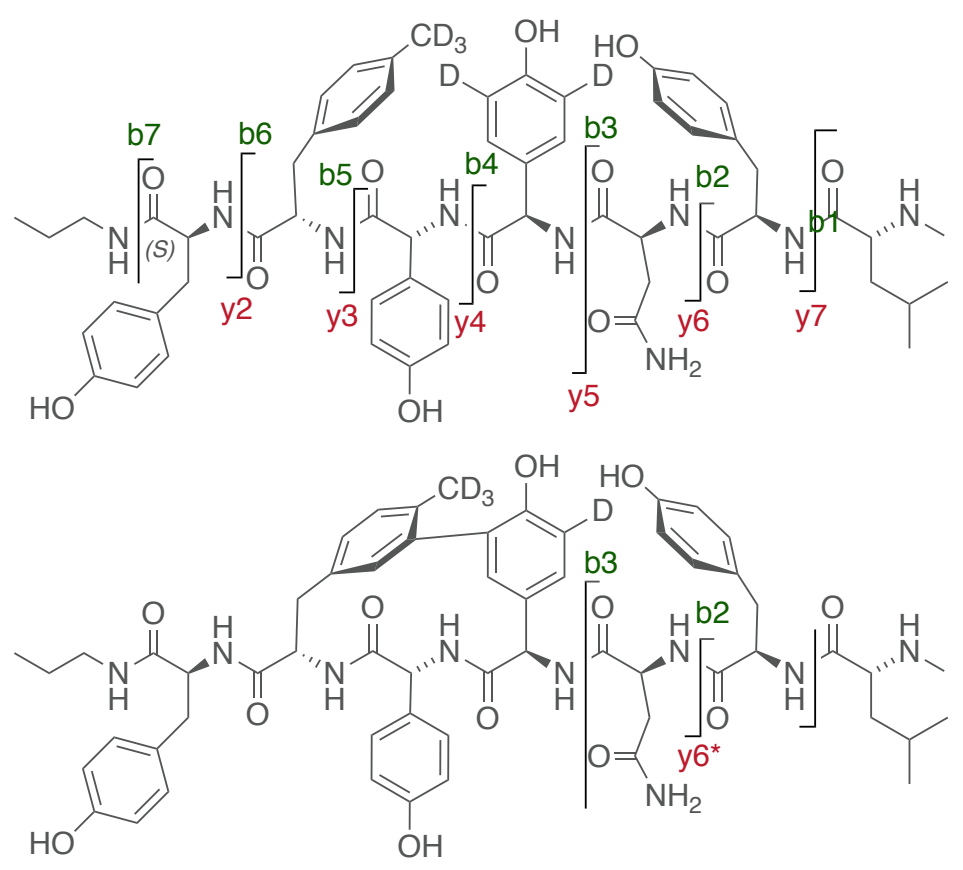

Figure S73. HR-MS/MS data for starting material AA2 $=4-\mathrm{CD}_{3}-\mathrm{L}-\mathrm{Phe}$ and $\mathrm{AA} 4=$ ortho- ${ }^{2} \mathrm{H}_{2}-\mathrm{D}-$ Hpg and -3 Da product upon reaction with OxyB (38). 


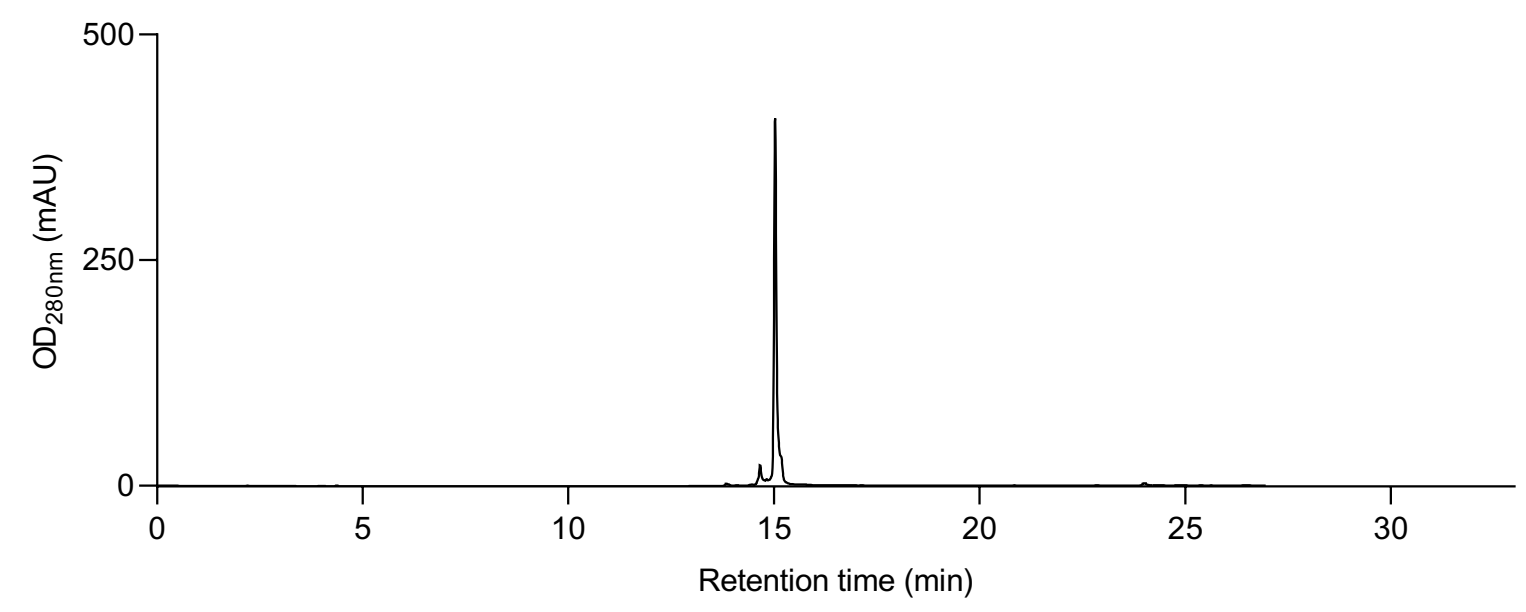

Figure S74. HPLC-MS analysis of pure peptide containing 4-C ${ }^{2} \mathrm{H}_{3}-\mathrm{L}-\mathrm{Phe} 2$ and D-PhGly4 (precursor to 41) as a 7mer hydrazide. Coenzyme A adduct of this peptide was purified via massdetected HPLC and pure fractions containing desired mass were collected and submitted to assays without further characterization. 

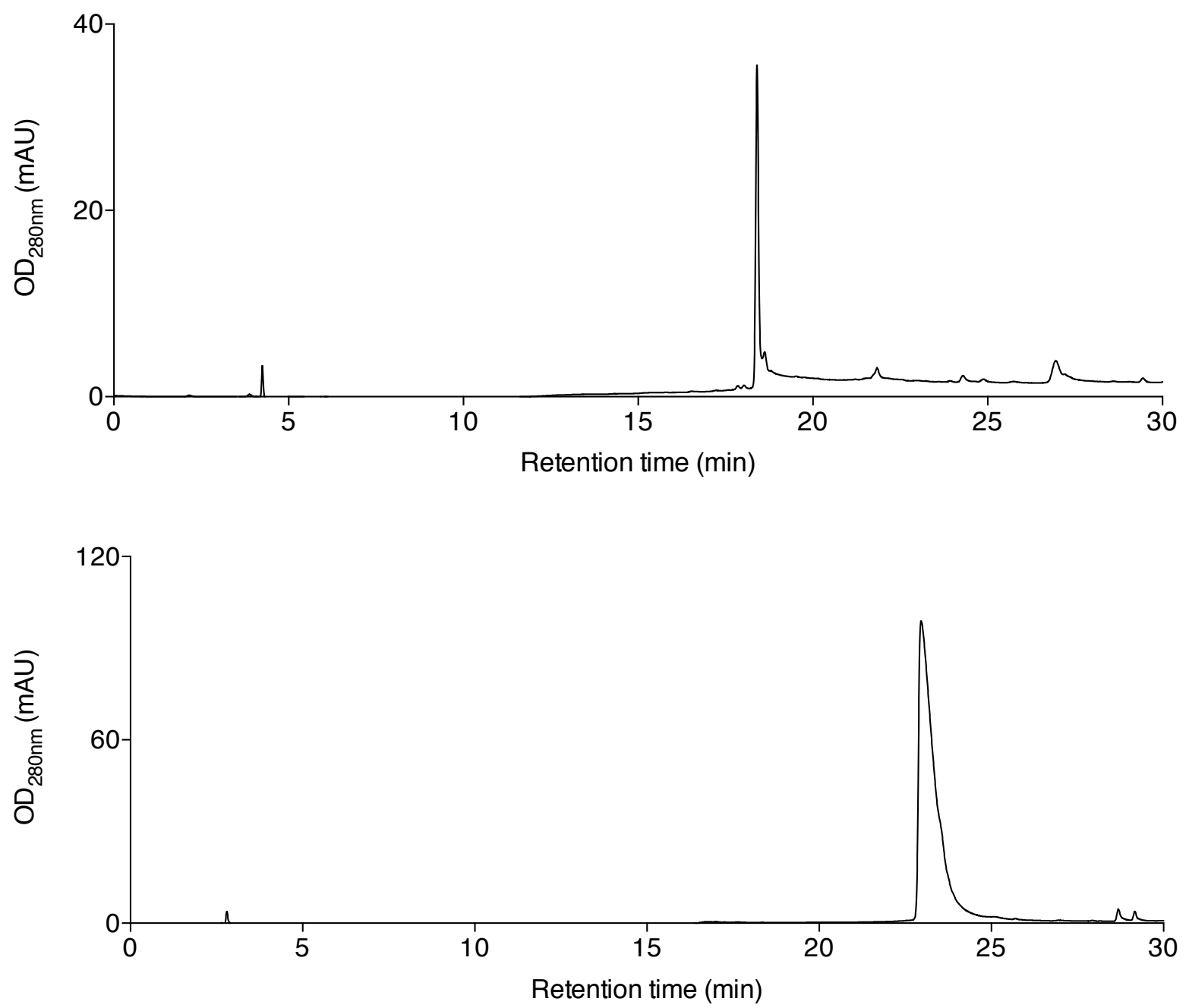

Figure S75. HPLC-MS analysis of pure peptide containing L-Phe2, ortho $-{ }^{2} \mathrm{H}_{2}-\mathrm{D}-\mathrm{Hpg} 3$ and DPhGly4 (precursor to 42) as a 7 mer hydrazide (top) and as a CoA thioester adduct (bottom). 

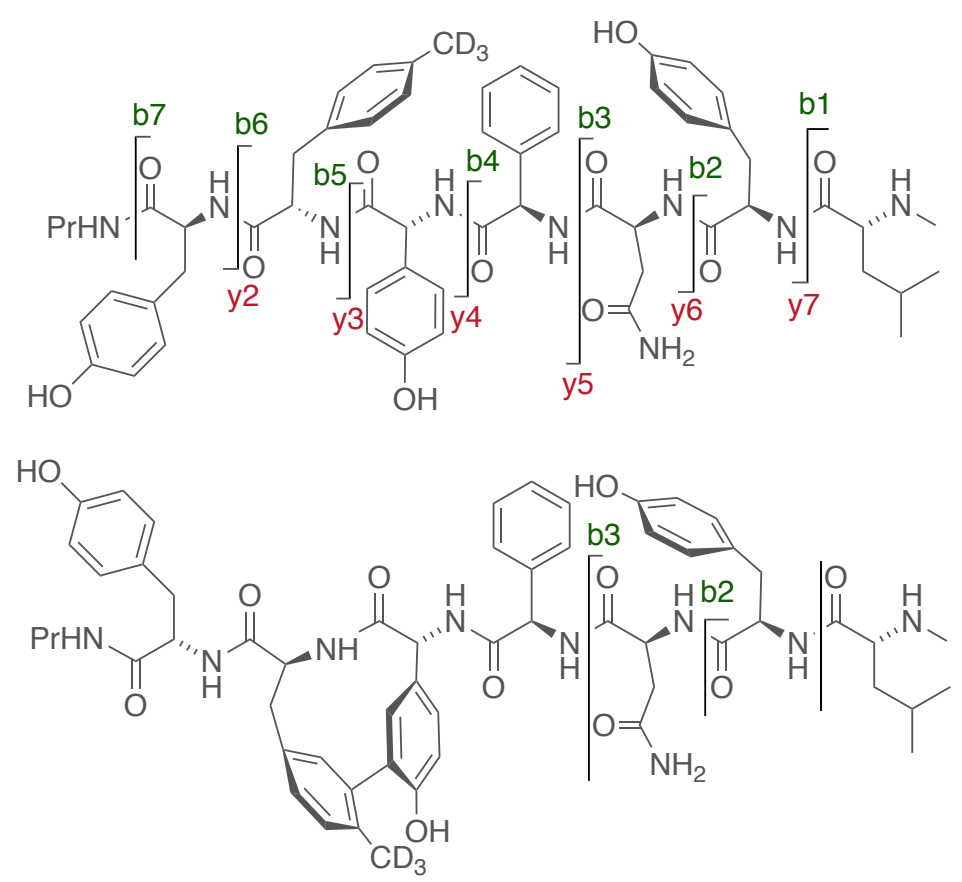

Figure S76. HR-MS/MS for starting material with AA2 $=4-\mathrm{CD}_{3}-\mathrm{L}-\mathrm{Phe}$ and AA4 $=$ D-PhGly and -2 Da product upon reaction with OxyB (41). 

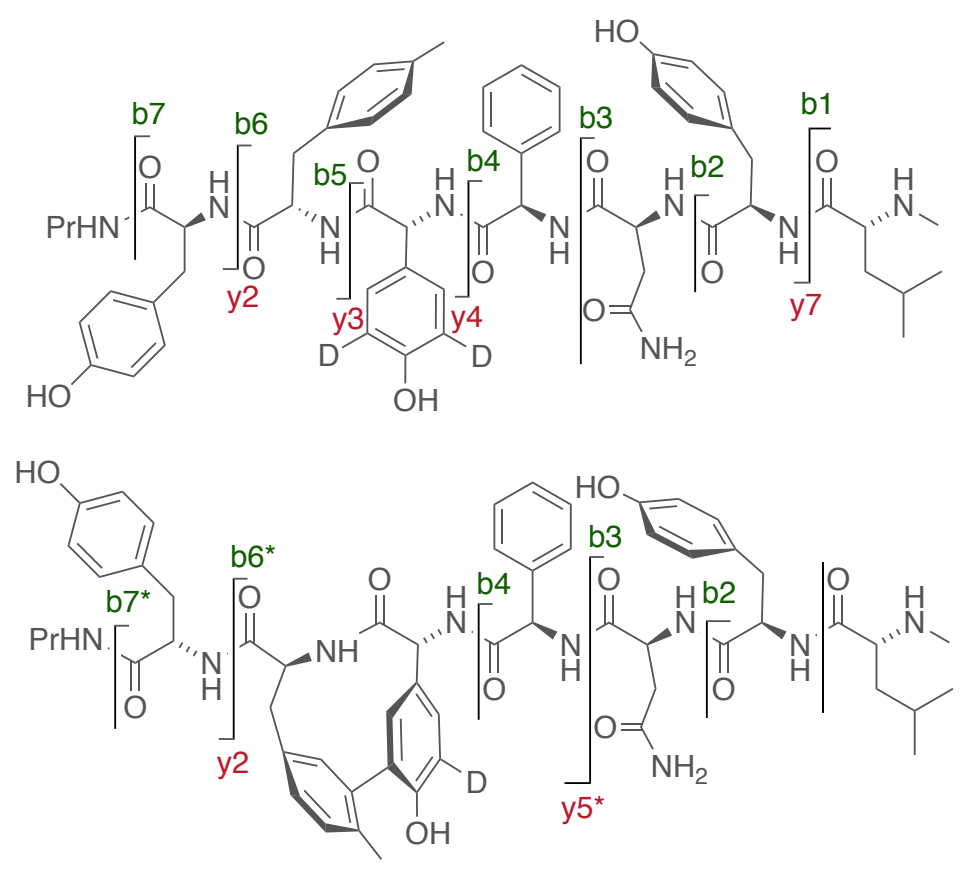

Figure S77. HR-MS/MS data for starting material AA2 $=\mathrm{L}-\mathrm{Phe}$, AA $3=$ ortho ${ }^{2} \mathrm{H}_{2}-\mathrm{D}-\mathrm{Hpg}, \mathrm{AA} 4$ $=\mathrm{D}-\mathrm{PhGly}$ and -3 Da product upon reaction with OxyB (42). 


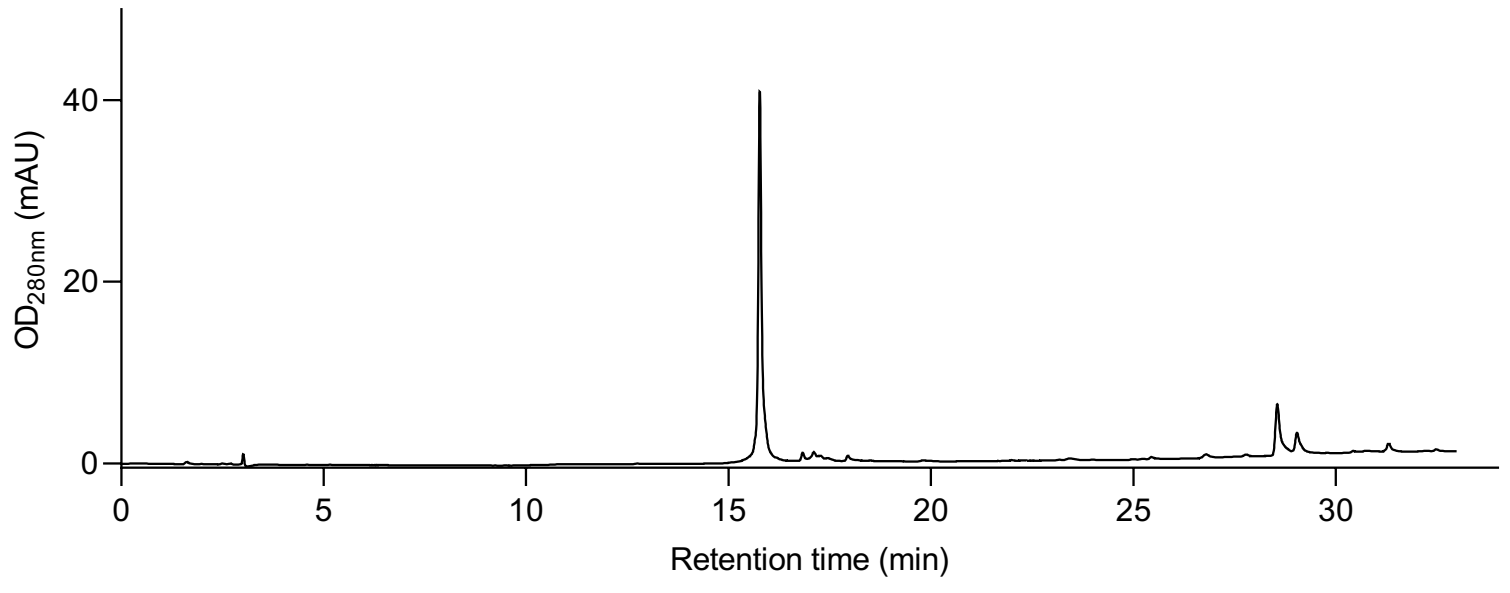

Figure S78. HPLC-MS analysis of pure peptide containing 4- $\mathrm{NH}_{2}-\mathrm{L}-\mathrm{Phe} 2$ and ortho $-{ }^{2} \mathrm{H}_{2}-\mathrm{D}-\mathrm{Hpg} 4$ (precursor to $\mathbf{4 5}$ ) as a $7 \mathrm{mer}$ CoA thioester adduct. 


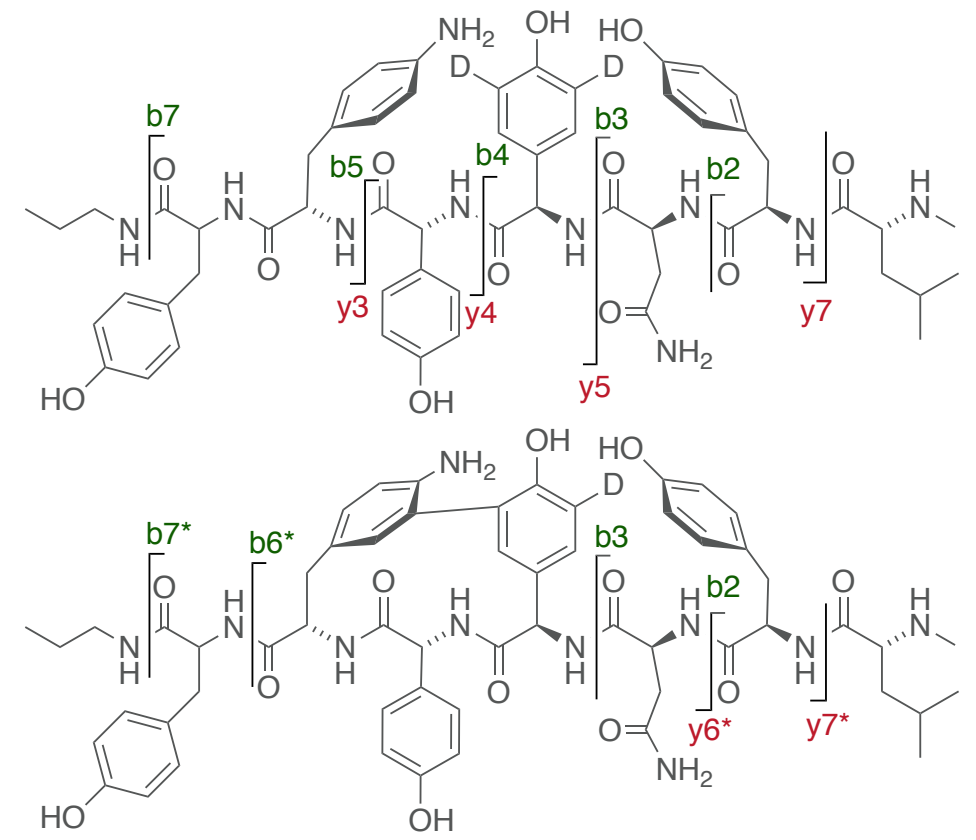

Figure S79. HR-MS/MS fragmentation for starting material with AA2 $=4-\mathrm{NH}_{2}-\mathrm{L}-\mathrm{Phe}$ and AA4 $=$ ortho $-{ }^{2} \mathrm{H}_{2}$-D-Hpg and -3 Da product upon reaction with OxyB (45). 

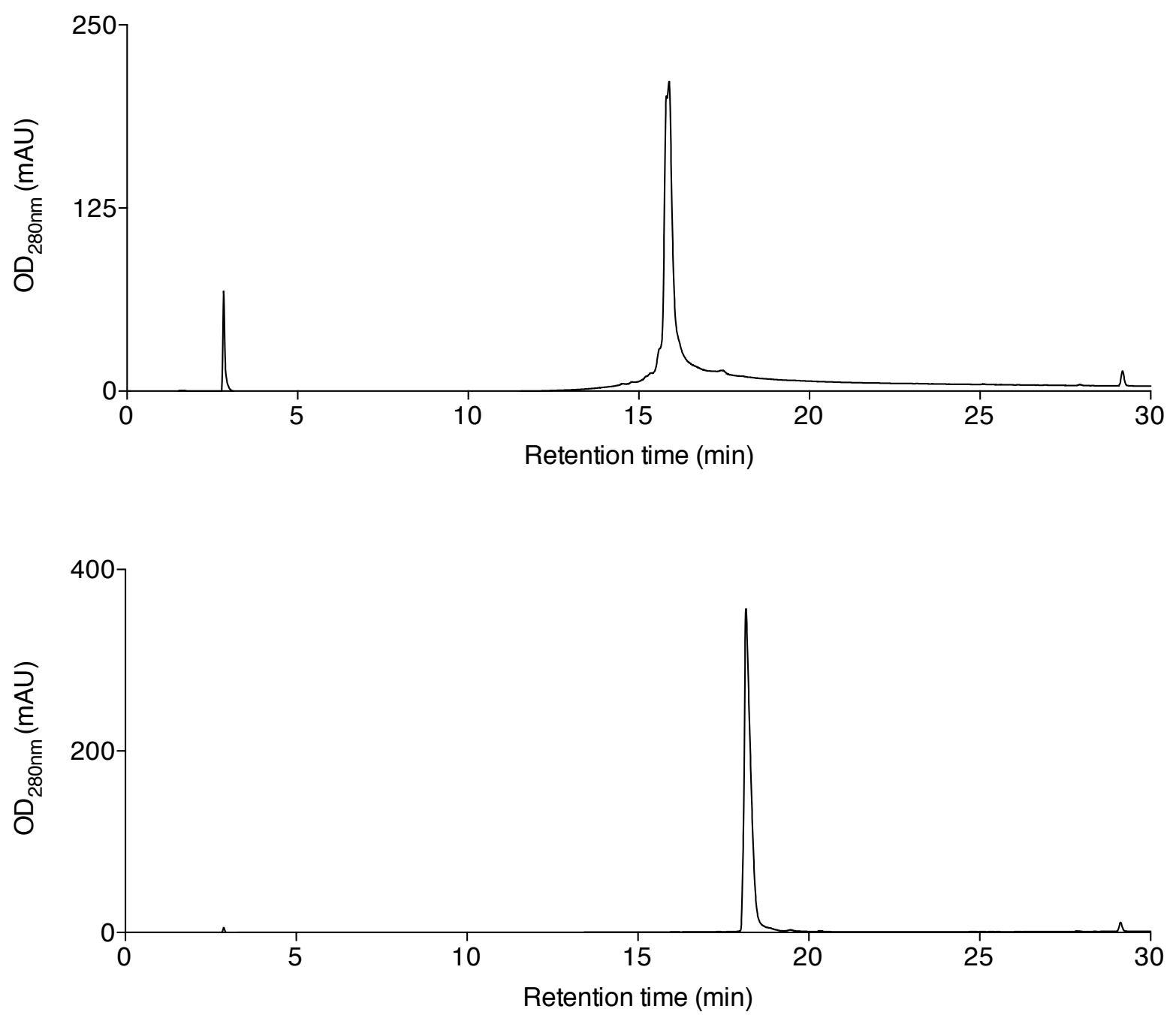

Figure S80. HPLC-MS analysis of pure $\mathbf{4 8}$ as a 7 mer hydrazide (top) and as a CoA thioester adduct (bottom). 

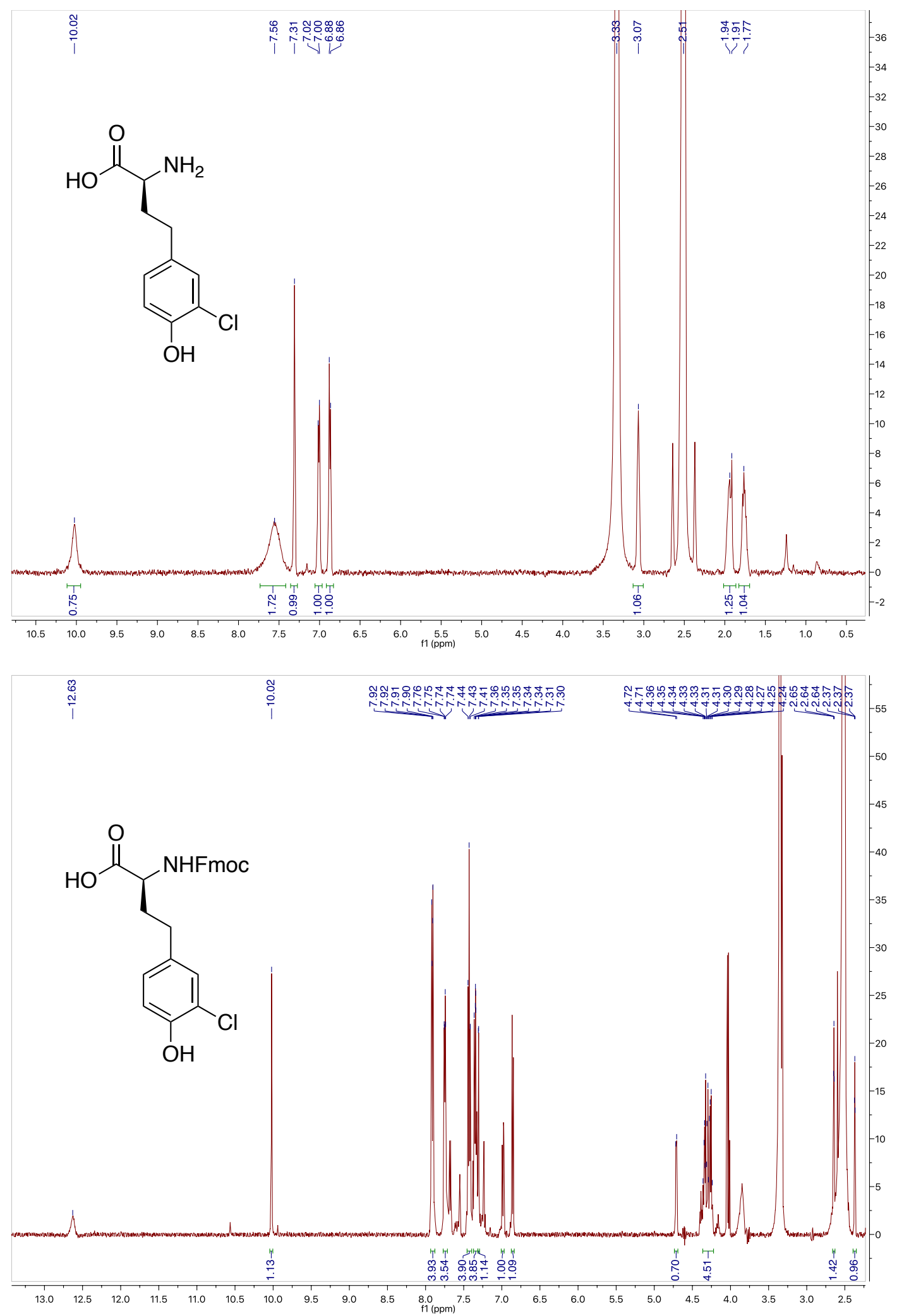

Figure S81. ${ }^{1} \mathrm{H}$ NMR spectrum for 3-Cl-L-homotyrosine (top) and ${ }^{1} \mathrm{H}$ NMR spectrum for $N$-Fmoc3-Cl-L-homotyrosine (bottom). 


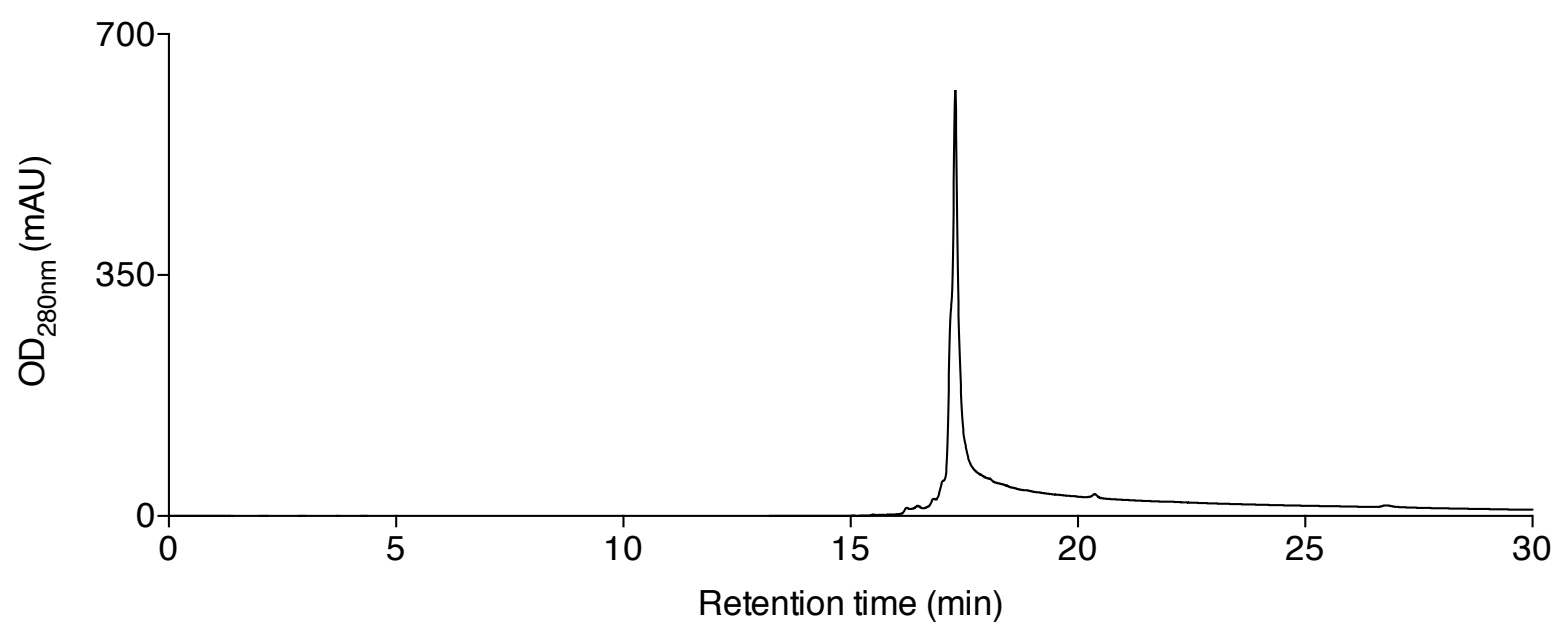

Figure S82. HPLC-MS analysis of pure $\mathbf{5 0}$ as a 7mer hydrazide. Coenzyme A adduct of this peptide was purified via mass-detected HPLC and pure fractions containing desired mass were collected and submitted to assays without further characterization. 

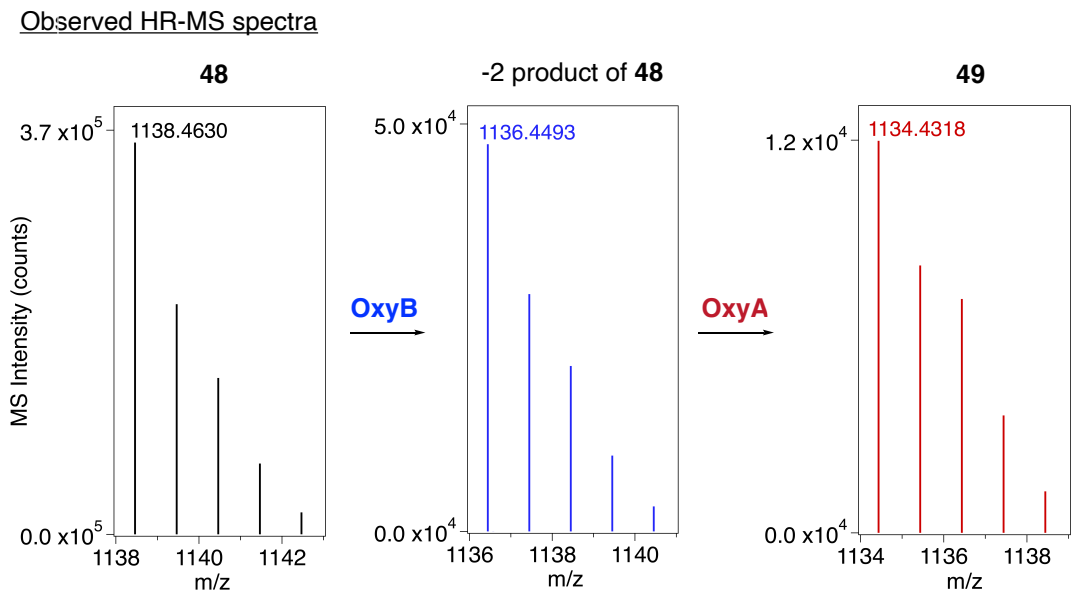

Calculated HR-MS spectra
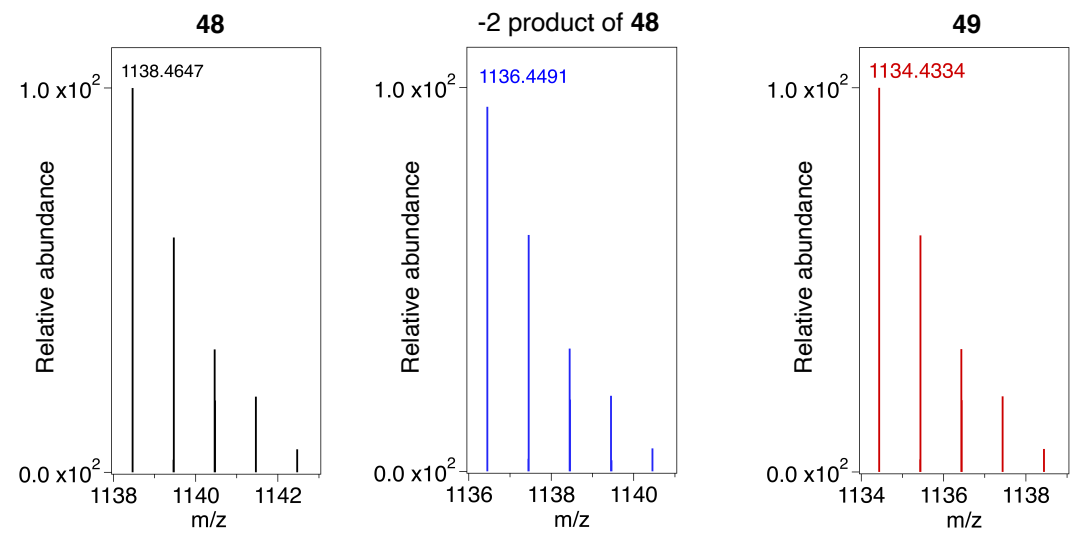

Figure S83. Observed and calculated HR-MS spectra for substrate $\mathbf{4 8}$ and its products upon reaction with OxyB and OxyA. 


\section{Observed HR-MS spectra}
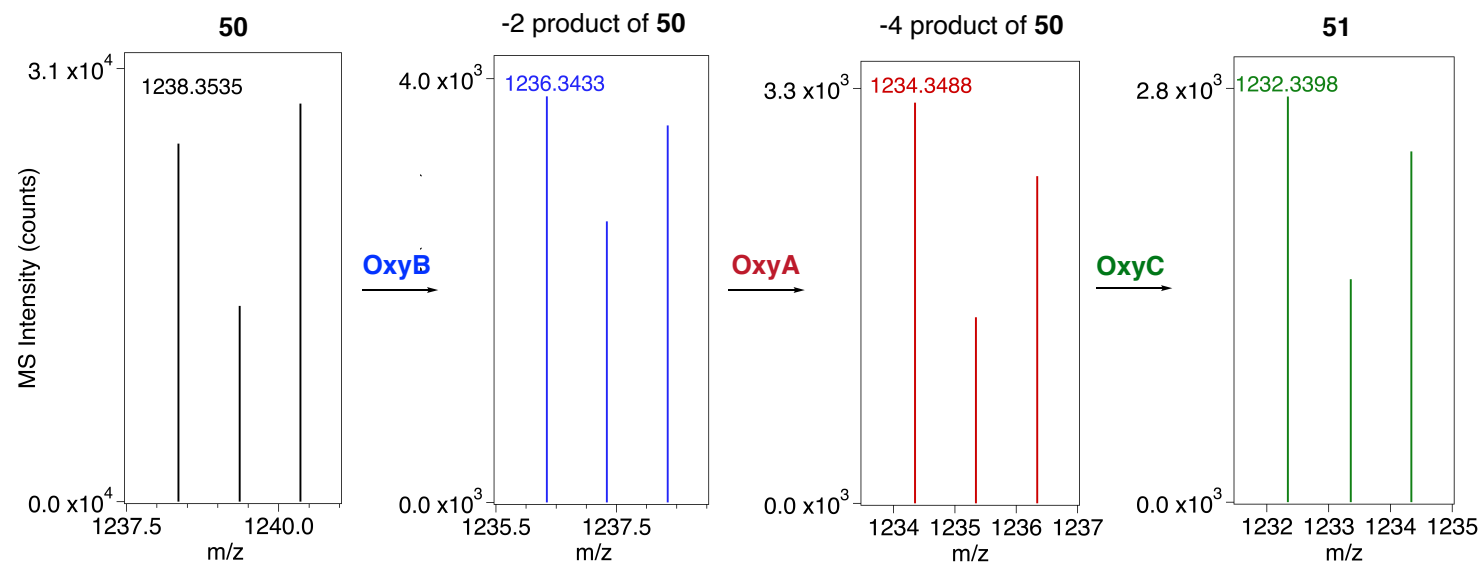

Calculated HR-MS spectra
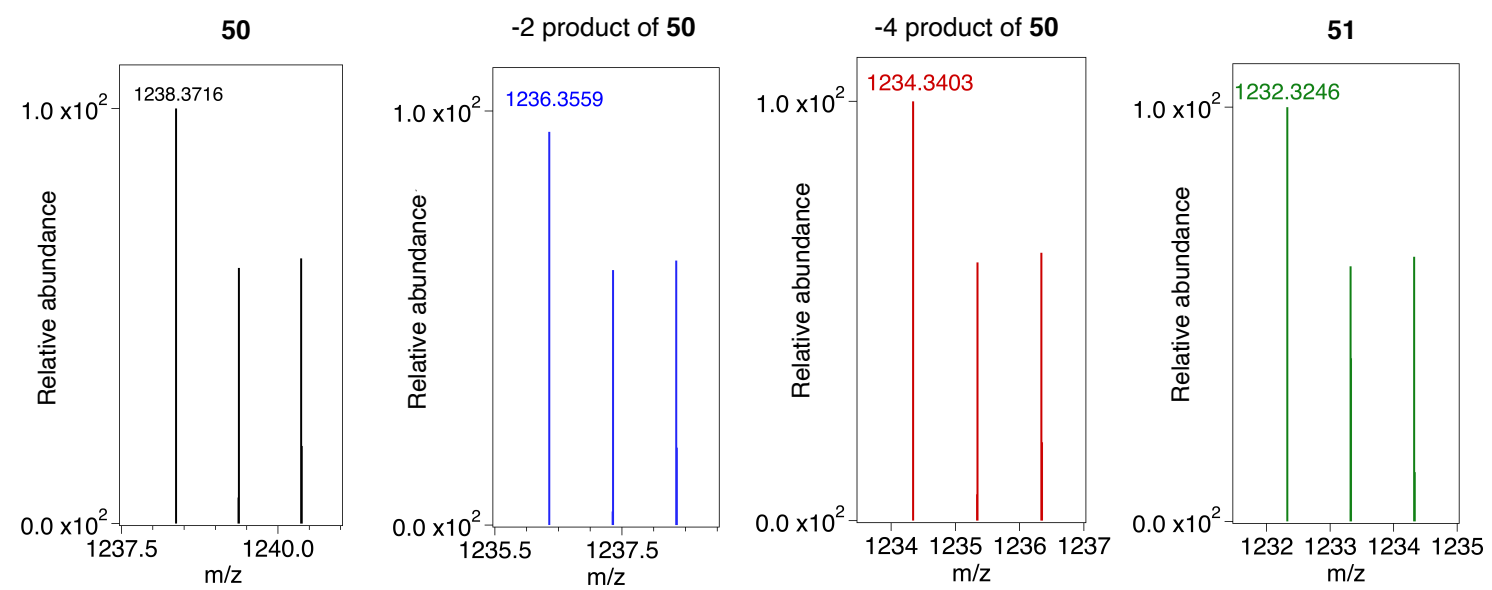

Figure S84. Observed and calculated HR-MS spectra for the trisodium salt of substrate $\mathbf{5 0}$ and its products upon reaction with OxyB, OxyA and OxyC. 

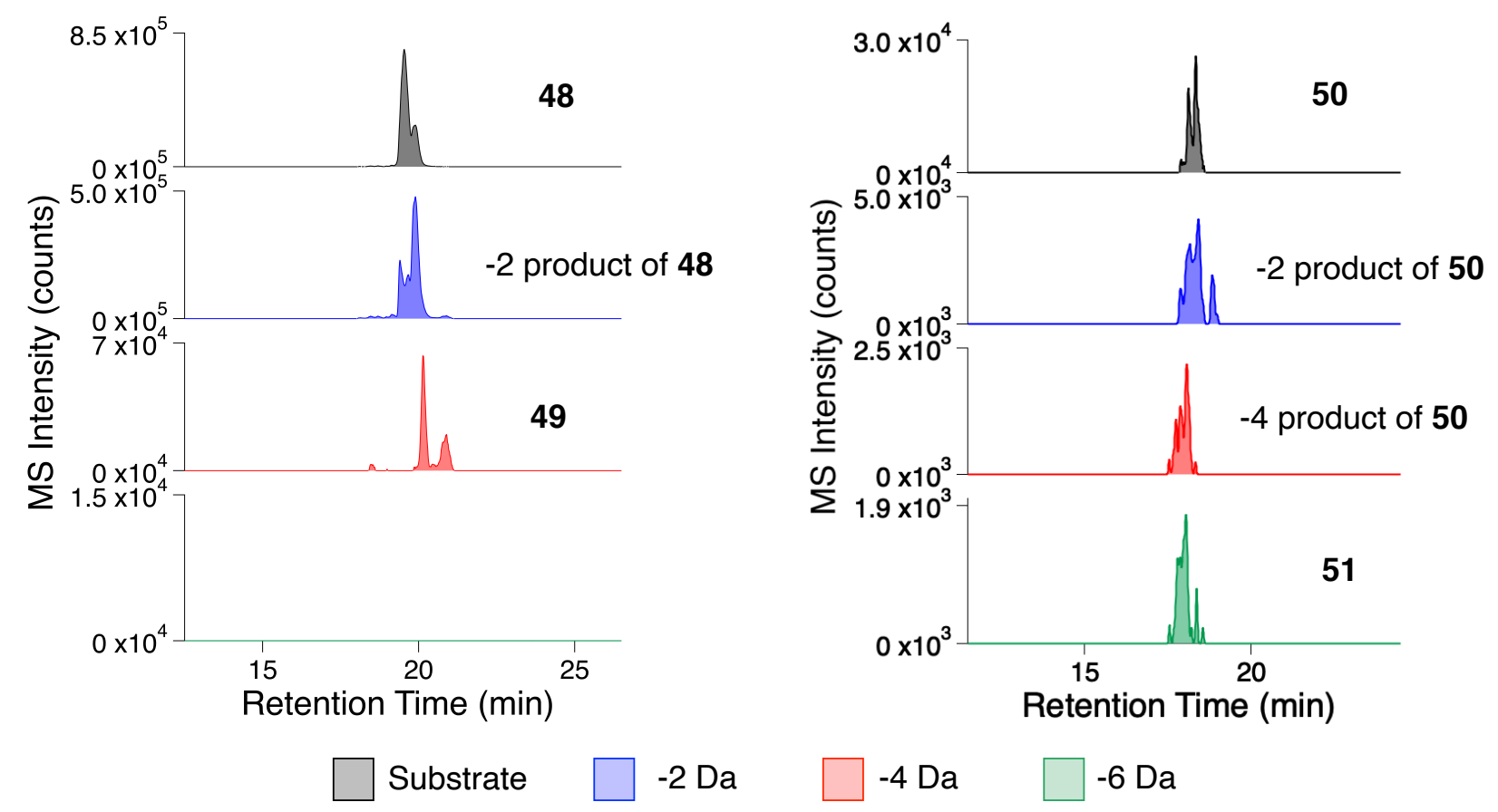

Figure S85. (Left) Extracted ion counts for derivatized substrate 48, monocrosslinked product from reaction of 48 with OxyB and bicyclic product 49. (Right) Extracted ion counts for derivatized substrate 50, monocrosslinked product from reaction of $\mathbf{5 0}$ with OxyB, bicyclic product from reaction of $\mathbf{5 0}$ with OxyB and OxyA, and tricyclic product 51. 
Table S1. HR-MS data for substrates and products of OxyB enzymatic reactions to generate analogs with varying macrocycle sizes and various stereochemistries. Sequence of peptides shown is (LTyr1)-AA2-(D-Hpg3)-AA4-(L-Asn5)-(D-Tyr6)-(N-Me-D-Leu7).

\begin{tabular}{|c|c|c|c|c|c|c|}
\hline Compound & AA2 & AA4 & $\begin{array}{c}\text { Charge } \\
\text { State }\end{array}$ & Calculated mass & Observed mass & $\Delta \mathbf{p p m}$ \\
\hline 4 & L-Hpg & D-Hpg & 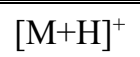 & 1074.4931 & 1074.49646 & 3.1 \\
\hline 5 & L-Hpg & D-Hpg & {$[\mathrm{M}+\mathrm{H}]^{+}$} & 1072.4775 & 1072.48163 & 3.9 \\
\hline 6 & L-Tyr & D-Tyr & {$[\mathrm{M}+\mathrm{H}]^{+}$} & 1102.5223 & 1102.52646 & 3.8 \\
\hline 7 & L-Tyr & D-Tyr & {$[\mathrm{M}+\mathrm{H}]^{+}$} & 1100.51 & 1100.50982 & 0.2 \\
\hline 8 & L-homoTyr & D-Hpg & {$[\mathrm{M}+\mathrm{H}]^{+}$} & 1102.5244 & 1102.52625 & 1.7 \\
\hline 9/10 & L-homoTyr & D-Hpg & {$[\mathrm{M}+\mathrm{H}]^{+}$} & 1100.5088 & 1100.5108 & 1.8 \\
\hline- & ${ }^{2} \mathrm{H}_{2}$-L-homoTyr & D-Hpg & {$[\mathrm{M}+\mathrm{H}]^{+}$} & 1104.537 & 1104.53553 & 1.3 \\
\hline 11 & ${ }^{2} \mathrm{H}_{2}$-L-homoTyr & D-Hpg & {$[\mathrm{M}+\mathrm{H}]^{+}$} & 1102.5213 & 1102.528 & 6.1 \\
\hline 12 & ${ }^{2} \mathrm{H}_{2}$-L-homoTyr & D-Hpg & {$[\mathrm{M}+\mathrm{H}]^{+}$} & 1101.515 & 1101.52318 & 7.4 \\
\hline- & L-homoTyr & ${ }^{2} \mathrm{H}_{2}$-D-Hpg & {$[\mathrm{M}+\mathrm{H}]^{+}$} & 1104.5369 & 1104.54332 & 5.8 \\
\hline 13 & L-homoTyr & ${ }^{2} \mathrm{H}_{2}$-D-Hpg & {$[\mathrm{M}+\mathrm{H}]^{+}$} & 1102.5213 & 1102.53378 & 11.3 \\
\hline 14 & L-homoTyr & ${ }^{2} \mathrm{H}_{2}$-D-Hpg & {$[\mathrm{M}+\mathrm{H}]^{+}$} & 1101.515 & 1101.52832 & 12.1 \\
\hline 15 & L-Tyr & L-Hpg & {$[\mathrm{M}+\mathrm{H}]^{+}$} & 1088.5088 & 1088.51177 & 2.7 \\
\hline 16 & L-Tyr & L-Hpg & {$[\mathrm{M}+\mathrm{H}]^{+}$} & 1086.4931 & 1086.49495 & 1.7 \\
\hline 17 & D-Tyr & D-Hpg & {$[\mathrm{M}+\mathrm{H}]^{+}$} & 1088.5088 & 1088.50973 & 0.8 \\
\hline 18 & D-Tyr & D-Hpg & {$[\mathrm{M}+\mathrm{H}]^{+}$} & 1086.4931 & 1086.4941 & 0.9 \\
\hline- & D-Tyr & ${ }^{2} \mathrm{H}_{2}$-D-Hpg & {$[\mathrm{M}+\mathrm{H}]^{+}$} & 1090.5213 & 1090.52589 & 4.2 \\
\hline 19 & D-Tyr & ${ }^{2} \mathrm{H}_{2}$-D-Hpg & {$[\mathrm{M}+\mathrm{H}]^{+}$} & 1087.4994 & 1087.50414 & 4.3 \\
\hline 20 & D-Tyr & L-Hpg & {$[\mathrm{M}+\mathrm{H}]^{+}$} & 1088.5088 & 1088.51149 & 2.4 \\
\hline $21 / 22$ & D-Tyr & L-Hpg & {$[\mathrm{M}+\mathrm{H}]^{+}$} & 1086.4931 & 1086.49454 & 1.3 \\
\hline- & D-Tyr & ${ }^{2} \mathrm{H}_{2}-\mathrm{L}-\mathrm{Hpg}$ & {$[\mathrm{M}+\mathrm{H}]^{+}$} & 1090.5213 & 1090.52889 & 6.9 \\
\hline 23 & D-Tyr & ${ }^{2} \mathrm{H}_{2}-\mathrm{L}-\mathrm{Hpg}$ & {$[\mathrm{M}+\mathrm{H}]^{+}$} & 1088.5057 & 1088.50927 & 3.2 \\
\hline 24 & D-Tyr & ${ }^{2} \mathrm{H}_{2}-\mathrm{L}-\mathrm{Hpg}$ & {$[\mathrm{M}+\mathrm{H}]^{+}$} & 1087.4994 & 1087.5074 & 7.3 \\
\hline
\end{tabular}


Table S2. HR-MS/MS data for 4 and its product upon reaction with OxyB, 5.

HR-MS/MS for substrate 4 ( $A A 2=L-H p g ; A A 4=D-H p g)$

\begin{tabular}{ccccl}
\hline $\begin{array}{c}\text { Charge } \\
\text { State }\end{array}$ & $\begin{array}{c}\text { Calculated } \\
\mathbf{m} / \mathbf{z}\end{array}$ & $\begin{array}{c}\text { Observed } \\
\mathbf{m} / \mathbf{z}\end{array}$ & \multicolumn{1}{|c}{ ppm } & \multicolumn{1}{c}{ Sequence } \\
\hline $\mathbf{b}_{2}{ }^{+1}$ & 291.1709 & 291.1755 & 15.8 & MeLeu-Tyr \\
$\mathbf{b}_{3}{ }^{+1}$ & 405.2138 & 405.2201 & 15.7 & MeLeu-Tyr-Asn \\
$\mathbf{b}_{4}{ }^{+1}$ & 554.2615 & 554.2704 & 16.0 & MeLeu-Tyr-Asn-Hpg \\
$\mathbf{b}_{5}{ }^{+1}$ & 703.3092 & 703.3182 & 12.9 & MeLeu-Tyr-Asn-Hpg-Hpg \\
$\mathbf{b}_{6}{ }^{+1}$ & 852.3568 & 852.3691 & 14.5 & MeLeu-Tyr-Asn-Hpg-Hpg-Hpg-Tyr \\
$\mathbf{b}_{7}{ }^{+1}$ & 1015.4202 & 1015.4264 & 6.1 & MeLeu-Tyr-Asn-Hpg-Hpg-Hpg-Tyr \\
\hline $\mathbf{y}_{2}{ }^{+1}$ & 223.1436 & 223.1481 & 20.5 & Tyr-propyl \\
$\mathbf{y}_{3}{ }^{+1}$ & 372.1912 & 371.197 & 15.6 & Hpg-Tyr-propyl \\
$\mathbf{y}_{4}{ }^{+1}$ & 521.2389 & 521.2479 & 17.4 & Hpg-Hpg-Tyr-propyl \\
$\mathbf{y}_{5}{ }^{+1}$ & 670.2866 & 670.2956 & 13.4 & Asn-Hpg-Hpg-Hpg-Tyr-propyl \\
$\mathbf{y}_{7}{ }^{+1}$ & 947.3928 & 947.4057 & 13.6 & Tyr-Asn-Hpg-Hpg-Hpg-Tyr-propyl \\
\hline
\end{tabular}

HR-MS/MS for product $5(A A 2=L-H p g ; A A 4=D-H p g)$

\begin{tabular}{|c|c|c|c|c|}
\hline $\begin{array}{c}\text { Charge } \\
\text { State }\end{array}$ & $\begin{array}{c}\text { Calculated } \\
\mathbf{m} / \mathbf{z}\end{array}$ & $\begin{array}{c}\text { Observed } \\
\mathbf{m} / \mathbf{z}\end{array}$ & $\Delta \mathbf{p p m}$ & Sequence \\
\hline $\mathbf{b}_{2}{ }^{+1}$ & 291.1709 & 291.1759 & 17.4 & MeLeu-Tyr \\
\hline$b_{3}{ }^{+1}$ & 405.2138 & 405.2203 & 16.1 & MeLeu-Tyr-Asn \\
\hline $\mathrm{b}_{6}{ }^{+1}$ & 850.3212 & 850.3512 & 11.8 & MeLeu-Tyr-Asn-Hpg \\
\hline $\mathbf{b}_{7}{ }^{+1}$ & 1013.4045 & 1013.4183 & 13.6 & MeLeu-Tyr-Asn-Hpg $-H p g-H p g_{m}$ \\
\hline $\mathbf{y}_{2}{ }^{+1}$ & 223.1436 & 223.1475 & 17.5 & Tyr-propyl \\
\hline $\mathbf{y}_{5}^{+1}$ & 668.2709 & 668.2848 & 20.9 & $\mathrm{Hpg}_{\mathrm{m}}-\mathrm{Hpg}-\mathrm{Hpg}_{\mathrm{m}}$-Tyr-propyl \\
\hline $\mathbf{y}_{6}{ }^{+1}$ & 782.3139 & 782.323 & 11.6 & Asn-Hpg ${ }_{m}-H p g-H p g_{m}-$ Tyr-propyl \\
\hline $\mathbf{y}_{7}^{+1}$ & 945.3772 & 945.3873 & 10.7 & 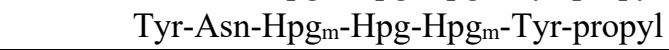 \\
\hline
\end{tabular}


Table S3. NMR assignments for 4 in $\left(\mathrm{CD}_{3}\right)_{2} \mathrm{SO}$ from $\mathrm{C}$ - to $\mathrm{N}$-terminus. The structure and number scheme for the compound is shown below the table.

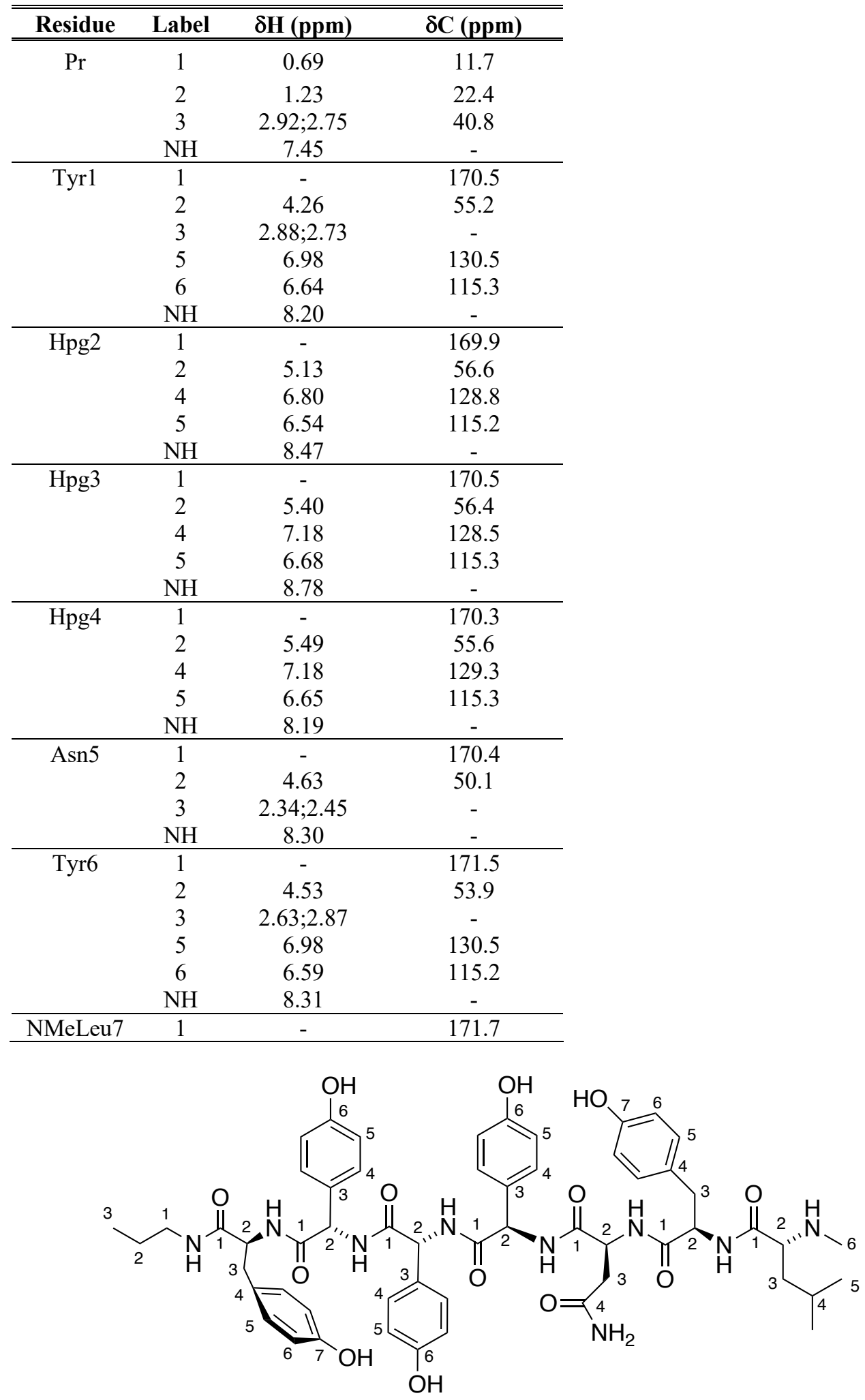


Table S4. NMR assignments for 5 in $\left(\mathrm{CD}_{3}\right)_{2} \mathrm{SO}$ from $\mathrm{C}$ - to $\mathrm{N}$-terminus. The structure and number scheme for the compound is shown below the table.

\begin{tabular}{|c|c|c|c|}
\hline Residue & Label & $\delta \mathrm{H}(\mathrm{ppm})$ & $\delta \mathrm{C}$ (ppm) \\
\hline \multirow[t]{4}{*}{ Propyl } & 2 & 0.76 & 11.8 \\
\hline & 3 & 1.32 & 22.7 \\
\hline & 4 & 2.95 & - \\
\hline & $\mathrm{NH}$ & 7.98 & - \\
\hline \multirow[t]{4}{*}{ Tyr1 } & 2 & 4.49 & 55.1 \\
\hline & 3 & $2.73 ; 2.81$ & 63.3 \\
\hline & 5 & 7.00 & 130.6 \\
\hline & 6 & 6.65 & 115.3 \\
\hline \multirow[t]{3}{*}{ Hpg2 } & 2 & - & - \\
\hline & 4 & 7.39 & 131.8 \\
\hline & 5 & 6.92 & 123.6 \\
\hline \multirow[t]{4}{*}{ Hpg3 } & 2 & 5.28 & - \\
\hline & 4 & 7.06 & 127.9 \\
\hline & 5 & 6.71 & 115.8 \\
\hline & $\mathrm{NH}$ & 9.00 & - \\
\hline \multirow[t]{4}{*}{ Hpg4 } & 2 & - & - \\
\hline & 4 & 5.21 & 114.3 \\
\hline & 7 & 6.74 & 115.9 \\
\hline & 8 & 6.59 & 130.5 \\
\hline \multirow[t]{3}{*}{ Asn } & 2 & 4.65 & 50.3 \\
\hline & 3 & $2.36 ; 2.51$ & - \\
\hline & $\mathrm{NH}$ & 8.30 & - \\
\hline \multirow[t]{5}{*}{ Tyr6 } & 2 & 4.54 & 53.7 \\
\hline & 3 & $2.85 ; 2.61$ & - \\
\hline & 5 & 6.95 & 115.2 \\
\hline & 6 & 6.59 & 130.5 \\
\hline & $\mathrm{NH}$ & 7.89 & - \\
\hline
\end{tabular}

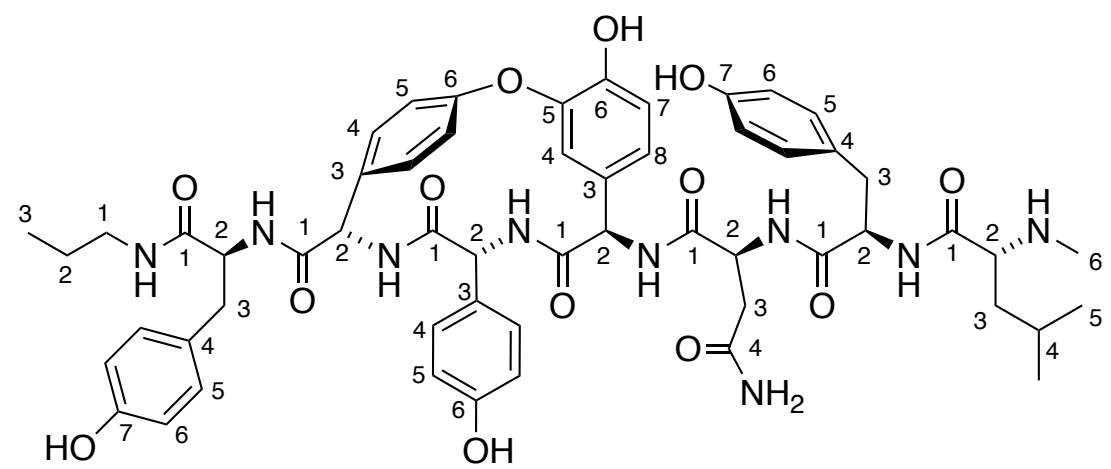


Table S5. Partial NMR assignment for vancomycin (1) in $\left(\mathrm{CD}_{3}\right)_{2} \mathrm{SO}$ and $2 \mathrm{D}$ correlations of relevant portions of the molecule ${ }^{7}$.

\begin{tabular}{|c|c|c|c|}
\hline Residue & Label & $\delta \mathrm{H}(\mathrm{ppm})$ & $\delta \mathrm{C}(\mathrm{ppm})$ \\
\hline \multirow[t]{4}{*}{ L-Dpg1 } & 2 & 4.42 & 56.7 \\
\hline & 6 & 6.42 & 102.3 \\
\hline & 8 & 6.26 & 105.8 \\
\hline & $\mathrm{NH}$ & 8.48 & - \\
\hline \multirow{5}{*}{ 3-Cl- $\beta-\mathrm{OH}-\mathrm{L}-\mathrm{Tyr} 2$} & 2 & 4.19 & 61.9 \\
\hline & 5 & 7.86 & 127.3 \\
\hline & 8 & 7.34 & 123.3 \\
\hline & 9 & 7.47 & 127.3 \\
\hline & $\mathrm{NH}$ & 6.67 & - \\
\hline \multirow[t]{5}{*}{ D-Hpg3 } & 2 & 4.43 & 53.7 \\
\hline & 4 & 7.18 & 135.6 \\
\hline & 7 & 6.72 & 116.2 \\
\hline & 8 & 6.77 & 125.4 \\
\hline & $\mathrm{NH}$ & 8.64 & - \\
\hline \multirow[t]{4}{*}{ D-Hpg4 } & 2 & 5.75 & 54.9 \\
\hline & 4 & 5.21 & 104.6 \\
\hline & 8 & 5.55 & 107.1 \\
\hline & $\mathrm{NH}$ & 8.25 & - \\
\hline
\end{tabular}

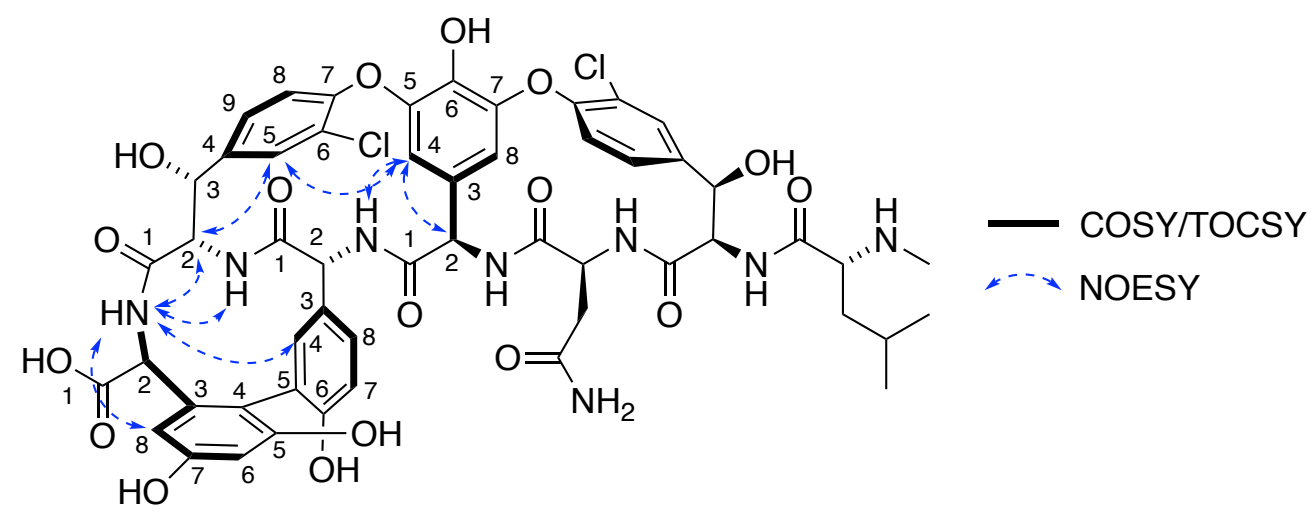


Table S6. HR-MS/MS data for 6 and its product upon reaction with OxyB, 7.

HR-MS/MS for substrate $6(A A 2=L-T y r ; A A 4=D-T y r)$

\begin{tabular}{ccccl}
\hline $\begin{array}{c}\text { Charge } \\
\text { State }\end{array}$ & $\begin{array}{c}\text { Calculated } \\
\mathbf{m} / \mathbf{z}\end{array}$ & $\begin{array}{c}\text { Observed } \\
\mathbf{m} / \mathbf{z}\end{array}$ & $\boldsymbol{\Delta} \mathbf{p p m}$ & \multicolumn{1}{c}{ Sequence } \\
\hline $\mathbf{b}_{2}{ }^{+1}$ & 291.1709 & 291.1672 & 12.4 & MeLeu-Tyr \\
$\mathbf{b}_{3}{ }^{+1}$ & 405.2138 & 405.2154 & 3.9 & MeLeu-Tyr-Asn \\
$\mathbf{b}_{4}{ }^{+1}$ & 568.2771 & 568.278 & 1.6 & MeLeu-Tyr-Asn-Tyr \\
$\mathbf{b}_{5}{ }^{+1}$ & 717.3248 & 717.3233 & 2.0 & MeLeu-Tyr-Asn-Tyr-Hpg \\
$\mathbf{b}_{6}{ }^{+1}$ & 880.3881 & 880.3851 & 3.3 & MeLeu-Tyr-Asn-Tyr-Hpg-Tyr \\
$\mathbf{b}_{7}{ }^{+1}$ & 1043.4458 & 1043.4515 & 5.4 & MeLeu-Tyr-Asn-Tyr-Hpg-Tyr-Tyr \\
\hline $\mathbf{y}_{2}{ }^{+1}$ & 223.1436 & 223.1326 & 4.9 & Tyr-propyl \\
$\mathbf{y}_{3}{ }^{+1}$ & 386.2069 & 386.2094 & 6.6 & Tyr-Tyr-propyl \\
$\mathbf{y}_{4}{ }^{+1}$ & 535.2546 & 535.2555 & 1.7 & Hpg-Tyr-Tyr-propyl \\
$\mathbf{y}_{5}{ }^{+1}$ & 698.3179 & 698.3137 & 5.9 & Tyr-Hpg-Tyr-Tyr-propyl \\
$\mathbf{y}_{6}{ }^{+1}$ & 812.3539 & 821.3608 & 8.4 & Asn-Tyr-Hpg-Tyr-Tyr-propyl \\
$\mathbf{y}_{7}{ }^{+1}$ & 975.4203 & 975.4241 & 3.8 & Tyr-Asn-Tyr-Hpg-Tyr-Tyr-propyl \\
\hline
\end{tabular}

HR-MS/MS for product $7(A A 2=L-T y r ; A A 4=D-T y r)$

\begin{tabular}{|c|c|c|c|c|}
\hline $\begin{array}{c}\text { Charge } \\
\text { State }\end{array}$ & $\begin{array}{c}\text { Calculated } \\
\mathbf{m} / \mathbf{z}\end{array}$ & $\begin{array}{c}\text { Observed } \\
\mathbf{m} / \mathbf{z}\end{array}$ & $\Delta$ ppm & Sequence \\
\hline $\mathbf{b}_{2}+1$ & 291.1709 & 291.1759 & 17.4 & MeLeu-Tyr \\
\hline $\mathbf{b}_{3}{ }^{+1}$ & 405.2138 & 405.2203 & 16.1 & MeLeu-Tyr-Asn \\
\hline$b_{6}{ }^{+1}$ & 850.3212 & 850.3512 & 11.8 & MeLeu-Tyr-Asn-Tyr ${ }_{m}-H p g-$ Tyr $_{m}$ \\
\hline $\mathbf{b}_{7}{ }^{+1}$ & 1013.4045 & 1013.4183 & 13.6 & MeLeu-Tyr-Asn-Tyrm-Hpg-Tyrm \\
\hline$y_{2}{ }^{+1}$ & 223.1436 & 223.1475 & 17.5 & Tyr-propyl \\
\hline $\mathbf{y}_{5}{ }^{+1}$ & 668.2709 & 668.2848 & 20.9 & Tyr $_{m}-H p g-$ Tyr $_{m}-$ Tyr-propyl \\
\hline $\mathrm{y}_{6}{ }^{+1}$ & 782.3139 & 782.323 & 11.6 & Asn-Tyrm-Hpg-Tyrm-Tyr-propyl \\
\hline$y_{7}+1$ & 945.3772 & 945.3873 & 10.7 & Tyr-Asn-Tyr ${ }_{m}-H p g-\operatorname{Tyr}_{m}-$ Tyr-propyl \\
\hline
\end{tabular}


Table S7. NMR assignments for 6 in $\left(\mathrm{CD}_{3}\right)_{2} \mathrm{SO}$ from $\mathrm{C}$ - to N-terminus. The structure and number scheme for the compound is shown below the table.

\begin{tabular}{|c|c|c|c|}
\hline Residue & Label & $\delta H(p p m)$ & $\delta \mathrm{C}(\mathrm{ppm})$ \\
\hline \multirow[t]{4}{*}{$\mathrm{Pr}$} & 1 & 0.74 & - \\
\hline & 2 & 1.32 & - \\
\hline & 3 & $2.88 ; 2.99$ & 40.7 \\
\hline & $\mathrm{NH}$ & 7.72 & 170.9 \\
\hline \multirow[t]{7}{*}{ Tyr1 } & 1 & - & 170.9 \\
\hline & 2 & 4.36 & 55.0 \\
\hline & 3 & $2.77 ; 2.84$ & 37.4 \\
\hline & 4 & - & 128.1 \\
\hline & 5 & 7.00 & 130.6 \\
\hline & 6 & 6.62 & 115.3 \\
\hline & $\mathrm{NH}$ & 8.14 & - \\
\hline \multirow[t]{6}{*}{ Tyr2 } & 1 & - & 171.1 \\
\hline & 2 & 4.57 & 54.2 \\
\hline & 3 & $2.60 ; 2.90$ & - \\
\hline & 5 & 7.00 & 130.6 \\
\hline & 6 & 6.61 & 115.3 \\
\hline & $\mathrm{NH}$ & - & - \\
\hline \multirow{7}{*}{ Hpg3 } & 1 & - & 170.6 \\
\hline & 2 & 5.38 & 56.2 \\
\hline & 3 & - & 128.5 \\
\hline & 4 & 7.03 & 128.8 \\
\hline & 5 & 6.60 & 115.3 \\
\hline & 6 & - & 157.2 \\
\hline & $\mathrm{NH}$ & 8.57 & - \\
\hline \multirow[t]{7}{*}{ Tyr4 } & 1 & - & 171.0 \\
\hline & 2 & 4.32 & 55.1 \\
\hline & 3 & $2.77 ; 2.61$ & - \\
\hline & 5 & 6.82 & 130.6 \\
\hline & 6 & 6.52 & 115.3 \\
\hline & 7 & - & 156.2 \\
\hline & $\mathrm{NH}$ & 8.35 & - \\
\hline \multirow[t]{4}{*}{ Asn5 } & 1 & - & 170.6 \\
\hline & 2 & 4.57 & - \\
\hline & 3 & $2.22 ; 2.25$ & - \\
\hline & $\mathrm{NH}$ & 8.28 & - \\
\hline \multirow[t]{4}{*}{ Tyr6 } & 2 & 4.57 & 50.0 \\
\hline & 3 & $2.90 ; 2.60$ & - \\
\hline & 5 & 7.00 & 130.6 \\
\hline & 6 & 6.62 & 115.3 \\
\hline 3 & & & \\
\hline
\end{tabular}


Table S8. NMR assignments for 7 in $\left(\mathrm{CD}_{3}\right)_{2} \mathrm{SO}$ from $\mathrm{C}$ - to $\mathrm{N}$-terminus. The structure and number scheme for the compound is shown below the table.

\begin{tabular}{|c|c|c|c|}
\hline Residue & Label & $\delta H(p p m)$ & $\delta \mathrm{C}(\mathrm{ppm})$ \\
\hline \multirow[t]{4}{*}{ Pr } & 1 & 0.84 & - \\
\hline & 2 & $1.26 ; 1.46$ & - \\
\hline & 3 & $2.90 ; 3.12$ & - \\
\hline & $\mathrm{NH}$ & 7.45 & - \\
\hline \multirow[t]{5}{*}{ Tyr1 } & 2 & 4.50 & 49.6 \\
\hline & 3 & $2.58 / 2.80$ & - \\
\hline & 5 & 6.97 & 130.5 \\
\hline & 6 & 6.62 & 115.3 \\
\hline & $\mathrm{NH}$ & 8.06 & - \\
\hline \multirow[t]{6}{*}{ Tyr2 } & 2 & 4.25 & 57.1 \\
\hline & 3 & $3.02 ; 3.15$ & - \\
\hline & 5 & 7.13 & 140.5 \\
\hline & 8 & 6.67 & 115.3 \\
\hline & 9 & 7.03 & 128.5 \\
\hline & $\mathrm{NH}$ & 8.21 & - \\
\hline \multirow{4}{*}{ Hpg3 } & 2 & 5.42 & 56.9 \\
\hline & 4 & 7.22 & 129.8 \\
\hline & 5 & 6.77 & 115.6 \\
\hline & $\mathrm{NH}$ & 8.63 & - \\
\hline \multirow[t]{6}{*}{ Tyr4 } & 2 & 4.50 & 54.2 \\
\hline & 3 & $2.18 ; 2.51$ & - \\
\hline & 5 & 6.64 & 139.5 \\
\hline & 8 & 7.23 & - \\
\hline & 9 & 6.90 & 129.5 \\
\hline & NH & 8.12 & - \\
\hline \multirow[t]{3}{*}{ Asn5 } & 2 & 4.49 & 55.8 \\
\hline & 3 & $2.17 ; 2.42$ & - \\
\hline & $\mathrm{NH}$ & 7.99 & - \\
\hline \multirow[t]{5}{*}{ Tyr6 } & 2 & 4.46 & 53.8 \\
\hline & 3 & $2.57 ; 2.82$ & - \\
\hline & 5 & 6.95 & 130.6 \\
\hline & 6 & 6.58 & 115.1 \\
\hline & $\mathrm{NH}$ & 7.85 & - \\
\hline \multirow[t]{4}{*}{ NMeLeu7 } & 2 & 2.73 & - \\
\hline & 3 & 1.10 & - \\
\hline & 4 & 1.48 & - \\
\hline & 5 & $0.78 ; 0.73$ & - \\
\hline
\end{tabular}

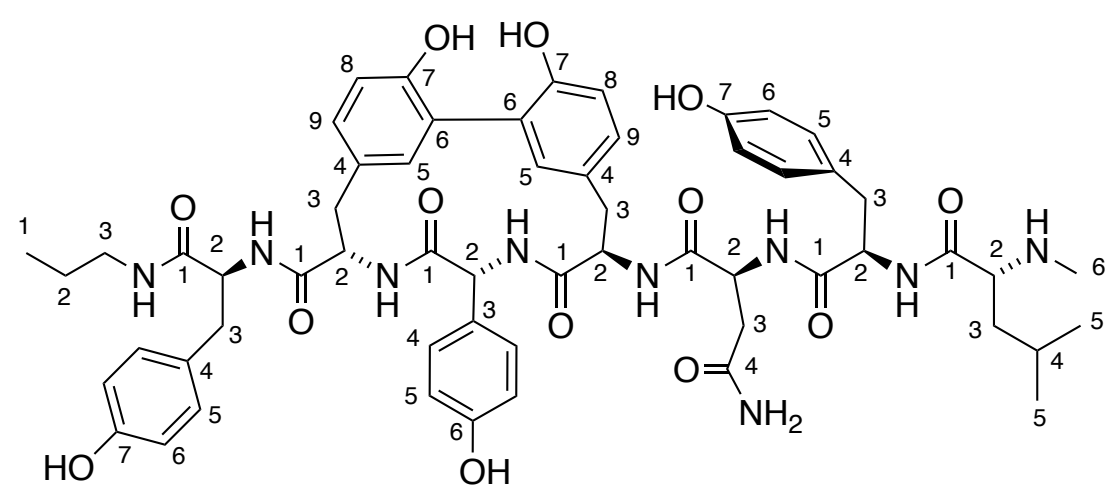


Table S9. NMR assignment for mycocyclosin in $\left(\mathrm{CD}_{3}\right)_{2} \mathrm{SO} .^{8}$

\begin{tabular}{cccc}
\hline \hline Residue & Label & $\boldsymbol{\delta H} \mathbf{( p p m )}$ & $\boldsymbol{\delta} \mathbf{C}(\mathbf{p p m})$ \\
\hline \hline Tyr & 2 & 4.32 & 55.6 \\
& 3 & $3.46 ; 2.64$ & 33.3 \\
& 5 & 6.57 & 141.4 \\
& 8 & 6.62 & 114.7 \\
& 9 & 6.84 & 129.8 \\
& $\mathrm{NH}$ & 7.99 & - \\
\hline
\end{tabular}

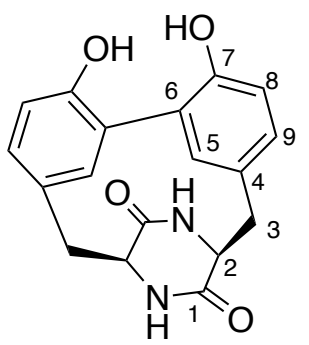


Table S10. NMR Assignment for arylomycin variant shown below in $\mathrm{CD}_{3} \mathrm{OH}$. Labelling of residues was assigned from $\mathrm{C}$ - to N-terminus. ${ }^{9}$

\begin{tabular}{cccc}
\hline \hline Residue & Label & $\boldsymbol{\delta} \mathbf{H}(\mathbf{p p m})$ & $\boldsymbol{\delta} \mathbf{C}(\mathbf{p p m})$ \\
\hline L-Tyr1 & 2 & 4.57 & 55.6 \\
& 3 & $3.38 ; 3.07$ & 35.4 \\
& 5 & 6.78 & 134.2 \\
& 8 & 6.74 & 116.7 \\
& 9 & 7.03 & 130.5 \\
\hline L-Ala2 & 2 & 4.81 & 50.3 \\
& 3 & 1.32 & 19.0 \\
\hline L-Hpg3 & 2 & 6.33 & 61.5 \\
& 4 & 6.99 & 136.3 \\
& 7 & 7.31 & 116.6 \\
& 8 & 7.21 & 130.4 \\
\hline
\end{tabular}

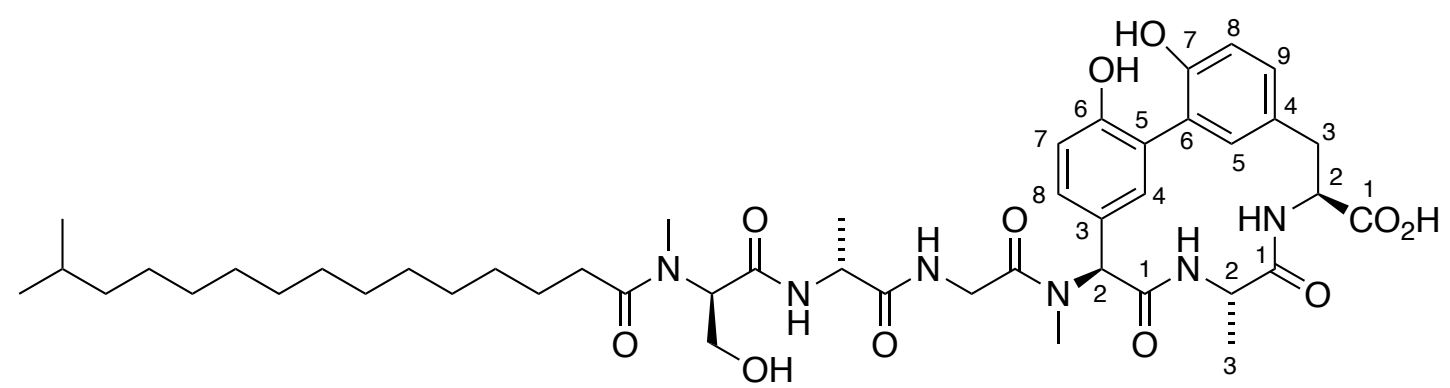


Table S11. HR-MS/MS data for 8 and its products upon reaction with OxyB, 9 and 10.

HR-MS/MS for substrate 8 (AA2 = L-homoTyr; AA4=D-Hpg)

\begin{tabular}{ccccl}
\hline $\begin{array}{c}\text { Charge } \\
\text { State }\end{array}$ & $\begin{array}{c}\text { Calculated } \\
\mathbf{m} / \mathbf{z}\end{array}$ & $\begin{array}{c}\text { Observed } \\
\mathbf{m} / \mathbf{z}\end{array}$ & $\boldsymbol{\Delta} \mathbf{p p m}$ & \multicolumn{1}{c}{ Sequence } \\
\hline $\mathbf{b}_{1}{ }^{+1}$ & 128.1075 & 128.1061 & 10.7 & MeLeu \\
$\mathbf{b}_{2}{ }^{+1}$ & 291.1709 & 291.172 & 3.9 & MeLeu-Tyr \\
$\mathbf{b}_{3}{ }^{+1}$ & 405.2138 & 405.2155 & 4.4 & MeLeu-Tyr-Asn \\
$\mathbf{b}^{+1}$ & 554.2615 & 554.2636 & 3.8 & MeLeu-Tyr-Asn-Hpg \\
$\mathbf{b}_{5}{ }^{+1}$ & 703.3092 & 703.3105 & 1.8 & MeLeu-Tyr-Asn-Hpg-Hpg \\
$\mathbf{b}_{6}{ }^{+1}$ & 880.3881 & 880.3884 & 0.4 & MeLeu-Tyr-Asn-Hpg-Hpg-HomoTyr \\
$\mathbf{b}_{7}{ }^{+1}$ & 1043.4515 & 1043.4508 & 0.6 & MeLeu-Tyr-Asn-Hpg-Hpg-HomoTyr-Tyr \\
\hline $\mathbf{y}_{2}{ }^{+1}$ & 223.1436 & 223.1449 & 5.8 & Tyr-propyl \\
$\mathbf{y}_{3}{ }^{+1}$ & 400.2225 & 400.2222 & 0.5 & HomoTyr-Tyr-propyl \\
$\mathbf{y}_{4}{ }^{+1}$ & 549.2702 & 549.2678 & 4.2 & Hpg-HomoTyr-Tyr-propyl \\
$\mathbf{y}_{5}{ }^{+1}$ & 698.3179 & 698.3157 & 3.1 & Hpg-Hpg-HomoTyr-Tyr-propyl \\
$\mathbf{y}_{6}{ }^{+1}$ & 812.3608 & 812.3611 & 0.4 & Asn-Hpg-Hpg-HomoTyr-Tyr-propyl \\
$\mathbf{y}_{7}{ }^{+1}$ & 975.4241 & 975.4265 & 2.4 & Tyr-Asn-Hpg-Hpg-HomoTyr-Tyr-propyl \\
\hline
\end{tabular}

HR-MS/MS for products 9 and 10 (AA2=L-homoTyr; $A A 4=D$-Hpg)

\begin{tabular}{|c|c|c|c|c|}
\hline $\begin{array}{l}\text { Charge } \\
\text { State }\end{array}$ & $\begin{array}{c}\text { Calculated } \\
\mathbf{m} / \mathbf{z}\end{array}$ & $\begin{array}{c}\text { Observed } \\
\mathbf{m} / \mathbf{z}\end{array}$ & $\Delta$ ppm & Sequence \\
\hline $\mathbf{b}_{2}^{+1}$ & 291.1709 & 291.1719 & 3.4 & MeLeu-Tyr \\
\hline $\mathbf{b}_{3}{ }^{+1}$ & 405.2138 & 405.2152 & 6 & MeLeu-Tyr-Asn \\
\hline $\mathbf{b}^{+1}$ & 878.3725 & 878.3745 & 2.2 & MeLeu-Tyr-Asn-Hpg $g_{m}-H p g-H o m o T y r_{m}$ \\
\hline $\mathbf{b}_{7}{ }^{+1}$ & 1041.4358 & 1041.4376 & 1.7 & MeLeu-Tyr-Asn-Hpg ${ }_{m}-H p g-H o m o T y r_{m}$ \\
\hline $\mathbf{y}_{2}{ }^{+1}$ & 223.1436 & 223.1446 & 4.8 & Tyr-propyl \\
\hline$y_{5}{ }^{+1}$ & 696.3022 & 696.3031 & 1.3 & $\mathrm{Hpg}_{\mathrm{m}}$-Hpg-HomoTyr $\mathrm{r}_{\mathrm{m}}$-Tyr-propyl \\
\hline $\mathbf{y}_{6}{ }^{+1}$ & 810.3452 & 810.3502 & 6.1 & Asn-Hpg ${ }_{m}$-Hpg-HomoTyr $r_{m}$-Tyr-propyl \\
\hline $\mathbf{y}_{7}^{+1}$ & 973.4085 & 973.4118 & 3.4 & Tyr-Asn-Hpg ${ }_{m}-H p g-H o m o T y r_{m}-$ Tyr-propyl \\
\hline
\end{tabular}


Table S12. HR-MS/MS data for starting material AA2 $=$ ortho $-{ }^{2} \mathrm{H}_{2}-\mathrm{L}-$ homoTyr and AA4 = DHpg and products upon reaction with OxyB (-2 Da product, 11; and -3 Da product, 12).

HR-MS/MS for starting material AA2 = ortho- ${ }^{2} \mathrm{H}_{2}-$ homo-L-Tyr and AA4 $=$ D-Hpg

\begin{tabular}{|c|c|c|c|c|}
\hline $\begin{array}{c}\text { Charge } \\
\text { State }\end{array}$ & $\begin{array}{c}\text { Calculated } \\
\mathbf{m} / \mathbf{z}\end{array}$ & $\begin{array}{c}\text { Observed } \\
\mathbf{m} / \mathbf{z}\end{array}$ & $\Delta$ ppm & Sequence \\
\hline $\mathbf{b}_{2}{ }^{+1}$ & 291.1709 & 291.168 & 9.8 & MeLeu-Tyr \\
\hline $\mathbf{b}_{3}{ }^{+1}$ & 405.2138 & 405.2181 & 10.7 & MeLeu-Tyr-Asn \\
\hline $\mathbf{b}_{4}{ }^{+1}$ & 554.2615 & 554.2656 & 7.4 & MeLeu-Tyr-Asn-Hpg \\
\hline $\mathbf{b}_{5}{ }^{+1}$ & 703.3092 & 703.3133 & 5.9 & MeLeu-Tyr-Asn-Hpg-Hpg \\
\hline $\mathbf{b}^{+1}$ & 882.4007 & 882.4 & 0.2 & MeLeu-Tyr-Asn-Hpg-Hpg- ${ }^{2} \mathrm{H}_{2} \mathrm{HomoTyr}$ \\
\hline $\mathbf{b}_{7}{ }^{+1}$ & 1045.4640 & 1045.4629 & 1.0 & MeLeu-Tyr-Asn-Hpg-Hpg- ${ }^{2} \mathrm{H}_{2}$ HomoTyr-Tyr \\
\hline $\mathrm{y}_{3}{ }^{+1}$ & 402.2351 & 402.2404 & 13.2 & ${ }^{2} \mathrm{H}_{2}$ HomoTyr-Tyr-propyl \\
\hline$y_{4}{ }^{+1}$ & 551.2828 & 551.2761 & 12.1 & $\mathrm{Hpg}^{2}{ }^{2} \mathrm{H}_{2}$ HomoTyr-Tyr-propyl \\
\hline $\mathbf{y}_{5}^{+1}$ & 700.3304 & 700.3374 & 10.1 & Hpg-Hpg- ${ }^{2} \mathrm{H}_{2}$ HomoTyr-Tyr-propyl \\
\hline$y_{6}{ }^{+1}$ & 814.3734 & 814.3833 & 12.1 & Asn-Hpg-Hpg- ${ }^{2} \mathrm{H}_{2}$ HomoTyr-Tyr-propyl \\
\hline $\mathbf{y}_{7}^{+1}$ & 977.4367 & 977.4377 & 1.1 & Tyr-Asn-Hpg-Hpg- ${ }^{2} \mathrm{H}_{2}$ HomoTyr-Tyr-propyl \\
\hline
\end{tabular}

HR-MS/MS for product 11 (-2Da product)

\begin{tabular}{|c|c|c|c|c|}
\hline $\begin{array}{c}\text { Charge } \\
\text { State }\end{array}$ & $\begin{array}{c}\text { Calculated } \\
\mathbf{m} / \mathbf{z}\end{array}$ & $\begin{array}{c}\text { Observed } \\
\mathbf{m} / \mathbf{z}\end{array}$ & $\Delta$ ppm & Sequence \\
\hline $\mathbf{b}_{2}{ }^{+1}$ & 291.1709 & 291.1681 & 9.3 & MeLeu-Tyr \\
\hline $\mathbf{b}_{3}{ }^{+1}$ & 405.2138 & 405.218 & 10.5 & MeLeu-Tyr-Asn \\
\hline $\mathrm{b}_{6}{ }^{+1}$ & 880.3850 & 880.3845 & 0.4 & MeLeu-Tyr-Asn-Hpg $-\mathrm{Hpg}_{-}{ }^{2} \mathrm{H}_{2} \mathrm{HomoTyr}_{\mathrm{m}}$ \\
\hline $\mathbf{b}_{7}{ }^{+1}$ & 1043.4484 & 1043.4446 & 3.6 & MeLeu-Tyr-Asn-Hpg $-\mathrm{Hpg}_{-}{ }^{2} \mathrm{H}_{2} \mathrm{HomoTyr}_{\mathrm{m}}$ \\
\hline $\mathrm{y}_{6}{ }^{+1}$ & 812.3577 & 812.3594 & 2.1 & Asn-Hpg ${ }_{m}-\mathrm{Hpg}_{-}{ }^{2} \mathrm{H}_{2} \mathrm{HomoTyr}_{\mathrm{m}}$-Tyr-propyl \\
\hline $\mathbf{y}_{7}^{+1}$ & 975.4211 & 975.4296 & 0.4 & 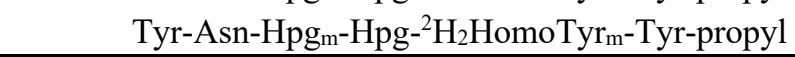 \\
\hline
\end{tabular}

HR-MS/MS for product 12 (-3Da product)

\begin{tabular}{|c|c|c|c|c|}
\hline $\begin{array}{c}\text { Charge } \\
\text { State } \\
\end{array}$ & $\begin{array}{c}\text { Calculated } \\
\mathbf{m} / \mathbf{z}\end{array}$ & $\begin{array}{c}\text { Observed } \\
\mathbf{m} / \mathbf{z} \\
\end{array}$ & $\Delta$ ppm & Sequence \\
\hline $\mathbf{b}_{2}+1$ & 291.1709 & 291.1705 & 1.0 & MeLeu-Tyr \\
\hline $\mathbf{b}_{3}{ }^{+1}$ & 405.2138 & 405.216 & 5.5 & MeLeu-Tyr-Asn \\
\hline $\mathrm{b}_{6}{ }^{+1}$ & 879.3788 & 879.3772 & 1.7 & MeLeu-Tyr-Asn-Hpg $-\mathrm{Hpg}^{2}{ }^{2} \mathrm{H}_{2} \mathrm{HomoTyr}_{\mathrm{m}}$ \\
\hline $\mathbf{y}_{7}^{+1}$ & 974.4148 & 974.4166 & 1.9 & Tyr-Asn-Hpg ${ }_{m}-H_{p g}-{ }^{2} \mathrm{H}_{2} \mathrm{HomoTyr}_{\mathrm{m}}$-Tyr-propyl \\
\hline
\end{tabular}


Table S13. HR-MS/MS data for starting material AA2 = L-homoTyr and AA4 = ortho- ${ }^{2} \mathrm{H}_{2}-\mathrm{D}-$ Hpg and products upon reaction with OxyB (-2 Da product, 13; and -3 Da product, 14).

$H R-M S / M S$ for starting material AA2 = homo-L-Tyr and AA4 =ortho- ${ }^{2} H_{2}-D-H p g$

\begin{tabular}{|c|c|c|c|c|}
\hline $\begin{array}{l}\text { Charge } \\
\text { State }\end{array}$ & $\begin{array}{c}\text { Calculated } \\
\mathbf{m} / \mathbf{z}\end{array}$ & $\begin{array}{c}\text { Observed } \\
\mathbf{m} / \mathbf{z}\end{array}$ & $\Delta \mathrm{ppm}$ & Sequence \\
\hline $\mathbf{b}_{2}{ }^{+1}$ & 291.1709 & 291.1669 & 13.5 & MeLeu-Tyr \\
\hline$b_{3}{ }^{+1}$ & 405.2138 & 405.2154 & 3.9 & MeLeu-Tyr-Asn \\
\hline $\mathbf{b}_{4}{ }^{+1}$ & 556.274 & 556.2784 & 7.9 & MeLeu-Tyr-Asn-Hpg \\
\hline $\mathbf{b}_{5}^{+1}$ & 705.3216 & 705.3216 & 0.1 & MeLeu-Tyr-Asn-Hpg- ${ }^{2} \mathrm{H}_{2} \mathrm{Hpg}$ \\
\hline$b_{6}{ }^{+1}$ & 882.4007 & 882.3984 & 2.5 & MeLeu-Tyr-Asn-Hpg- ${ }^{2} \mathrm{H}_{2} \mathrm{Hpg}-\mathrm{HomoTyr}$ \\
\hline $\mathbf{b}_{7}{ }^{+1}$ & 1045.464 & 1045.4598 & 4.0 & MeLeu-Tyr-Asn-Hpg- ${ }^{2} \mathrm{H}_{2} \mathrm{Hpg}$-HomoTyr-Tyr \\
\hline $\mathrm{y}_{3}{ }^{+1}$ & 400.2225 & 400.2131 & 23.3 & HomoTyr-Tyr-propyl \\
\hline $\mathbf{y}_{4}^{+1}$ & 549.2702 & 549.268 & 3.9 & Hpg-HomoTyr-Tyr-propyl \\
\hline $\mathbf{y}_{5}{ }^{+1}$ & 700.3304 & 700.3256 & 6.7 & ${ }^{2} \mathrm{H}_{2} \mathrm{Hpg}$-Hpg-HomoTyr-Tyr-propyl \\
\hline $\mathbf{y}_{6}{ }^{+1}$ & 814.3732 & 814.3657 & 9.4 & Asn- ${ }^{2} \mathrm{H}_{2} \mathrm{Hpg}$-Hpg-HomoTyr-Tyr-propyl \\
\hline$y_{7}{ }^{+1}$ & 977.4367 & 977.4254 & 11.4 & Tyr-Asn- ${ }^{2} \mathrm{H}_{2} \mathrm{Hpg}$-Hpg-HomoTyr-Tyr-propyl \\
\hline
\end{tabular}

HR-MS/MS for product 13 (-2Da product)

\begin{tabular}{|c|c|c|c|c|}
\hline $\begin{array}{c}\text { Charge } \\
\text { State } \\
\end{array}$ & $\begin{array}{c}\text { Calculated } \\
\mathbf{m} / \mathbf{z}\end{array}$ & $\begin{array}{c}\text { Observed } \\
\mathbf{m} / \mathbf{z} \\
\end{array}$ & $\Delta \mathbf{p p m}$ & Sequence \\
\hline $\mathbf{b}_{3}{ }^{+1}$ & 405.2138 & 405.2126 & 2.8 & MeLeu-Tyr-Asn \\
\hline$b_{6}{ }^{+1}$ & 880.385 & 880.3772 & 8.8 & MeLeu-Tyr-Asn- ${ }^{2} \mathrm{H}_{2} \mathrm{Hpg}_{\mathrm{m}}-\mathrm{Hpg}$-HomoTyr $\mathrm{r}_{\mathrm{m}}$ \\
\hline $\mathbf{b}_{7}^{+1}$ & 1043.4484 & 1043.439 & 9.0 & MeLeu-Tyr-Asn- ${ }^{2} \mathrm{H}_{2} \mathrm{Hpg}_{\mathrm{m}}-\mathrm{Hpg}$-HomoTyr $\mathrm{r}_{\mathrm{m}}$ \\
\hline$y_{6}{ }^{+1}$ & 812.3577 & 812.3626 & 6.1 & $\mathrm{Asn}^{-}{ }^{2} \mathrm{H}_{2} \mathrm{Hpg}_{\mathrm{m}}-\mathrm{Hpg}-\mathrm{HomoTyr}$-Tyr-propyl \\
\hline $\mathbf{y}_{7}^{+1}$ & 975.4211 & 975.411 & 10.2 & Tyr-Asn- ${ }^{2} \mathrm{H}_{2} \mathrm{Hpg}_{\mathrm{m}}-\mathrm{Hpg}$-HomoTyr $\mathrm{r}_{\mathrm{m}}$-Tyr-propyl \\
\hline
\end{tabular}

HR-MS/MS for product 14 (-3 Da product)

\begin{tabular}{|c|c|c|c|c|}
\hline $\begin{array}{l}\text { Charge } \\
\text { State }\end{array}$ & $\begin{array}{c}\text { Calculated } \\
\mathrm{m} / \mathrm{z}\end{array}$ & $\begin{array}{c}\text { Observed } \\
\mathbf{m} / \mathbf{z}\end{array}$ & $\Delta p p m$ & Sequence \\
\hline $\mathbf{b}_{2}^{+1}$ & 291.1709 & 291.1652 & 19.3 & MeLeu-Tyr \\
\hline $\mathbf{b}_{3}^{+1}$ & 405.2138 & 405.2137 & 0.2 & MeLeu-Tyr-Asn \\
\hline $\mathbf{b}_{6}{ }^{+1}$ & 879.3788 & 879.3812 & 2.7 & MeLeu-Tyr-Asn- ${ }^{2} \mathrm{H}_{2} \mathrm{Hpg}_{\mathrm{m}}-\mathrm{Hpg}$-HomoTyrm \\
\hline $\mathbf{b}_{7}^{+1}$ & 1042.4421 & 1042.4326 & 9.0 & MeLeu-Tyr-Asn- ${ }^{2} \mathrm{H}_{2} \mathrm{Hpg}_{\mathrm{m}}-\mathrm{Hpg}-\mathrm{HomoTyr}_{\mathrm{m}}$ \\
\hline $\mathrm{y}^{+1}$ & 811.3514 & 811.3393 & 14.8 & Asn- ${ }^{2} \mathrm{H}_{2} \mathrm{Hpg}_{\mathrm{m}}-\mathrm{Hpg}$-HomoTyr $\mathrm{m}$-Tyr-propyl \\
\hline $\mathbf{y}_{7}^{+1}$ & 974.4148 & 974.4125 & 2.3 & Tyr-Asn- ${ }^{2} \mathrm{H}_{2} \mathrm{Hpg}$ m-Hpg-HomoTyr ${ }_{\mathrm{m}}$-Tyr-propyl \\
\hline
\end{tabular}


Table S14. HR-MS/MS data for starting material 15 (AA2 = L-Tyr, AA4 = L-Hpg) and its product upon reaction with $\mathrm{OxyB}, 16$.

HR-MS/MS for starting material 15 (AA2 = L-Tyr;AA4 =L-Hpg)

\begin{tabular}{ccccl}
\hline $\begin{array}{c}\text { Charge } \\
\text { State }\end{array}$ & $\begin{array}{c}\text { Calculated } \\
\mathbf{m} / \mathbf{z}\end{array}$ & $\begin{array}{c}\text { Observed } \\
\mathbf{m} / \mathbf{z}\end{array}$ & \multicolumn{1}{|c|}{ (ppm } & \multicolumn{2}{c}{ Sequence } \\
\hline $\mathbf{b}_{2}{ }^{+1}$ & 291.1709 & 291.1756 & 16.3 & MeLeu-Tyr \\
$\mathbf{b}_{3}{ }^{+1}$ & 405.2138 & 405.2199 & 15.2 & MeLeu-Tyr-Asn \\
$\mathbf{b}_{4}{ }^{+1}$ & 554.2615 & 554.2701 & 15.5 & MeLeu-Tyr-Asn-(L)Hpg \\
$\mathbf{b}_{5}{ }^{+1}$ & 703.3092 & 703.3198 & 15.1 & MeLeu-Tyr-Asn-(L)Hpg-Hpg \\
$\mathbf{b}_{6}{ }^{+1}$ & 866.3725 & 866.3827 & 11.8 & MeLeu-Tyr-Asn-(L)Hpg-Hpg-(L)Tyr \\
$\mathbf{b}_{7}{ }^{+1}$ & 1029.4358 & 1029.4463 & 10.2 & MeLeu-Tyr-Asn-(L)Hpg-Hpg-(L)Tyr-Tyr \\
$\mathbf{y}_{3}{ }^{+1}$ & 386.2069 & 386.2137 & 17.6 & (L)Tyr-Tyr-propyl \\
$\mathbf{y}_{4}{ }^{+1}$ & 535.2546 & 535.2647 & 18.9 & Hpg-(L)Tyr-Tyr-propyl \\
$\mathbf{y}_{5}{ }^{+1}$ & 684.3022 & 684.3126 & 15.3 & (L)Hpg-Hpg-(L)Tyr-Tyr-propyl \\
$\mathbf{y}_{6}{ }^{+1}$ & 798.3452 & 798.35 & 6.0 & Asn-(L)Hpg-Hpg-(L)Tyr-Tyr-propyl \\
$\mathbf{y}_{7}{ }^{+\mathbf{1}}$ & 961.4085 & 961.4222 & 14.2 & Tyr-Asn-(L)Hpg-Hpg-(L)Tyr-Tyr-propyl \\
\hline
\end{tabular}

HR-MS/MS for starting material 16 (AA2 = L-Tyr; AA4 =L-Hpg)

\begin{tabular}{|c|c|c|c|c|}
\hline $\begin{array}{c}\text { Charge } \\
\text { State } \\
\end{array}$ & $\begin{array}{c}\text { Calculated } \\
\mathbf{m} / \mathbf{z}\end{array}$ & $\begin{array}{c}\text { Observed } \\
\mathbf{m} / \mathbf{z} \\
\end{array}$ & $\Delta$ ppm & Sequence \\
\hline $\mathbf{b}_{2}{ }^{+1}$ & 291.1709 & 291.1751 & 14.5 & MeLeu-Tyr \\
\hline $\mathbf{b}_{3}{ }^{+1}$ & 405.2138 & 405.2205 & 16.6 & MeLeu-Tyr-Asn \\
\hline $\mathbf{b}_{4}^{+1}$ & 554.2615 & 554.2632 & 1.3 & MeLeu-Tyr-Asn-(L)Hpg \\
\hline $\mathbf{b}_{6}{ }^{+1}$ & 864.3491 & 864.362 & 6.1 & MeLeu-Tyr-Asn-(L)Hpg-Hpg ${ }_{m}-(\mathrm{L}) \mathrm{Tyr}_{\mathrm{m}}$ \\
\hline $\mathbf{b}_{7}{ }^{+1}$ & 1027.4202 & 1027.4229 & 2.7 & MeLeu-Tyr-Asn-(L)Hpg-Hpg ${ }_{m}-(\mathrm{L}) \mathrm{Tyr}_{\mathrm{m}}-\mathrm{Tyr}$ \\
\hline $\mathbf{y}_{2}+1$ & 223.1472 & 223.1468 & 16.2 & Tyr-propyl \\
\hline $\mathbf{y}^{+1}$ & 533.2389 & 533.2445 & 10.5 & Hpg $_{m}-(\mathrm{L}) \mathrm{Tyr}_{\mathrm{m}}$-Tyr-propyl \\
\hline $\mathbf{y}_{5}^{+1}$ & 682.2866 & 682.2964 & 14.4 & (L)Hpg-Hpg $-(\mathrm{L}) \mathrm{Tyr}_{\mathrm{m}}-\mathrm{Tyr}-$ propyl \\
\hline $\mathrm{y}_{6}{ }^{+1}$ & 796.3295 & 796.3391 & 12.1 & Asn-(L)Hpg-Hpg $-(\mathrm{L}) \mathrm{Tyr}_{\mathrm{m}}$-Tyr-propyl \\
\hline $\mathbf{y}_{7}^{+1}$ & 959.3928 & 959.4035 & 11.1 & Tyr-Asn-(L)Hpg-Hpg \\
\hline
\end{tabular}


Table S15. NMR assignments for $\mathbf{1 5}$ in $\left(\mathrm{CD}_{3}\right)_{2} \mathrm{SO}$ from $\mathrm{C}$ - to N-terminus. The structure and number scheme for the compound is shown below the table.

\begin{tabular}{|c|c|c|c|}
\hline Residue & Label & $\delta \mathrm{\delta H}(\mathrm{ppm})$ & $\delta \mathrm{C}(\mathrm{ppm})$ \\
\hline \multirow[t]{4}{*}{$\mathrm{Pr}$} & $\overline{11}$ & 0.76 & $\begin{array}{lll}11.7 \\
\end{array}$ \\
\hline & 2 & 1.32 & 22.7 \\
\hline & 3 & $2.93 ; 3.00$ & 40.7 \\
\hline & $\mathrm{NH}$ & 7.76 & - \\
\hline \multirow[t]{6}{*}{ Tyr1 } & 1 & - & 171.1 \\
\hline & 2 & 4.34 & 55.0 \\
\hline & 3 & $2.75 ; 2.84$ & 37.5 \\
\hline & 5 & 7.02 & 130.6 \\
\hline & 6 & 6.64 & 115.0 \\
\hline & $\mathrm{NH}$ & 8.19 & - \\
\hline \multirow[t]{6}{*}{ Tyr2 } & 1 & - & 171.1 \\
\hline & 2 & 4.34 & 55.0 \\
\hline & 3 & $2.55 ; 2.80$ & 37.4 \\
\hline & 5 & 6.84 & 130.6 \\
\hline & 6 & 6.51 & 115.1 \\
\hline & $\mathrm{NH}$ & 8.38 & - \\
\hline \multirow[t]{5}{*}{ Hpg3 } & 1 & - & 170.1 \\
\hline & 2 & 5.35 & 55.8 \\
\hline & 4 & 6.73 & 128.1 \\
\hline & 5 & 6.48 & 115.0 \\
\hline & $\mathrm{NH}$ & 8.64 & - \\
\hline \multirow[t]{5}{*}{ Hpg4 } & 1 & - & 170.0 \\
\hline & 2 & 5.50 & 55.7 \\
\hline & 4 & 7.15 & 128.7 \\
\hline & 5 & 6.63 & 115.3 \\
\hline & NH & 8.25 & - \\
\hline \multirow[t]{4}{*}{ Asn5 } & 1 & - & 170.3 \\
\hline & 2 & 4.70 & - \\
\hline & 3 & $2.37 ; 2.55$ & 37.4 \\
\hline & 4 & - & 172.0 \\
\hline \multirow[t]{5}{*}{ Tyr6 } & 1 & - & 171.7 \\
\hline & 2 & 4.61 & 53.7 \\
\hline & 3 & $2.62 ; 2.91$ & 38.0 \\
\hline & 5 & 6.99 & 130.6 \\
\hline & 6 & 6.60 & 115.1 \\
\hline
\end{tabular}

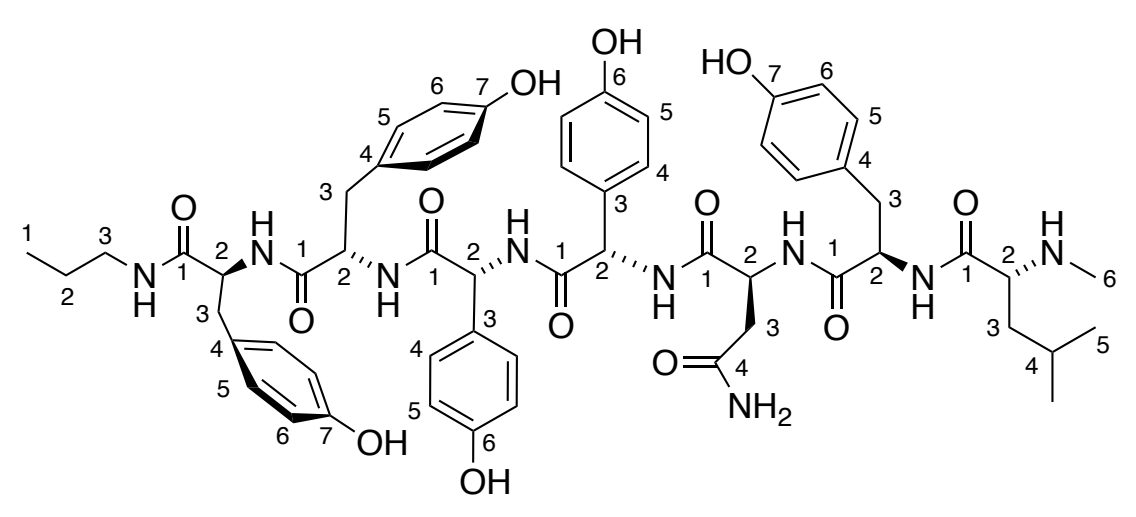


Table S16. NMR assignments for $\mathbf{1 6}$ in $\left(\mathrm{CD}_{3}\right)_{2} \mathrm{SO}$ from $\mathrm{C}$ - to N-terminus. The structure and number scheme for the compound is shown below the table.

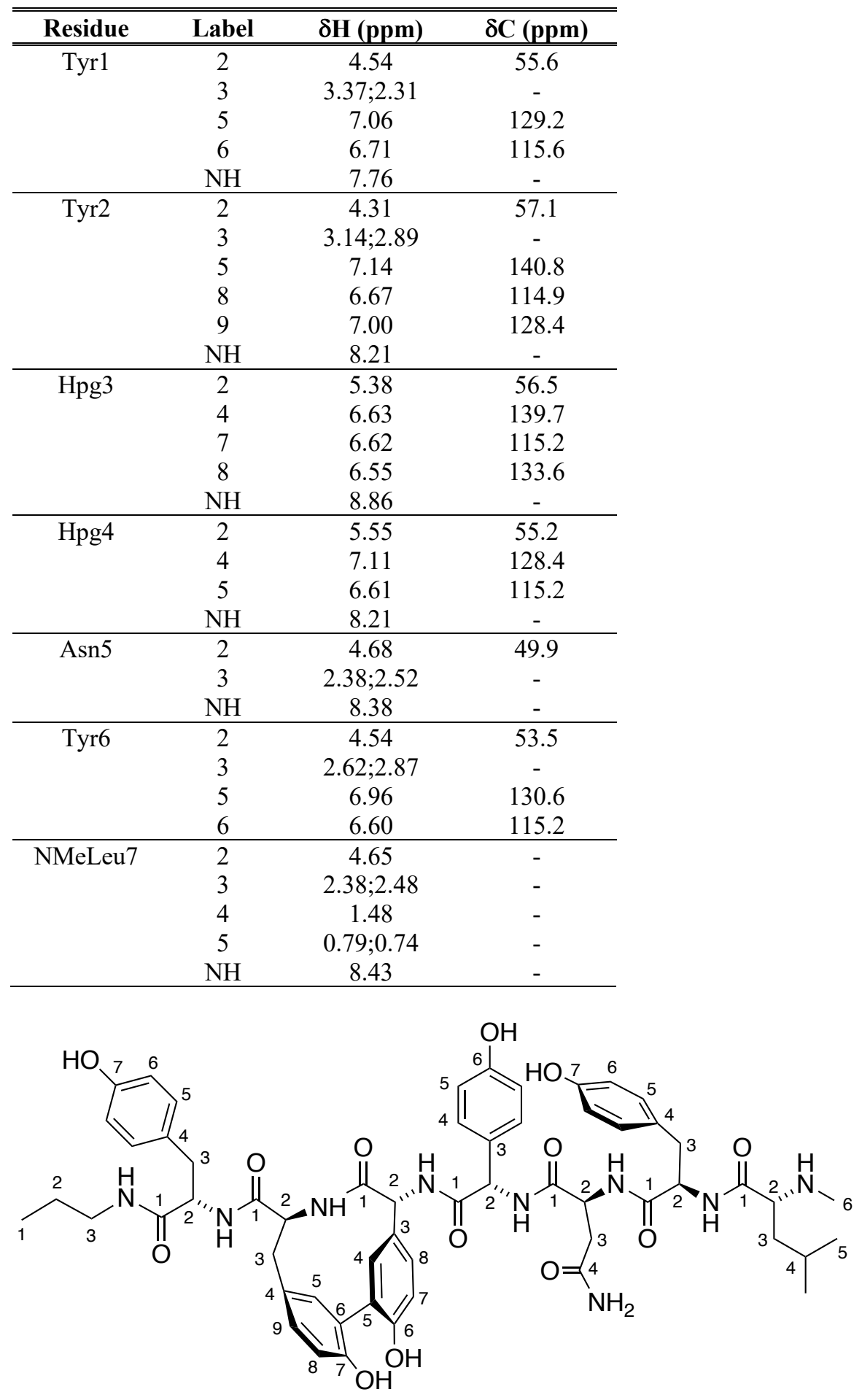


Table S17. HR-MS/MS data for starting material 17 (AA2 = D-Tyr, AA4 = D-Hpg) and its product upon reaction with $\mathrm{OxyB}, \mathbf{1 8}$.

HR-MS/MS for starting material $17(A A 2=D-T y r, A A 4=D-H p g)$

\begin{tabular}{|c|c|c|c|c|}
\hline $\begin{array}{l}\text { Charge } \\
\text { State }\end{array}$ & $\begin{array}{c}\text { Calculated } \\
\mathrm{m} / \mathrm{z}\end{array}$ & $\begin{array}{c}\text { Observed } \\
\mathbf{m} / \mathbf{z}\end{array}$ & $\Delta$ ppm & Sequence \\
\hline $\mathbf{b}_{1}{ }^{+1}$ & 128.1075 & 128.1097 & 17.0 & MeLeu \\
\hline $\mathbf{b}_{2}{ }^{+1}$ & 291.1709 & 291.1737 & 9.7 & MeLeu-Tyr \\
\hline $\mathbf{b}_{3}{ }^{+1}$ & 405.2138 & 405.2178 & 9.8 & MeLeu-Tyr-Asn \\
\hline $\mathbf{b}^{+1}$ & 554.2615 & 554.2664 & 8.9 & MeLeu-Tyr-Asn-(D)Hpg \\
\hline $\mathbf{b s}^{+1}$ & 703.3092 & 703.3138 & 6.5 & MeLeu-Tyr-Asn-(D)Hpg-Hpg \\
\hline $\mathbf{b}_{6}{ }^{+1}$ & 866.3725 & 866.3781 & 6.5 & MeLeu-Tyr-Asn-(D)Hpg-Hpg-(D)Tyr \\
\hline $\mathbf{b}_{7}^{+1}$ & 1029.4358 & 1029.4406 & 4.6 & MeLeu-Tyr-Asn-(D)Hpg-Hpg-(D)Tyr-Tyr \\
\hline $\mathrm{y}_{2}{ }^{+1}$ & 223.1426 & 223.1458 & 14.6 & Tyr-propyl \\
\hline $\mathbf{y}^{+1}$ & 386.2069 & 386.21306 & 15.9 & (D)Tyr-Tyr-propyl \\
\hline $\mathbf{y}_{4}^{+1}$ & 535.2546 & 535.2634 & 16.4 & Hpg-(D)Tyr-Tyr-propyl \\
\hline $\mathbf{y s}^{+1}$ & 684.3022 & 684.3067 & 6.6 & (D)Hpg-Hpg-(D)Tyr-Tyr-propyl \\
\hline $\mathbf{y}_{7}^{+1}$ & 961.4085 & 961.4152 & 7.0 & Tyr-Asn-(D)Hpg-Hpg-(D)Tyr-Tyr-propyl \\
\hline
\end{tabular}

HR-MS/MS for product $18(A A 2=D-T y r, A A 4=D-H p g)$

\begin{tabular}{|c|c|c|c|c|}
\hline $\begin{array}{c}\text { Charge } \\
\text { State }\end{array}$ & $\begin{array}{c}\text { Calculated } \\
\mathrm{m} / \mathrm{z}\end{array}$ & $\begin{array}{c}\text { Observed } \\
\mathbf{m} / \mathbf{z}\end{array}$ & $\Delta \mathrm{ppm}$ & Sequence \\
\hline $\mathbf{b}_{2}{ }^{+1}$ & 291.1709 & 291.174 & 10.7 & MeLeu-Tyr \\
\hline $\mathbf{b}_{3}{ }^{+1}$ & 405.2138 & 405.2182 & 10.8 & MeLeu-Tyr-Asn \\
\hline $\mathbf{b}_{6}^{+1}$ & 864.3491 & 864.3568 & 8.8 & MeLeu-Tyr-Asn-(D)Hpg m-Hpg-(D)Tyr $_{m}$ \\
\hline $\mathbf{b}_{7}^{+1}$ & 1027.4202 & 1027.4109 & 9 & MeLeu-Tyr-Asn-(D)Hpg ${ }_{m}-H p g-(D) T_{y r}-T y r$ \\
\hline $\mathbf{y}_{2}{ }^{+1}$ & 223.1436 & 223.1455 & 8.8 & Tyr-propyl \\
\hline $\mathbf{y}_{5}^{+1}$ & 682.2866 & 682.2931 & 9.6 & (D)Hpg $g_{m}-H p g-(D) T_{y r}$-Tyr-propyl \\
\hline$y_{6}{ }^{+1}$ & 796.3295 & 796.338 & 10.7 & Asn-(D)Hpg $\mathrm{H}_{\mathrm{m}}-\mathrm{Hpg}$-(D)Tyrm-Tyr-propyl \\
\hline $\mathbf{y}_{7}^{+1}$ & 959.3928 & 959.4027 & 10.3 & 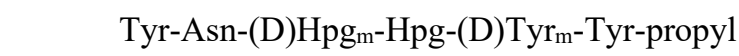 \\
\hline
\end{tabular}


Table S18. HR-MS/MS data for starting material AA2 $=$ D-Tyr and AA4 $=$ ortho ${ }^{2} \mathrm{H}_{2}-\mathrm{D}-\mathrm{Hpg}$ and -3 Da product upon reaction with OxyB (19).

HR-MS/MS for starting material AA2 = D-Tyr and AA4 $=$ ortho- ${ }^{2} \mathrm{H}_{2}-\mathrm{D}-\mathrm{Hpg}$

\begin{tabular}{|c|c|c|c|c|}
\hline $\begin{array}{c}\text { Charge } \\
\text { State }\end{array}$ & $\begin{array}{c}\text { Calculated } \\
\mathbf{m} / \mathbf{z}\end{array}$ & $\begin{array}{c}\text { Observed } \\
\mathbf{m} / \mathbf{z}\end{array}$ & $\Delta$ ppm & Sequence \\
\hline$\overline{b_{2}{ }^{+1}}$ & 291.1709 & 291.1711 & 0.9 & MeLeu-Tyr \\
\hline $\mathbf{b}_{3}{ }^{+1}$ & 405.2138 & 405.2162 & 6.0 & MeLeu-Tyr-Asn \\
\hline $\mathbf{b}^{+1}$ & 556.274 & 556.2765 & 4.6 & MeLeu-Tyr-Asn-(D) ${ }^{2} \mathrm{H}_{2} \mathrm{Hpg}$ \\
\hline $\mathbf{b}_{5}{ }^{+1}$ & 705.3217 & 705.3238 & 2.9 & MeLeu-Tyr-Asn-(D) ${ }^{2} \mathrm{H}_{2} \mathrm{Hpg}-\mathrm{Hpg}$ \\
\hline $\mathbf{b}_{6}^{+1}$ & 868.3879 & 868.385 & 3.3 & MeLeu-Tyr-Asn-(D) ${ }^{2} \mathrm{H}_{2}$ Hpg-Hpg-(D)Tyr \\
\hline $\mathbf{b}_{7}^{+1}$ & 1031.4484 & 1031.4515 & 3.0 & MeLeu-Tyr-Asn-(D) ${ }^{2} \mathrm{H}_{2} \mathrm{Hpg}$-Hpg-(D)Tyr-Tyr \\
\hline $\mathrm{y}_{2}{ }^{+1}$ & 223.1426 & 223.1418 & 7.7 & $\begin{array}{lll} & \text { Tyr-propyl }\end{array}$ \\
\hline $\mathbf{y}_{3}{ }^{+1}$ & 386.2069 & 386.2103 & 8.8 & (D)Tyr-Tyr-propyl \\
\hline $\mathbf{y}^{+1}$ & 535.2546 & 535.2569 & 4.3 & Hpg-(D)Tyr-Tyr-propyl \\
\hline $\mathbf{y}_{5}^{+1}$ & 686.3148 & 686.3152 & 0.6 & (D) ${ }^{2} \mathrm{H}_{2} \mathrm{Hpg}$-Hpg-(D)Tyr-Tyr-propyl \\
\hline $\mathrm{y}_{6}{ }^{+1}$ & 800.3577 & 800.3598 & 2.6 & Asn-(D) ${ }^{2} \mathrm{H}_{2} \mathrm{Hpg}$-Hpg-(D)Tyr-Tyr-propyl \\
\hline $\mathbf{y}_{7}^{+1}$ & 963.4211 & 963.4242 & 3.2 & Tyr-Asn-(D) ${ }^{2} \mathrm{H}_{2} \mathrm{Hpg}-\mathrm{Hpg}-(\mathrm{D}) \mathrm{Tyr}-\mathrm{Tyr}-$ propyl \\
\hline
\end{tabular}

HR-MS/MS for product 19

\begin{tabular}{|c|c|c|c|c|}
\hline $\begin{array}{c}\text { Charge } \\
\text { State }\end{array}$ & $\begin{array}{c}\text { Calculated } \\
\mathbf{m} / \mathbf{z}\end{array}$ & $\begin{array}{c}\text { Observed } \\
\mathbf{m} / \mathbf{z}\end{array}$ & $\Delta$ ppm & Sequence \\
\hline $\mathbf{b}_{2}^{+1}$ & 291.1709 & 291.1702 & 2.2 & MeLeu-Tyr \\
\hline $\mathbf{b}_{3}{ }^{+1}$ & 405.2138 & 405.2151 & 3.4 & MeLeu-Tyr-Asn \\
\hline $\mathbf{b}_{6}{ }^{+1}$ & 865.3631 & 865.368 & 5.6 & MeLeu-Tyr-Asn-(D) ${ }^{2} \mathrm{H}_{2} \mathrm{Hpg}_{\mathrm{m}}-\mathrm{Hpg}-(\mathrm{D}) \mathrm{Tyr}_{\mathrm{m}}$ \\
\hline $\mathbf{b}_{7}^{+1}$ & 1028.4264 & 1028.429 & 2.5 & MeLeu-Tyr-Asn-(D) ${ }^{2} \mathrm{H}_{2} \mathrm{Hpg}_{\mathrm{m}}-\mathrm{Hpg}$-(D)Tyr ${ }_{\mathrm{m}}-\mathrm{Tyr}$ \\
\hline $\mathrm{y}_{2}^{+1}$ & 223.1436 & 223.1411 & 11.1 & Tyr-propyl \\
\hline $\mathbf{y}_{5}^{+1}$ & 683.2929 & 683.2944 & 2.2 & (D) ${ }^{2} \mathrm{H}_{2} \mathrm{Hpg}_{\mathrm{m}}-\mathrm{Hpg}$-(D)Tyr $\mathrm{m}$-Tyr-propyl \\
\hline $\mathbf{y}_{6}{ }^{+1}$ & 797.3358 & 797.3409 & 6.4 & Asn-(D) ${ }^{2} \mathrm{H}_{2} \mathrm{Hpg}_{\mathrm{m}}-\mathrm{Hpg}-(\mathrm{D}) \mathrm{Tyr}_{\mathrm{m}}$-Tyr-propyl \\
\hline $\mathbf{y}_{7}^{+1}$ & 960.3991 & 960.4027 & 3.8 & Tyr-Asn-(D) ${ }^{2} \mathrm{H}_{2} \mathrm{Hpg}_{\mathrm{m}}-\mathrm{Hpg}$-(D)Tyr ${ }_{\mathrm{m}}$-Tyr-propyl \\
\hline
\end{tabular}


Table S19. HR-MS/MS data for starting material 20 (AA2 = D-Tyr, AA4 = L-Hpg) and products 21, 22.

HR-MS/MS for starting material 20 (AA2 =D-Tyr, AA4 =L-Hpg)

\begin{tabular}{|c|c|c|c|c|}
\hline $\begin{array}{c}\text { Charge } \\
\text { State } \\
\end{array}$ & $\begin{array}{c}\text { Calculated } \\
\mathrm{m} / \mathbf{z} \\
\end{array}$ & $\begin{array}{c}\text { Observed } \\
\mathbf{m} / \mathbf{z} \\
\end{array}$ & $\Delta p p m$ & Sequence \\
\hline $\mathbf{b}_{1}^{+1}$ & 128.1075 & 128.1079 & 3.6 & MeLeu \\
\hline $\mathrm{b}_{2}+1$ & 291.1709 & 291.1752 & 14.9 & MeLeu-Tyr \\
\hline $\mathbf{b}_{3}{ }^{+1}$ & 405.2138 & 405.2205 & 16.5 & MeLeu-Tyr-Asn \\
\hline $\mathbf{b}_{4}^{+1}$ & 554.2615 & 554.2699 & 15.5 & MeLeu-Tyr-Asn-(L)Hpg \\
\hline$b_{5}+1$ & 703.3092 & 703.3199 & 15.2 & MeLeu-Tyr-Asn-(L)Hpg-Hpg \\
\hline $\mathbf{b}_{6}{ }^{+1}$ & 866.3725 & 866.3818 & 10.8 & MeLeu-Tyr-Asn-(L)Hpg-Hpg-(D)Tyr \\
\hline $\mathbf{b}_{7}+1$ & 1029.4358 & 1029.4459 & 9.8 & MeLeu-Tyr-Asn-(L)Hpg-Hpg-(D)Tyr-Tyr \\
\hline$y_{3}+1$ & 386.2069 & 386.2122 & 13.8 & (D)Tyr-Tyr-propyl \\
\hline $\mathrm{y}_{4}^{+1}$ & 535.2546 & 535.2633 & 16.4 & Hpg-(D)Tyr-Tyr-propyl \\
\hline $\mathbf{y 5}^{+1}$ & 684.3022 & 684.3104 & 12.0 & (L)Hpg-Hpg-(D)Tyr-Tyr-propyl \\
\hline$y_{6}+1$ & 798.3452 & 798.3561 & 13.7 & Asn-(L)Hpg-Hpg-(D)Tyr-Tyr-propyl \\
\hline $\mathbf{y}_{7}^{+1}$ & 961.4085 & 961.4276 & 19.9 & Tyr-Asn-(L)Hpg-Hpg-(D)Tyr-Tyr-propyl \\
\hline
\end{tabular}

$H R-M S / M S$ for products 21,22 (AA2 = D-Tyr, AA4 =L-Hpg)

\begin{tabular}{|c|c|c|c|c|}
\hline $\begin{array}{c}\text { Charge } \\
\text { State }\end{array}$ & $\begin{array}{c}\text { Calculated } \\
\mathbf{m} / \mathbf{z}\end{array}$ & $\begin{array}{c}\text { Observed } \\
\mathbf{m} / \mathbf{z}\end{array}$ & $\Delta$ ppm & Sequence \\
\hline $\mathbf{b}_{2}{ }^{+1}$ & 291.1709 & 291.174 & 19.1 & MeLeu-Tyr \\
\hline $\mathbf{b}_{3}{ }^{+1}$ & 405.2138 & 405.2204 & 16.3 & MeLeu-Tyr-Asn \\
\hline $\mathbf{b}^{+1}$ & 864.3491 & 864.368 & 13.1 & MeLeu-Tyr-Asn-(L)Hpg m-Hpg-(D)Tyrm $_{m}$ \\
\hline $\mathbf{b}_{7}^{+1}$ & 1027.4202 & 1027.4375 & 16.9 & MeLeu-Tyr-Asn-(L)Hpg ${ }_{m}-H p g-(D) T_{y r}-$ Tyr \\
\hline $\mathrm{y}_{2}^{+1}$ & 223.1436 & 223.1468 & 19 & Tyr-propyl \\
\hline $\mathbf{y}_{6}+1$ & 796.3295 & 796.3424 & 16.3 & Asn-(L)Hpg ${ }_{m}-H p g-(D) T_{y r}$-Tyr-propyl \\
\hline $\mathbf{y}_{7}^{+1}$ & 959.3928 & 959.3989 & 6.3 & 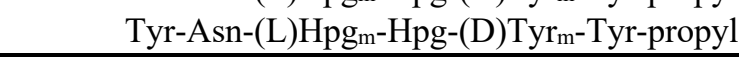 \\
\hline
\end{tabular}


Table S20. HR-MS/MS data for starting material AA2 $=$ D-Tyr and AA4 $=$ ortho ${ }^{2} \mathrm{H}_{2}-\mathrm{L}-\mathrm{Hpg}$ and products upon reaction with OxyB (-2 Da product, 23; and -3 Da product, 24).

HR-MS/MS for starting material AA2 $=D-T y r$ and $A A 4=$ ortho $^{2}{ }^{2} \mathrm{H}_{2}-\mathrm{L}-\mathrm{Hpg}$

\begin{tabular}{|c|c|c|c|c|}
\hline $\begin{array}{c}\text { Charge } \\
\text { State } \\
\end{array}$ & $\begin{array}{c}\text { Calculated } \\
\mathbf{m} / \mathbf{z}\end{array}$ & $\begin{array}{c}\text { Observed } \\
\mathbf{m} / \mathbf{z} \\
\end{array}$ & $\Delta \mathbf{p p m}$ & Sequence \\
\hline $\mathbf{b}_{2}{ }^{+1}$ & 291.1709 & 291.1708 & 0.1 & MeLeu-Tyr \\
\hline $\mathbf{b}_{3}{ }^{+1}$ & 405.2138 & 405.2161 & 5.7 & MeLeu-Tyr-Asn \\
\hline $\mathbf{b}_{4}^{+1}$ & 556.274 & 556.2767 & 4.9 & MeLeu-Tyr-Asn-(L) ${ }^{2} \mathrm{H}_{2} \mathrm{Hpg}$ \\
\hline$b_{5}^{+1}$ & 705.3217 & 705.3244 & 3.9 & MeLeu-Tyr-Asn-(L) ${ }^{2} \mathrm{H}_{2} \mathrm{Hpg}-\mathrm{Hpg}$ \\
\hline $\mathbf{b}_{6}{ }^{+1}$ & 868.385 & 868.3877 & 3.1 & MeLeu-Tyr-Asn-(L) ${ }^{2} \mathrm{H}_{2}$ Hpg-Hpg-(D)Tyr \\
\hline $\mathbf{b}_{7}^{+1}$ & 1031.4484 & 1031.452 & 3.5 & MeLeu-Tyr-Asn-(L) ${ }^{2} \mathrm{H}_{2}$ Hpg-Hpg-(D)Tyr-Tyr \\
\hline $\mathbf{y}_{2}{ }^{+1}$ & 223.1436 & 223.1413 & 9.9 & Tyr-propyl \\
\hline$y_{3}{ }^{+1}$ & 386.2069 & 386.2087 & 4.6 & (D)Tyr-Tyr-propyl \\
\hline$y_{4}{ }^{+1}$ & 535.2566 & 535.2566 & 0.1 & Hpg-(D)Tyr-Tyr-propyl \\
\hline$y_{5}+1$ & 686.3148 & 686.3179 & 4.5 & $(\mathrm{~L})^{2} \mathrm{H}_{2} \mathrm{Hpg}-\mathrm{Hpg}-(\mathrm{D}) \mathrm{Tyr}-\mathrm{Tyr}-$ propyl \\
\hline $\mathbf{y}_{6}{ }^{+1}$ & 800.3577 & 800.3615 & 4.8 & Asn-(L) ${ }^{2} \mathrm{H}_{2} \mathrm{Hpg}-\mathrm{Hpg}-(\mathrm{D}) \mathrm{Tyr}-\mathrm{Tyr}-$ propyl \\
\hline $\mathrm{y}_{7}^{+1}$ & 963.4211 & 963.4254 & 4.5 & Tyr-Asn-(L) ${ }^{2} \mathrm{H}_{2} \mathrm{Hpg}-\mathrm{Hpg}-(\mathrm{D}) \mathrm{Tyr}-\mathrm{Tyr}-$ propyl \\
\hline
\end{tabular}

HR-MS/MS for product $\mathbf{2 3}$ (-2Da product)

\begin{tabular}{|c|c|c|c|c|}
\hline $\begin{array}{l}\text { Charge } \\
\text { State }\end{array}$ & $\begin{array}{c}\text { Calculated } \\
\mathbf{m} / \mathbf{z}\end{array}$ & $\begin{array}{c}\text { Observed } \\
\mathbf{m} / \mathbf{z}\end{array}$ & $\Delta$ ppm & Sequence \\
\hline $\mathbf{b}_{2}^{+1}$ & 291.1709 & 291.1683 & 8.8 & MeLeu-Tyr \\
\hline $\mathbf{b}_{3}+1$ & 405.2138 & 405.2131 & 1.7 & MeLeu-Tyr-Asn \\
\hline $\mathbf{b}_{6}^{+1}$ & 866.3694 & 866.3734 & 4.6 & MeLeu-Tyr-Asn-(L) ${ }^{2} \mathrm{H}_{2} \mathrm{Hpg}_{\mathrm{m}}-\mathrm{Hpg}-(\mathrm{D}) \mathrm{Tyr}_{\mathrm{m}}$ \\
\hline $\mathbf{b}_{7}{ }^{+1}$ & 1029.4327 & 1029.4341 & 1.3 & MeLeu-Tyr-Asn-(L) ${ }^{2} \mathrm{H}_{2} \mathrm{Hpg}_{\mathrm{m}}-\mathrm{Hpg}$-(D)Tyr $\mathrm{m}-\mathrm{Tyr}$ \\
\hline $\mathbf{y}_{2}^{+1}$ & 223.1436 & 223.1436 & 15.7 & Tyr-propyl \\
\hline $\mathbf{y}^{+1}$ & 684.2991 & 684.2931 & 8.6 & (L) ${ }^{2} \mathrm{H}_{2} \mathrm{Hpg}_{\mathrm{m}}-\mathrm{Hpg}$-(D)Tyr $\mathrm{T}_{\mathrm{m}}$-Tyr-propyl \\
\hline $\mathbf{y}_{7}^{+1}$ & 961.4054 & 961.4013 & 4.2 & Tyr-Asn-(L) ${ }^{2} \mathrm{H}_{2} \mathrm{Hpg}_{\mathrm{m}}-\mathrm{Hpg}$-(D) $\mathrm{Tyr}_{\mathrm{m}}$-Tyr-propyl \\
\hline
\end{tabular}

HR-MS/MS for product 24 (-3Da product)

\begin{tabular}{|c|c|c|c|c|}
\hline $\begin{array}{c}\text { Charge } \\
\text { State } \\
\end{array}$ & $\begin{array}{c}\text { Calculated } \\
\mathbf{m} / \mathbf{z}\end{array}$ & $\begin{array}{c}\text { Observed } \\
\mathbf{m} / \mathbf{z} \\
\end{array}$ & $\Delta$ ppm & Sequence \\
\hline $\mathbf{b}_{2}{ }^{+1}$ & 291.1709 & 291.1679 & 9.9 & MeLeu-Tyr \\
\hline $\mathbf{b}_{3}{ }^{+1}$ & 405.2138 & 405.2146 & 2.0 & MeLeu-Tyr-Asn \\
\hline $\mathbf{b}_{6}{ }^{+1}$ & 865.3631 & 865.3581 & 5.6 & MeLeu-Tyr-Asn-(L) ${ }^{2} \mathrm{H}_{2} \mathrm{Hpg}_{\mathrm{m}}-\mathrm{Hpg}$-(D)Tyr $\mathrm{r}_{\mathrm{m}}$ \\
\hline $\mathbf{b}_{7}^{+1}$ & 1028.4264 & 1028.4303 & 3.7 & MeLeu-Tyr-Asn-(L) ${ }^{2} \mathrm{H}_{2} \mathrm{Hpg}_{\mathrm{m}}$-Hpg-(D)Tyr $\mathrm{r}_{\mathrm{m}}-\mathrm{Tyr}$ \\
\hline $\mathbf{y}_{2}{ }^{+1}$ & 223.1436 & 223.1436 & 6.9 & Tyr-propyl \\
\hline $\mathbf{y s}_{5}^{+1}$ & 683.2929 & 683.2947 & 2.6 & Asn-(L) ${ }^{2} \mathrm{H}_{2} \mathrm{Hpg}_{\mathrm{m}}-\mathrm{Hpg}$-(D)Tyr $\mathrm{r}_{\mathrm{m}}$-Tyr-propyl \\
\hline $\mathbf{y}_{7}^{+1}$ & 960.3991 & 960.3942 & 5.0 & Tyr-Asn-(L) ${ }^{2} \mathrm{H}_{2} \mathrm{Hpg}_{\mathrm{m}}-\mathrm{Hpg}$-(D)Tyr $\mathrm{Tr}_{\mathrm{m}}$-Tyr-propyl \\
\hline
\end{tabular}


Table S21. HR-MS data for substrates and products of OxyB enzymatic reactions to generate analogs with varying hydroxyl group substituents. Sequence of peptides shown is (AA1)-AA2(AA3)-AA4-(L-Asn5)-(D-Tyr6)-(N-Me-D-Leu7).

\begin{tabular}{|c|c|c|c|c|c|c|c|c|}
\hline Compound & AA1 & AA2 & $\mathbf{A A 3}$ & AA4 & $\begin{array}{c}\text { Charge } \\
\text { State } \\
\end{array}$ & $\begin{array}{c}\text { Calculated } \\
\text { mass }\end{array}$ & $\begin{array}{c}\text { Observed } \\
\text { mass }\end{array}$ & $\Delta \mathrm{ppm}$ \\
\hline 25 & L-Tyr & L-Tyr & D-Hpg & D-PhGly & {$[\mathrm{M}+\mathrm{H}]^{+}$} & 1072.5138 & 1072.51447 & 0.6 \\
\hline 26 & L-Tyr & L-Tyr & D-Hpg & D-PhGly & {$[\mathrm{M}+\mathrm{H}]^{+}$} & 1070.4982 & 1070.49859 & 0.3 \\
\hline 27 & L-Tyr & L-Phe & D-Hpg & D-Hpg & {$[\mathrm{M}+\mathrm{H}]^{+}$} & 1072.5138 & 1072.51447 & 0.7 \\
\hline 28-31 & L-Tyr & L-Phe & D-Hpg & D-Hpg & {$[\mathrm{M}+\mathrm{H}]^{+}$} & 1070.4982 & 1070.49859 & 0.1 \\
\hline S1 & L-Tyr & ${ }^{2} \mathrm{H}_{5}$-L-Phe & D-Hpg & D-Hpg & {$[\mathrm{M}+\mathrm{H}]^{+}$} & 1077.5452 & 1077.55852 & 12.3 \\
\hline S1-S5 & L-Tyr & ${ }^{2} \mathrm{H}_{5}$-L-Phe & D-Hpg & D-Hpg & {$[\mathrm{M}+\mathrm{H}]^{+}$} & 1075.5296 & 1075.54143 & 10.9 \\
\hline S6 & ${ }^{2} \mathrm{H}_{2}-\mathrm{L}-\mathrm{Tyr}$ & L-Phe & D-Hpg & D-Hpg & {$[\mathrm{M}+\mathrm{H}]^{+}$} & 1074.5264 & 1074.53947 & 12.1 \\
\hline S7-S9 & ${ }^{2} \mathrm{H}_{2}-\mathrm{L}-\mathrm{Tyr}$ & L-Phe & D-Hpg & D-Hpg & {$[\mathrm{M}+\mathrm{H}]^{+}$} & 1072.5107 & 1072.516 & 4.9 \\
\hline S10 & ${ }^{2} \mathrm{H}_{2}-\mathrm{L}-\mathrm{Tyr}$ & L-Phe & D-Hpg & D-Hpg & {$[\mathrm{M}+\mathrm{H}]^{+}$} & 1071.5045 & 1071.50939 & 4.5 \\
\hline S11 & L-Tyr & L-Phe & D-Hpg & ${ }^{2} \mathrm{H}_{2}$-D-Hpg & {$[\mathrm{M}+\mathrm{H}]^{+}$} & 1074.5264 & 1074.53615 & 9.0 \\
\hline $\mathrm{S} 12,14,15$ & L-Tyr & L-Phe & D-Hpg & ${ }^{2} \mathrm{H}_{2}$-D-Hpg & {$[\mathrm{M}+\mathrm{H}]^{+}$} & 1072.5107 & 1072.51929 & 8.0 \\
\hline S13 & L-Tyr & L-Phe & D-Hpg & ${ }^{2} \mathrm{H}_{2}$-D-Hpg & {$[\mathrm{M}+\mathrm{H}]^{+}$} & 1071.5045 & 1071.5139 & 8.7 \\
\hline S16 & L-Tyr & L-Phe & ${ }^{2} \mathrm{H}_{2}$-D-Hpg & D-Hpg & {$[\mathrm{M}+\mathrm{H}]^{+}$} & 1074.5264 & 1074.54043 & 13.0 \\
\hline S18, S20 & L-Tyr & L-Phe & ${ }^{2} \mathrm{H}_{2}$-D-Hpg & D-Hpg & {$[\mathrm{M}+\mathrm{H}]^{+}$} & 1072.5107 & 1072.51987 & 8.5 \\
\hline S17, S19 & L-Tyr & L-Phe & ${ }^{2} \mathrm{H}_{2}$-D-Hpg & D-Hpg & {$[\mathrm{M}+\mathrm{H}]^{+}$} & 1071.5045 & 1071.51482 & 9.6 \\
\hline 32 & L-Tyr & L-Phe & D-Hpg & D-PhGly & {$[\mathrm{M}+\mathrm{H}]^{+}$} & 1056.5189 & 1056.52202 & 2.9 \\
\hline 33 & L-Tyr & L-Phe & D-Hpg & D-PhGly & {$[\mathrm{M}+\mathrm{H}]^{+}$} & 1054.5033 & 1054.50517 & 1.7 \\
\hline
\end{tabular}


Table S22. HR-MS/MS data for starting material 25 (AA2 = L-Tyr, AA4 = D-PhGly) and product 26.

HR-MS/MS for starting material $25(A A 2=L-T y r, A A 4=D-P h G l y)$

\begin{tabular}{ccccl}
\hline $\begin{array}{c}\text { Charge } \\
\text { State }\end{array}$ & $\begin{array}{c}\text { Calculated } \\
\mathbf{m} / \mathbf{z}\end{array}$ & $\begin{array}{c}\text { Observed } \\
\mathbf{m} / \mathbf{z}\end{array}$ & $\boldsymbol{\Delta} \mathbf{p p m}$ & \multicolumn{1}{c}{ Sequence } \\
\hline $\mathbf{b}_{2}{ }^{+1}$ & 291.1709 & 291.1713 & 1.6 & MeLeu-Tyr \\
$\mathbf{b}^{+1}$ & 405.2138 & 405.2147 & 2.4 & MeLeu-Tyr-Asn \\
$\mathbf{b}_{4}{ }^{+1}$ & 538.2666 & 538.2690 & 4.6 & MeLeu-Tyr-Asn-PhGly \\
$\mathbf{b}_{5}{ }^{+1}$ & 687.3142 & 687.3164 & 3.3 & MeLeu-Tyr-Asn-PhGly-Hpg \\
$\mathbf{b}_{6}{ }^{+1}$ & 850.3776 & 850.3811 & 4.1 & MeLeu-Tyr-Asn-PhGly-Hpg-Tyr \\
$\mathbf{b}_{7}{ }^{+1}$ & 1013.4409 & 1013.4449 & 3.9 & MeLeu-Tyr-Asn-PhGly-Hpg-Tyr-Tyr \\
\hline $\mathbf{y}_{2}{ }^{+1}$ & 223.1436 & 223.1450 & 6.6 & Tyr-propyl \\
$\mathbf{y}_{3}{ }^{+1}$ & 386.2069 & 386.2075 & 1.7 & Tyr-Tyr-propyl \\
$\mathbf{y}^{+1}$ & 535.2536 & 535.2627 & 17.1 & Hpg-Tyr-Tyr-propyl \\
$\mathbf{y}_{5}{ }^{+1}$ & 668.3073 & 668.3117 & 6.6 & PhGly-Hpg-Tyr-Tyr-propyl \\
$\mathbf{y}_{6}{ }^{+1}$ & 782.3503 & 782.3610 & 13.6 & Asn-PhGly-Hpg-Tyr-Tyr-propyl \\
$\mathbf{y}_{\mathbf{7}}{ }^{+1}$ & 945.4136 & 945.4128 & 0.7 & Tyr-Asn-PhGly-Hpg-Tyr-Tyr-propyl \\
\hline
\end{tabular}

HR-MS/MS for product $\mathbf{2 6}(A A 2=L-T y r, A A 4=D-P h G l y)$

\begin{tabular}{|c|c|c|c|c|}
\hline $\begin{array}{c}\text { Charge } \\
\text { State }\end{array}$ & $\begin{array}{c}\text { Calculated } \\
\mathbf{m} / \mathbf{z}\end{array}$ & $\begin{array}{c}\text { Observed } \\
\mathbf{m} / \mathbf{z}\end{array}$ & $\Delta$ ppm & Sequence \\
\hline$\overline{\mathbf{b}_{2}+1}$ & 291.1709 & 291.1715 & 2.2 & MeLeu-Tyr \\
\hline $\mathbf{b}_{3}{ }^{+1}$ & 405.2138 & 405.2149 & 2.9 & MeLeu-Tyr-Asn \\
\hline $\mathrm{b}^{+1}$ & 538.2666 & 538.2679 & 2.4 & MeLeu-Tyr-Asn-PhGly \\
\hline$b_{5}^{+1}$ & 687.3142 & 687.3072 & 10 & MeLeu-Tyr-Asn-PhGly-Hpg-Tyr ${ }_{m}-$ Tyr $_{m}$ \\
\hline $\mathbf{b}_{7}{ }^{+1}$ & 1011.4252 & 1011.4225 & 2.6 & MeLeu-Tyr-Asn-PhGly-Hpg-Tyr ${ }_{m}-$ Tyr $_{m}$ \\
\hline $\mathrm{y}_{3}{ }^{+1}$ & 384.1912 & 384.1930 & 4.7 & Tyr ${ }_{m}-$ Tyr $_{m}$-propyl \\
\hline $\mathrm{y}_{4}^{+1}$ & 533.2389 & 533.2468 & 14.9 & Hpg-Tyr - Tyrm$_{m}$-propyl \\
\hline$y_{5}+1$ & 666.2917 & 666.2963 & 6.9 & PhGly-Hpg-Tyr ${ }_{m}-T_{y r}$-propyl \\
\hline$y_{6}{ }^{+1}$ & 780.3346 & 780.3365 & 2.5 & Asn-PhGly-Hpg-Tyr ${ }_{m}-T_{y r}$-propyl \\
\hline $\mathrm{y}_{7}^{+1}$ & 943.3979 & 943.4005 & 2.7 & Tyr-Asn-PhGly-Hpg-Tyrm-Tyrm-propyl \\
\hline
\end{tabular}


Table S23. NMR assignments for 25 in $\left(\mathrm{CD}_{3}\right)_{2} \mathrm{SO}$ from $\mathrm{C}$ - to N-terminus. The structure and number scheme for the compound is shown below the table.

\begin{tabular}{|c|c|c|c|}
\hline Residue & Label & $\delta H(p p m)$ & $\delta \mathrm{C}(\mathrm{ppm})$ \\
\hline \multirow[t]{5}{*}{ Tyr1 } & 2 & 4.33 & 545.8 \\
\hline & 3 & 2.75 & - \\
\hline & 5 & 6.95 & 115.3 \\
\hline & 6 & 6.62 & 130.4 \\
\hline & $\mathrm{NH}$ & 8.04 & - \\
\hline \multirow[t]{5}{*}{ Tyr2 } & 2 & 4.30 & 54.9 \\
\hline & 3 & $2.68 ; 2.53$ & - \\
\hline & 5 & 6.73 & 130.6 \\
\hline & 6 & 6.47 & 115.2 \\
\hline & $\mathrm{NH}$ & 8.14 & - \\
\hline \multirow[t]{5}{*}{ Hpg3 } & 1 & - & 170.1 \\
\hline & 2 & 5.38 & 56.2 \\
\hline & 4 & 7.02 & 128.8 \\
\hline & 5 & 6.63 & 115.3 \\
\hline & $\mathrm{NH}$ & 8.86 & - \\
\hline \multirow[t]{5}{*}{ PhGly4 } & 1 & - & 169.4 \\
\hline & 2 & 5.65 & 56.1 \\
\hline & 4 & 7.39 & 127.3 \\
\hline & 5 & 7.23 & 128.6 \\
\hline & $\mathrm{NH}$ & 8.19 & - \\
\hline \multirow[t]{4}{*}{ Asn5 } & 1 & - & 170.7 \\
\hline & 2 & 4.64 & 50.2 \\
\hline & 3 & $2.47 ; 2.34$ & - \\
\hline & $\mathrm{NH}$ & 8.29 & - \\
\hline \multirow[t]{5}{*}{ Tyr6 } & 2 & 4.53 & 53.9 \\
\hline & 3 & $2.64 ; 2.88$ & - \\
\hline & 5 & 6.96 & 130.6 \\
\hline & 6 & 6.59 & 115.1 \\
\hline & $\mathrm{NH}$ & 7.94 & - \\
\hline
\end{tabular}

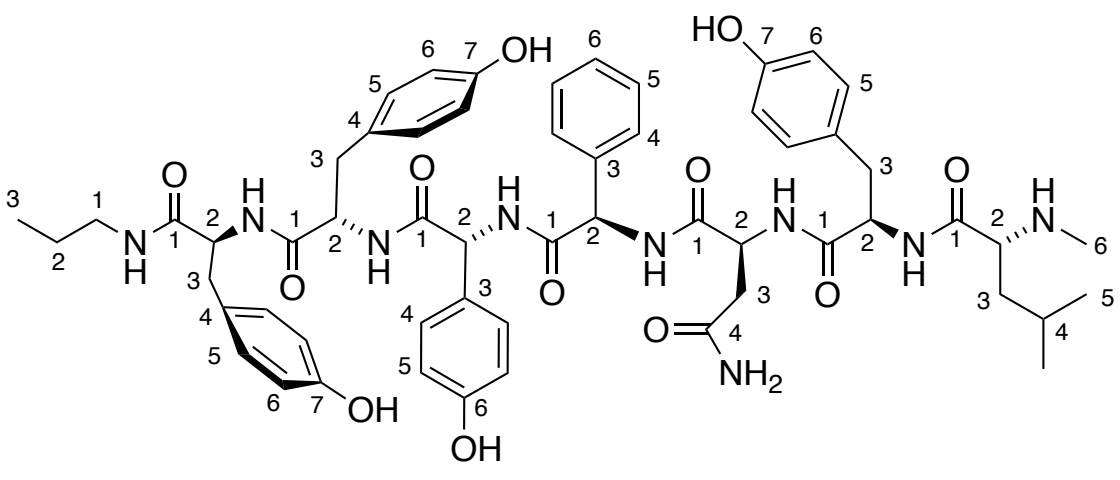


Table S24. NMR assignments for 26 in $\left(\mathrm{CD}_{3}\right)_{2} \mathrm{SO}$ from $\mathrm{C}$ - to N-terminus. The structure and number scheme for the compound is shown below the table.

\begin{tabular}{llll}
\hline \hline Residue & Label & $\mathbf{\delta H}(\mathbf{p p m})$ & $\mathbf{\delta C}(\mathbf{p p m})$ \\
\hline \hline Pr & NH & 7.50 & - \\
\hline Tyr1 & 2 & 4.23 & 56.9 \\
& 3 & $2.94 ; 2.81$ & - \\
& 5 & 7.02 & 140.8 \\
& 8 & 6.64 & 115.7 \\
& 9 & 6.97 & 130.6 \\
\hline Tyr2 & NH & 8.09 & - \\
& 2 & 4.50 & 55.6 \\
& 3 & $2.28 ; 3.32$ & - \\
& 5 & 6.55 & 139.6 \\
& 8 & 6.55 & 115.3 \\
& 9 & 6.39 & 129.6 \\
\hline Hpg3 & NH & 7.46 & - \\
& 2 & 5.45 & 56.6 \\
& 4 & 7.17 & 129.4 \\
& 5 & 6.78 & 115.7 \\
\hline PhGly4 & NH & 8.94 & - \\
& 2 & 5.62 & 56.1 \\
& 4 & 7.39 & 127.4 \\
& 5 & 7.28 & 128.6 \\
& 6 & 7.26 & - \\
\hline Asn5 & NH & 8.37 & - \\
\hline Tyr6 & 2 & 4.63 & 50.0 \\
& 3 & $2.34 ; 2.45$ & - \\
& NH & 8.32 & - \\
\hline & 2 & 4.51 & 53.9 \\
& 5 & $2.86 ; 2.64$ & - \\
& 6 & 6.97 & 128.5 \\
& NH & 6.61 & 115.2 \\
& & 7.93 & - \\
\hline & & &
\end{tabular}<smiles>CCCNC(=O)[C@H]1Cc2ccc(O)c(c2)-c2cc(ccc2O)C[C@@H](NC(=O)[C@H](NC(=O)[C@H](NC(=O)[C@H](CC(N)=O)NC(=O)[C@H](Cc2ccc(O)cc2)NC(=O)[C@H](CC(C)C)NC)c2ccc(O)cc2)c2ccccc2)C(=O)N1</smiles> 
Table S25. HR-MS/MS for substrate S1, with isotopically labelled AA2 ( $\left.{ }^{2} \mathrm{H}_{5}-\mathrm{L}-\mathrm{Phe}\right)$, and -2 Da products obtained upon reaction with OxyB $(\mathbf{S 2}, \mathbf{S 3}, \mathbf{S 4})$.

HR-MS/MS for substrate S1, containing labelled AA2 $\left({ }^{2} H_{5}-L-P h e\right)$

\begin{tabular}{ccccl}
\hline $\begin{array}{c}\text { Charge } \\
\text { State }\end{array}$ & $\begin{array}{c}\text { Calculated } \\
\mathbf{m} / \mathbf{z}\end{array}$ & $\begin{array}{c}\text { Observed } \\
\mathbf{m} / \mathbf{z}\end{array}$ & \multicolumn{1}{|c}{$\mathbf{p p m}$} & \multicolumn{1}{c}{ Sequence } \\
\hline $\mathbf{b}_{1}{ }^{+1}$ & 128.1075 & 128.1094 & 14.8 & MeLeu \\
$\mathbf{b}^{+1}$ & 291.1709 & 291.1755 & 15.7 & MeLeu-Tyr \\
$\mathbf{b}_{3}{ }^{+1}$ & 405.2138 & 405.2206 & 16.7 & MeLeu-Tyr-Asn \\
$\mathbf{b}_{4}{ }^{+1}$ & 554.2615 & 554.2708 & 16.7 & MeLeu-Tyr-Asn-Hpg \\
$\mathbf{b}_{5}{ }^{+1}$ & 703.3092 & 703.3205 & 16.0 & MeLeu-Tyr-Asn-Hpg-Hpg \\
$\mathbf{b}_{6}{ }^{+1}$ & 855.4089 & 855.4222 & 15.5 & MeLeu-Tyr-Asn-Hpg-Hpg- ${ }^{2} \mathrm{H}_{5}$ Phe \\
$\mathbf{b}_{7}{ }^{+1}$ & 1018.472 & 1018.488 & 15.6 & MeLeu-Tyr-Asn-Hpg-Hpg- ${ }^{2} \mathrm{H}_{5}$ Phe-Tyr \\
\hline $\mathbf{y}_{2}{ }^{+1}$ & 223.1426 & 223.1482 & 20.6 & Tyr-propyl \\
$\mathbf{y}_{3}{ }^{+1}$ & 375.2434 & 375.2499 & 17.3 & ${ }^{2} \mathrm{H}_{5}$ Phe-Tyr-propyl \\
$\mathbf{y}_{4}{ }^{+1}$ & 524.291 & 524.299 & 15.2 & Hpg- ${ }^{2} \mathrm{H}_{5}$ Phe-Tyr-propyl \\
$\mathbf{y}_{5}{ }^{+1}$ & 673.2287 & 673.349 & 15.2 & Hpg-Hpg- ${ }^{2} \mathrm{H}_{5}$ Phe-Tyr-propyl \\
$\mathbf{y}_{6}{ }^{+1}$ & 787.3816 & 787.3934 & 14.9 & Asn-Hpg-Hpg- ${ }^{2}{ }_{5}$ Phe-Tyr-propyl \\
$\mathbf{y}_{7}{ }^{+1}$ & 950.445 & 950.4607 & 16.5 & Tyr-Asn-Hpg-Hpg- ${ }^{2} \mathrm{H}_{5}$ Phe-Tyr-propyl \\
\hline
\end{tabular}

HR-MS/MS for -2 Da products $\boldsymbol{S} 2, \boldsymbol{S} 3, \boldsymbol{S} 4$, containing labelled AA2 $\left({ }^{2} H_{5}-L-P h e\right)$

\begin{tabular}{ccccl}
\hline $\begin{array}{c}\text { Charge } \\
\text { State }\end{array}$ & $\begin{array}{c}\text { Calculated } \\
\mathbf{m} / \mathbf{z}\end{array}$ & $\begin{array}{c}\text { Observed } \\
\mathbf{m} / \mathbf{z}\end{array}$ & $\boldsymbol{\Delta} \mathbf{p p m}$ & \multicolumn{1}{c}{ Sequence } \\
\hline $\mathbf{b}{ }^{+1}$ & 291.1709 & 291.1756 & 16.1 & MeLeu-Tyr \\
$\mathbf{b}_{3}{ }^{+1}$ & 405.2138 & 405.22 & 15.3 & MeLeu-Tyr-Asn \\
$\mathbf{b}_{4}{ }^{+1}$ & 554.2615 & 554.2615 & 15.5 & MeLeu-Tyr-Asn-Hpg \\
$\mathbf{b}_{5}{ }^{+1}$ & 701.2935 & 701.3025 & 12.8 & MeLeu-Tyr-Asn-Hpg-Hpg \\
$\mathbf{b}_{5}{ }^{+1}$ & 703.3092 & 703.3192 & 14.2 & MeLeu-Tyr-Asn-Hpg-Hpg \\
$\mathbf{b}_{6}{ }^{+1}$ & 853.3933 & 853.4071 & 16.1 & MeLeu-Tyr-Asn-Hpg-Hpg- ${ }^{2} \mathrm{H}_{5}$ Phe \\
$\mathbf{b}_{7}{ }^{+1}$ & 1016.4566 & 1016.4707 & 13.8 & MeLeu-Tyr-Asn-Hpg-Hpg- ${ }^{2} \mathrm{H}_{5}$ Phe-Tyr \\
\hline $\mathbf{y}_{2}{ }^{+1}$ & 223.1436 & 223.1478 & 18.8 & Tyr-propyl \\
$\mathbf{y}_{4}{ }^{+1}$ & 522.2754 & 522.2848 & 17.9 & Hpg- ${ }^{2} \mathrm{H}_{5}$ Phe-Tyr-propyl \\
$\mathbf{y}_{5}{ }^{+1}$ & 671.3231 & 671.3294 & 9.3 & Hpg-Hpg- ${ }^{2} \mathrm{H}_{5}$ Phe-Tyr-propyl \\
$\mathbf{y}_{6}{ }^{+1}$ & 785.366 & 785.3785 & 15.9 & Asn-Hpgm-Hpg- ${ }^{2} \mathrm{H}_{5}$ Phe-Tyr-propyl \\
$\mathbf{y}_{7}{ }^{+1}$ & 948.4423 & 948.4293 & 13.7 & Tyr-Asn-Hpg-Hpg- ${ }^{2} \mathrm{H}_{5}$ Phe-Tyr-propyl \\
\hline
\end{tabular}


Table S26. HR-MS/MS for substrate S6, with isotopically labelled AA1 (ortho- ${ }^{2} \mathrm{H}_{2}-\mathrm{L}-\mathrm{Ty}$ ), and products obtained upon reaction with OxyB (-2 Da products, S7, S8, S9; -3Da product, S10).

HR-MS/MS for substrate S6, containing labelled AA1 (ortho- ${ }^{2} \mathrm{H}_{2}-\mathrm{L}-\mathrm{Ty}$ )

\begin{tabular}{|c|c|c|c|c|}
\hline $\begin{array}{c}\text { Charge } \\
\text { State }\end{array}$ & $\begin{array}{c}\text { Calculated } \\
\mathrm{m} / \mathrm{z}\end{array}$ & $\begin{array}{c}\text { Observed } \\
\mathbf{m} / \mathbf{z}\end{array}$ & $\Delta p p m$ & Sequence \\
\hline $\mathbf{b}_{2}^{+1}$ & 291.1709 & 291.1771 & 21.2 & MeLeu-Tyr \\
\hline $\mathbf{b}_{3}{ }^{+1}$ & 405.2138 & 405.2229 & 22.4 & MeLeu-Tyr-Asn \\
\hline $\mathbf{b}_{4}{ }^{+1}$ & 554.2615 & 554.2741 & 22.7 & MeLeu-Tyr-Asn-Hpg \\
\hline$b_{5}{ }^{+1}$ & 703.3092 & 703.3237 & 20.6 & MeLeu-Tyr-Asn-Hpg-Hpg \\
\hline $\mathbf{b}_{6}{ }^{+1}$ & 850.3776 & 850.3958 & 21.4 & MeLeu-Tyr-Asn-Hpg-Hpg-Phe \\
\hline $\mathbf{b}_{7}^{+1}$ & 1015.453 & 1015.475 & 21.2 & MeLeu-Tyr-Asn-Hpg-Hpg-Phe- ${ }^{2} \mathrm{H}_{2} \mathrm{Tyr}$ \\
\hline $\mathbf{y}_{2}^{+1}$ & 225.1561 & 225.1619 & 25.7 & ${ }^{2} \mathrm{H}_{2}$ Tyr-propyl \\
\hline $\mathbf{y}_{3}{ }^{+1}$ & 372.2245 & 372.2331 & 23.1 & Phe- ${ }^{2} \mathrm{H}_{2}$ Tyr-propyl \\
\hline $\mathbf{y}_{4}^{+1}$ & 521.2722 & 521.2831 & 20.9 & Hpg-Phe-- ${ }^{2} \mathrm{H}_{2}$ Tyr-propyl \\
\hline $\mathbf{y s}^{+1}$ & 670.3199 & 670.3263 & 9.5 & Hpg-Hpg-Phe- ${ }^{2} \mathrm{H}_{2}$ Tyr-propyl \\
\hline $\mathbf{y}_{6}{ }^{+1}$ & 784.3628 & 784.3791 & 20.7 & Asn-Hpg-Hpg-Phe- ${ }^{2} \mathrm{H}_{2}$ Tyr-propyl \\
\hline $\mathbf{y}_{7}^{+1}$ & 947.4261 & 947.4468 & 21.8 & Tyr-Asn-Hpg-Hpg-Phe- ${ }^{2} \mathrm{H}_{2} \mathrm{Tyr}-$ propyl \\
\hline
\end{tabular}

HR-MS/MS for -2 Da products $\boldsymbol{S} 7, \boldsymbol{S} 8, \boldsymbol{S} 9$, containing labelled AA1 (ortho- ${ }^{2} \mathrm{H}_{2}-L-T y r$ )

\begin{tabular}{ccccl}
\hline $\begin{array}{c}\text { Charge } \\
\text { State }\end{array}$ & $\begin{array}{c}\text { Calculated } \\
\mathbf{m} / \mathbf{z}\end{array}$ & $\begin{array}{c}\text { Observed } \\
\mathbf{m} / \mathbf{z}\end{array}$ & \multicolumn{1}{|c}{$\mathbf{p p m}$} & \multicolumn{1}{c}{ Sequence } \\
\hline $\mathbf{b}_{2}{ }^{+1}$ & 291.1709 & 291.1771 & 21.2 & MeLeu-Tyr \\
$\mathbf{b}_{3}{ }^{+1}$ & 405.2138 & 405.222 & 20.2 & MeLeu-Tyr-Asn \\
$\mathbf{b}^{+1}$ & 554.2615 & 554.2746 & 23.6 & MeLeu-Tyr-Asn-Hpg \\
$\mathbf{b}_{5}{ }^{+1}$ & 701.2935 & 701.3042 & 15.2 & MeLeu-Tyr-Asn-Hpg-Hpg \\
$\mathbf{b}_{5}{ }^{+1}$ & 703.3092 & 703.319 & 13.9 & MeLeu-Tyr-Asn-Hpg-Hpg \\
$\mathbf{b}_{6}{ }^{+1}$ & 848.3619 & 848.3733 & 13.4 & MeLeu-Tyr-Asn-Hpg-Hpg-Phe \\
$\mathbf{b}_{6}{ }^{+1}$ & 850.3776 & 850.3933 & 18.4 & MeLeu-Tyr-Asn-Hpg-Hpg-Phe \\
$\mathbf{b}_{7}{ }^{+1}$ & 1013.438 & 1013.456 & 18.4 & MeLeu-Tyr-Asn-Hpg-Hpg-Phe- ${ }^{2} \mathrm{H}_{2}$ Tyr \\
\hline $\mathbf{y}_{2}{ }^{+1}$ & 225.1561 & 225.1613 & 23.1 & \\
$\mathbf{y}_{5}{ }^{+1}$ & 668.3042 & 668.3211 & 25.2 & ${ }^{2} \mathrm{H}_{2}$ Tyr-propyl \\
$\mathbf{y}_{6}{ }^{+1}$ & 782.3472 & 782.3674 & 25.8 & Hpg-Hpg-Phe- ${ }^{2} \mathrm{H}_{2}$ Tyr-propyl \\
$\mathbf{y}_{7}{ }^{+1}$ & 945.4105 & 945.429 & 19.5 & Asn-Hpg-Hpg-Phe- ${ }^{2} \mathrm{H}_{2}$ Tyr-propyl \\
\hline
\end{tabular}

HR-MS/MS for -3 Da products S10, containing labelled AAI (ortho- ${ }^{2} \mathrm{H}_{2}-\mathrm{L}-\mathrm{Tyr}$ )

\begin{tabular}{|c|c|c|c|c|}
\hline $\begin{array}{c}\text { Charge } \\
\text { State } \\
\end{array}$ & $\begin{array}{c}\text { Calculated } \\
\mathrm{m} / \mathrm{z}\end{array}$ & $\begin{array}{c}\text { Observed } \\
\mathbf{m} / \mathbf{z}\end{array}$ & $\Delta \mathbf{p p m}$ & Sequence \\
\hline $\mathbf{b}_{2}{ }^{+1}$ & 291.1709 & 291.1757 & 16.4 & MeLeu-Tyr \\
\hline $\mathbf{b}_{3}{ }^{+1}$ & 405.2138 & 405.2218 & 19.7 & MeLeu-Tyr-Asn \\
\hline $\mathbf{b}^{+1}$ & 554.2615 & 554.2692 & 13.8 & MeLeu-Tyr-Asn-Hpg \\
\hline $\mathbf{b}_{7}{ }^{+1}$ & 1012.432 & 1012.446 & 13.9 & MeLeu-Tyr-Asn-Hpg-Hpg ${ }_{m}-\mathrm{Phe}^{2}{ }^{2} \mathrm{H}_{2} \mathrm{Tyr}_{\mathrm{m}}$ \\
\hline$y_{4}{ }^{+1}$ & 518.2503 & 518.2556 & 10.2 & ${ }^{2} \mathrm{H}_{2} \mathrm{Tyr}_{\mathrm{m}}$-propyl \\
\hline $\mathbf{y}_{6}+1$ & 781.3409 & 781.3564 & 19.8 & Asn-Hpg-Hpg $m-P h e-{ }^{2} \mathrm{H}_{2} \mathrm{Tyr}_{\mathrm{m}}$-propyl \\
\hline $\mathbf{y}_{7}^{+1}$ & 944.4042 & 944.4178 & 14.4 & Tyr-Asn-Hpg-Hpg $-\mathrm{Phe}^{2}{ }^{2} \mathrm{H}_{2} \mathrm{Tyr}_{\mathrm{m}}$-propyl \\
\hline
\end{tabular}


Table S27. HR-MS/MS for substrate S11, with isotopically labelled AA4 (ortho- ${ }^{2} \mathrm{H}_{2}-\mathrm{D}-\mathrm{Hpg} 4$ ), and products obtained upon reaction with OxyB (-2 Da products, S12, S14, S15; -3Da product, S13).

HR-MS/MS for substrate 38, containing labelled AA4 (ortho- ${ }^{2} \mathrm{H}_{2}-\mathrm{D}-H p g 4$ )

\begin{tabular}{ccccl}
\hline $\begin{array}{c}\text { Charge } \\
\text { State }\end{array}$ & $\begin{array}{c}\text { Calculated } \\
\mathbf{m} / \mathbf{z}\end{array}$ & $\begin{array}{c}\text { Observed } \\
\mathbf{m} / \mathbf{z}\end{array}$ & \multicolumn{1}{|c}{$\mathbf{p p m}$} & \multicolumn{1}{c}{ Sequence } \\
\hline $\mathbf{b}_{2}{ }^{+1}$ & 291.1709 & 291.1699 & 3.5 & MeLeu-Tyr \\
$\mathbf{b}_{3}{ }^{+1}$ & 405.2138 & 405.2182 & 10.9 & MeLeu-Tyr-Asn \\
$\mathbf{b}_{4}{ }^{+1}$ & 556.274 & 556.2789 & 8.8 & MeLeu-Tyr-Asn-Hpg \\
$\mathbf{b}_{5}{ }^{+1}$ & 705.3217 & 705.3257 & 5.6 & MeLeu-Tyr-Asn- ${ }^{2} \mathrm{H}_{2}$ Hpg-Hpg \\
$\mathbf{b}_{6}{ }^{+1}$ & 852.3901 & 852.3931 & 3.6 & MeLeu-Tyr-Asn- ${ }^{2} \mathrm{H}_{2}$ Hpg-Hpg-Phe \\
$\mathbf{b}_{7}{ }^{+1}$ & 1015.4534 & 1015.4576 & 4.1 & MeLeu-Tyr-Asn- ${ }^{2} \mathrm{H}_{2}$ Hpg-Hpg-Phe-Tyr \\
\hline $\mathbf{y}_{3}{ }^{+1}$ & 370.212 & 370.2164 & 11.8 & Phe-Tyr-propyl \\
$\mathbf{y}_{5}{ }^{+1}$ & 670.3199 & 670.3218 & 2.9 & ${ }^{2} \mathrm{H}_{2}$ Hpg-Hpg-Phe-Tyr-propyl \\
$\mathbf{y}_{6}{ }^{+1}$ & 784.3628 & 784.3628 & 1.5 & Asn- ${ }^{2} \mathrm{H}_{2}$ Hpg-Hpg-Phe-Tyr-propyl \\
$\mathbf{y}_{7}{ }^{+1}$ & 947.4261 & 947.4315 & 5.7 & Tyr-Asn- ${ }^{2} \mathrm{H}_{2}$ Hpg-Hpg-Phe-Tyr-propyl \\
\hline
\end{tabular}

HR-MS/MS for -2 Da products S12, S14, S15, containing labelled AA4 (ortho- ${ }^{2} \mathrm{H}_{2}-\mathrm{D}-\mathrm{Hpg} 4$ )

\begin{tabular}{ccccl}
\hline $\begin{array}{c}\text { Charge } \\
\text { State }\end{array}$ & $\begin{array}{c}\text { Calculated } \\
\mathbf{m} / \mathbf{z}\end{array}$ & $\begin{array}{c}\text { Observed } \\
\mathbf{m} / \mathbf{z}\end{array}$ & $\boldsymbol{\Delta} \mathbf{p p m}$ & \multicolumn{1}{c}{ Sequence } \\
\hline $\mathbf{b}_{2}{ }^{+1}$ & 291.1709 & 291.1701 & 2.5 & MeLeu-Tyr \\
$\mathbf{b}_{3}{ }^{+1}$ & 405.2138 & 405.2181 & 10.6 & MeLeu-Tyr-Asn \\
$\mathbf{b}_{6}{ }^{+1}$ & 850.3843 & 850.3722 & 2.7 & MeLeu-Tyr-Asn- ${ }^{2} \mathrm{H}_{2}$ Hpg-Hpg-Phe \\
$\mathbf{b}_{7}{ }^{+1}$ & 1013.4549 & 1013.4349 & 2.8 & MeLeu-Tyr-Asn- ${ }^{2} \mathrm{H}_{2}$ Hpg-Hpg-Phe-Tyr \\
\hline $\mathbf{y}_{6}{ }^{+1}$ & 782.3472 & 782.3493 & 2.7 & Asn- ${ }^{2} \mathrm{H}_{2}$ Hpg-Hpg-Phe-Tyr-propyl \\
$\mathbf{y}_{7}{ }^{+1}$ & 945.4105 & 945.403 & 7.9 & Tyr-Asn- ${ }^{2} \mathrm{H}_{2}$ Hpg-Hpg-Phe-Tyr-propyl \\
\hline
\end{tabular}

HR-MS/MS for -3 Da product S13 containing labelled AA4 (ortho- ${ }^{2} \mathrm{H}_{2}-\mathrm{D}-\mathrm{Hpg} 4$ )

\begin{tabular}{|c|c|c|c|c|}
\hline $\begin{array}{c}\text { Charge } \\
\text { State } \\
\end{array}$ & $\begin{array}{c}\text { Calculated } \\
\mathrm{m} / \mathrm{z}\end{array}$ & $\begin{array}{c}\text { Observed } \\
\mathbf{m} / \mathbf{z}\end{array}$ & $\Delta p p m$ & Sequence \\
\hline $\mathbf{b}_{2}^{+1}$ & 291.1709 & 291.1726 & 5.9 & MeLeu-Tyr \\
\hline $\mathbf{b}_{3}{ }^{+1}$ & 405.2138 & 405.2127 & 8.7 & MeLeu-Tyr-Asn \\
\hline $\mathbf{b}_{5}^{+1}$ & 702.2998 & 702.3038 & 5.6 & MeLeu-Tyr-Asn- ${ }^{2} \mathrm{H}_{2} \mathrm{Hpg}_{\mathrm{m}}-\mathrm{Hpg}_{\mathrm{m}}$ \\
\hline $\mathbf{b}_{6}{ }^{+1}$ & 849.3642 & 849.3741 & 6.9 & MeLeu-Tyr-Asn- ${ }^{2} \mathrm{H}_{2} \mathrm{Hpg}_{\mathrm{m}}-\mathrm{Hpg}_{\mathrm{m}}-\mathrm{Phe}$ \\
\hline $\mathbf{b}_{7}{ }^{+1}$ & 1012.432 & 1012.447 & 15.2 & MeLeu-Tyr-Asn- ${ }^{2} \mathrm{H}_{2} \mathrm{Hpg}_{\mathrm{m}}-\mathrm{Hpg}_{\mathrm{m}}$-Phe-Tyr \\
\hline $\mathrm{y}_{6}{ }^{+1}$ & 781.3409 & 781.3618 & 26.7 & Asn- ${ }^{2} \mathrm{H}_{2} \mathrm{Hpg}_{\mathrm{m}}-\mathrm{Hpg}_{\mathrm{m}}$-Phe-Tyr-propyl \\
\hline $\mathbf{y}_{7}^{+1}$ & 944.4042 & 944.421 & 17.7 & Tyr-Asn- ${ }^{2} \mathrm{H}_{2} \mathrm{Hpg}_{\mathrm{m}}-\mathrm{Hpg}$ m-Phe-Tyr-propyl \\
\hline
\end{tabular}


Table S28. HR-MS/MS for substrate S16, with isotopically labelled AA3 (ortho- ${ }^{2} \mathrm{H}_{2}-\mathrm{D}-\mathrm{Hpg}$ ), and products obtained upon reaction with OxyB (-2 Da products, S18, S20; -3Da product, S17, S19). HR-MS/MS for substrate S16, containing labelled AA3 (ortho- ${ }^{2} \mathrm{H}_{2}-\mathrm{D}-\mathrm{Hpg} 4$ )

\begin{tabular}{|c|c|c|c|c|}
\hline $\begin{array}{c}\text { Charge } \\
\text { State } \\
\end{array}$ & $\begin{array}{c}\text { Calculated } \\
\mathbf{m} / \mathbf{z}\end{array}$ & $\begin{array}{c}\text { Observed } \\
\mathbf{m} / \mathbf{z} \\
\end{array}$ & $\Delta$ ppm & Sequence \\
\hline $\mathbf{b}_{1}^{+1}$ & 128.1075 & 128.1096 & 16.3 & MeLeu \\
\hline $\mathbf{b}_{2}{ }^{+1}$ & 291.1709 & 291.1769 & 20.6 & MeLeu-Tyr \\
\hline $\mathbf{b}_{3}{ }^{+1}$ & 405.2138 & 405.2224 & 21.2 & MeLeu-Tyr-Asn \\
\hline $\mathbf{b}_{4}^{+1}$ & 554.2615 & 554.2733 & 21.2 & MeLeu-Tyr-Asn-Hpg \\
\hline$b_{5}^{+1}$ & 705.3217 & 705.3352 & 19.1 & MeLeu-Tyr-Asn-Hpg- ${ }^{2} \mathrm{H}_{2} \mathrm{Hpg}$ \\
\hline $\mathbf{b}_{6}{ }^{+1}$ & 852.3901 & 852.4076 & 20.5 & MeLeu-Tyr-Asn-Hpg- ${ }^{2} \mathrm{H}_{2} \mathrm{Hpg}-\mathrm{Phe}$ \\
\hline $\mathbf{b}_{7}^{+1}$ & 1015.453 & 1015.474 & 19.9 & MeLeu-Tyr-Asn-Hpg- ${ }^{2} \mathrm{H}_{2} \mathrm{Hpg}$-Phe-Tyr \\
\hline $\mathrm{y}_{2}{ }^{+1}$ & 223.1426 & 223.149 & 24.1 & Tyr-propyl \\
\hline $\mathbf{y}_{3}{ }^{+1}$ & 370.212 & 370.2213 & 25.1 & Phe-Tyr-propyl \\
\hline $\mathbf{y}_{4}^{+1}$ & 521.2722 & 521.2822 & 19.1 & ${ }^{2} \mathrm{H}_{2} \mathrm{Hpg}$-Phe-Tyr-propyl \\
\hline$y_{5}+1$ & 670.3199 & 670.3337 & 20.5 & $\mathrm{Hpg}-{ }^{2} \mathrm{H}_{2} \mathrm{Hpg}$-Phe-Tyr-propyl \\
\hline $\mathbf{y}_{6}{ }^{+1}$ & 784.3628 & 784.3782 & 19.6 & Asn-Hpg- ${ }^{2} \mathrm{H}_{2} \mathrm{Hpg}$-Phe-Tyr-propyl \\
\hline $\mathbf{y}_{7}^{+1}$ & 947.4261 & 947.4455 & 20.4 & Tyr-Asn-Hpg- ${ }^{2} \mathrm{H}_{2} \mathrm{Hpg}$-Phe-Tyr-propyl \\
\hline
\end{tabular}

HR-MS/MS for -2 Da products S18, S20 containing labelled AA3 (ortho- $\left.{ }^{2} \mathrm{H}_{2}-\mathrm{D}-\mathrm{Hpg} 4\right)$

\begin{tabular}{|c|c|c|c|c|}
\hline $\begin{array}{c}\text { Charge } \\
\text { State } \\
\end{array}$ & $\begin{array}{c}\text { Calculated } \\
\mathrm{m} / \mathrm{z}\end{array}$ & $\begin{array}{c}\text { Observed } \\
\mathbf{m} / \mathbf{z}\end{array}$ & $\Delta$ ppm & Sequence \\
\hline $\mathbf{b}_{2}{ }^{+1}$ & 291.1709 & 291.1766 & 19.5 & MeLeu-Tyr \\
\hline $\mathbf{b}_{3}{ }^{+1}$ & 405.2138 & 405.2214 & 18.7 & MeLeu-Tyr-Asn \\
\hline $\mathbf{b}_{4}^{+1}$ & 554.2615 & 554.2719 & 18.7 & MeLeu-Tyr-Asn-Hpg \\
\hline$b_{6}+1$ & 850.3843 & 850.3745 & 11.5 & MeLeu-Tyr-Asn-Hpg- ${ }^{2} \mathrm{H}_{2} \mathrm{Hpg}$-Phe \\
\hline $\mathbf{b}_{7}^{+1}$ & 1013.4549 & 1013.4378 & 16.8 & MeLeu-Tyr-Asn-Hpg- ${ }^{2} \mathrm{H}_{2} \mathrm{Hpg}$-Phe-Tyr \\
\hline $\mathrm{y}_{3}{ }^{+1}$ & 370.212 & 370.2211 & 24.5 & Tyr-propyl \\
\hline $\mathbf{y}^{+1}$ & 519.2566 & 519.2431 & 25.9 & ${ }^{2} \mathrm{H}_{2} \mathrm{Hpg}$-Phe-Tyr-propyl \\
\hline $\mathbf{y}_{5}^{+1}$ & 668.3042 & 668.3176 & 20.1 & $\mathrm{Hpg}^{2}{ }^{2} \mathrm{H}_{2} \mathrm{Hpg}$-Phe-Tyr-propyl \\
\hline $\mathbf{y}_{6}{ }^{+1}$ & 782.3472 & 782.3624 & 19.4 & Asn-Hpg- ${ }^{2} \mathrm{H}_{2} \mathrm{Hpg}$-Phe-Tyr-propyl \\
\hline $\mathbf{y}_{7}^{+1}$ & 945.4105 & 945.428 & 18.5 & Tyr-Asn-Hpg- ${ }^{2} \mathrm{H}_{2} \mathrm{Hpg}-\mathrm{Phe}-\mathrm{Tyr}-$ propyl \\
\hline
\end{tabular}

HR-MS/MS for -3 Da products $\boldsymbol{S} 17, \boldsymbol{S} 19$ containing labelled AA3 (ortho- ${ }^{2} \mathrm{H}_{2}-\mathrm{D}-\mathrm{Hpg} 4$ )

\begin{tabular}{|c|c|c|c|c|}
\hline $\begin{array}{c}\text { Charge } \\
\text { State } \\
\end{array}$ & $\begin{array}{c}\text { Calculated } \\
\mathrm{m} / \mathrm{z}\end{array}$ & $\begin{array}{c}\text { Observed } \\
\mathbf{m} / \mathbf{z}\end{array}$ & $\Delta$ ppm & Sequence \\
\hline $\mathbf{b}_{2}{ }^{+1}$ & 291.1709 & 291.1756 & 16.1 & MeLeu-Tyr \\
\hline $\mathbf{b}_{3}{ }^{+1}$ & 405.2138 & 405.219 & 12.8 & MeLeu-Tyr-Asn \\
\hline $\mathrm{b}^{+1}$ & 554.2615 & 554.269 & 13.5 & MeLeu-Tyr-Asn-Hpg \\
\hline $\mathbf{b s}^{+1}$ & 702.2998 & 702.3038 & 5.6 & MeLeu-Tyr-Asn-Hpg- ${ }^{2} \mathrm{H}_{2} \mathrm{Hpg}$ \\
\hline$b_{6}{ }^{+1}$ & 849.3642 & 849.3741 & 6.9 & MeLeu-Tyr-Asn-Hpg- ${ }^{2} \mathrm{H}_{2} \mathrm{Hpg}$-Phe \\
\hline $\mathbf{b}_{7}^{+1}$ & 1012.432 & 1012.447 & 15.2 & MeLeu-Tyr-Asn-Hpg- ${ }^{2} \mathrm{H}_{2} \mathrm{Hpg}-\mathrm{Phe}-\mathrm{Tyr}$ \\
\hline $\mathrm{y}_{2}{ }^{+1}$ & 223.1436 & 223.1436 & 24.6 & Tyr-propyl \\
\hline $\mathbf{y s}^{+1}$ & 667.298 & 667.307 & 13.4 & Hpg- ${ }^{2} \mathrm{H}_{2} \mathrm{Hpg}$-Phe-Tyr-propyl \\
\hline $\mathbf{y}_{6}{ }^{+1}$ & 781.3409 & 781.3618 & 26.7 & Asn-Hpg- ${ }^{2} \mathrm{H}_{2} \mathrm{Hpg}$-Phe-Tyr-propyl \\
\hline $\mathrm{y}_{7}^{+1}$ & 944.4042 & 944.421 & 17.7 & Tyr-Asn-Hpg- ${ }^{2} \mathrm{H}_{2} \mathrm{Hpg}$-Phe-Tyr-propyl \\
\hline
\end{tabular}


Table S29. NMR assignments for 32 in $\left(\mathrm{CD}_{3}\right)_{2} \mathrm{SO}$ from $\mathrm{C}$ - to N-terminus. The structure and number scheme for the compound is shown below the table.

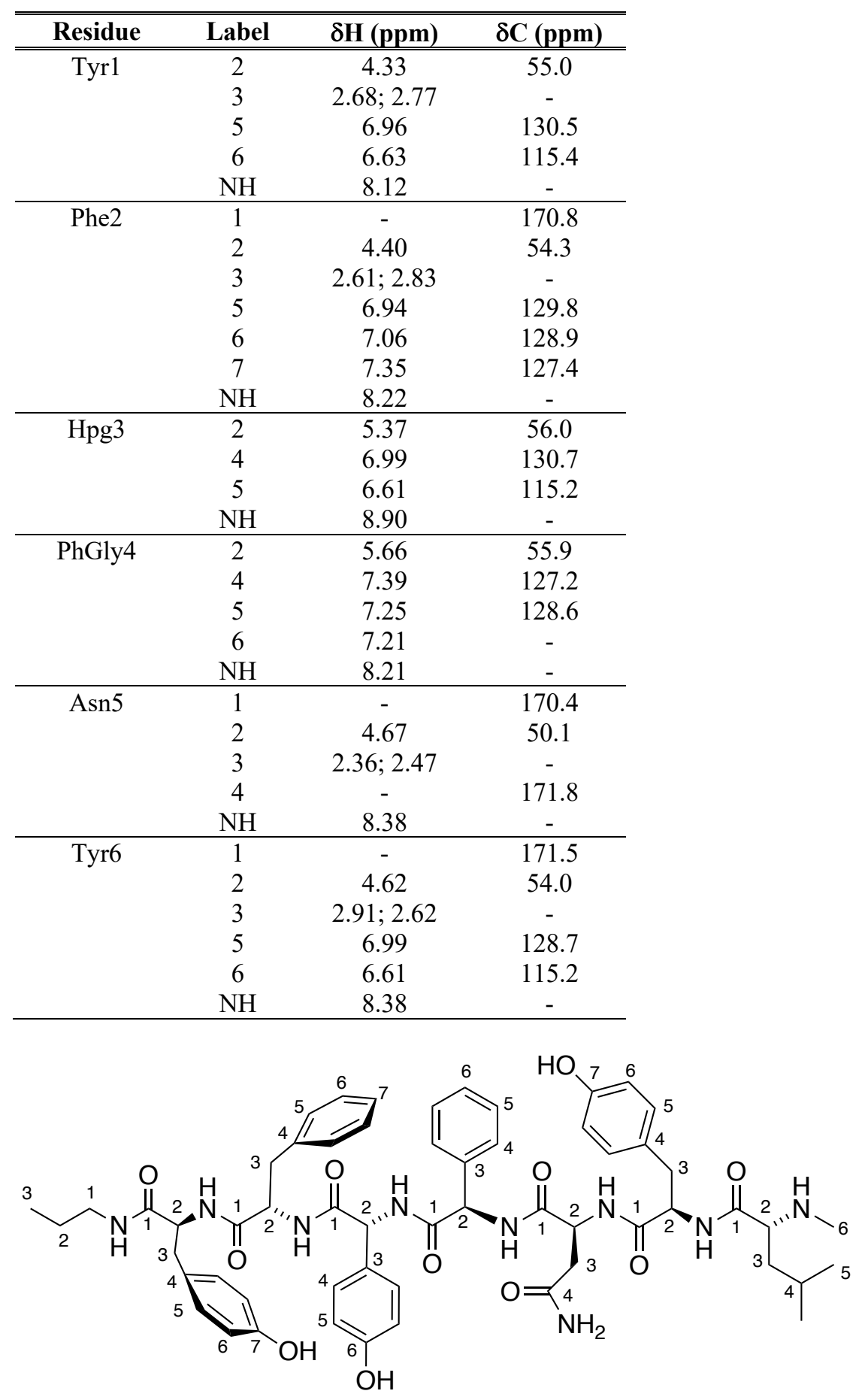


Table S30. NMR assignments for 33 in $\left(\mathrm{CD}_{3}\right)_{2} \mathrm{SO}$ from $\mathrm{C}$ - to N-terminus. The structure and number scheme for the compound is shown below the table.

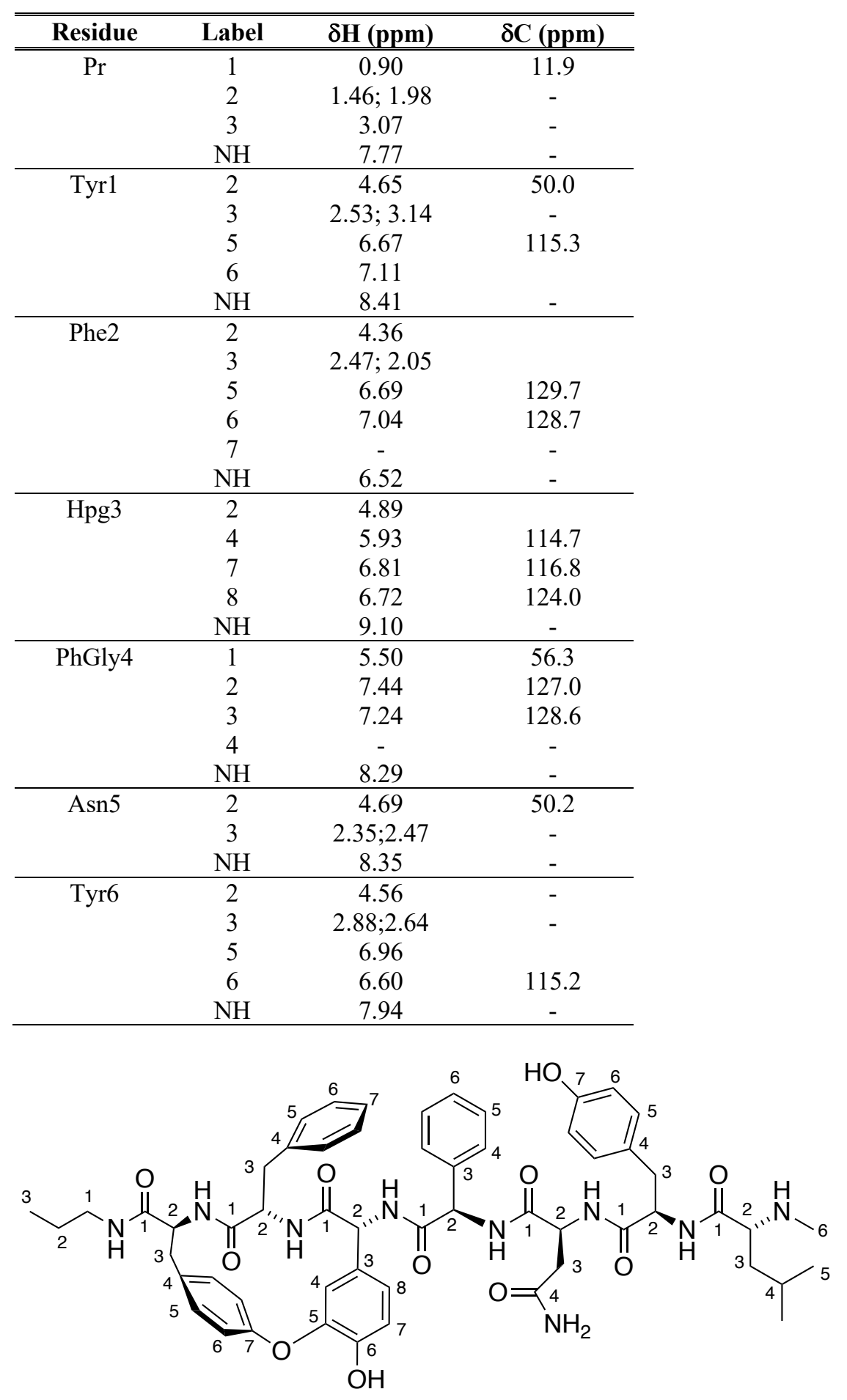


Table S31. HR-MS data for substrates and products of OxyB enzymatic reactions to generate analogs with different substituents. Sequence of peptides shown is (L-Tyr1)-AA2-AA3-AA4-(LAsn5)-(D-Tyr6)-(N-Me-D-Leu7).

\begin{tabular}{|c|c|c|c|c|c|c|c|}
\hline Compound & AA2 & $\mathbf{A A 3}$ & AA4 & $\begin{array}{c}\text { Charge } \\
\text { State } \\
\end{array}$ & $\begin{array}{c}\text { Calculated } \\
\text { mass }\end{array}$ & $\begin{array}{c}\text { Observed } \\
\text { mass }\end{array}$ & $\Delta p p m$ \\
\hline 34 & 4-Me-L-Phe & D-Hpg & D-Hpg & {$[\mathrm{M}+\mathrm{H}]^{+}$} & 1086.5295 & 1086.52915 & 0.3 \\
\hline 35 & 4-Me-L-Phe & D-Hpg & D-Hpg & {$[\mathrm{M}+\mathrm{H}]^{+}$} & 1084.5138 & 1084.51221 & 1.4 \\
\hline- & 4-Me-L-Phe & D-Hpg & ${ }^{2} \mathrm{H}_{2}-\mathrm{D}-\mathrm{Hpg}$ & {$[\mathrm{M}+\mathrm{H}]^{+}$} & 1088.542 & 1088.54744 & 4.9 \\
\hline 36 & 4-Me-L-Phe & D-Hpg & ${ }^{2} \mathrm{H}_{2}-\mathrm{D}-\mathrm{Hpg}$ & {$[\mathrm{M}+\mathrm{H}]^{+}$} & 1085.5201 & 1085.52446 & 4.0 \\
\hline- & 4-CD3-L-Phe & D-Hpg & D-Hpg & {$[\mathrm{M}+\mathrm{H}]^{+}$} & 1089.5483 & 1089.5578 & 8.7 \\
\hline 37 & 4- $\mathrm{CD}_{3}$-L-Phe & D-Hpg & D-Hpg & {$[\mathrm{M}+\mathrm{H}]^{+}$} & 1087.5327 & 1087.54094 & 7.5 \\
\hline- & 4-CD3-L-Phe & D-Hpg & ${ }^{2} \mathrm{H}_{2}$-D-Hpg & {$[\mathrm{M}+\mathrm{H}]^{+}$} & 1091.5609 & 1091.57447 & 12.4 \\
\hline 38 & 4-CD3-L-Phe & D-Hpg & ${ }^{2} \mathrm{H}_{2}$-D-Hpg & {$[\mathrm{M}+\mathrm{H}]^{+}$} & 1088.539 & 1088.5504 & 10.4 \\
\hline 39 & 4-Me-L-Phe & D-Hpg & D-PhGly & {$[\mathrm{M}+\mathrm{H}]^{+}$} & 1070.5346 & 1070.53765 & 2.8 \\
\hline 40 & 4-Me-L-Phe & D-Hpg & D-PhGly & {$[\mathrm{M}+\mathrm{H}]^{+}$} & 1068.5189 & 1068.52095 & 1.9 \\
\hline- & 4-Me-L-Phe & ${ }^{2} \mathrm{H}_{2}-\mathrm{D}-\mathrm{Hpg}$ & D-PhGly & {$[\mathrm{M}+\mathrm{H}]^{+}$} & 1072.5471 & 1072.56038 & 12.3 \\
\hline 41 & 4-Me-L-Phe & ${ }^{2} \mathrm{H}_{2}-\mathrm{D}-\mathrm{Hpg}$ & D-PhGly & {$[\mathrm{M}+\mathrm{H}]^{+}$} & 1069.5252 & 1069.54123 & 14.9 \\
\hline- & 4-CD3-L-Phe & D-Hpg & D-PhGly & {$[\mathrm{M}+\mathrm{H}]^{+}$} & 1073.5534 & 1073.56881 & 14.3 \\
\hline 42 & 4-CD 3 -L-Phe & D-Hpg & D-PhGly & {$[\mathrm{M}+\mathrm{H}]^{+}$} & 1071.5378 & 1071.55087 & 12.1 \\
\hline 43 & 4-NH2-L-Phe & D-Hpg & D-Hpg & {$[\mathrm{M}+\mathrm{H}]^{+}$} & 1087.52466 & 1087.5192 & 5.0 \\
\hline 44 & 4-NH $-\mathrm{NH}_{2}$-Phe & D-Hpg & D-Hpg & {$[\mathrm{M}+\mathrm{H}]^{+}$} & 1085.5091 & 1085.50697 & 1.9 \\
\hline- & 4-NH $-\mathrm{NH}_{2}-\mathrm{Phe}$ & D-Hpg & ${ }^{2} \mathrm{H}_{2}$-D-Hpg & {$[\mathrm{M}+\mathrm{H}]^{+}$} & 1089.5375 & 1089.54058 & 2.8 \\
\hline 45 & 4-NH $-\mathrm{NH}_{2}$-Phe & D-Hpg & ${ }^{2} \mathrm{H}_{2}$-D-Hpg & {$[\mathrm{M}+\mathrm{H}]^{+}$} & 1086.5154 & 1086.52363 & 7.5 \\
\hline 46 & 4-NH2-L-Phe & D-Hpg & D-PhGly & {$[\mathrm{M}+\mathrm{H}]^{+}$} & 1071.5298 & 1071.53728 & 6.9 \\
\hline 47 & 4-NH2-L-Phe & D-Hpg & D-PhGly & {$[\mathrm{M}+\mathrm{H}]^{+}$} & 1069.5142 & 1069.52277 & 8.0 \\
\hline
\end{tabular}


Table S32. HR-MS/MS data for starting material 34 (AA2 = 4-Me-L-Phe, AA4 = L-Hpg) and product 35.

$H R-M S / M S$ for starting material $34(A A 2=4-M e-L-P h e, A A 4=L-H p g)$

\begin{tabular}{ccccl}
\hline $\begin{array}{c}\text { Charge } \\
\text { State }\end{array}$ & $\begin{array}{c}\text { Calculated } \\
\mathbf{m} / \mathbf{z}\end{array}$ & $\begin{array}{c}\text { Observed } \\
\mathbf{m} / \mathbf{z}\end{array}$ & $\boldsymbol{\Delta} \mathbf{p p m}$ & \multicolumn{1}{c}{ Sequence } \\
\hline $\mathbf{b}_{2}{ }^{+1}$ & 291.1709 & 291.1702 & 2.4 & MeLeu-Tyr \\
$\mathbf{b}_{3}{ }^{+1}$ & 405.2138 & 405.2131 & 1.7 & MeLeu-Tyr-Asn \\
$\mathbf{b}_{4}{ }^{+1}$ & 554.2615 & 554.2608 & 1.2 & MeLeu-Tyr-Asn-Hpg \\
$\mathbf{b}_{5}{ }^{+1}$ & 703.3092 & 703.3081 & 1.5 & MeLeu-Tyr-Asn-Hpg-Hpg \\
$\mathbf{b}_{6}{ }^{+1}$ & 864.3932 & 864.3918 & 1.6 & MeLeu-Tyr-Asn-Hpg-Hpg-4MePhe \\
$\mathbf{b}_{7}{ }^{+1}$ & 1027.4565 & 1027.4565 & 1.6 & MeLeu-Tyr-Asn-Hpg-Hpg-4MePhe-Tyr \\
\hline $\mathbf{y}_{\mathbf{2}}{ }^{+1}$ & 223.1436 & 223.1438 & 0.8 & Tyr-propyl \\
$\mathbf{y}_{3}{ }^{+1}$ & 384.2276 & 384.2278 & 0.5 & 4MePhe -Tyr-propyl \\
$\mathbf{y}_{4}{ }^{+1}$ & 533.2853 & 533.2747 & 1.1 & Hpg-4MePhe -Tyr-propyl \\
$\mathbf{y}_{5}{ }^{+1}$ & 682.323 & 682.3229 & 0.1 & Hpg-Hpg-4MePhe -Tyr-propyl \\
$\mathbf{y}_{\mathbf{6}}{ }^{+1}$ & 796.3659 & 796.3654 & 0.6 & Asn-Hpg-Hpg-4MePhe -Tyr-propyl \\
$\mathbf{y}_{\mathbf{1}}{ }^{+1}$ & 959.4292 & 959.4286 & 0.6 & Tyr-Asn-Hpg-Hpg-4MePhe -Tyr-propyl \\
\hline
\end{tabular}

HR-MS/MS for product $35(A A 2=4-M e-L-P h e, A A 4=L-H p g)$

\begin{tabular}{|c|c|c|c|c|}
\hline $\begin{array}{c}\text { Charge } \\
\text { State }\end{array}$ & $\begin{array}{c}\text { Calculated } \\
\mathrm{m} / \mathrm{z}\end{array}$ & $\begin{array}{c}\text { Observed } \\
\mathbf{m} / \mathbf{z}\end{array}$ & $\Delta$ ppm & Sequence \\
\hline $\mathbf{b}_{2}{ }^{+1}$ & 291.1709 & 291.1701 & 2.7 & MeLeu-Tyr \\
\hline $\mathbf{b}_{3}{ }^{+1}$ & 405.2138 & 405.2128 & 2.4 & MeLeu-Tyr-Asn \\
\hline $\mathbf{b}_{7}^{+1}$ & 1025.4409 & 1025.4397 & 1.1 & MeLeu-Tyr-Asn-Hpg \\
\hline$y_{2}{ }^{+1}$ & 223.1436 & 223.1426 & 4.5 & Tyr-propyl \\
\hline$y_{5}^{+1}$ & 680.3073 & 680.3061 & 1.7 & $\mathrm{Hpg}_{\mathrm{m}}$-Hpg-4MePhe $\mathrm{m}_{\mathrm{m}}$-Tyr-propyl \\
\hline $\mathbf{y}_{6}^{+1}$ & 794.3503 & 794.3415 & 1.3 & Asn-Hpg - Hpg-4MePhe ${ }_{m}$-Tyr-propyl \\
\hline$y_{7}^{+1}$ & 957.4136 & 957.4141 & 0.5 & Tyr-Asn-Hpg ${ }_{m}-H p g-4 M e P h e_{m}$-Tyr-propyl \\
\hline
\end{tabular}


Table S33. HR-MS/MS data for starting material AA2 $=4-\mathrm{Me}-\mathrm{L}-\mathrm{Phe}$ and AA4 $=$ ortho- ${ }^{2} \mathrm{H}_{2}-\mathrm{D}-$

Hpg and -3 Da product upon reaction with OxyB (36).

HR-MS/MS for starting material AA2 =4-Me-L-Phe and AA4 =ortho- ${ }^{2} H_{2}-D-H p g$

\begin{tabular}{|c|c|c|c|c|}
\hline $\begin{array}{c}\text { Charge } \\
\text { State }\end{array}$ & $\begin{array}{c}\text { Calculated } \\
\mathbf{m} / \mathbf{z}\end{array}$ & $\begin{array}{c}\text { Observed } \\
\mathbf{m} / \mathbf{z}\end{array}$ & $\Delta$ ppm & Sequence \\
\hline $\mathbf{b}_{2}{ }^{+1}$ & 291.1709 & 291.1715 & 2.0 & MeLeu-Tyr \\
\hline $\mathbf{b}_{3}{ }^{+1}$ & 405.2138 & 405.2164 & 6.4 & MeLeu-Tyr-Asn \\
\hline $\mathbf{b}_{4}{ }^{+1}$ & 556.274 & 556.2773 & 5.9 & MeLeu-Tyr-Asn- ${ }^{2} \mathrm{H}_{2} \mathrm{Hpg}$ \\
\hline $\mathbf{b}_{5}{ }^{+1}$ & 705.3217 & 705.3217 & 0.8 & MeLeu-Tyr-Asn- ${ }^{2} \mathrm{H}_{2} \mathrm{Hpg}-\mathrm{Hpg}$ \\
\hline$b_{6}{ }^{+1}$ & 866.4058 & 866.4105 & 5.4 & MeLeu-Tyr-Asn- ${ }^{2} \mathrm{H}_{2} \mathrm{Hpg}-\mathrm{Hpg}-4 \mathrm{MePhe}$ \\
\hline $\mathbf{b}_{7}{ }^{+1}$ & 1029.4691 & 1029.473 & 3.7 & MeLeu-Tyr-Asn- ${ }^{2} \mathrm{H}_{2} \mathrm{Hpg}-\mathrm{Hpg}-4 \mathrm{MePhe}-\mathrm{Tyr}$ \\
\hline $\mathbf{y}_{2}{ }^{+1}$ & 223.1436 & 223.1418 & 7.8 & Tyr-propyl \\
\hline $\mathbf{y}_{3}{ }^{+1}$ & 384.2276 & 384.2282 & 1.5 & 4MePhe-Tyr-propyl \\
\hline $\mathbf{y}_{4}^{+1}$ & 533.2753 & 533.2786 & 6.2 & Hpg-4MePhe-Tyr-propyl \\
\hline $\mathbf{y}_{5}^{+1}$ & 684.3355 & 684.3366 & 1.6 & ${ }^{2} \mathrm{H}_{2} \mathrm{Hpg}$-Hpg-4MePhe-Tyr-propyl \\
\hline$y_{6}{ }^{+1}$ & 798.3785 & 798.3823 & 4.8 & Asn- ${ }^{2} \mathrm{H}_{2} \mathrm{Hpg}-\mathrm{Hpg}-4 \mathrm{MePhe}-\mathrm{Tyr}-$ propyl \\
\hline $\mathrm{y}_{7}+1$ & 961.4418 & 961.4447 & 3.0 & 4MePhe-Asn- ${ }^{2} \mathrm{H}_{2} \mathrm{Hpg}$-Hpg-4MePhe-Tyr-propyl \\
\hline
\end{tabular}

HR-MS/MS for product 36

\begin{tabular}{|c|c|c|c|c|}
\hline $\begin{array}{c}\text { Charge } \\
\text { State }\end{array}$ & $\begin{array}{c}\text { Calculated } \\
\mathbf{m} / \mathbf{z}\end{array}$ & $\begin{array}{c}\text { Observed } \\
\mathbf{m} / \mathbf{z}\end{array}$ & $\Delta p p m$ & Sequence \\
\hline $\mathbf{b}_{3}{ }^{+1}$ & 405.2138 & 405.2161 & 5.7 & MeLeu-Tyr-Asn \\
\hline$b_{6}{ }^{+1}$ & 864.3901 & 864.3952 & 5.9 & MeLeu-Tyr-Asn- ${ }^{2} \mathrm{H}_{2} \mathrm{Hpg}_{\mathrm{m}}-\mathrm{Hpg}-4 \mathrm{MePhe}-\mathrm{myr}$ \\
\hline $\mathbf{b}_{7}^{+1}$ & 1026.4472 & 1026.4472 & 4.2 & MeLeu-Tyr-Asn- ${ }^{2} \mathrm{H}_{2} \mathrm{Hpg}_{\mathrm{m}}-\mathrm{Hpg}-4 \mathrm{MePhe} \mathrm{e}_{\mathrm{m}}-\mathrm{Tyr}$ \\
\hline $\mathrm{y}_{6}{ }^{+1}$ & 795.3565 & 795.3448 & 14.6 & Asn- ${ }^{2} \mathrm{H}_{2} \mathrm{Hpg}_{\mathrm{m}}-\mathrm{Hpg}-4 \mathrm{MeTyr}_{\mathrm{m}}$-Tyr-propyl \\
\hline $\mathbf{y}_{7}^{+1}$ & 958.4199 & 958.4166 & 3.4 & Tyr-Asn- ${ }^{2} \mathrm{H}_{2} \mathrm{Hpg}_{\mathrm{m}}-\mathrm{Hpg}-4 \mathrm{MeTyr_{m } - \mathrm { Tyr } - \text { propyl }}$ \\
\hline
\end{tabular}


Table S34. HR-MS/MS data for starting material AA2 $=4-\mathrm{CD}_{3}-\mathrm{L}-\mathrm{Ph}$ and AA4 = D-Hpg and -2 Da product upon reaction with OxyB (37).

$H R-M S / M S$ for starting material $A A 2=4-C D_{3}-L-P h e$ and $A A 4=D-H p g$

\begin{tabular}{|c|c|c|c|c|}
\hline $\begin{array}{c}\text { Charge } \\
\text { State }\end{array}$ & $\begin{array}{c}\text { Calculated } \\
\mathrm{m} / \mathrm{z}\end{array}$ & $\begin{array}{c}\text { Observed } \\
\mathbf{m} / \mathbf{z}\end{array}$ & $\Delta$ ppm & Sequence \\
\hline $\mathbf{b}_{2}^{+1}$ & 291.1709 & 291.1684 & 8.5 & MeLeu-Tyr \\
\hline $\mathbf{b}_{3}{ }^{+1}$ & 405.2138 & 405.2099 & 9.5 & MeLeu-Tyr-Asn \\
\hline $\mathbf{b}_{4}^{+1}$ & 554.2615 & 554.2563 & 9.2 & MeLeu-Tyr-Asn-Hpg \\
\hline $\mathbf{b}_{5}^{+1}$ & 703.3092 & 703.3029 & 8.8 & MeLeu-Tyr-Asn-Hpg-Hpg \\
\hline $\mathbf{b}_{6}+1$ & 867.412 & 867.4037 & 9.4 & MeLeu-Tyr-Asn-Hpg-Hpg-4CD ${ }_{3}$ Phe \\
\hline $\mathbf{b}_{7}{ }^{+1}$ & 1030.4754 & 1030.4601 & 14.8 & MeLeu-Tyr-Asn-Hpg-Hpg-4CD ${ }_{3}$ Phe-Tyr \\
\hline $\mathrm{y}_{2}+1$ & 223.1436 & 223.143 & 2.6 & Tyr-propyl \\
\hline $\mathbf{y 3}^{+1}$ & 387.2464 & 387.2433 & 7.9 & $4 \mathrm{CD}_{3}$ Phe-Tyr-propyl \\
\hline $\mathbf{y}_{4}^{+1}$ & 536.2941 & 536.2843 & 18.2 & Hpg-4CD 3 Phe-Tyr-propyl \\
\hline $\mathbf{y}_{5}^{+1}$ & 685.3418 & 685.3333 & 12.3 & Hpg-Hpg-4CD 3 Phe-Tyr-propyl \\
\hline $\mathrm{y}_{7}^{+1}$ & 962.4481 & 962.4399 & 8.4 & Asn-Hpg-Hpg-4CD 3 Phe-Tyr-propyl \\
\hline
\end{tabular}

HR-MS/MS for product 37

\begin{tabular}{|c|c|c|c|c|}
\hline $\begin{array}{c}\text { Charge } \\
\text { State }\end{array}$ & $\begin{array}{c}\text { Calculated } \\
\mathbf{m} / \mathbf{z}\end{array}$ & $\begin{array}{c}\text { Observed } \\
\mathrm{m} / \mathrm{z}\end{array}$ & $\Delta p p m$ & Sequence \\
\hline $\mathbf{b}_{2}{ }^{+1}$ & 291.1709 & 291.1657 & 8.3 & MeLeu-Tyr \\
\hline $\mathrm{b}^{+1}$ & 405.2138 & 405.2091 & 11.4 & MeLeu-Tyr-Asn \\
\hline $\mathrm{b}_{6}{ }^{+1}$ & 865.3964 & 865.3881 & 9.5 & MeLeu-Tyr-Asn-Hpgm-Hpg-4CD ${ }_{3}$ Phe \\
\hline $\mathrm{y}_{5}^{+1}$ & 683.3262 & 683.3228 & 4.9 & Asn-Hpg ${ }_{m}-H p g-4 \mathrm{CD}_{3}$ Phe-Tyr-propyl \\
\hline
\end{tabular}


Table S35. HR-MS/MS data for starting material AA2 $=4-\mathrm{CD}_{3}-\mathrm{L}-\mathrm{Phe}$ and AA4 $=$ ortho- ${ }^{2} \mathrm{H}_{2}-\mathrm{D}-$ Hpg and -3 Da product upon reaction with OxyB (38).

$H R-M S / M S$ for starting material $A A 2=4-C D_{3}-L-P h e$ and $A A 4=$ ortho $^{2} \mathrm{H}_{2}-\mathrm{D}-\mathrm{Hpg}$

\begin{tabular}{|c|c|c|c|c|}
\hline $\begin{array}{c}\text { Charge } \\
\text { State }\end{array}$ & $\begin{array}{c}\text { Calculated } \\
\mathrm{m} / \mathrm{z}\end{array}$ & $\begin{array}{c}\text { Observed } \\
\mathbf{m} / \mathbf{z} \\
\end{array}$ & $\Delta \mathrm{ppm}$ & Sequence \\
\hline $\mathbf{b}_{1}{ }^{+1}$ & 128.1075 & 128.1075 & 14.0 & MeLeu \\
\hline $\mathbf{b}_{2}{ }^{+1}$ & 291.1709 & 291.1677 & 10.7 & MeLeu-Tyr \\
\hline $\mathbf{b}_{3}{ }^{+1}$ & 405.2138 & 405.2092 & 11.2 & MeLeu-Tyr-Asn \\
\hline $\mathbf{b}_{4}^{+1}$ & 556.274 & 556.2674 & 11.8 & MeLeu-Tyr-Asn- ${ }^{2} \mathrm{H}_{2} \mathrm{Hpg}$ \\
\hline$b_{5}{ }^{+1}$ & 705.3217 & 705.3126 & 12.8 & MeLeu-Tyr-Asn- ${ }^{2} \mathrm{H}_{2} \mathrm{Hpg}-\mathrm{Hpg}$ \\
\hline $\mathbf{b}_{6}{ }^{+1}$ & 869.4246 & 869.4127 & 13.6 & MeLeu-Tyr-Asn- ${ }^{2} \mathrm{H}_{2} \mathrm{Hpg}-\mathrm{Hpg}-4 \mathrm{CD}_{3} \mathrm{Phe}$ \\
\hline $\mathbf{b}_{7}^{+1}$ & 1032.4879 & 1032.4657 & 21.5 & MeLeu-Tyr-Asn- ${ }^{2} \mathrm{H}_{2} \mathrm{Hpg}-\mathrm{Hpg}-4 \mathrm{CD}_{3} \mathrm{Phe}-\mathrm{Tyr}$ \\
\hline $\mathbf{y}_{2}^{+1}$ & 223.1436 & 223.1428 & 3.5 & Tyr-propyl \\
\hline $\mathbf{y}_{3}{ }^{+1}$ & 387.2464 & 387.2405 & 15.2 & $4 \mathrm{CD}_{3}$ Phe-Tyr-propyl \\
\hline $\mathbf{y}^{+1}$ & 536.2941 & 536.3021 & 14.9 & Hpg-4CD 3 Phe-Tyr-propyl \\
\hline $\mathbf{y}_{5}^{+1}$ & 687.3544 & 687.3403 & 20.4 & ${ }^{2} \mathrm{H}_{2} \mathrm{Hpg}-\mathrm{Hpg}-4 \mathrm{CD}_{3}$ Phe-Tyr-propyl \\
\hline $\mathbf{y}_{7}^{+1}$ & 964.4606 & 964.4409 & 21.2 & Asn- ${ }^{2} \mathrm{H}_{2} \mathrm{Hpg}-\mathrm{Hpg}-4 \mathrm{CD}_{3}$ Phe-Tyr-propyl \\
\hline
\end{tabular}

HR-MS/MS for product 38

\begin{tabular}{ccccl}
\hline $\begin{array}{c}\text { Charge } \\
\text { State }\end{array}$ & $\begin{array}{c}\text { Calculated } \\
\mathbf{m} / \mathbf{z}\end{array}$ & $\begin{array}{c}\text { Observed } \\
\mathbf{m} / \mathbf{z}\end{array}$ & \multicolumn{1}{|c|}{ ppm } & \multicolumn{1}{c}{ Sequence } \\
\hline $\mathbf{b}^{+1}$ & 291.1709 & 291.1657 & 17.5 & MeLeu-Tyr \\
$\mathbf{b}_{3}{ }^{+1}$ & 405.2138 & 405.2051 & 21.3 & MeLeu-Tyr-Asn \\
\hline $\mathbf{y}_{\mathbf{6}}{ }^{+1}$ & 798.3754 & 798.3901 & 18.4 & \multicolumn{2}{c}{ Asn- $^{2} \mathrm{H}_{2} \mathrm{Hpg}_{\mathrm{m}}-\mathrm{Hpg}-4 \mathrm{CD}_{3} \mathrm{Tyr}_{\mathrm{m}}-\mathrm{Tyr}-$ propyl } \\
\hline
\end{tabular}


Table S36. HR-MS/MS data for starting material AA2 = 4-Me-L-Phe and AA4 = D-PhGly (39) and -2 Da product upon reaction with OxyB (40).

HR-MS/MS for starting material 39 (AA2 =4-Me-L-Phe and AA4 =D-PhGly)

\begin{tabular}{|c|c|c|c|c|}
\hline $\begin{array}{c}\text { Charge } \\
\text { State }\end{array}$ & $\begin{array}{c}\text { Calculated } \\
\mathbf{m} / \mathbf{z}\end{array}$ & $\begin{array}{c}\text { Observed } \\
\mathbf{m} / \mathbf{z}\end{array}$ & $\Delta p p m$ & Sequence \\
\hline $\mathbf{b}_{1}{ }^{+1}$ & 128.1075 & 128.107 & 3.9 & MeLeu \\
\hline $\mathbf{b}_{2}^{+1}$ & 291.1709 & 291.171 & 0.3 & MeLeu-Tyr \\
\hline $\mathbf{b}_{3}{ }^{+1}$ & 405.2138 & 405.2141 & 0.7 & MeLeu-Tyr-Asn \\
\hline $\mathbf{b}^{+1}$ & 538.2666 & 538.2674 & 1.4 & MeLeu-Tyr-Asn-PhGly \\
\hline$b_{5}+1$ & 687.2142 & 687.3147 & 0.7 & MeLeu-Tyr-Asn-PhGly-Hpg \\
\hline $\mathbf{b}_{6}{ }^{+1}$ & 848.3983 & 848.3987 & 0.5 & MeLeu-Tyr-Asn-PhGly-Hpg-4MePhe \\
\hline $\mathbf{b}_{7}{ }^{+1}$ & 1011.4616 & 1011.4618 & 0.2 & MeLeu-Tyr-Asn-PhGly-Hpg-4MePhe-Tyr \\
\hline $\mathbf{y}_{2}{ }^{+1}$ & 223.1436 & 223.1445 & 4.0 & Tyr-propyl \\
\hline$y_{3}{ }^{+1}$ & 384.2276 & 384.2287 & 2.8 & 4MePhe-Tyr-propyl \\
\hline $\mathrm{y}_{4}{ }^{+1}$ & 533.2753 & 533.2766 & 2.4 & Hpg-4MePhe-Tyr-propyl \\
\hline$y_{5}{ }^{+1}$ & 666.3281 & 666.3303 & 3.3 & PhGly-Hpg-4MePhe-Tyr-propyl \\
\hline$y_{6}{ }^{+1}$ & 780.371 & 780.3753 & 5.5 & Asn-PhGly-Hpg-4MePhe-Tyr-propyl \\
\hline $\mathbf{y}_{7}+1$ & 943.4343 & 943.4359 & 1.7 & Tyr-Asn-PhGly-Hpg-4MePhe-Tyr-propyl \\
\hline
\end{tabular}

HR-MS/MS for starting material 40 (AA2 =4-Me-L-Phe and AA4 =D-PhGly)

\begin{tabular}{|c|c|c|c|c|}
\hline $\begin{array}{l}\text { Charge } \\
\text { State }\end{array}$ & $\begin{array}{c}\text { Calculated } \\
\mathrm{m} / \mathrm{z}\end{array}$ & $\begin{array}{c}\text { Observed } \\
\mathbf{m} / \mathbf{z}\end{array}$ & $\Delta \mathrm{ppm}$ & Sequence \\
\hline $\mathbf{b}_{2}^{+1}$ & 291.1709 & 291.1703 & 2.0 & MeLeu-Tyr \\
\hline $\mathbf{b}_{3}{ }^{+1}$ & 405.2138 & 405.2137 & 0.2 & MeLeu-Tyr-Asn \\
\hline $\mathbf{b}_{4}{ }^{+1}$ & 538.2666 & 538.2666 & 1.6 & MeLeu-Tyr-Asn-PhGly \\
\hline $\mathbf{b}_{6}{ }^{+1}$ & 846.3827 & 846.3804 & 2.7 & MeLeu-Tyr-Asn-PhGly-Hpgm-4MePhem \\
\hline $\mathbf{b}_{7}^{+1}$ & 1009.446 & 1009.4438 & 2.1 & MeLeu-Tyr-Asn-PhGly-Hpg ${ }_{m}-4 \mathrm{MePhe}_{\mathrm{m}}-\mathrm{Tyr}$ \\
\hline $\mathrm{y}_{4}^{+1}$ & 531.2596 & 531.2564 & 6.0 & $\mathrm{Hpg}_{\mathrm{m}}-4 \mathrm{MePhe}_{\mathrm{m}}$-Tyr-propyl \\
\hline$y_{5}{ }^{+1}$ & 664.3124 & 664.3142 & 2.7 & PhGly-Hpg ${ }_{m}-4 \mathrm{MePhe}_{\mathrm{m}}$-Tyr-propyl \\
\hline $\mathrm{y}_{6}{ }^{+1}$ & 778.3553 & 778.3545 & 1.0 & Asn-PhGly-Hpg $\mathrm{m}_{\mathrm{m}}-4 \mathrm{MePhe}_{\mathrm{m}}$-Tyr-propyl \\
\hline $\mathbf{y}_{7}^{+1}$ & 941.4187 & 941.4202 & 1.5 & Tyr-Asn-PhGly-Hpg $\mathrm{m}_{\mathrm{m}}-4 \mathrm{MePhe}$-Tyr-propyl \\
\hline
\end{tabular}


Table S37. HR-MS/MS data for starting material with AA2 = 4-CD $3-\mathrm{L}-\mathrm{Phe}$ and AA4 = D-PhGly and -2 Da product upon reaction with OxyB (41).

HR-MS/MS for starting material AA2 =4-CD $-L-P h e$ and $A A 4=D-P h G l y$

\begin{tabular}{|c|c|c|c|c|}
\hline $\begin{array}{c}\text { Charge } \\
\text { State } \\
\end{array}$ & $\begin{array}{c}\text { Calculated } \\
\mathrm{m} / \mathrm{z} \\
\end{array}$ & $\begin{array}{c}\text { Observed } \\
\mathrm{m} / \mathrm{z} \\
\end{array}$ & $\Delta p p m$ & Sequence \\
\hline $\mathbf{b}_{1}^{+1}$ & 128.1075 & 128.1053 & 17.0 & MeLeu \\
\hline $\mathbf{b}_{2}^{+1}$ & 291.1709 & 291.1676 & 11.0 & MeLeu-Tyr \\
\hline $\mathbf{b}_{3}{ }^{+1}$ & 405.2138 & 405.2088 & 12.1 & MeLeu-Tyr-Asn \\
\hline $\mathbf{b}_{4}^{+1}$ & 538.2666 & 538.2594 & 13.2 & MeLeu-Tyr-Asn-PhGly \\
\hline $\mathbf{b 5}^{+1}$ & 687.2142 & 687.3068 & 10.7 & MeLeu-Tyr-Asn-PhGly-Hpg \\
\hline $\mathbf{b}_{6}{ }^{+1}$ & 851.4171 & 851.4063 & 12.6 & MeLeu-Tyr-Asn-PhGly-Hpg-4CD ${ }_{3}$ Phe \\
\hline $\mathbf{b}_{7}+1$ & 1014.4805 & 1014.4535 & 26.5 & MeLeu-Tyr-Asn-PhGly-Hpg-4CD 3 Phe-Tyr \\
\hline$y_{2}^{+1}$ & 223.1436 & 223.1436 & 5.6 & Tyr-propyl \\
\hline $\mathrm{y3}^{+1}$ & 387.2464 & 387.2419 & 11.3 & $4 \mathrm{CD}_{3}$ Phe-Tyr-propyl \\
\hline $\mathbf{y}_{4}^{+1}$ & 536.2941 & 536.2917 & 4.3 & Hpg-4CD ${ }_{3}$ Phe-Tyr-propyl \\
\hline $\mathbf{y}_{5}^{+1}$ & 669.3469 & 669.3436 & 4.8 & PhGly-Hpg-4CD ${ }_{3}$ PheTyr-propyl \\
\hline $\mathbf{y}_{6}^{+1}$ & 783.3898 & 783.3969 & 9.1 & Asn-PhGly-Hpg-4CD ${ }_{3}$ Phe-Tyr-propyl \\
\hline $\mathbf{y}_{7}+1$ & 946.4531 & 946.4325 & 21.7 & 4MePhe-Asn-PhGly-Hpg-4CD ${ }_{3}$ Phe-Tyr-propyl \\
\hline
\end{tabular}

HR-MS/MS for product 41

\begin{tabular}{ccccll}
\hline $\begin{array}{c}\text { Charge } \\
\text { State }\end{array}$ & $\begin{array}{c}\text { Calculated } \\
\mathbf{m} / \mathbf{z}\end{array}$ & $\begin{array}{c}\text { Observed } \\
\mathbf{m} / \mathbf{z}\end{array}$ & \multicolumn{1}{|c|}{$\mathbf{p p m}$} & Sequence \\
\hline $\mathbf{b}_{2}{ }^{+1}$ & 291.1709 & 291.1635 & 25.1 & MeLeu-Tyr & \\
$\mathbf{b}_{3}{ }^{+1}$ & 405.2138 & 405.2138 & 13.8 & MeLeu-Tyr-Asn & \\
\hline
\end{tabular}


Table S38. HR-MS/MS data for starting material containing 4-Me-L-Phe2, ortho- ${ }^{2} \mathrm{H}_{2}-\mathrm{D}-\mathrm{Hpg} 3$, D-PhGly4 and -3 Da product upon reaction with OxyB (42).

HR-MS/MS for starting material AA2 =4-Me-L-Phe; $A A 3=$ ortho- ${ }^{2} \mathrm{H}_{2}-D-H p g ; A A 4=D-P h G l y$

\begin{tabular}{|c|c|c|c|c|}
\hline $\begin{array}{c}\text { Charge } \\
\text { State } \\
\end{array}$ & $\begin{array}{c}\text { Calculated } \\
\mathrm{m} / \mathrm{z} \\
\end{array}$ & $\begin{array}{c}\text { Observed } \\
\mathbf{m} / \mathbf{z}\end{array}$ & $\Delta p p m$ & Sequence \\
\hline $\mathbf{b}_{2}{ }^{+1}$ & 291.1709 & 291.1740 & 10.8 & MeLeu-Tyr \\
\hline $\mathbf{b}_{3}+1$ & 405.2138 & 405.2138 & 5.5 & MeLeu-Tyr-Asn \\
\hline $\mathbf{b}_{4}^{+1}$ & 538.2666 & 538.2666 & 7.0 & MeLeu-Tyr-Asn-PhGly \\
\hline $\mathbf{b}_{5}^{+1}$ & 689.3317 & 689.3268 & 7.1 & MeLeu-Tyr-Asn-PhGly-Hpg \\
\hline $\mathbf{b}_{6}{ }^{+1}$ & 850.4109 & 850.4152 & 5.0 & MeLeu-Tyr-Asn-PhGly-Hpg-4MePhe \\
\hline $\mathbf{b}_{7}+\mathbf{1}$ & 1013.4742 & 1013.4642 & 9.8 & MeLeu-Tyr-Asn-PhGly-Hpg-4MePhe-Tyr \\
\hline$y_{2}^{+1}$ & 223.1436 & 223.1460 & 11.1 & Tyr-propyl \\
\hline $\mathbf{y}^{+1}$ & 384.2276 & 384.2316 & 10.5 & 4MePhe-Tyr-propyl \\
\hline $\mathbf{y}_{4}^{+1}$ & 533.2753 & 533.2766 & 2.4 & Hpg-4MePhe-Tyr-propyl \\
\hline $\mathbf{y}_{7}^{+1}$ & 945.4469 & 945.4468 & 0.0 & Tyr-Asn-PhGly-Hpg-4MePhe-Tyr-propyl \\
\hline
\end{tabular}

HR-MS/MS for product 42

\begin{tabular}{|c|c|c|c|c|}
\hline $\begin{array}{c}\text { Charge } \\
\text { State } \\
\end{array}$ & $\begin{array}{c}\text { Calculated } \\
\mathbf{m} / \mathbf{z}\end{array}$ & $\begin{array}{c}\text { Observed } \\
\mathbf{m} / \mathbf{z}\end{array}$ & $\Delta$ ppm & Sequence \\
\hline $\mathbf{b}_{2}{ }^{+1}$ & 291.1709 & 291.1724 & 5.2 & MeLeu-Tyr \\
\hline $\mathbf{b}_{3}{ }^{+1}$ & 405.2138 & 405.2166 & 7.0 & MeLeu-Tyr-Asn \\
\hline $\mathbf{b}_{4}^{+1}$ & 538.2666 & 538.2683 & 3.1 & MeLeu-Tyr-Asn-PhGly \\
\hline $\mathbf{b}_{6}{ }^{+1}$ & 847.3889 & 847.3803 & 10.0 & MeLeu-Tyr-Asn-PhGly-Hpg ${ }_{m}-4 \mathrm{MePhe}_{\mathrm{m}}$ \\
\hline $\mathbf{b}_{7}{ }^{+1}$ & 1010.4523 & 1010.4431 & 9.1 & MeLeu-Tyr-Asn-PhGly-Hpg ${ }_{m}-4$ MePhe $_{m}-$ Tyr \\
\hline $\mathbf{y}_{2}{ }^{+1}$ & 223.1436 & 223.1456 & 9.1 & Tyr-propyl \\
\hline $\mathbf{y}_{5}{ }^{+1}$ & 665.3187 & 665.3192 & 0.8 & PhGly-Hpg $-4 \mathrm{MePhe}_{\mathrm{m}}$-Tyr-propyl \\
\hline
\end{tabular}


Table S39. HR-MS/MS data for starting material AA2 = 4-NH2-L-Phe and AA4 = D-Hpg (43) and -2 Da product upon reaction with OxyB (44).

HR-MS/MS for starting material AA2 =4-NH2-L-Phe and AA4=D-Hpg 43

\begin{tabular}{|c|c|c|c|c|}
\hline $\begin{array}{c}\text { Charge } \\
\text { State }\end{array}$ & $\begin{array}{c}\text { Calculated } \\
\mathbf{m} / \mathbf{z}\end{array}$ & $\begin{array}{c}\text { Observed } \\
\mathbf{m} / \mathbf{z}\end{array}$ & $\Delta$ ppm & Sequence \\
\hline $\mathbf{b}_{2}{ }^{+1}$ & 291.1709 & 291.1674 & 12 & MeLeu-Tyr \\
\hline $\mathbf{b}_{3}{ }^{+1}$ & 405.2138 & 405.216 & 5.5 & MeLeu-Tyr-Asn \\
\hline $\mathbf{b}_{4}^{+1}$ & 554.2644 & 554.2615 & 5.3 & MeLeu-Tyr-Asn-Hpg \\
\hline $\mathrm{bs}^{+1}$ & 703.3092 & 703.306 & 4.5 & MeLeu-Tyr-Asn-Hpg-Hpg \\
\hline $\mathrm{b}_{6}{ }^{+1}$ & 865.3885 & 865.3865 & 2.2 & MeLeu-Tyr-Asn-Hpg-Hpg-Asn \\
\hline $\mathbf{b}_{7}^{+1}$ & 1028.4518 & 1028.4454 & 6.1 & MeLeu-Tyr-Asn-Hpg-Hpg- $4 \mathrm{NH}_{2}$ Phe-Tyr \\
\hline $\mathrm{y}_{3}{ }^{+1}$ & 385.2229 & 385.2215 & 3.4 & $4 \mathrm{NH}_{2}$ Phe-Tyr-propyl \\
\hline $\mathbf{y}_{4}^{+1}$ & 534.2705 & 534.2761 & 10.5 & Hpg-4NH${ }_{2}$ Phe-Tyr-propyl \\
\hline $\mathbf{y}_{5}^{+1}$ & 683.3182 & 683.3166 & 2.3 & Hpg-Hpg-4NH 2 Phe-Tyr-propyl \\
\hline $\mathbf{y}_{7}^{+1}$ & 960.4245 & 960.4114 & 13.5 & Tyr-Asn-Hpg-Hpg-4NH${ }_{2}$ Phe-Tyr-propyl \\
\hline
\end{tabular}

HR-MS/MS for product 44

\begin{tabular}{|c|c|c|c|c|}
\hline $\begin{array}{c}\text { Charge } \\
\text { State }\end{array}$ & $\begin{array}{c}\text { Calculated } \\
\mathbf{m} / \mathbf{z}\end{array}$ & $\begin{array}{c}\text { Observed } \\
\mathbf{m} / \mathbf{z} \\
\end{array}$ & $\Delta$ ppm & Sequence \\
\hline $\mathbf{b}_{2}{ }^{+1}$ & 291.1709 & 291.1693 & 5.3 & MeLeu-Tyr \\
\hline $\mathbf{b}_{3}{ }^{+1}$ & 405.2138 & 405.2159 & 5.3 & MeLeu-Tyr-Asn \\
\hline $\mathbf{b}_{6}{ }^{+1}$ & 863.3728 & 863.3725 & 0.2 & MeLeu-Tyr-Asn-Hpg ${ }_{m}-H p g-4 \mathrm{NH}_{2} \mathrm{Phe}_{\mathrm{m}}$ \\
\hline $\mathbf{b}_{7}^{+1}$ & 1026.4361 & 1026.4337 & 2.3 & MeLeu-Tyr-Asn-Hpg ${ }_{m}-\mathrm{Hpg}-4 \mathrm{NH}_{2} \mathrm{Phe}_{\mathrm{m}}-\mathrm{Tyr}$ \\
\hline $\mathrm{y}_{6}{ }^{+1}$ & 795.3455 & 795.3484 & 3.7 & Asn-Hpg ${ }_{m}-H p g-4 \mathrm{NH}_{2} \mathrm{Phe}_{\mathrm{m}}$-Tyr-propyl \\
\hline $\mathbf{y}_{7}^{+1}$ & 958.4088 & 958.401 & 8 & Tyr-Asn-Hpg ${ }_{m}-H p g-4 \mathrm{NH}_{2} \mathrm{Phe}_{\mathrm{m}}$-Tyr-propyl \\
\hline
\end{tabular}


Table S40. HR-MS/MS data for starting material AA2 $=4-\mathrm{NH}_{2}-\mathrm{L}-\mathrm{Phe}$ and AA4 $=$ ortho- ${ }^{2} \mathrm{H}_{2}-\mathrm{D}-$

Hpg and -3 Da product upon reaction with OxyB (45).

$H R-M S / M S$ for starting material AA2 $=4-\mathrm{NH}_{2}-\mathrm{L}-\mathrm{Phe}$ and $\mathrm{AA4}=$ ortho- ${ }^{2} \mathrm{H}_{2}-\mathrm{D}-\mathrm{Hpg}$

\begin{tabular}{|c|c|c|c|c|}
\hline $\begin{array}{c}\text { Charge } \\
\text { State }\end{array}$ & $\begin{array}{c}\text { Calculated } \\
\mathrm{m} / \mathrm{z}\end{array}$ & $\begin{array}{c}\text { Observed } \\
\mathbf{m} / \mathbf{z}\end{array}$ & $\Delta \mathbf{p p m}$ & Sequence \\
\hline $\mathbf{b}_{2}{ }^{+1}$ & 291.1709 & 291.1635 & 25.1 & MeLeu-Tyr \\
\hline$b_{3}{ }^{+1}$ & 405.2138 & 405.2126 & 2.7 & MeLeu-Tyr-Asn \\
\hline $\mathbf{b}_{4}^{+1}$ & 556.274 & 556.2704 & 6.4 & MeLeu-Tyr-Asn- ${ }^{2} \mathrm{H}_{2} \mathrm{Hpg}$ \\
\hline$b_{5}+1$ & 705.3217 & 705.3158 & 8.3 & MeLeu-Tyr-Asn- ${ }^{2} \mathrm{H}_{2} \mathrm{Hpg}-\mathrm{Hpg}$ \\
\hline $\mathbf{b}_{7}^{+1}$ & 1030.4642 & 1030.4546 & 9.2 & MeLeu-Tyr-Asn- ${ }^{2} \mathrm{H}_{2} \mathrm{Hpg}-\mathrm{Hpg}-4 \mathrm{NH}_{2} \mathrm{Phe}-\mathrm{Tyr}$ \\
\hline $\mathrm{y}_{3}{ }^{+1}$ & 385.2229 & 385.2205 & 6.2 & 4NH${ }_{2}$ Phe-Tyr-propyl \\
\hline$y_{4}^{+1}$ & 534.2705 & 534.2688 & 3.1 & Hpg-4NH ${ }_{2}$ Phe-Tyr-propyl \\
\hline$y_{5}+1$ & 685.3308 & 685.3296 & 1.6 & ${ }^{2} \mathrm{H}_{2} \mathrm{Hpg}$-Hpg-4 $\mathrm{NH}_{2}$ Phe-Tyr-propyl \\
\hline $\mathrm{y}_{7}^{+1}$ & 962.437 & 962.4326 & 4.5 & Tyr-Asn- ${ }^{2} \mathrm{H} 2 \mathrm{Hpg}-\mathrm{Hpg}-4 \mathrm{NH}_{2}$ Phe-Tyr-propyl \\
\hline
\end{tabular}

HR-MS/MS for product 45

\begin{tabular}{|c|c|c|c|c|}
\hline $\begin{array}{c}\text { Charge } \\
\text { State }\end{array}$ & $\begin{array}{c}\text { Calculated } \\
\mathrm{m} / \mathrm{z}\end{array}$ & $\begin{array}{c}\text { Observed } \\
\mathbf{m} / \mathbf{z}\end{array}$ & $\Delta$ ppm & Sequence \\
\hline $\mathbf{b}_{2}^{+1}$ & 291.1709 & 291.166 & 16.7 & MeLeu-Tyr \\
\hline $\mathbf{b}_{3}{ }^{+1}$ & 405.2138 & 405.2109 & 7 & MeLeu-Tyr-Asn \\
\hline $\mathbf{b}^{+1}$ & 864.3791 & 864.3741 & 5.6 & MeLeu-Tyr-Asn- ${ }^{2} \mathrm{H}_{2} \mathrm{Hpg}_{\mathrm{m}}-\mathrm{Hpg}-4 \mathrm{NH}_{2} \mathrm{Phe}_{\mathrm{m}}$ \\
\hline $\mathbf{b}_{7}^{+1}$ & 1027.4424 & 1027.4359 & 6.3 & MeLeu-Tyr-Asn- ${ }^{2} \mathrm{H}_{2} \mathrm{Hpg}$ m-Hpg- $4 \mathrm{NH}_{2} \mathrm{Phe}_{\mathrm{m}}-\mathrm{Tyr}$ \\
\hline $\mathrm{y}_{6}{ }^{+1}$ & 796.3518 & 796.3467 & 6.3 & Asn- ${ }^{2} \mathrm{H}_{2} \mathrm{Hpg}_{\mathrm{m}}-\mathrm{Hpg}-4 \mathrm{NH}_{2} \mathrm{Phe}_{\mathrm{m}}$-Tyr-propyl \\
\hline $\mathbf{y}_{7}^{+1}$ & 959.4151 & 959.4101 & 5.1 & Tyr-Asn- ${ }^{2} \mathrm{H}_{2} \mathrm{Hpg}_{\mathrm{m}}-\mathrm{Hpg}-4 \mathrm{NH}_{2} \mathrm{Phe}_{\mathrm{m}}$-Tyr-propyl \\
\hline
\end{tabular}


Table S41. HR-MS/MS data for starting material AA2 = 4-NH2-L-Phe and AA4 = D-PhGly (46) and -2 Da product upon reaction with OxyB (47).

$H R-M S / M S$ for starting material $A A 2=4-N_{2}-L-P h e$ and $A A 4=D-P h G l y 46$

\begin{tabular}{ccccl}
\hline $\begin{array}{c}\text { Charge } \\
\text { State }\end{array}$ & $\begin{array}{c}\text { Calculated } \\
\mathbf{m} / \mathbf{z}\end{array}$ & $\begin{array}{c}\text { Observed } \\
\mathbf{m} / \mathbf{z}\end{array}$ & \multicolumn{1}{|c|}{ (ppm } & \multicolumn{1}{c}{ Sequence } \\
\hline $\mathbf{b}_{2}{ }^{+1}$ & 291.1709 & 291.1674 & 12 & MeLeu-Tyr \\
$\mathbf{b}_{3}{ }^{+1}$ & 405.2138 & 405.2137 & 0.2 & MeLeu-Tyr-Asn \\
$\mathbf{b}_{4}{ }^{+1}$ & 538.2666 & 538.2656 & 1.8 & MeLeu-Tyr-Asn-PhGly \\
$\mathbf{b}_{5}{ }^{+1}$ & 687.3142 & 687.3092 & 7.2 & MeLeu-Tyr-Asn-PhGly-Hpg \\
$\mathbf{b}_{6}{ }^{+1}$ & 849.3836 & 849.3869 & 3.9 & MeLeu-Tyr-Asn-PhGly-Hpg-4NH2Phe \\
$\mathbf{b}_{7}{ }^{+1}$ & 1012.4569 & 1012.4497 & 7.1 & MeLeu-Tyr-Asn-PhGly-Hpg-4NH2Phe-Tyr \\
\hline $\mathbf{y}_{3}{ }^{+1}$ & 385.2229 & 385.2215 & 9.3 & 4NH2Phe-Tyr-propyl \\
$\mathbf{y}_{4}{ }^{+1}$ & 534.2705 & 534.2694 & 2 & Hpg-4NH2Phe-Tyr-propyl \\
$\mathbf{y}_{5}{ }^{+1}$ & 667.3233 & 667.3137 & 14.2 & PhGly-Hpg-4NH2Phe-Tyr-propyl \\
$\mathbf{y}_{6}{ }^{+1}$ & 781.3663 & 781.3621 & 5.2 & Asn-PhGly-Hpg-4NH2Phe-Tyr-propyl \\
$\mathbf{y}_{7}{ }^{+1}$ & 944.4296 & 944.4274 & 2.3 & 4MePhe-Asn-PhGly-Hpg-4NH2Phe-Tyr-propyl \\
\hline
\end{tabular}

HR-MS/MS for product 47

\begin{tabular}{|c|c|c|c|c|}
\hline $\begin{array}{c}\text { Charge } \\
\text { State } \\
\end{array}$ & $\begin{array}{c}\text { Calculated } \\
\mathbf{m} / \mathbf{z}\end{array}$ & $\begin{array}{c}\text { Observed } \\
\mathbf{m} / \mathbf{z} \\
\end{array}$ & $\Delta$ ppm & Sequence \\
\hline $\mathbf{b}_{2}^{+1}$ & 291.1709 & 291.1691 & 6 & MeLeu-Tyr \\
\hline $\mathbf{b}_{3}{ }^{+1}$ & 405.2138 & 405.2162 & 5.9 & MeLeu-Tyr-Asn \\
\hline $\mathbf{b}_{4}^{+1}$ & 538.2666 & 538.2682 & 3 & MeLeu-Tyr-Asn-PhGly \\
\hline $\mathbf{b}_{6}{ }^{+1}$ & 847.3779 & 847.3812 & 4 & MeLeu-Tyr-Asn-PhGly-Hpg ${ }_{m}-4 \mathrm{NH}_{2} \mathrm{Phe}_{\mathrm{m}}$ \\
\hline $\mathrm{y}_{5}^{+1}$ & 665.3077 & 665.3038 & 5.8 & Asn-PhGly-Hpg ${ }_{m}-4 \mathrm{NH}_{2} \mathrm{Phe}_{\mathrm{m}}$-Tyr-propyl \\
\hline
\end{tabular}


Table S42. HR-MS data for substrates and products of OxyB, OxyA and OxyC enzymatic reactions. Sequence of peptides shown is (D/L-Dpg)-AA2-(D-Hpg)-AA4-(L-Ans5)-(D-Tyr6)-( $N$ Me-D-Leu7).

\begin{tabular}{llllllll}
\hline \hline Compound & \multirow{2}{*}{ AA1 } & \multirow{2}{*}{ AA2 } & AA4 & Charge State & $\begin{array}{l}\text { Calculated } \\
\text { mass }\end{array}$ & $\begin{array}{l}\text { Observed } \\
\text { mass }\end{array}$ & \multirow{2}{*}{ sppm } \\
\hline \hline $\mathbf{4 8}$ & Dpg & L-HomoTyr & D-Hpg & {$[\mathrm{M}+\mathrm{H}]^{+}$} & 1138.4647 & 1138.463 & 1.4 \\
-2 pdt of 48 & Dpg & L-HomoTyr & D-Hpg & {$[\mathrm{M}+\mathrm{H}]^{+}$} & 1136.4491 & 1136.44933 & 0.2 \\
$\mathbf{4 9}$ & Dpg & L-HomoTyr & D-Hpg & {$[\mathrm{M}+\mathrm{H}]^{+}$} & 1134.4334 & 1134.43179 & 1.4 \\
\hline $\mathbf{5 0}$ & Dpg & 3-Cl-HomoTyr & D-Hpg & {$[\mathrm{M}+\mathrm{H}+3 \mathrm{Na}]^{+}$} & 1238.3715 & 1238.3535 & 14.5 \\
-2 pdt of 50 & Dpg & 3-Cl-HomoTyr & D-Hpg & {$[\mathrm{M}+\mathrm{H}+3 \mathrm{Na}]^{+}$} & 1236.35591 & 1236.34339 & 10.1 \\
-4 pdt of 50 & Dpg & 3-Cl-HomoTyr & D-Hpg & {$[\mathrm{M}+\mathrm{H}+3 \mathrm{Na}]^{+}$} & 1234.3402 & 1234.34881 & 6.9 \\
$\mathbf{5 1}$ & Dpg & 3-Cl-HomoTyr & D-Hpg & {$[\mathrm{M}+\mathrm{H}+3 \mathrm{Na}]^{+}$} & 1232.32461 & 1232.33977 & 12.3 \\
\hline
\end{tabular}




\section{References}

(1) Forneris, C. C.; Ozturk, S.; Gibson, M. I.; Sorensen, E. J.; Seyedsayamdost, M. R. In Vitro Reconstitution of OxyA Enzymatic Activity Clarifies Late Steps in Vancomycin Biosynthesis. ACS Chem. Biol. 2017, 12, 2248-2253.

(2) Forneris, C. C.; Seyedsayamdost, M. R. In Vitro Reconstitution of OxyC Activity Enables Total Chemoenzymatic Syntheses of Vancomycin Aglycone Variants. Angew. Chemie Int. Ed. 2018, 57, 8048-8052.

(3) Haslinger, K.; Maximowitsch, E.; Brieke, C.; Koch, A.; Cryle, M. J. Cytochrome P450 OxyBtei Catalyzes the First Phenolic Coupling Step in Teicoplanin Biosynthesis. ChemBioChem 2014, 15, 2719-2728.

(4) Brieke, C.; Kratzig, V.; Peschke, M.; Cryle, M. J. Facile Synthetic Access to Glycopeptide Antibiotic Precursor Peptides for the Investigation of Cytochrome P450 Action in Glycopeptide Antibiotic Biosynthesis. In Nonribosomal Peptide and Polyketide Biosynthesis: Methods and Protocols; Evans, B. S., Ed.; Springer New York: New York, NY, 2016; pp 85-102.

(5) Woithe, K.; Geib, N.; Zerbe, K.; Dong, B. L.; Heck, M.; Fournier-Rousset, S.; Meyer, O.; Vitali, F.; Matoba, N.; Abou-Hadeed, K.; Robinson, J. A. Oxidative Phenol Coupling Reactions Catalyzed by OxyB: A Cytochrome P450 from the Vancomycin Producing Organism. Implications for Vancomycin Biosynthesis. J. Am. Chem. Soc. 2007, 129, 6887-6895.

(6) Geib, N.; Weber, T.; Wörtz, T.; Zerbe, K.; Wohlleben, W.; Robinson, J. A. Genome Mining in Amycolatopsis Balhimycina for Ferredoxins Capable of Supporting Cytochrome P450 Enzymes Involved in Glycopeptide Antibiotic Biosynthesis. FEMS Microbiol. Lett. 2010, 306, 45-53.

(7) Pearce, C. M.; Williams, D. H. Complete Assignment of the 13C NMR Spectrum of Vancomycin. J. Chem. Soc. Perkin Trans 2 1995, 153-157.

(8) Cochrane, J. R.; White, J. M.; Wille, U.; Hutton, C. A. Total Synthesis of Mycocyclosin. Org. Lett. 2012, 14, 2402-2405.

(9) Kulanthaivel, P.; Kreuzman, A. J.; Strege, M. A.; Belvo, M. D.; Smitka, T. A.; Clemens, M.; Swartling, J. R.; Minton, K. L.; Zheng, F.; Angleton, E. L.; Mullen, D.; Jungheim, L. N.; Klimkowski, V. J.; Nicas, T. I.; Thompson, R. C.; Peng, S. Novel Lipoglycopeptides as Inhibitors of Bacterial Signal Peptidase I. J. Biol. Chem. 2004, 279, 36250-36258. 